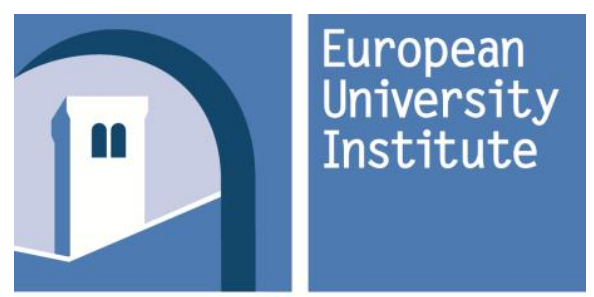

DEPARTMENT

OF LAW

\title{
Citizenship, Crime and Community in the European Union
}

\author{
Stephen Coutts
}

Thesis submitted for assessment with a view to obtaining the degree of Doctor of Laws of the European University Institute

Florence, 6 November, 2015 



\title{
European University Institute
}

\section{Department of Law}

Citizenship, Crime and Community in the European Union

\author{
Stephen Coutts
}

Thesis submitted for assessment with a view to obtaining the degree of Doctor of Laws of the European University Institute

\section{Examining Board}

Professor Loïc Azoulai, EUI (Supervisor)

Professor Marise Cremona, EUI

Professor Valsamis Mitsilegas, Queen Mary University, London

Professor Niamh Níc Shuibhne, University of Edinburgh

(C) Stephen Coutts, 2015

No part of this thesis may be copied, reproduced or transmitted without prior permission of the author 



\section{Thesis Summary:}

The aim of this thesis is to analyse the extent to which criminal law can contribute towards our understanding of Union citizenship and of the political community of the Union. In carrying out this task it adopts a particular perspective on both criminal law and Union citizenship. Firstly, it adopts the criminal law theory developed by RA Duff, premised on the notions of citizenship and community; crimes are viewed as public wrongs, committed against the community. Individuals are held responsible as citizens and are called to account before the community. Secondly, it adopts a particular account of Union citizenship based on a distinction between transnational dimensions and supranational dimensions. The transnational dimension is then broken into two sub-dimensions based on the concepts of social integration and autonomy or a space of free movement.

The role of criminal law in these dimensions of Union Citizenship is analysed in the main body of the thesis. Two chapters consider the role of criminal law in social integration in the context of the acquisition of residence rights and the serving of sentences. Two chapters consider the parallels between the autonomy of Union citizens that results in a single space of movement, and the area of justice as it is constructed through the European Arrest Warrant and the operation of a transnational ne bis in idem principle. A final substantive chapter details the competence of the Union to adopt legislation criminalising certain conduct and the extent to which this can be said to contribute to the formation of a community at a supranational level. A conclusion brings together the findings of the thesis in relation to Union citizenship and considers the implications for the structure of the political community in the Union. It is suggested the national remains the main site for communities in the Union. However, transnational processes associated with Union citizenship trigger the emergence of certain supranational norms and ultimately a composite, complementary supranational community. 



\section{Acknowledgments}

While the writing of a $\mathrm{PhD}$ thesis is often said to be a lonely process, my own experience has been anything but. I have been blessed with a rich and stimulating academic environment and a group of friends and colleagues both in Florence and elsewhere without the support of whom this thesis would never have been produced.

The EUI is an exceptional place. Perched on the hills over the city of Florence, it is hard to imagine a more ideal place for pursuing post-graduate research and for exploring the complex, inspiring, fascinating and at times infuriating phenomenon that is the European Union. My thanks to the professors in both the Department of Law and elsewhere who gave their time and considerable expertise in discussions on the work contained in this thesis and the opportunity to be involved in events and projects that broadened and enriched my academic interests. Above all thanks to my supervisor, Professor Azoulai, without whose support this thesis would never have been written. His promptings and discussions fostered an intellectual curiosity and an interest in ideas that I hope is apparent in this thesis.

My thanks also to an exceptional group of friends who proved that there is more to life in Florence than the Uffizi, the Ponte Vecchio and David and who proved there is more to the EUI than the library, conferences and research. To Rebecca, Kaisha, Jacob, Tiago, Lucilla, Berenika and Boris amongst others. However, this thesis was not the sole product of the EUI or Florence. My thanks also to colleagues and friends in UC Berkeley and Dublin Citiy University.

Finally, I have been blessed with family and friends from home. To my long-suffering family, tactfully avoiding the question of when I will final leave college; Mum, Dad, Sharon and Yvonne. To my second family, forged in the crucible of Law and French. And to Cian, whose unfailing support, encouragement and patience have been indispensable in this and other

endeavours. 



\section{Table of Contents}

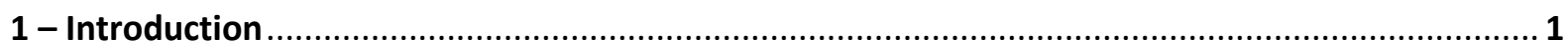

Citizenship, Crime and Community - The Theory of RA Duff....................................................... 2

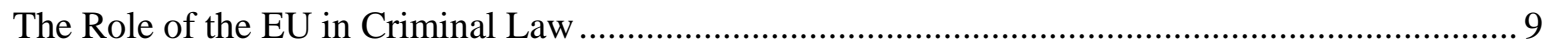

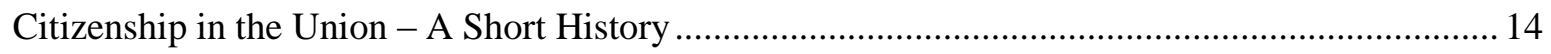

Conclusion - Method and Framework of Analysis......................................................................... 22

2- Union Citizenship: Between Transnational and Supranational ................................................ 25

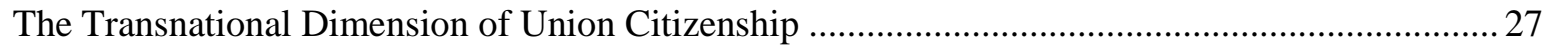

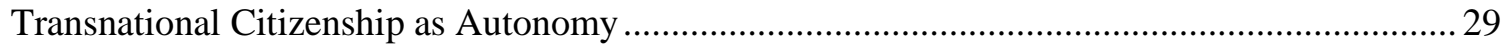

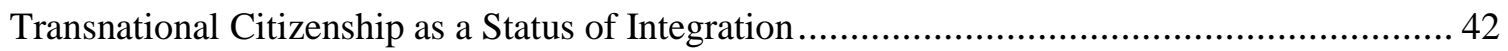

Union Citizenship as a Transnational Status between Autonomy and Integration ........................... 49

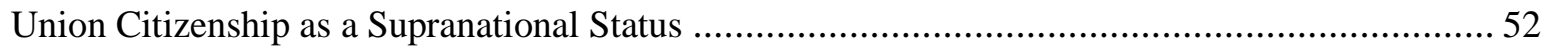

The Establishment of a Supranational Status: Zambrano and Rottmann ............................. 53

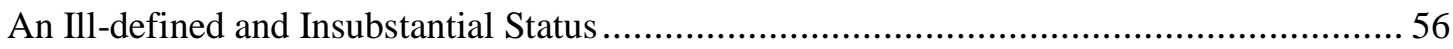

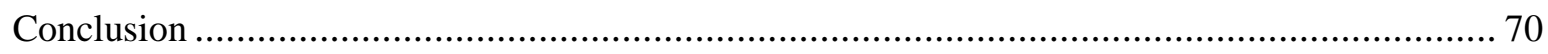

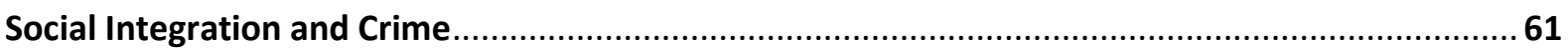

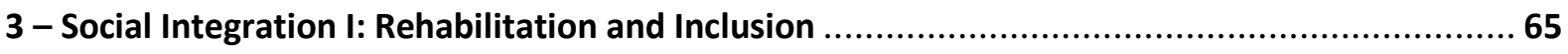

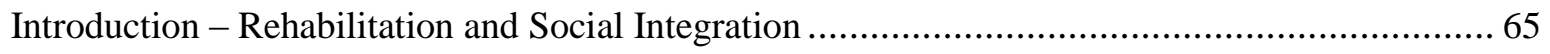

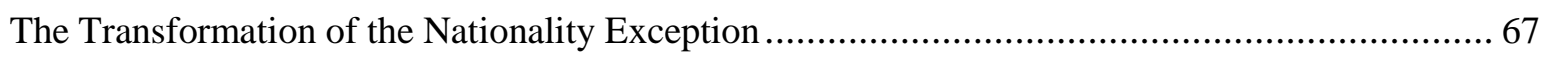

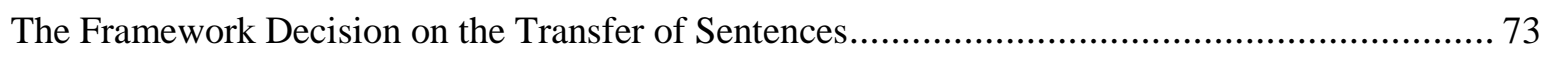

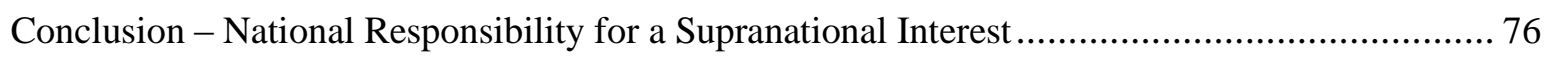

4 - Social Integration II: Wrongdoing and a Supranational Duty of Respect.............................. 81

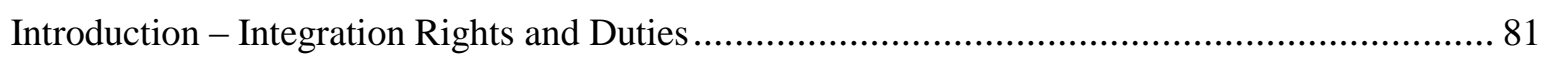

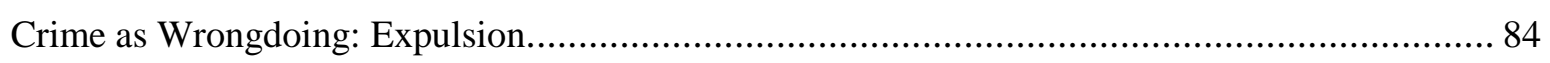

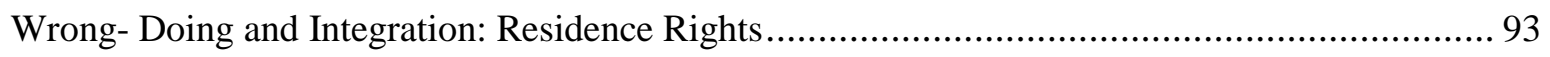

Conclusion - A Supranational Duty of Respect towards National Communities ......................... 97

An Area of Justice - Shared Enforcement and Shared Recognition of National Wrongs ............... 103 


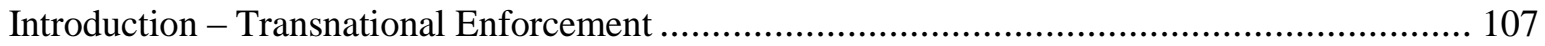

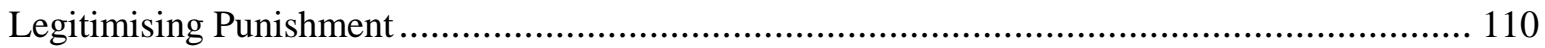

Legitimising Shared Enforcement I - Shared Citizenship.................................................. 112

Legitimising Shared Enforcement II - Shared Wrongs......................................................... 117

Legitimising Shared Enforcement III - Shared Rights ......................................................... 124

Conclusion - Transnational Enforcement in a Supranational Space ...................................... 133

6 - An Area of Justice II: A Transnational Ne Bis in Idem Principle ......................................... 135

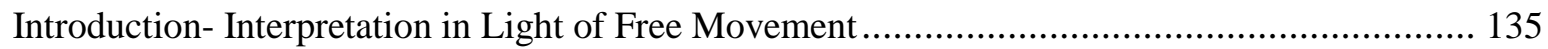

Interpretation of Finality in Light of Free Movement - A Single Status ................................... 141

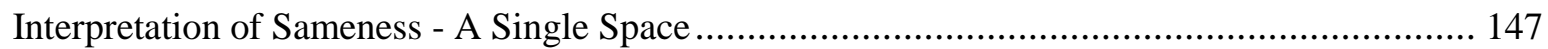

Conclusion - A Multi-Levelled Calling to Account ........................................................... 150

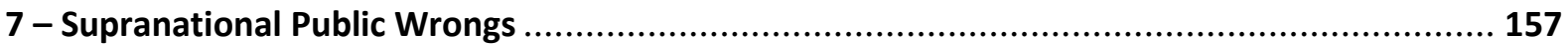

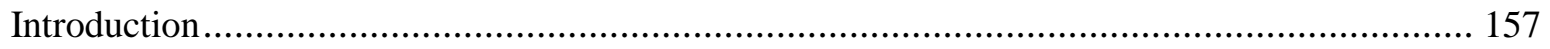

Structural Limitations on an EU Supranational Community …........................................... 159

Articulation of Public Wrongs - Limited Scope for EU Criminalisation ........................... 159

Communication of Public Wrongs - EU Criminal Law as Multi-Levelled ........................ 164

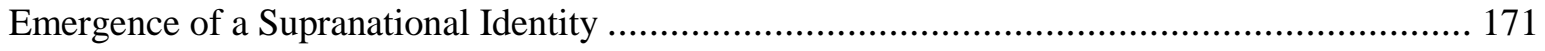

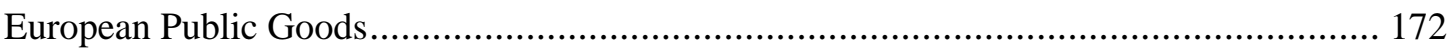

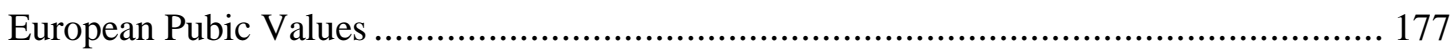

Supranational Wrongs and Transnational Processes.............................................................. 181

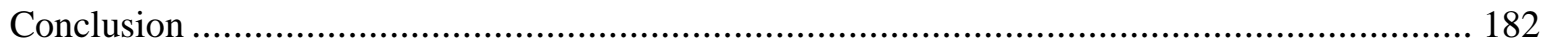

Conclusion - Union Citizenship, Criminal Law and the Restructuring of Community ................. 187

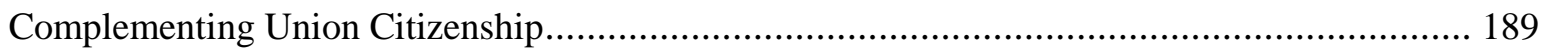

The Restructuring of Political Community in the European Union......................................... 193

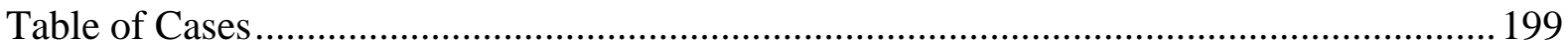

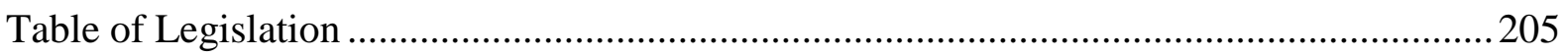

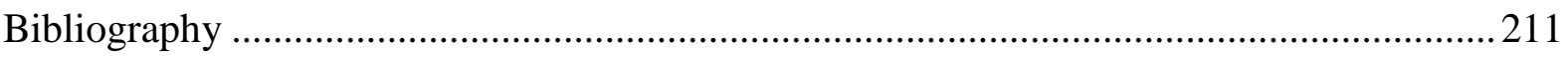




\title{
Chapter 1
}

\section{Introduction:}

\section{Citizenship, Crime and Community in the European Union}

\author{
Introduction
}

Criminal law is concerned with responsibilities. However, responsibility is a relational concept; we are responsible to someone for something. That relationship is found in the notion of citizenship; we are responsible to each other as citizens of the same political community. And we are responsible for our actions that offend against the norms, values and interests of that community. The criminal law therefore reflects aspects of citizenship and political community. It involves responsibilities, and indeed corresponding rights and a moral relationship between co-members of the community. Through the criminal law the community lays down the norms that govern relations between its members and expresses the values inherent to that particular community and through this expressive dimension it can be said to contribute to the formation of the identity of the community.

Citizenship and community are useful as means of explaining criminal law. However, the converse is also true; a communitarian account of the criminal law can be a useful means of exploring hitherto unexamined aspects of citizenship and the community and can help complement and enrich our understanding of these concepts. This is precisely the approach adopted in this thesis concerning Union citizenship. An examination of Union citizenship in light of a communitarian account of the criminal law can, it is suggested, provide important insights concerning Union citizenship and the political community of the Union.

This chapter serves as a general introduction to the subjects of this thesis, EU criminal law, Union citizenship and the theory of RA Duff that links the concepts of citizenship and criminal law and which provides the methodological framework for the remainder of this thesis. The first part presents Duff's theory based on an understanding of crimes as public 
wrongs and as reflecting responsibilities by individuals to other individuals qua citizens under the common values and norms of their particular community. The second part briefly introduces the role of the EU in criminal law. The third part provides a history of Union citizenship while outlining some of its main features. A conclusion provides an outline of the remainder of the thesis.

\section{Citizenship, Crime and Community The Theory of RA Duff}

\section{Crimes as Public Wrongs}

The criminal law prohibits certain conduct. Through it the state claims authority to declare certain norms of conduct and to insist on their respect. More than any other area of law the criminal law carries the implication of “'ought not to do' and enforces these prohibitions through the use of physical force. It is the censure contained in the criminal law and the exercise of physical force to enforce it that marks out its special social significance ${ }^{1}$ and calls for heightened justification. These simple statements immediately raise a number of questions of the criminal law and in particular the legitimacy of the polity to declare and enforce such norms on supposedly free individuals. To put the question another way: what conduct can the community legitimately require individuals to refrain from? ${ }^{2}$ A classic utilitarian perspective, rooted in the rationalism of the Enlightenment and particularly influential in Anglo-American criminal law, ${ }^{3}$ would justify the imposition of criminal liability according to the harm principle, most famously articulated by Mill according to which 'the only purpose for which power can be rightfully exercised over any member of a civilised community, against his will, is to prevent harm to others. ${ }^{4}$ Feinberg has provided the most comprehensive restatement of such a liberal conception of the criminal law through

\footnotetext{
${ }^{1}$ Andrew Ashworth, Principles of Criminal Law (2 edn, Claredon Press 1995) 1.

${ }^{2}$ There are of course some crimes of omission, requiring not that an individual refrain from a particular action but take positive steps. However, this category is relatively minor, particularly in the Anglo-American tradition, and only operates under certain circumstances, normally when a pre-existing relationship of a certain quality exists establishing a particular duty to act. See Alan Norrie, Crime, Reason and History: A Critical Introduction to Criminal Law (1 edn, Weidenfeld \& Nicolson 1993) ch 6.

${ }^{3}$ Ibid ch 1.

${ }^{4}$ John Stewart Mill, On Liberty and Other Essays (first published 1859 OUP 1991) 15. For a discussion of Mill's, but also other versions of the harm principle, see RA Duff, Answering for Crime: Responsability and Liability in the Criminal Law (Hart 2007) 123 ff. For a modern restatement of Mill's harm principle see Joel Feinberg, The Moral Limits of the Criminal Law: Harm to Others, vol I (OUP 1984).
} 
a detailed elaboration of the harm principle based around the concept of a 'setback to interests'.5 This he has supplemented with an 'offense principle', with very limited application, ${ }^{6}$ and a rejection of both legal paternalism ${ }^{7}$ and legal moralism as incompatible with a liberal philosophy. ${ }^{8}$

However, while the harm principle can be a useful starting point for determining which actions are to be labelled crimes it is not sufficient in itself to capture what are commonly understood to be crimes. Instead, RA Duff, amongst others, has proposed applying a moral rather than utilitarian approach to criminal law, defining crimes as public wrongs. ${ }^{9}$

Duff has pointed out that the harm principle is both under and over inclusive. It is underinclusive in that it fails to capture the moral, in addition to the material or physical, nature of a criminal attack. ${ }^{10}$ Thus, the violation of personal privacy and space, in addition to simply deprivation of material goods, occasioned by burglary is not captured by all but the most wide ranging harm principle. Equally we consider rape to be criminal not simply by virtue of the physical and emotional harm caused to the victim but also by its blatant disregard for the respect due him or her as a morally autonomous individual. Furthermore, it is difficult to reconcile the harm principle with situations where individuals willingly submit to what might otherwise be considered a harmful situation such as polygamy and or sadomasochism. ${ }^{11}$ The criminal law reserves the right to criminalise conduct regardless of whether the 'victim' considers it harmful. It is true that these situations might be captured by a sufficiently broad definition of 'harm', however to do so would stretch the underlying concept of the harm principle and ultimately perhaps leave it so broad as to be

\footnotetext{
${ }^{5}$ Feinberg (n 4).

${ }^{6}$ Joel Feinberg, The Moral Limits of the Criminal Law: Offense to Others, vol II (OUP 1985).

${ }^{7}$ Joel Feinberg, The Moral Limits of the Criminal Law: Harm to Self, vol III (OUP 1986).

${ }^{8}$ Joel Feinberg, The Moral Limits of the Criminal Law: Harmless Wrongdoing, vol IV (OUP 1988).

9 Most famously articulated by Lord Devlin in response to the Wolfenden report advocating the decriminalisation of homosexual acts in the UK amongst other issues. For an account and HLA Hart's response see HLA Hart, Law, Liberty and Morality (OUP 1962). For one of the more prominent moral theories of criminalization see Michael Moore, Placing Blame: A Theory of Criminal Law (OUP 1997).

${ }^{10}$ Although it should be noted that Feinberg's formulation of the harm principle only prohibits wrongful harms ie harms that violate an individual's rights. However, it is unlikely that Feinberg's notion of a violation of a right properly articulates Duff's conception of a moral wrong. That conception is closer to the more clearly moralist position of Moore, based on emotions and sense of violation. See Moore (n 9).

${ }^{11}$ Duff gives the example of the famous UK House of Lords decision of $R v$ Brown [1994] 1 AC 212 involving consensual sadomasochistic sexual encounters between groups of adult men.
} 
meaningless. ${ }^{12}$ It would certainly fail in its stated purpose of providing clear guidance on what may or may not be criminalised by the state.

The principle is also over inclusive in two ways. Firstly, it would criminalise harm that we would normally consider private and outside the purview of the criminal law, such as emotional or even financial harm caused by the breakdown of a relationship. Secondly, a proper application of the harm principle requires not simply the criminalisation of directly harmful conduct, but criminalisation of conduct that poses a mere risk of harm, such as reckless driving or failure to follow safety rules in a high risk industry. Therefore for this reason also 'it is hard to see how [the harm principle] can set tight or determinate limits on the scope of the criminal law. ${ }^{, 13}$

Instead of a justification based on the harm principle, Duff proposes a broader moral basis for the criminal law; crimes as wrongs. ${ }^{14}$ Unlike torts, the remedy of which is to undo the harm caused, crimes are wrongs and conviction of a crime involves punishment and condemnation. ${ }^{15}$ It involves a retributive element independent from deterrence or restoration. The harm principle can still play a role in identifying at least some, if not all, of those criminal wrongs, particularly as a constraint on a liberal criminal law. However, even if harm is used as a criterion for identifying a wrong, in the eyes of the criminal law it cannot be disassociated from its wrongful character. ${ }^{16}$ It should be noted that defining crimes as wrongs necessarily abandons the pursuit of any master principle capable of identifying the content of the criminal law once and for all. The concept of a wrong is not a closed or fixed category and there is no 'single concept or value that will capture the essence of crime, or the essential characteristic in virtue of which crimes are properly punished...[R]ather we should resist this desire in favour of a pluralism that recognises a diversity of reasons for

\footnotetext{
${ }^{12}$ With the further result that it would cease 'to set substantial independent constraints on the scope of criminal law', Duff (n 4) 135.

13 Ibid 137.

${ }^{14}$ It should be pointed out that Feinberg also considers the criminal law to contain a moral element, in his version of the harm principle it is wrongful harms (ie those setbacks to interest that violate another persons rights) that constitute by far the largest categories of acts that can be legitimately criminalised. See Feinberg, The Moral Limits of the Criminal Law: Harm to Others (n 4) ch 3.

${ }^{15}$ RA Duff, Theories of Criminal Law (The Stanford Encyclopedia of Philosophy (Summer 2013 Edition)). There are significant overlaps between tort and criminal law and in recent years their proper boundaries have become somewhat blurred but the conceptual distinction of torts as private harms and crimes as public wrongs remains. See also Joel Feinberg, 'The Expressive Function of Punishment' (1965) 49 The Monist 397, who considers the condemnatory aspect the defining characteristic of punishment.

16 'A moralised version of the Harm Principle does not aim to identify harms independently of the wrongs that generate them' Duff, Answering for Crime: Responsability and Liability in the Criminal Law (n 4) 139.
} 
criminalisation, matching the diversity of kinds of wrong which can legitimately be the criminal law's business. (emphasis in original) ${ }^{17}$ The criminal law and the wrongs it embodies can therefore vary from time to time and from place to place depending on the prevailing moral consensus of a particular society or community.

However, this is not to say that there are no limits on the criminal law. As mentioned above, in a liberal polity the harm principle can play some role in limiting the extent of the criminal law. Similarly, criminal law should be seen as a last resort or ultima ratio. Furthermore, there is an inherent limitation in the criminal law conceived as reflecting the values of a community. Crimes are not only wrongs, they are public wrongs and individuals can only be punished for wrongs that concern the broader community in a sufficiently serious manner to warrant retribution and condemnation. In the words of Blackstone, crimes 'are breach and violation of the public rights and duties, due to the whole community, considered as community, in its social aggregate capacity...[B]esides the injury done to individuals, [crimes] strike at the very being of society, which cannot possibly subsist, where actions of [that] sort are suffered to escape with impunity. In all cases the crime includes an injury: every public offence is also a private wrong, and somewhat more; it affects the individual and it likewise affects the community. ${ }^{, 18}$ This is not to say that criminal law should confine itself to acts that directly affect the public space or institutions such as public order offences or terrorism. Nor should we attempt to construe crimes against individuals as crimes directed against the social order per se. Duff rightly points out that to do so would 'distract us from the wrong done to the direct victims of such crimes, which surely should be central to our understanding of their criminal character. ${ }^{, 19}$ Rather than being wrongs done directly to the community, crimes are wrongs that concern the community for reasons of their seriousness and their affront to deeply held normative values of the community. They are wrongs in which the community shares. ${ }^{20}$

A number of characteristics of the criminal law and in particular the criminal procedure underline its public quality. Criminal prosecution is brought by a public body, a prosecutor or judge, in the name of the state, or even more tellingly 'the people'. Unlike in civil claims,

\footnotetext{
${ }^{17}$ Ibid 139. See also Anthony Duff, 'Theorizing Criminal Law: A 25th Anniversary Essay’ (2005) 25 OJLS 353.

${ }^{18}$ As quoted in Duff, Answering for Crime: Responsability and Liability in the Criminal Law (n 4) 52.

${ }^{19}$ RA Duff, Punishment, Communication and Community (OUP 2003) 61.

${ }^{20}$ Duff, Answering for Crime: Responsability and Liability in the Criminal Law (n 4) 52. See also RA Duff and SE Marshall, 'Criminalization and Sharing Wrongs' (1998) 11 CJLJ 7.
} 
the individual victim has a minimal role in both initiating and conducting the action. These procedural aspects reflect the underlying characteristic of the crime as a public wrong. It involves 'an authoritative, communal declaration of...wrongs' that, through the criminal trial, merit 'a public, communal response. ${ }^{21}$ The criminal trial is a means of publically calling the transgressing member of society to account for his actions, that he or she may possibly justify or excuse. Similarly, punishment can be seen, not simply or even primarily, as a means of deterrence, but in combining deterrence with a retributive and rehabilitative purpose, as a form of 'secular penance' towards the community. ${ }^{22}$

We therefore move away from a simple Austinian 'command and control' conception of the criminal law based on a relationship between sovereign and subjects to one in which individuals as members of a community have a relationship of responsibility to each other and the broader community by virtue of their membership. It is an inherently community based account of the criminal law. In the criminal trial the individual is called to account for his or her actions before the community. He or she is required to answer for his or her conduct deemed wrongful. The criminal law is a set of responsibilities on the basis of which we can be called to give an account. However, calling to account implies a relationship between the caller and the called that pre-exists the calling. ${ }^{23}$ Responsibility, and therefore criminal law itself, is a relational concept. A is responsible to $\mathrm{B}$ for $\mathrm{C}$. Moreover, the content of the responsibility of A to B depends on the type of relationship that exists between A and B. Given the public character of criminal law, it is in our capacities as citizens that we owe responsibilities to each other under the criminal law and may be called to account in the context of the community. 'As citizens who are both bound and protected by the values of our polity, we have both rights and responsibilities: we are answerable to each other for our conduct as citizens. ${ }^{24}$ Furthermore both the status of the offender and the victim as citizens explains and justifies the interest the community as a whole takes in the wrong; it renders a private wrong public and hence criminal. Even those wrongs that are directed at individuals 'count as "our" wrongs because they violate our public values and because we share them with the victim: our concern for the victim as our fellow citizen makes them our business. So

\footnotetext{
${ }^{21}$ Duff, Punishment, Communication and Community (n 19) 61.

${ }^{22}$ Ibid ch 3.

${ }^{23}$ RA Duff, 'Responsability, Citizenship and Criminal Law' in RA Duff and Stuart P Green (eds), Philosophical Foundations of Criminal Law (OUP 2011) 132.

${ }^{24}$ Duff, Answering for Crime: Responsability and Liability in the Criminal Law (n 4) 50.
} 
does our recognition of the wrongdoer as a fellow citizen: what is done by one of us, when it impinges on our shared values, is our business. ${ }^{25}$

Basing criminal law on citizenship raises two questions: firstly the position of non-citizens ${ }^{26}$ and secondly the effect that criminal activity, particularly persistent and egregious, on the citizenship status of offenders. ${ }^{27}$ Citizenship is an exclusive status whereas the criminal law both protects victims of crime and condemns offenders regardless of citizenship. ${ }^{28}$ While this may seem problematic it can be explained by conceiving of non-citizens as visitors to the polity who enjoy the status of guests. As guests they enjoy the protection but must also respect the normative values of the host society as expressed in its criminal law and must conduct themselves accordingly. ${ }^{29}$ With some consideration for the position of 'guests', Duff's theory can therefore accommodate non-citizens on the territory of the state. However, national criminal law sometimes claims jurisdiction beyond the territory of the state based on the nationality of the offender or victim. For Duff, such instances of extra-territorial claim only serve to highlight the essentially communitarian account of the criminal law he provides; we as a political community may claim an interest in both the wrongs our fellow citizens commit and suffer while abroad. ${ }^{30}$

A separate issue is the impact of serious breaches of the criminal law may have on the membership status of convicted citizens. Do such individuals by persistent and particularly serious transgressions of the normative values of the community, or even by direct attack on the interests or institutions of the state, forfeit either some of their rights of membership or indeed the status entirely? Recent controversy in the UK regarding the right to vote for prisoners, highlights the very real controversy that surrounds this question. ${ }^{31}$

A crime is therefore a wrong that properly concerns the community as a whole rather than simply the individual victim(s). It is an act that the community has recognised as wrongful in

\footnotetext{
${ }^{25}$ Duff, 'Responsability, Citizenship and Criminal Law' (n 23) 139.

${ }^{26}$ For an alternative view to Duff's see Alejandro Chehtman, 'Citizenshp v Territory: Explaining the Scope of the Criminal Law' (2010) 13 New Crim L Rev 427.

${ }^{27}$ Duff, 'Responsability, Citizenship and Criminal Law' (n 23) $141 \mathrm{ff}$.

${ }^{28}$ There are a small number of crimes that are citizenship specific, such as voter fraud or treason.

${ }^{29}$ Duff, Answering for Crime: Responsability and Liability in the Criminal Law (n 4) 142.

${ }^{30}$ Ibid 53-54. Note that Duff does not take a position on propriety of such a claim in any particular instance. His only point is that it is explainable in light of a community based account of the criminal law.

${ }^{31}$ Duff, 'Responsability, Citizenship and Criminal Law' (n 23) 143. See the ECHR judgment in Hirst v United Kingdom (2006) 42 EHRR 41.
} 
light of its shared values. The precise content of the criminal law will therefore necessarily vary between communities depending on their particular understandings of wrongfulness and the proper scope of matters of public concern. ${ }^{32}$ The criminal law declares or recognises certain wrongs deemed wrongful in light of the shared values and normative understandings of that community and prescribes the appropriate public reaction. It is therefore expressive or declarative: it declares certain actions to be wrongs, and attaches formal censure and condemnation to them. ${ }^{33}$ In a sense it is the 'common law' par excellence, which is not 'imposed on a people by a sovereign, which they must receive and obey as subjects. Rather it is the law of the community itself. It embodies the shared values and normative understandings of the community. It flows not from the will of a separate sovereign but from the traditions and practices of the community. ${ }^{, 34}$

Such a vision of criminal law, as a declaring certain acts to be wrongful in the eyes of the community and to be of concern to the community, presupposes a group of individuals sufficiently bound by ties of affection or affiliation and sharing a collective identity and political life in common. This is not to say that such a criminal law requires a community based on a thick, ethno-cultural identity. And while it does presuppose some element of community, it does not necessarily require a heavily communitarian perspective of the state, emphasising the needs of the community and the commonly defined 'good' over the interests of individuals. Indeed, the fundamental principles and tenets of modern criminal law developed out of a major period of reform originating in Enlightenment thinking and characterised by a radical liberalism. ${ }^{35}$ Duff proposes a liberal community as the context within which his theory would apply. ${ }^{36}$

For the most part this communitarian element of criminal law is unproblematic. Criminal law has developed principally in the context of the nation-state, a relatively homogenous unit

\footnotetext{
${ }^{32}$ Duff, Punishment, Communication and Community (n 19) 63.

${ }^{33}$ Either by virtue of some pre-legal wrongfulness or by virtue of the place they occupy in a wider system of regulation necessary to maintain certain goods. Thus 'mala in se', such as murder, rape, assault or physical endangerment, are wrongful by their very nature and are deemed to be wrongful independent of regulation. They are 'wrongful harms'. On the other hand 'mala prohibitata' such as driving on the wrong side of the road or various financial crimes, are wrong by operation of the law rather than some pre-legal wrongfulness. Nonetheless once a system is established to coordinate conduct and deviation from which undermines the system and gives rise to harm or the danger of harm, that in turn generates a wrong. In contrast to mala in se, mala prohibita are harmful wrongs. See Duff, Answering for Crime: Responsability and Liability in the Criminal Law (n 4) $153 \mathrm{ff}$.

${ }^{34}$ Duff, Punishment, Communication and Community (n 19) 59.

${ }^{35}$ Norrie (n 2) ch 2.

${ }^{36}$ Duff, Punishment, Communication and Community (n 19) ch 2.
} 
combining the strong, historically founded affective ties of 'the imagined community ${ }^{37}$ with the powerful institutions of the modern state and its monopoly over the use of force. In such a context, where individuals are presumed to identify as equal members of the wider community and share the basic values of that community, the criminal law as representing ties of civic responsibilities between citizens and a minimum shared normative understanding, the criminal law can be rationalised and justified. This purely national picture of criminal law has begun to change somewhat. One development that lies outside the scope of this thesis is the growth and increasing institutionalisation of international criminal law. Whether this represents a proto-cosmopolitan community encompassing all of humanity to which all persons are potentially accountable is open to question. ${ }^{38}$ The power to legislate on criminal matters also exists at a sub-state level and can be rationalised as shifts in the understanding of community within a federal context. Nonetheless, it remains the case that both citizenship and criminal law are typically considered within the context of a national community.

The European Union is not a national community but does possess both a meaningful citizenship status and a substantial body of criminal law. And yet both citizenship and criminal law are inherently community based concepts. This does not however exclude the possibility of applying Duff's theory to criminal law within the European Union. In fact, given the ambiguities surrounding the exact nature of the Union as a political community and the novel nature of its citizenship in a post-national setting, an analysis of Union citizenship in the light of criminal law may reveal important features concerning both the status of Union citizenship and the broader community to which it relates. However, before we embark on such a task the remainder of this chapter will provide a brief introduction to both criminal law and citizenship in the European Union.

\section{The Role of the EU in Criminal Law}

The European Union affects criminal law in three main ways. Firstly, European Union law, as a law that enjoys primacy over national law requiring any conflicting national law be set aside, has in certain circumstances prevented Member States from either criminalising certain conduct or applying certain sanctions. Even when Member States are permitted to

\footnotetext{
${ }^{37}$ Benedict Anderson, Imagined Communities (2nd edn, Verso 2006).

${ }^{38}$ Duff, Answering for Crime: Responsability and Liability in the Criminal Law (n 4) 55.
} 
use criminal law within the scope of Union law, national criminal law remains subject to Union law principles of fundamental rights and proportionality. Secondly, European Union law must be implemented by Member States and must be done so in an effective manner. In a pair of cases the Court of Justice has recognised a general competence on the part of the Union to oblige Member States to adopt criminal sanctions in order to more effectively implement Union law. Both of these situations - where EU law affects national law negatively, by proscribing the use of criminal law, and positively, by prescribing the use of criminal law, were developed in what was known as the European Community. The third, final area where the EU affects criminal law was initially located in the ex-Third Pillar of the TEU, known as Justice and Home Affairs and allowed for approximation of national criminal law, judicial and police cooperation and the establishment of a number of criminal law enforcement agencies.

Firstly, the EU can affect national criminal law in a negative sense, preventing its application. As with all reserved national competences, national criminal law must be exercised in conformity with Union law. In practice this means that national criminal law may be set aside in the event that it conflicts with Union law. ${ }^{39}$ Given the far reaching potential impact of free movement provisions in the internal market, it is this area that has perhaps been the clearest in setting aside national criminal law. Union law might operate as outright defence, setting aside the prohibition contained in national criminal law. ${ }^{40}$ Similarly, Union law and in particular the operation of the principle of proportionality can call into question the application of criminal sanctions where a fundamental freedom is at stake. ${ }^{41}$ Thus, even when national criminal law that frustrates a fundamental freedom is permitted under Union law, its exercise is conditioned by the general principles of Union law, including fundamental rights and proportionality. One of the most extensive areas in which national criminal law interacts with Union law is in the free movement of persons, where national criminal law can be used to justify the expulsion of Union citizens but only under certain conditions. The treatment of this residual power of the Member States is dealt with in further detail in chapter 4 .

\footnotetext{
${ }^{39}$ See Estella Baker, 'Taking European Criminal Law Seriously’ (1998) Crim LR 361.

${ }^{40} \mathrm{Such}$ as the case of Bordessa in which a Spanish law criminalising currency export was set aside. See Joined Cases C-358/93 and C-416/93 Bordessa and Ors EU:C:1995:54, [1995] ECR I-361. For an account see Baker (n 39).

${ }^{41}$ Case C-193/94 Criminal proceedings against Sofia Skanavi and Konstantin Chryssanthakopoulos [1996] ECR I-929 in which the application of criminal sanctions for failure to comply with a regulation requiring exchange of foreign driving licences was deemed to be disproportionate. See further Baker (n 39).
} 
Union law has also impacted on national criminal law in a more positive sense; obliging Member States to enact criminal legislation to ensure to effective implementation of Union law. ${ }^{42}$ Based on a duty of sincere cooperation and the general principle of effectiveness of Union law, the Union has long obliged Member States to ensure the effective implementation of Union law. ${ }^{43}$ In Greek Maize the Court of Justice established an obligation to impose sanctions for the breach of Union law under conditions that were effective and equivalent to similar national breaches. ${ }^{44}$ In a controversial set of judgments and following much inter-institutional wrangling, this was later developed into a fullyfledged doctrine permitting the Union to oblige Member States to adopt criminal sanctions for the effective implementation of Union law. ${ }^{45}$ Since the Treaty of Lisbon this competence has been formalised in Article 83(2) TFEU, allowing the Union to adopt measures requiring Member States to criminalise certain acts, if necessary for the effective enforcement of other Union policies. ${ }^{46}$

Both of the above instances where Union law affect criminal law, both negatively and positively, flow from the fact that in these instances Member States are acting within the field of Union law, either by breaching rights of free movement or in implementing Union law. Both were implicit in the old Community competence and both are ancillary to other Union law policies. The Union has also adopted a more autonomous criminal law policy, generally focused around the issue of cross-border crime and criminal law enforcement. ${ }^{47}$ Initially, established as an system of quasi-international law under the Treaty of Maastricht under a separate pillar of the European Union it was partially 'communitarised' under the Treaty of Amsterdam before being incorporated within the main body of EU law under the

\footnotetext{
${ }^{42}$ Note this was originally termed the 'Community's' competence in criminal law rather than the Union in distinction to the competence exercised under the ex-Third Pillar of the TEU. For the sake of clarity, the terms Union law and the Union shall be used unless specific considerations require otherwise.

${ }^{43}$ See Michael Dougan, 'From Velvet Glove to the Iron Fist: Criminal Sanctions for the Enforcement of Union Law' in Marise Cremona (ed), Compliance and the Enforcement of EU Law (OUP 2012).

${ }^{44}$ Case 68/88 Commission v Greece (Greek Maize) EU:C:1989:339, [1989] ECR 2965.

${ }^{45}$ Case C-176/03 Commission v Council (Environmental Crimes) EU:C:2005:542, [2005] ECR I-7879 and Case C-440/05 Commission v Council (Ship Source Pollution) EU:C:2007:625, [2007] ECR I-9097. For an account see Anthony Dawes and Orla Lynskey, 'The Ever-Longer Arm of EC Law: The Extension of Community Competence into the Field of Criminal Law' (2008) 45 CML Rev 131 and Steve Peers, 'The European Community's Criminal Law Competence: The Plot Thickens' (2008) 33 EL Rev 399.

${ }^{46}$ See Steve Peers, EU Justice and Home Affairs Law (3 edn, OUP 2011) 769-777.

${ }^{47}$ Although as is explored elsewhere this criminal law competence was frequently justified as necessary to compensate for potential negative effects of free movement and the abolition of border controls. See Jorg Monar, 'The Dynamics of Justice and Home Affairs: Laboratories, Driving Factors and Costs' (2001) 39 JCMS 747. See also Wenceslas de Lobkowicz, 'L'Europe et la sécurité intérieure: Une elaboration par étapes' La Documentation Francaise, décembre 2001, No 5144-45.
} 
Treaty of Lisbon. ${ }^{48}$ Following the Treaty of Lisbon the EU can now be said to exercise criminal law competence in three areas. ${ }^{49}$

Firstly, the Union can adopt approximation measures to effectively harmonise national criminal legislation in a number of key areas, mostly linked with cross-border crime. ${ }^{50}$ The harmonisation or approximation must be of a minimum nature and is limited in scope to a closed list but nonetheless reflects a real, independent normative presence in the field. Under the institutional regime operating following the Treaty of Amsterdam the Union adopted a number of such approximating instruments (then known as Framework Decisions) in fields such as terrorism, drug trafficking, human trafficking, computer crime and organised crime, amongst others. ${ }^{51}$ This substantive criminal law competence of the Union in cross-border crimes, known as 'Euro-crimes', now sits alongside the competence of the Union described above to adopt harmonising measures for the effective enforcement of other Union policies. $^{52}$

Secondly, the Union enjoys a competence to facilitate judicial cooperation and in particular the mutual recognition of various judgments and orders adopted by national authorities including courts, prosecutors and other judicial bodies. ${ }^{53}$ This 'mutual recognition' competence was implicit in the pre-Lisbon framework but has since been elevated to a specific legal basis ${ }^{54}$ and given priority by political institutions. ${ }^{55}$ Mutual recognition is now the main tool in the Union's criminal law policy and in the creation of what has been termed an area of justice and a whole range of mutual recognition instruments, most notably the European Arrest Warrant Framework Decision (EAW FD), ${ }^{56}$ have been adopted by the Union. ${ }^{57}$ Mutual recognition is to be based on what has been termed 'mutual trust' between

\footnotetext{
${ }^{48}$ For an institutional history of justice and home affairs in the EU see Peers, EU Justice and Home Affairs Law (n 46) ch 2.

49 Albeit subject to specific institutional constraints see Jorg Monar, 'The Area of Freedom, Security and Justice' in Jurgen Bast and Armin von Bogdandy (eds), Principles of European Constitutional Law (2 edn, Hart, Verlag CH Beck 2010) and Stephen Coutts, 'The Lisbon Treaty and the Area of Freedom, Security and Justice as an Area of Legal Integration' (2011) 7 Croatian Yearbook of European Law and Policy 69.

${ }^{50}$ Art 83(1) TFEU.

${ }^{51}$ For a comprehensive account see Peers, EU Justice and Home Affairs Law $783 \mathrm{ff}$.

${ }_{53}$ Now contained in Article 83(2) TFEU.

${ }^{53}$ Article 82(1) TFEU.

${ }^{54}$ Art 83(1) TFEU.

${ }^{55}$ See The Stockholm Programme: An Open and Secure Europe Serving and Protecting Citizens [2010] OJ C $115 / 01$.

${ }^{56}$ Framework Decision 2002/584/JHA on the European arrest warrant and the surrender procedures between Member States (EAW FD) [2002] OJ L 190/1.

${ }^{57}$ For a comprehensive list see Peers, EU Justice and Home Affairs Law (n 46) 693-736.
} 
national authorities. In an effort to provide some basis for such trust the Union has also been entrusted with a competence to adopt harmonising instruments in the area of procedural rights. Since the Treaty of Lisbon an incremental approach has been taken in this field with the adoption of a number of specific instruments ${ }^{58}$ following a roadmap on procedural rights. 59

Finally, a number of Union agencies and information systems exist to facilitate cross-border cooperation in criminal law enforcement. ${ }^{60}$ Europol is an agency established under Union law and provides an institutional basis for information sharing and analysis and a framework for joint investigations through joint investigation teams. Europol is assisted in its task by the Europol Information System. ${ }^{61}$ Eurojust consists of national prosecutors, judges and senior police officers tasked with criminal investigations and prosecutions. Its role is to facilitate information exchange and cooperation between national agencies in situations of cross-border crimes. The Treaty of Lisbon also provides for the establishment of a European Public Prosecutors Office (EPPO). ${ }^{62}$ Initially to be tasked with prosecuting crimes against the Union's financial interests, its scope may be extended by Member States. An initial proposal by the Commission has met with serious national resistance, in particular amongst national parliaments, who have issued a 'yellow card' under the Early Warning System, effectively forcing the Commission to go back to the drawing board in relation to its proposal. $^{63}$

Finally, a word should be said regarding the Schengen Agreement signed between a select number Member States in 1984 and now extended to cover most, but not all of the Union and some, non-Union states such as Norway and Iceland. ${ }^{64}$ Those states, Ireland and the United Kingdom, which remain outside the main body of the agreement, may nonetheless

\footnotetext{
${ }^{58}$ Directive 2013/38/EU on the right of access to a lawyer in criminal proceedings and in European arrest warrnat proceedings, and on the right to have a third party informed upon deprivation of liberty and to communicate with third persons and with consular authorities while deprived of liberty [2013] OJ L 294/1, Directive 2012/13/EU on the right to information in criminal proceedings [2013] OJ L 142/1 and Directive 2010/64/EU on the right to interpretation and translation in criminal proceedings [2010] OJ L 280/1.

${ }^{59}$ Resolution of the Council on a Roadmap for strengthening procedural rights of suspected or accused persons in criminal proceedings [2009] OJ C 295/1.

${ }^{60}$ See generally Peers, EU Justice and Home Affairs Law (n 46) chs 11-12. See also Valsamis Mitsilegas, EU Criminal Law (Hart 2009) ch 4.

${ }^{61}$ Mitsilegas (n 60) ch 5.

${ }^{62}$ Art 86 TFEU.

${ }^{63}$ Vanessa Franssen, 'National Parliaments issue yellow card against the European Public Prosecutor's Office' (European Law Blog, 4 November 2013) <http://europeanlawblog.eu/?p=2025> accessed 20 July 2015.

${ }^{64}$ Peers, EU Justice and Home Affairs Law (n 46) $74 \mathrm{ff}$.
} 
opt-in on a case-by-case basis to specific measures. ${ }^{65}$ The Schengen Agreement was an agreement to abolish border controls and primarily concerns borders, visas and immigration control. Nonetheless, there are implications for criminal law and a number of elements concerned criminal law enforcement and recognition of judgments in a borderless area. There also exists a Schengen Information System containing details of criminal offences of third country nationals seeking entry to the Union. Of particular concern to any study of Union citizenship and criminal law is Article 54 of the Convention Implementing the Schengen Agreement (CISA) preventing an individual from being prosecuted in more than one Member State for the same act. The Schengen Agreement was incorporated within the European Union in the Treaty of Amsterdam and involved a complex process of dividing it between its criminal law and immigration, borders and asylum components when allocating it to different pillars of the Treaties. ${ }^{66}$

\section{Citizenship in the Union - A Short History}

European citizenship appeared on the political agenda in the early 1970s. A legal form of citizenship was long considered implicit in the free movement of persons while a 'political' vision of citizenship, closely tied to the notion of identity formation and loyalty was explicit in a number of political statements and policies throughout the 1970s and 1980s. European Council meetings in Paris and Copenhagen in the early 1970s called for reports on a 'European Union' resulting in the Tindermanns Report of 1976 that in turn contained a chapter on a 'Citizens' Europe'. At the same time the European Parliament became directly elected, laying the foundations for a pan-European democratic citizenship. From the perspective of identity and symbolism various measures were adopted such as a uniform passport, an anthem and flag. The Adonnoino reports in 1984 continued this work, stressing in particular possible voting rights in other Member States and presenting free movement as contributing towards the construction of a European citizenship. ${ }^{67}$

Alongside the political, identity-based, discourse, legal commentators noted the potential for a rights-based European citizenship rooted in European law. The rights accorded to

\footnotetext{
${ }^{65}$ Protocol 21, TFEU.

${ }^{66}$ Peers, EU Justice and Home Affairs Law (n 46) 36 ff.

${ }^{67}$ Epsen DH Olsen, 'Transnational European Citizenship: Tracing Conceptions of Citizenship in the European Integration Process' (PhD thesis, European University Institute, Florence 2008) ch 5.
} 
economically active individuals under the rules of the internal market were identified by Plender as an incipient form of European citizenship as early as $1976 .{ }^{68}$ This conclusion was only strengthened by the subsequent expansive jurisprudence of the Court of Justice granting directly enforceable rights of free movement and non-discrimination to individuals, interpreting both the material and personal scope of such rights expansively. ${ }^{69}$ Furthermore, while lawyers are prone to pay close attention to the actions of Courts, it would be negligent to ignore the important role of the European legislature in developing free movement rights for individuals. ${ }^{70}$ Legislation adopted on the free movement of workers and the selfemployed contained not only expansive economic rights of employment but were also careful to include a social and human dimension with equal treatment in social benefits and strong rights of family reunification. Indeed, a stated goal of the legislation was to promote the social integration of Community nationals. Finally, three directives, adopted at the beginning of the 1990s, extended some of these rights, particularly rights of residence, to non-economically active individuals, albeit under conditions of self-sufficiency. ${ }^{71}$

The citizenship that politically remained a discourse and was legally only implicit was rendered explicit in the Treaty of Maastricht. In response to Spanish demands in particular, in 1992 the Treaty of Maastricht inserted a new Part Two on Citizenship of the Union into the revised Treaty establishing a European Community. ${ }^{72}$ Citizenship of the Union was to be conferred on nationals of the Member States who were to 'enjoy the rights conferred by this Treaty and ...be subject to the duties imposed thereby. ${ }^{73}$ Citizens were granted rights to free movement and residence 'subject to the limitations and conditions laid down in [the] Treaty and the measures adopted to give it effect'. Citizens also had the right to consular protection of another Member State in a third country where his or her own Member State was not represented. Article 8(c) granted a right to petition the ombudsperson. Finally, Citizens of the

\footnotetext{
${ }^{68}$ Richard Plender, 'An Incipient Form of European Citizenship' in Francis Jacobs (ed), European Law and the Individual (North-Holland Publishing Company 1976).

${ }^{69}$ See for example Case 53/81 DM Levin v Staatssecretaris van Justitie EU:C:1982:105, [1982] ECR 1035 and Case 139/85 R H Kempf v Staatssecretaris van Justitie EU:C:1986:223, [1986] ECR 1741 regarding a relatively wide definition of 'worker'.

${ }^{70}$ See Niamh Níc Shuibhne, 'The Third Age of EU Citizenship' in Phil Syrpis (ed), The Juriciary, the Legislature and the EU Internal Market (CUP 2012) describing the development of free movement of persons as 'court fuelled but legislature led' at 334.

${ }^{71}$ Directive 90/364/EEC on the right of residence [1990] OJ L 180/26, Directive 90/365/EEC on the right of residence for employees and self-employed persons who have ceased their occupational activity [1990] OJ L 180/28 and Directive 93/96/EEC on the right of residence for students [1993] OJ L 317/59.

${ }^{72} \mathrm{Pt} 2$ TEC, Treaty on European Union, together with the complete text of the Treaty Establishing the European Community [1992] OJ C 224/1.

${ }^{73}$ Art 8 TEC [1992].
} 
Union were granted active and passive voting rights in relation to local and European elections in other Member States.

The initial reaction to this potentially bold development was a mixture of disappointment and hope. Most of the legal rights, particularly those of free movement and residence, were either already in existence and/or subject to further measures and especially limitations contained in the treaty, implying a simple repackaging of existing rights spread across the internal market and residence directives under the guise of 'citizenship'. While voting rights for Union citizens in second Member States, allowing non-nationals to participate for the first time in the democratic life of the nation, was a significant step for some Member States and required constitutional amendment, ${ }^{74}$ its failure to cover the most meaningful elections, namely national elections, significantly reduced its impact both from a symbolic and practical point of view. The failure of the new Union to develop a clear bill of fundamental rights and to associate this to the new status of citizenship was also seen as a failure. ${ }^{75}$ Other commentators were more hopeful and pointed to the potential of European citizenship. ${ }^{76}$ In their view it could provide the language and legal basis on which a meaningful status could be developed either by judicial interpretation or legislative action. At a conceptual level the introduction of Citizenship of the Union was therefore potentially significant not only from the point of view of the European Union in equipping it with a core concept of political legitimacy but also for the very concept of citizenship, introducing as it did a new form of post-national citizenship. ${ }^{77}$

While in the short term it seemed the pessimists may have been correct, after a short few years the Court of Justice appeared to confirm the basic hope of the optimists. Initially the Court of Justice made few references to citizenship and continued to decide cases on the free movement of persons provisions contained in the internal market. However, in Sala the Court relied directly on then Article 6 TEC to establish a right of non-discrimination, independent of the internal market through a combined reading of citizenship of the Union

\footnotetext{
${ }^{74}$ Specifically France and Spain see Síofra O'Leary, The Evolving Concept of Community Citizenship: From the Free Movement of Persons to Union Citizenship (Kluwer 1996) ch 6.

${ }^{75}$ Ibid Conclusion.

${ }^{76}$ See Dora Kostakopoulou, 'Ideas, Norms and European Citizenship: Explaining Institutional Change' 68 MLR 233, $233 \mathrm{ff}$ and further citations.

77 'European citizenship is also a conceptual challenge; that is, it has the capacity to change our understanding of citizenship and membership with a view to opening up new forms of political community.' Dora Kostakopoulou, 'European Citizenship: Writing the Future' (2007) 13 ELJ 623, 642.
} 
and the general prohibition on grounds of nationality found in Article 6 TEC (now Article 18 TFEU). ${ }^{78}$ This combined reading of the citizenship provisions and non-discrimination on the grounds of nationality was later used to considerable effect in extending the duties of solidarity owed by Member States to Union citizens. ${ }^{79}$ In Grzelczyk the extent of this equal treatment and solidarity was emphatically underlined with the Court famously declaring that 'Union citizenship is destined to be the fundamental status of nationals of the Member States, enabling those who find themselves in the same situation to enjoy the same treatment in law irrespective of their nationality ${ }^{80}$ In Baumbast the Court went a step further and established a free standing right to residence, directly effective and against which restrictive Member State measures were to be reviewed according to the principle of proportionality. ${ }^{81}$ In Bidar the principle on non-discrimination was combined with a proportionality analysis to produce the concept of a progressively strengthened status based on a migrant's level of integration. The Court of Justice held that when limiting the right to equal treatment to social benefits, a Member State must take into account the degree of integration an individual enjoyed in the host society. The more integrated a Union citizen, the stronger his claim to equal treatment. Finally, after some hesitation, a free standing right to free movement and in particular to be free of illegitimate obstacles to that movement, was established. ${ }^{82}$

By the beginning of the century, the basic contours of Union Citizenship had already been established in what Níc Shuibhne has described as the second age of citizenship. ${ }^{83}$ Through a combination of the residence directives, as sometimes radically supplemented or altered by the by the jurisprudence of the Court of Justice ${ }^{84}$ interpreting the Treaty articles on citizenship, Union Citizens were entitled to extensive and relatively unrestricted free movement and residence rights on the one hand and rights to non-discrimination, most clearly in the field of social benefits, on the other hand. If a Union citizen engaged in an

\footnotetext{
${ }^{78}$ Case C-85/96 Maria Martinez Sala and Freistaat Bayern EU:C:1998:217, [1998] ECR I-2694.

${ }^{79}$ See ex Case C-224/98 Marie-Nathalie D'Hoop v Office national de l'emploi EU:C:2002:432, [2002] ECR I6191 and Case C-456/02 Michel Trojani v Centre public d'aide sociale de Bruxelles (CPAS) EU:C:2004:488, [2004] ECR I-7573. For a critical account see Kay Hailbronner, 'Union Citizenship and Access to Social Benefits' (2005) 42 CML Rev 1245.

${ }^{80}$ Case C-184/99 Rudy Grzelczyk v Centre public d'aide sociale d'Ottignies-Louvain-la-Neuve (Grzelczyk) EU:C:2001:458, [2001] ECR I-6193, para 31.

${ }^{81}$ Case C-413/99 Baumbast and R v Secretary of State for the Home Department EU:C:2002:493, [2002] ECR I-7091.

${ }^{82}$ Case C-224/02 Heikki Antero Pusa v Osuuspankkien Keskinäinen Vakuutusyhtiö EU:C:2004:273, [2004] ECR I-5763 and Case C-403/03 Egon Schempp v Finanzamt München V EU:C:2005:446, [2005] ECR I-6421.

${ }^{83}$ Níc Shuibhne (n 70).

${ }^{84}$ See Michael Dougan, 'The Constitutional Dimension to the case law on Union Citizenship' (2006) 31 EL Rev 613.
} 
economic activity, most particularly employment, then he or she fell within the scope of the free movement provisions of the internal market and enjoyed more rights, particularly in fields relevant to employment, and was subject to fewer restrictions. However, even in this area, the language of citizenship was being used to extend the rights of individuals. ${ }^{85}$

However, it would be a mistake to view the development of Union citizenship as exclusively the handiwork of the Court of Justice. ${ }^{86}$ The legislature has also played a role, at times in tension, but mostly complementary to the Court. The thicket of legislative measures on the free movement of persons, some recent, some with a more vintage quality, and caselaw of the Court of Justice on citizenship was synthesised, simplified, codified and complemented by the passing of Directive 2004/38/EC or the 'Citizenship Directive' ${ }^{87}$ The Citizenship Directive codified and reformed the law of the free movement of persons. It brought the disparate statuses of worker, self-employed, self-sufficient and student under the rubric of 'citizenship' and applied common administrative procedures and rights of family reunification. Nonetheless, while ostensibly under the same status of 'citizen' within the text important differences of substance remained. The exact range of rights enjoyed by and the limitations those rights could be subject to were differentiated according to the type of activity in which an individual was engaged. The concept of a progressively strengthened status, visible in Bidar, was also reflected in the structure of the Directive. Not only were rights differentiated according to the activity of the migrant worker but also according to his length of residence. The longer a migrant was resident, a period that reflected his level of integration, the greater his right to equal treatment, the less conditions could be applied to his right of residence and the greater his protection from expulsion.

Since the passage and implementation of the Citizenship Directive, in addition to continuing to specify the contours of transnational solidarity, ${ }^{88}$ the case law of the Court has on interpreting and elaborating certain provisions of the directive and in particular details

\footnotetext{
${ }^{85}$ Francis Jacobs, 'Citizenship of the European Union - A Legal Analysis' (2007) 13 ELJ 591, 593-595.

${ }^{86}$ Níc Shuibhne (n 70) claiming that the development has been 'Court fuelled but legislature led' (p. 334). For a more recent analysis of the interaction between the Court and the legislature in the area of citizenship see Michael Dougan, 'The Bubble that Burst: Exploring the Legitimacy of the Case Law on the Free Movement of Union Citizens' in Maurice Adams and others (eds), Judging Europe's Judges: The Legitimacy of the Case law of the European Court of Justice (Hart 2013).

${ }^{87}$ Directive 2004/38/EC on the right of citizens of the Union and their family members to move and reside freely within the territory of the Member States (Citizenship Directive) [2004] OJ L 158/77 (Citizenship Directive).

${ }_{88}$ For example Joined Cases C-22/08 and C-23/08 Athanasios Vatsouras, Josif Koupatantze $v$ Arbeitsgemeinschaft (ARGE) Nürnberg 900 EU:C:2009:344, ECR [2009] I-4585.
} 
around the acquisition and enjoyment of the right to permanent residence. ${ }^{89}$ It has also revisited the question of equal treatment and social rights and in some cases adapted its stance in light of the Directive. In particular, the Court appears to be increasingly willing to take its cue from the Directive in relation to the period of time that may indicate a sufficient degree of integration in the host society allowing the five year period indicated for the acquisition of permanent residence to be used as an indication of an individual's degree of integration. Thus in the case of Förster, the Court upheld a Dutch condition of five years residence before students could access social assistance as appropriate in light of Article 24(2) Directive 2004/38/EC. ${ }^{90}$ Similarly, in the case of Wolzenburg the Court allowed a five year period to be used to delimit the scope of equal treatment in sentencing matters, in particular the right to serve a sentence in the host member state. ${ }^{91}$ The law on Union citizenship has therefore been the story of a close dialogue between the Court of Justice and the Union legislature and a collaboration in the development of core principles and concepts. ${ }^{92}$

This collaboration has been called into question more recently by a recent line of case law developed by the Court of Justice on the basis not of the rights outlined in Article 21 TFEU and elaborated upon in legislation but rather the status of Union citizenship contained in Article 20 TFEU. In a short and cryptic decision of 2011 the Court of Justice ruled that Member States cannot take measures that would deprive citizens of the Union of the 'genuine enjoyment of the substance of the rights conferred by virtue of their status as citizens of the Union. ${ }^{93}$ Strikingly, this right was enforceable against the Member State of nationality or one's 'own' Member State, implying that the status of Union citizenship was somehow independent and the protection offered by that status could be exercised vis-à-vis

\footnotetext{
${ }^{89}$ Ex Case C-162/09 Secretary of State for Work and Pensions v Taous Lassal [2010] ECR I-9217 Case C162/09 Secretary of State for Work and Pensions v Taous Lassal EU:C:2010:592, [2010] ECR I-9217 and Joined Cases C-424/10 and C-425/10 Tomasz Ziolkowski \& Barbara Szeja \& Oths v Land Berlin (Ziolkowski) EU:C:2011:866, [2011] ECR I-14035.

${ }^{90}$ Case C-158/07 Jacqueline Förster v IB-Groep EU:C:2008:630, [2008] ECR I-8507 paras 52-53. Förster was decided after the adoption of Directive 2004/38/EC but before its transposition. Nonetheless the Dutch rules at issue were adopted in preparation for the implementation of the directive and the Court of Justice made explicit reference to the Directive in its judgment.

${ }^{91}$ Case C-123/08 Dominic Wolzenburg EU:C:2009:616, [2009] ECR I-9621.

${ }^{92}$ See Níc Shuibhne (n 70) and Dougan, 'The Bubble that Burst: Exploring the Legitimacy of the Case Law on the Free Movement of Union Citizens' (n 86).

${ }^{93}$ Case C-34/09 Gerardo Ruiz Zambrano v Office national de l'emploi (ONEm) EU:C:2011:124, [2011] ECR I1177 para 42.
} 
national authorities even of the state of nationality. However, the short seven paragraphs ${ }^{94}$ perhaps reflected a lack of consensus on the part of the Court and of a clear concept of what such a status might entail. It is therefore of no surprise that the follow up to this ground breaking decision was distinctly hesitant, seemingly limiting its application to the very exceptional situations where a Union citizenship was either deprived entirely of his status as citizen ${ }^{95}$ or where he would be forced to leave the territory of the Union entirely. ${ }^{96}$ While the potential for the further development of Union citizenship as an independent status carrying with it independent rights certainly remains, to date its practical impact has been extremely limited. ${ }^{97}$

While most of the developments of Union citizenship have taken place on a legal level, focused on the rights of free movement, residence and non-discrimination of individuals, particularly (although not exclusively) in cross-border situations, there have also been moves, particularly in the Treaty of Lisbon to inject a democratic element into the status of Union citizenship. As mentioned above, the European Parliament has been directly elected since $1979,{ }^{98}$ although the exact link between European Parliament voting rights and Union citizenship remains ambiguous. ${ }^{99}$ The right to vote and to stand as a candidate in a second Member State in European Parliament and local elections were explicitly rights of Union citizenship and introduced in the Treaty of Maastricht. These were later elaborated upon in a set of Directives providing for the conditions under which migrant citizens could vote in European $^{100}$ and local elections ${ }^{101}$ and harmonising to some extent the modalities of

\footnotetext{
${ }^{94}$ For a sharp critique of the Court's reasoning, or lack therefore, see Niamh Níc Shuibhne, 'Seven Questions for Seven Paragraphs' (2011) 36 EL Rev 161.

${ }^{95}$ Case C-135/08 Janko Rottmann v Freistaat Bayern EU:C:2010:104, [2010] ECR I-1449.

${ }^{96}$ Case C-434/09 Shirley McCarthy v Secretary of State for the Home Department EU:C:2011:277, [2011] ECR I-3375, Case C-256/11 Murat Dereci and Others v Bundesministerium für Inneres (Dereci) EU:C:2011:734, [2011] ECR I-11315, Case C-87/12 Ymeraga v Minstre du Travail, de l'Emploi et de l'Immigration EU:C:2013:291.

${ }^{97}$ For one vision of what the implications of such a status might be see Armin Von Bogdandy and others, 'Reverse Solange - Protecting the Essence of Fundamental Rights against EU Member States' (2012) 49 CML Rev 489.

98 Act concerning the election of the representatives of the Assembly by direct universal suffrage [1976] OJ L $278 / 5$.

${ }^{99}$ See Case C-145/04 Spain v UK EU:C:2006:543, [2004] ECR I-7902 and Joined Cases C-300/04 Eman and Sevinger v College van Burgemeester en Wethouders van Den Haag EU:C:2006:545, [2006] ECR I-8055.

${ }^{100}$ Directive 93/109/EC laying down detailed arrangements for the exercise of the right to vote and stand as a candidate in elections to the European Parliament for citizens of the Union residing in a Member State of which they are not nationals (Uniform Election Procedure) [1993] OJ L 329/34.

${ }^{101}$ Directive 94/80/EC laying down detailed arrangements for the exercise of the right to vote and to stand as a candidate in municipal elections by citizens of the Union residing in a Member State of which they are not naionals [1994] OJ L 368/38 as amended by Council Directive 96/30/EC [1996] OJ L 122/14.
} 
European parliamentary elections. ${ }^{102}$ Finally, in the Treaty of Lisbon there has been a concerted effort to broaden the range of political participation and introduce forms of participatory democracy, through representative institutions and civil society, ${ }^{103}$ and direct democracy through the innovative 'citizenship initiative', requiring the Commission to respond to a request by a minimum of one million citizens from a number of member states to legislate on a particular matter. ${ }^{104}$ This innovative measure has been introduced along with more traditional means of increasing democratic input such as increasing the powers and role of the European Parliament and through involving national parliaments more closely in European governance matters. ${ }^{105}$

At this stage the basic shape and role of Union citizenship in the EU can be discerned. Union citizenship is a status that is dependent on national citizenship - it is derivative in nature. Moreover it is exercised primarily (although not exclusively) vis-à-vis other Member States in the Union, it is primarily concerned with the situation of cross-border movement. Arising out of the internal market, it provides the holder with a series of rights, primarily of free movement and non-discrimination when travelling to other Member States. Political rights include the right to participate in local and European elections in a second Member State. Union citizenship is less important as a status vis-à-vis the Union itself, either directly at a Union level, or as a supranational guarantee or protection against national abuses. If citizenship is a relational concept, linking an individual to a political community, then Union citizenship is a multi-layered status, establishing links with various political units within the broader structure of the Union and is strongest in establishing horizontal relations with other Member States, and distinctly less developed in establishing vertical relations with the Union. This basic structure of a multi-levelled, inter-state citizenship is elaborated in more detail in chapter two and is used as a framework for an analysis of the effect of criminal law on Union citizenship in the rest of this thesis.

\footnotetext{
${ }^{102}$ Uniform Election Procedure (n 100).

103 See Joana Mendes, 'Participation and the Role of Law After Lisbon: A Legal View on Article 11 TEU' (2011) 48 CML Rev 1849.

${ }^{104}$ Art 11 TEU. Regulation 211/2011/EU on the citizens' initiative [2011] OJ L65/1 has also been adopted at 'breakneck speed'. For an analysis see Michael Dougan, 'What are we to Make of the Citizens' Initiative' (2011) 48 CML Rev 1807 and Luis Bouza Garcia, 'The European Citizen's Initiative: A New Institution for Empowering Europe's Citizens?' in Michael Dougan, Niamh Níc Shuibhne and Eleanor Spaventa (eds), Empowerment and Disempowerment of the European Citizen (Hart 2012).

105 See Gavin Barrett, 'Introduction - A New Improved Formula? The Treaty of Lisbon and National Parliaments ' in Gavin Barrett (ed), National Parliaments and the European Union: the Consitutional Challenge for the Oireachtas and other member state legislatures (Clarus Press 2008).
} 


\section{Conclusion: \\ Method and Framework of Analysis}

The goal of this thesis is to determine what the operation of criminal law in the Union can reveal about Union citizenship and the political community of the Union more generally. It is therefore primarily a thesis about Union citizenship and how it is affected by Union law, rather than attempting to provide a comprehensive explanatory or justificatory account of EU criminal law. Certainly, certain aspects of citizenship and of how it interacts with criminal law can contribute to a better explanation of the cause and in particular the structure of EU criminal law and may provide a framework for legitimacy for some of the more controversial aspects of EU criminal law, such as mutual recognition. To the extent that this thesis touches on these issues they are noted. However, that is not the perspective or ambition of this thesis. This thesis is concerned with the potential impact of criminal law and the treatment of criminal law by the Court and the Union legislature on Union citizenship and the political community of the Union.

To that end this thesis adopts the criminal law theory of RA Duff based on the links between citizenship, crime and community. This is an explanatory and a justificatory theory for criminal law through an examination of the structure of responsibility that lies behind the criminal law. Other analytical and normative theories of criminal law attempt to synthesis and explain the criminal law or alternatively lay down criteria for justifying punishment or identifying what acts are properly the subject of criminalisation. ${ }^{106}$ While at times drawing on other criminal law theorists, this thesis relies principally on Duff's theory, primarily for its methodological suitability; it is centred on the concept of citizenship and provides a framework for understanding the many dimensions of the criminal justice system - the crime, the trial, punishment and the victim - in terms of citizenship and community.

Duff's theory uses the concept of citizenship and community to explain and justify criminal law. This thesis adopts the reverse approach, using the concept of criminal law, seen in a communitarian light and based on the notion of membership and citizenship, to explain certain aspects of citizenship and the political community in a particular polity; the European Union. The criminal law is thus presented as a set of wrongs, based in the particular values

\footnotetext{
${ }^{106}$ For an overview see Duff, Theories of Criminal Law (n 15).
} 
of a community and criminal responsibility is seen as being founded on the concept of membership or citizenship. The criminal law has an expressive quality and punishment has a communicative purpose. Finally, being prosecuted, tried and punished involves a process of being called to account for ones actions before the community in a public dialogue involving accusation, justification, excuse and condemnation.

This thesis looks specifically at the possible links between the status of Union citizenship and criminal law. In order to provide a framework for this analysis Chapter Two breaks Union citizenship into separate components, namely a transnational dimension and a supranational dimension. The transnational dimension is subsequently divided into two subdimensions, social integration and autonomy, that can be discerned as two, at times opposing and at times complementary, principles that drive much of the legal practice in Union citizenship. The supranational dimension of Union citizenship, while present, is less welldeveloped than transnational citizenship. However, while presented as distinct, the two transnational dimensions and the supranational dimension can be said to be connected and to mutually influence each other. Through a combination of the right to social integration in other Member States and a right to move freely throughout the Union, Union citizenship gives rise to a single area of movement to which a certain supranational reference for Union citizenship can be said to emerge. Thus Union citizenship and the political community it represents is a complex interaction of national, transnational and supranational that combined form a multi-levelled, composite political community.

Chapters three and four together consider the impact of criminal law in the context of the social integration dimension of Union citizenship. A brief section introduces these two chapters and relates the concept of social integration in criminal law to Union citizenship. In criminal law social integration arises in two instances. Firstly, social integration is seen as a goal of punishment namely the social rehabilitation of the offender. This use of social integration is analysed in chapter three. Secondly, criminal activity is said to constitute a rejection of the norms of society and a failure to integrate into society; this aspect of social integration is analysed in chapter four. The Court has used both of these criminological understandings of social integration and has integrated them within the social integration dimension of Union citizenship, altering it and leading to both the greater inclusion and greater exclusion of Union citizens in host Member States. 
Chapter five and chapter six consider the construction of an Area of Justice through two instruments in particular, the European Arrest Warrant Framework Decision (EAW FD) and Article 54 of the Convention Implementing the Schengen Agreement (CISA). A brief section introduces these two chapters and considers the links between an area of movement associated with the autonomy dimension of citizenship and the Area of Justice. Chapter five characterises the European Arrest Warrant as a system of shared enforcement of national criminal law. Chapter six details how the Court of Justice has constructed a single status for individuals in a single area through a free movement driven interpretation of the ne bis in idem principle contained in Article 54 CISA.

Chapter seven considers the possibility of a community at a supranational level arising from the adoption of substantive criminal law by the Union itself. It is seen that the Union's ability to directly bind individuals and identify supranational wrongs is limited, mirroring the weaker supranational dimension of Union citizenship. Nonetheless, in certain areas it does appear to be capable of expressing supranational values or identifying supranational public goods capable of engaging the Union's interest as a whole. However, the most important role of supranational criminal law is perhaps not to provide an autonomous expression of supranational values at a Union level but rather to frame national criminal law and facilitate transnational legal processes involving criminal law. There is therefore an interaction between the supranational and national through transnational processes. A normative community does emerge at a supranational level but arising from various interacting national communities.

A conclusion draws the different elements of the thesis together and discusses the consequences for our understanding of Union citizenship and the political community of the Union. The ways in which a communitarian analysis of the criminal law can complement our understanding of citizenship are outlined. Finally, the main conclusion of this thesis is that it is through transnational processes that a supranational community can be said to emerge. 


\title{
Chapter 2
}

\section{Union Citizenship:}

\section{Between Transnational and Supranational}

\begin{abstract}
Introduction
To recall, according to Duff criminal law governs the relations between the individual and the community or more accurately the relations between individuals in their capacity as members of the community. It regulates behaviour according to the core values and norms of the community, which in contemporary liberal democracies include first and foremost, but not exclusively, individual freedom. Following the premise that core individual interests must be protected from undue interference in the interests of maximising liberty for all, the harm principle provides a basic but not a comprehensive principle for the criminal law. It forms the basis of many, if not most, wrongs but is supplemented by other wrongs done either to the community as a whole or other individuals as members of that community. The result is a moral and contextualised account of the criminal law based on the particular community in which it is applied and where the exact content of the criminal law varies from time to time and from place to place. The responsibilities contained in the criminal law flow from the relationship between individuals in the civic community ie as co-citizens. We are called to account as citizens by the political community for wrongs done to other citizens. From this brief sketch of Duff's theory emerges the broad outline of a criminal justice system that is based on the idea of public wrongs, defined according to the prevailing norms and values of a particular community and justified by ties of responsibility between individuals in their capacity as members of that community. ${ }^{1}$
\end{abstract}

The question arises of what this model of a citizen-centred account (both normative and descriptive) of criminal law can reveal concerning the links between Union citizenship and criminal law. Before we can answer that question we must look at the specificities of the

\footnotetext{
${ }^{1}$ See RA Duff, Punishment, Communication and Community (OUP 2003), RA Duff, Answering for Crime: Responsability and Liability in the Criminal Law (Hart 2007) and the account provided in the Introduction.
} 
European Union as a political community and the particular form and structures of its membership status, namely Union citizenship.

This chapter explores the rights of Union citizenship with an eye to describing the nature of the links established by that status between individuals and Member States and between individuals and the Union as a whole. The relationship between Union citizens and Member States is analysed first. This relationship is governed by two principles, autonomy and integration, that combined create a transnational status allowing individuals to enjoy the opportunities offered by a broader geographical space spread over a number of national communities. The relationship between individuals and the Union itself is less developed. Following a series of cases in recent years the existence of this 'supranational' dimension to Union citizenship is now beyond doubt. However, while the status is clearly established, its content in terms of rights and duties remains ill-defined and insubstantial. The resulting picture is of a nested membership status establishing links primarily with a set of national communities on the basis of social integration and autonomy and the presence of a discernable but weaker overarching community at a supranational level.

The argument of this chapter is not that the shaping of Union citizenship into these separate elements has been by conscious design or that it reflects distinct lines of caselaw or legal practice adopted explicitly by either the Court of Justice or the Union legislature. The history of Union citizenship is a status that grew out of the internal market in a relatively organic fashion, ${ }^{2}$ instituted as a political stratagem in the Treaty of Maastricht ${ }^{3}$ and gradually shedding its economic legacy through incremental steps taken by the Court of Justice, ${ }^{4}$ complemented by legislative activity. ${ }^{5}$ Union citizenship, like citizenship generally, can be

\footnotetext{
${ }^{2}$ At least in its legal sense. For an analysis of Union citizenship as a political practice inter alia see Epsen DH Olsen, 'Transnational European Citizenship: Tracing Conceptions of Citizenship in the European Integration Process' (PhD thesis, European University Institute, Florence 2008).

${ }^{3}$ Síofra O'Leary, The Evolving Concept of Community Citizenship: From the Free Movement of Persons to Union Citizenship (Kluwer 1996) ch 1. See also Luuk van Middelaar, Passage to Europe: How a Continent became a Union (Liz Waters tr, Yale University Press 2013) 258-259.

${ }^{4}$ See in particular the paradigm shifting cases of Case C-85/96 Maria Martinez Sala and Freistaat Bayern EU:C:1998:217, [1998] ECR I-2694, Case C-184/99 Rudy Grzelczyk v Centre public d'aide sociale d'OttigniesLouvain-la-Neuve (Grzelczyk) EU:C:2001:458, [2001] ECR I-6193, Case C-413/99 Baumbast and R $v$ Secretary of State for the Home Department EU:C:2002:493, [2002] ECR I-7091 and Case C-209/03 The Queen (on the application of Dany Bidar) v London Borough v Ealing, Sec. of State for Education and Skills EU:C:2005:169, [2005] ECR I-2119 amongst others.

5 Initially the 'residence directives': Directive 90/364/EEC on the right of residence [1990] OJ L 180/26; Directive 90/365/EEC on the right of residence for employees and self-employed persons who have ceased their occupational activity [1990] OJ L 180/28 and Directive 93/96/EEC on the right of residence for students [1993] OJ L 317/59. These later being replaced and consolidated with other legislation on the free movement of
} 
viewed from a variety of perspectives ${ }^{6}$ and a number of political and legal forces, not always acting in harmony, have contributed to its fashioning. ${ }^{7}$ The purpose of this chapter is to deconstruct and reconstruct the caselaw and legislative practice of citizenship in order to provide some rationality to the multiple strands of legal practice ${ }^{8}$ and to provide a framework for the rest of this thesis. The vision of Union citizenship presented here serves a methodological purpose; to break Union citizenship into component parts to provide a framework for an analysis of its interaction with criminal law. The choice of specific components serves an additional methodological purpose related to both Union citizenship and Duff's theory. Duff's theory is specifically community based, describing and justifying the criminal law as an expression of a particular community. Another goal of this thesis is to demonstrate how the treatment of criminal law in the Union, can contribute to our understanding of the structure of the Union as a political community. Thus the dimensions of social integration, autonomy and supranational are selected with an eye to the different links that Union citizenship forges with different component parts - national and supranational of the Union's political community and hence to indirectly characterise that political community.

\section{The Transnational Dimension of Union Citizenship}

Union citizenship arose from the internal market and in particular the free movement of the economically active, principally workers and the self-employed, and the economically selfsufficient. The market origins of Union citizenship attracted the particular criticism of Everson, who denounced the instrumentalist and instrumentalised individual that arose from

persons into Directive 2004/38/EC on the right of citizens of the Union and their family members to move and reside freely within the territory of the Member States (Citizenship Directive) [2004] OJ L 158/77 (Citizenship Directive). See Niamh Níc Shuibhne, 'The Third Age of EU Citizenship' in Phil Syrpis (ed), The Juriciary, the Legislature and the EU Internal Market (CUP 2012) for a history of Union citizenship taking into account the interaction between the legislature and the judiciary.

6 A particular distinction might be made between a political perspective and a legal perspective. For an alternative early account of different elements of Union citizenship see Jo Shaw, 'Citizenship of the Union Towards Post-National Membership' Jean Monnet Working Papers 06/97 <http://centers.law.nyu.edu/jeanmonnet/archive/papers/97/97-06-.html> accessed 22 July 2015.

${ }^{7}$ For a superb account of the early years of Union citizenship up to and in the years after its introduction as a formal status in the Treaty of Maastricht see Paul Magnette, La Citoyennéte Européenne (Editions de l'Université de Bruxelles 1999).

${ }^{8}$ In this sense it is an exercise in rational reconstruction per MacCormick see Neil MacCormick, 'Reconstruction after Deconstruction: A Response to CLS' (1990) 10 OJLS 539. 
such a historical context. ${ }^{9}$ It is arguable whether Union citizenship has evolved beyond its market origins. Commentators have pointed out that in one of the first meaningful citizenship cases, Sala, the Court of Justice divorced free movement from the condition of economic activity, to eventually give rise to a 'fifth fundamental freedom' ${ }^{10}$ However, more recently O'Brien has pointed out the differentiated nature of Union citizenship and the various 'rights cliffs' that arise from the continued importance of economic activity in claiming rights under Union law. ${ }^{11}$ Regardless of the role economic activity per se plays in activating and sustaining Union citizenship rights, what is undeniable is the structural legacy that the internal market has bestowed on Union citizenship. Níc Shuibhne is particularly clear in pointing out the enduring transnational and cross-border nature of Union citizenship. ${ }^{12}$ While this is presented as the continuing importance of 'market citizenship', many of the case-studies provided by Níc Shuibhne point not to the economic importance of Union citizenship as an individual status in a constitutionalised market, but rather the transnational character of Union citizenship, ${ }^{13}$ a character that clearly originates in the nature of the internal market. ${ }^{14}$

The core rights of Union citizenship remain free movement and non-discrimination. These two principles combine in different ways to form two distinct features of Union citizenship as a transnational status: autonomy and integration. An emphasis on free movement tends to privilege autonomy and non-discrimination social integration, however this is not to say that non-discrimination is irrelevant to autonomy or that free movement is irrelevant to integration. Both principles interact and reinforce each other; it is the manner of their

\footnotetext{
9 Michelle Everson, 'The Legacy of the Market Citizen' in Jo Shaw and Gillian More (eds), New Legal Dynamics of European Union (Claredon Press 1995).

${ }^{10}$ Ferdinand Wollenschläger, 'A New Fundamental Freedom beyond Market Integration: Union Citizenship and its Dynamics for Shifting the Economic Paradigm of European Integration’ (2011) 17 ELJ 1.

${ }^{11}$ Charlotte O'Brien, 'I Trade, therefore I Am: Legal Personhood in the European Union' (2013) 50 CML Rev 1643.

${ }^{12}$ Niamh Níc Shuibhne, 'The Resilience of EU Market Citizenship' (2010) 47 CML Rev 1597.

${ }^{13}$ The account of Union citizenship as a transnational status overlaps somewhat with that offered by Iliopoulou Penot, see Anastasia Iliopoulou Penot, 'The Transnational Character of Union Citizenship' in Michael Dougan, Niamh Níc Shuibhne and Eleanor Spaventa (eds), The Empowerment and Disempowerment of the European Citizen (Hart 2012).

${ }^{14}$ Indeed Níc Shuibhne sees this as an advantage, given the constitutionalized nature and status of the market in Union law: 'While it seems counter-intuitive, a theory of market citizenship actually takes seriously the call to put the person at the centre of the EU project...[I]t is not that market citizenship must inherently fall short, but rather that we tend artificially to constrain the capacity of the market and to overlook the normative as well as economic capacity of a constitutional market.' Níc Shuibhne, 'The Resilience of EU Market Citizenship' (n 12) 1609.
} 
combination that reveals an emphasis on autonomy or social integration. The two concepts of autonomy and integration infuse the case law on Union citizenship.

In many ways they are largely complementary; the autonomy that Union citizenship grants individuals to enjoy a wider space of movement and opportunity facilitates precisely the integration in other Member States. However, on a more abstract level and if pushed to extremes they reveal two visions of Union citizenship and of the Union citizen that can be in tension, if not downright opposition that can crudely be categorised as a communitarian/liberal divide. On the one hand an emphasis on autonomy may be said to lead to a particularly individualistic notion of Union citizenship, independent of communal ties of affection, cultural and solidarity. ${ }^{15}$ On the other hand an emphasis on integration might justify the imposition of a duty of assimilation into the host society and an acceptance of its social, economic and political values. At the very least it implies the adoption of a new social identity and the preservation of national ties of identity albeit with the important proviso that they are open to other Union citizens.

\section{Transnational Citizenship as Autonomy}

As the name suggests, free movement can easily be understood as liberating for individuals. In its legal operation it is largely concerned with the removal of barriers that individuals face, not simply in moving but in participating in a whole host of activities with a crossborder impact. Indeed, the condition of cross-border effect is so easily met that in the internal market the rights of free movement can be convincingly presented as a freedom from unwarranted interference with the exercise of an economic activity. ${ }^{16}$ Thus free movement can be seen as providing a supranational guarantee of freedom or choice for individuals. While initially limited to non-discrimination on the grounds of nationality, Union citizenship, as with other freedoms, gradually included a right to be free from unjustified barriers to free movement. ${ }^{17}$ In the context of Union citizenship the principle

\footnotetext{
${ }^{15}$ For a critique of such a vision of Union citizenship and in particular its tendencies to exacerbate economic inequalities see Michelle Everson, 'A Very Cosmopolitan Citizenship: But who Pays the Price?' in Michael Dougan, Niamh Níc Shuibhne and Eleanor Spaventa (eds), Empowerment and Disempowerment of the European Citizen (Hart 2012).

${ }^{16}$ Eleanor Spaventa, Free Movement of persons in the European Union: Barriers to Movement in their Constitutional Context (Kluwer Law International 2007).

${ }^{17}$ The breakthough occurring in the cases of Case C-224/02 Heikki Antero Pusa v Osuuspankkien Keskinäinen Vakuutusyhtiö EU:C:2004:273, [2004] ECR I-5763, Case C-192/05 K. Tas-Hagen and R. A. Tas v Raadskamer WUBO van de Pensioen- en Uitkeringsraad EU:C:2006:676, [2006] ECR I-10451 and Case C-403/03 Egon Schempp v Finanzamt München V EU:C:2005:446, [2005] ECR I-6421.
} 
takes on a more expansive role, being linked to the various and virtually unlimited facets of an individual's personal and social life. To simplify somewhat, free movement in the context of Union citizenship has been deployed to protect an individual's right to pursue a life in various Member States. Member States must facilitate and recognise the right to move between various national communities within the Union. Legally this implies a right to carry rights and civil status acquired in one Member State throughout the Union. While initial cases tended to somewhat awkwardly fit this right into a discriminatory analysis ('discrimination against movers') later cases properly recognised the free movement basis for this right. This tendency can be seen in two areas in particular, names and family life. In both areas not only must host Member States facilitate migrants but also home Member States. This has been mirrored by legislation, particularly in the field of private international law, which emphasis the free movement of individuals and the portability of a civil status. ${ }^{18}$ When migrants move, Member States must recognise and facilitate the rights acquired under the law of other Member States. It is not therefore a right of integration, to move to and settle permanently in another Member State, but rather a right of migration back and forth, to build one's life on the basis of that migration and to enjoy the broader range of possibilities that Union citizenship offers. The result is a wider space of free movement, choice and autonomy.

\section{Names and Civil Status}

In Garcia Avello Belgium was required to recognise the double barrel name of a dual national Belgian-Spaniard, despite the fact that Belgian naming rules required children to be named after their father alone. ${ }^{19} \mathrm{Mr}$ Garcia-Avello was not asking that his children be treated the same as other Belgians, on the contrary he was asking to be treated differently. The Court granted this wish by employing a somewhat tortuous discrimination analysis that in the end was nonetheless based on a movement rationale. According to the Court of Justice, the Garcia-Avello children, as dual nationals of Spanish and Belgian nationality, were not in the same position as 'single national' Belgian children. In later life they may move to Spain and would there encounter various professional, educational and personal difficulties due to the discrepancy between their Belgian registered name and their Spanish registered name. The

\footnotetext{
${ }^{18}$ See for example Regulation 2201/2003/EC concerning jurisdiction and the recognition and enforcement of judgments in matrimonial matters and the matters of parental responsibility [2003] OJ L 338/23.

${ }^{19}$ Case C-148/02 Carlos Garcia Avello v Belgian State EU:C:2003:539, [2003] ECR I-11613.
} 
principle of non-discrimination required that like situations be treated similarly and that unlike situations be treated differently. As the Garcia-Avello family were unlike other Belgian children it would be discriminatory to treat them in the same way when it came to naming rules. The Belgian practice therefore constituted a breach of then Article 12 TEC (now Article 18 TFEU). However, while on the face of it the case was an exercise in the application of the principle of non-discrimination, it was because of potential future movement, and the barriers to that movement that might arise as a consequence of their names, that they constituted a different class and accordingly faced discrimination. Through a creative construction of the comparator the Court was able to shoe-horn what was essentially a free movement analysis into a non-discriminatory framework. The ethos behind the case was that the Garcia-Avello family, and children in particular, should not be disadvantaged by the possibility of them building transnational life with links to both countries and to some extent autonomous of at least one of their home states.

The free movement rationale and the implications for transnational autonomy were rendered explicit in the case of Grunkin Paul. ${ }^{20}$ Leonard Matthias was born of German parents in Denmark who gave him a double-barrelled surname, as was permitted under Danish law. Upon return to Germany however the relevant authorities refused to register the name Grunkin-Paul, the use of double barrelled names being generally prohibited in Germany. In contrast to Garcia Avello, the Court found that there was no discrimination on the grounds of nationality; both parents and the child were German and sought to register the child's name in Germany and objected to the application of German rules. Instead of an analysis based on discrimination the Court focused on free movement. A difference in an individual's name on various official documents could represent a serious inconvenience for Leonard Matthias in later life. In particular the Court was concerned to facilitate his life in both his state of residence and his state of nationality, recognising the cross-border and transnational nature of his life. ${ }^{21}$ Member States in short would have to adapt their regulations, even those that were not discriminatory, to take into account the transnational life choices made by Union citizens. Union citizenship facilitates not simply movement to another Member State and integration into a new host society, but a right to participate to varying extents in different national communities and to be free from restrictions in pursuing such a transnational life. The key point to take from Grunkin Paul is the obligation on the part of the 'home' Member

\footnotetext{
${ }^{20}$ Case C-353/06 Stefan Grunkin and Dorothee Regina Paul EU:C:2008:559, [2008] ECR I-7639.

${ }^{21}$ Ibid para 26.
} 
State to recognise the rights and personal situation acquired by the Union citizen under the law of another Member State.

However, this right of autonomy of individual is not absolute. It can, in specific circumstances, be opposed by the particular interests, needs and indeed constitutional values of a particular Member State. In Sayn-Wittgenstein the Austrian applicant sought to retain a title of Princess (Fürstin) acquired in Germany following her adoption by a German Prince and that she had held and operated a business under selling castles and other stately homes for a period of 15 years. ${ }^{22}$ The Court noted that her situation was comparable with GrunkinPaul. In fact given her professional life and the use to which she put her title, the inconveniences presented by a change in name would be even more direct and apparent in her case. ${ }^{23}$ Where Sayn-Wittgenstein differed from Grunkin-Paul was in the justification presented by the Member State. The abolition of titles of nobility represented a key feature of the establishment of the Austrian Republic. It had constitutional status and was linked to the political identity of the state, an identity that could be understood in terms of public policy $^{24}$ and that was respected in EU law by virtue of Article 4(2) TEU. ${ }^{25}$ The law abolishing titles and therefore the measure disallowing Ms Sayn-Wittgenstien from using Fürstin in her official documents, was a justified restriction on her right of free movement and proportionate to the goal of preserving the constitutional identity of the Federal Republic of Austria.

Finally, in the case of Vardyn, while leaving the ultimate determination to the national court, the Court of Justice accepted the possibility that a discrepancy between the spelling of a husband's surname and the part of his wife's double barrelled surname arising from the application of national spelling rules could cause serious inconveniences and constitute a restriction on their rights under Article 21 TFEU. $^{26}$ It also accepted that such a restriction could be justified in light of the need to protect the official national language in order to 'safeguard national unity and preserve social cohesion.' Moreover the national language in question, Lithuanian, was claimed to constitute 'a constitutional asset which preserves the

\footnotetext{
${ }^{22}$ Case C-208/09 Ilonka Sayn-Wittgenstein v Landeshauptmann von Wein EU:C:2010:806, [2010] ECR I13693.

${ }^{23}$ Ibid para 63.

${ }^{24}$ Ibid para 84.

${ }^{25}$ Ibid para 92.

${ }^{26}$ Case C-391/09 Malgožata Runevič-Vardyn and Łukasz Pawet Wardyn v Vilniaus miesto savivaldybès administracija and Others EU:C:2011:291, [2011] ECR I-3787 paras 75-78.
} 
nation's identity, contributes to the integration of citizens and ensures the expression of national sovereignty, the indivisibility of the State and the proper functioning of the services of the State. ${ }^{27}$ Ultimately it left the question of whether the restriction was in fact proportionate to be determined by the national court. ${ }^{28}$

The overall message arising from the name cases is that Union citizenship facilitates choice and autonomy of individuals to pursue a transnational life, an autonomy that Member States must recognise and facilitate up to certain limits. Those limits relate not to administrative convenience or the needs of social assimilation but a desire to protect the linguistic and constitutional identity of the state. ${ }^{29}$ They demonstrate that the particular situations of crossborder individuals and families must be accommodated, both in a host member state, as in the case in Garcia Avello and upon movement to another Member State, including the state of nationality as in Grunkin Paul. While the judgements are phrased in terms of the transportability of civil status acquired in a particular Member State and the elimination of obstacles, the question of cultural identity also lies in the background, of both the individuals and of host community. If Garcia-Avello simply concerned the issue of national discrepancies in an individual's official name, an alternative would simply have been to oblige Spain to adapt its laws. Indeed, this would have arguably been a more appropriate solution given the reality of the children's actual lives in Belgium rather than the hypothetical of their future life in Spain. Instead the solution chosen by the Court privileges the parent's right to make a choice regarding the cultural identity of their children, emphasising their transnational roots in opposition to the local culture. Interestingly, a justification raised by both the Belgian and Danish governments in Garcia Avello was that an obligation to conform to the national regulations would in fact facilitate integration - a clear indication of a preference for assimilation and a rejection of multi-culturalism as a social policy for dealing with migration. ${ }^{30}$ This policy choice was undermined by the Court, who read in Union citizenship precisely a right to be treated differently rather than the same. If anything Grunkin Paul is also striking in upholding the choice of the individual, this time employing a technique that bears striking resemblance to a mutual recognition framework. Mutual recognition as a technique is designed to preserve Member State autonomy while at

\footnotetext{
${ }^{27}$ Ibid para 84.

${ }^{28}$ Hinting that in light of the national practice of allowing Mr Wardyn to register his surname in the Polish manner, the refusal to allow Mrs Runevič-Vardyn to do so may be disproportionate. Ibid paras 92-93.

${ }^{29}$ Although note there is a conflation of constitutional identity and social cohesion through language in Vardyn.

${ }^{30}$ Garcia Avello (n 19), paras 40 and 41.
} 
the same time facilitating the creation of a single legal space with multiple inter-operable legal systems. Thus being decided on a free movement rationale and portability of an official name and civil status, Grunkin Paul obliges the home Member State to accept the consequences of the Union citizens' transnational lives and to recognize the rights they have acquired under the laws of other Member States. The motif of mutual recognition is even more apparent in the area of family reunification rights.

However, if the desire of a state to ensure social integration and assimilation is insufficient to trump an individual's or a family's right to maintain the rights they enjoy as transnational citizens, upholding the state's political identity framed in linguistic or constitutional terms, ${ }^{31}$ does appear to be a legitimate goal that can be opposed to an individual's right to 'passport' his or her status and identity. Thus the Court does not deny the continued importance of Member States as national communities, indeed it notes that their identities are protected under Union law, but endorses only certain manifestations of that community, namely political rather than social or cultural.

\section{Family Reunification}

Family reunification has been the subject of much litigation in the area of Union citizenship and for the question of reverse discrimination in particular. Two factors explain this large volume of litigation. On the one hand family life is of fundamental importance for an individual and migration has the potential to cause significant disruption to family life. On the other hand there is a significant gap between the sometimes restrictive national law in relation to family reunification and the generous Union law on the matter. The combination of these two circumstances create a very real incentive for an individual to place himself within the scope of Union law when seeking to be joined by non-national family member. Given the sometimes restrictive national practices, this incentive applies both in a host Member State but also in the citizen's 'home' Member State.

The generous family reunification provisions in Union law arise from an early recognition of human side of migration and the social importance of the family to an individual who may

\footnotetext{
${ }^{31}$ Echoing perhaps Habermas's 'constitutional patriotism' based on civil and political values rather than ethnic of cultural identities. Jurgen Habermas, 'The Postnational Constellation and the Future of Democracy' in Jurgen Habermas (ed), The Postnational Constellation (Polity Press 2001).
} 
wish to move on the one hand and the importance of family life for the integration of an individual into a host society on the other. ${ }^{32}$ Regulation 1612/68/EEC established a virtually automatic right for mobile Community workers to be joined by their immediate family in a Member State to which they move and moreover, granted extensive rights of residence, education and access to benefits to these family members. Moreover, in addition to family members who were Community nationals, the family reunification provisions of Regulation 1612/68/EEC also covered non-Community nationals or third country nationals (TCNs). Regulation 1612/68/EEC has since been replaced and updated by Regulation 492/2011/EU ${ }^{33}$ and Directive 2004/38/EC ${ }^{34}$ that retain and expand rights of family members and of family reunification.

The interpretation of these provisions by the Court of Justice reduced significantly the discretion that Member States enjoyed in relation to migration matters in the sphere of family members of Community nationals. In $M R A X$ the Court of Justice underlined the limitations on Member State's competence to control such immigration, finding that the right to family reunification stemmed directly from Community law. ${ }^{35}$ Community law laid down the conditions for enjoying those rights and Member States could not impose further conditions and requirements of proof. In Akrich however the Court appeared to backtrack on its position and shield Member States' competence in immigration matters, particularly with regard to 'first entry' into the Union (rather than secondary movement within the Union). ${ }^{36}$ Akrich permitted Member States to impose a condition of prior lawful residence on family reunification. Member States could require that a TCN family member was lawfully resident in the Union before granting a right to join the mobile Community national. Perhaps influenced by the competences arguments advanced by the Advocate General, ${ }^{37}$ the Court

\footnotetext{
32 'Whereas the right of freedom of movement, in order that it may be exercised, by objective standards, in freedom and dignity, requires that equality of treatment shall be ensured in fact and in law in respect of all matters relating to the actual pursuit of activities as employed persons and to eligibility for housing, and also that obstacles to the mobility of workers shall be eliminated, in particular as regards the worker's right to be joined by his family and the conditions for the integration of that family into the host country', Regulation 1612/68/EEC on freedom of movement for workers within the Community [1968] OJ L 257/2. This recital was replicated word for word in recital 6 of the replacement legislation, Regulation 492/2011/EU on freedom of movement for workers within the Union (codification) (Free Movement for Workers Regulation) [2011] OJ L141/1.

${ }_{33}^{33}$ Free Movement for Workers Regulation (n 32).

${ }^{34}$ Citizenship Directive (n 5).

${ }^{35}$ Case C-459/99 Mouvement contre le racisme, l'antisémitisme et la xénophobie ASBL (MRAX) v Belgian State EU:C:2002:461, [2002] ECR I-6591.

${ }^{36}$ Case C-109/01 Secretary of State for the Home Department v Hacene Akrich EU:C:2003:491, [2003] ECR I9607.

${ }^{37}$ Ibid Opinion of AG Geelhoed paras 1-9.
} 
reasoned according to a limited vision of the right of free movement based on a narrow deterrence logic. Family reunification rights were granted under Union law to remove obstacles to free movement and in particular the deterrent that might arise if an individual was to be separated from his or her family upon movement to another Member State. ${ }^{38}$ If, however, that Union citizen did not enjoy the company of his or her family before moving so the logic went, then there could be no deterrence if his or her family was not allowed entry into the new Member State. ${ }^{39}$

While no doubt welcomed by national administrations, Akrich attracted considerable academic criticism. ${ }^{40}$ The case left certain questions open, such as the problematic definition of 'prior lawful residence' and made a strange and out of place reference to Article 8 of the European Convention on Human Rights (ECHR). Furthermore, its treatment of the question of competences, presenting national immigration competences as something reserved to Member States and insulated entirely from the scope of Union law, did not appear to correspond with the traditional view of reserved national competences, according to which Member States must still exercise such competences in compliance with their obligations under Union law. ${ }^{41}$

These matters were addressed in Metock $^{42}$ in which in an unusual move, the Court of Justice explicitly reversed its position. ${ }^{43}$ Metock concerned Irish regulations adopted following the Court's judgment in Akrich, requiring TCN family members to have prior lawful residence in the Union before they would be granted a right of residence under Union law. In reversing Akrich the Court corrected its approach to national immigration competences and, more importantly for present purposes, broadened its understanding of free movement. Rather than a particularly narrow deterrence based logic deployed in Akrich focusing on the notion of less favourable treatment, in Metock the Court employed a far broader vision of what free

\footnotetext{
${ }^{38}$ Ibid paras 51-52.

${ }^{39}$ Ibid paras 53-54.

${ }^{40}$ For a selection see Chistopher Schiltz, 'Akrich: A Clear Delimitation without Limits' (2005) 12 MJ 241, Eleanor Spaventa, 'Case C-109/01 Secretary of State for the Home Department v H Akrich' (2005) 42 CML Rev 225 and Robin CA White, 'Conflicting Competences: Free Movement Rules and Immigration Laws' (2004) 29 EL Rev 385.

${ }^{41}$ See Koen Lenaerts, 'Constitutionalism and the Many Faces of Federalism' (1990) 38 Am J Comp L 205, 220 $\mathrm{ff}$ for a discussion of the absence of any reserved area of competence entirely shielded from Union law influence.

${ }^{42}$ Case C-127/08 Metock v Minister for Justince Equality and Law Reform (Metock) EU:C:2008:449, [2008] ECR I-6241. For a commentary see Catherine Costello, 'Metock: Free Movement and "Normal Family Life" in the Union' 46 CML Rev 587.

${ }^{43}$ Metock (n 42), para 58.
} 
movement entails, in particular the right of the citizen to install him or herself in the Member State of his or her choosing and to provide the appropriate conditions, including 'a normal family life', under which this could occur. ${ }^{44}$ In particular the Court focused on how discrepancies between national immigration rules could impact on the choice of a citizen to install him/herself in a particular Member State. ${ }^{45}$ This element of choice was even more explicit in the opinion of the Advocate General who found that 'the fact that Union citizens established in Ireland are unable to have their spouses join them from outside the Community is such as to undermine their free choice to reside in that Member State since it will tend to induce them to leave Ireland and to go to a State, whether a Member State or not, where they will be able to live together with their spouse' (emphasis added). ${ }^{46}$ Union citizenship therefore creates the optimal conditions under which an individual can exercise his right of mobility and moreover exercise that right in the fullest possible degree of choice. Those conditions include the right to lead a 'normal family life'. It is important to point out that this is not a question of discrimination. ${ }^{47}$ The Union citizens involved in Metock were not seeking equal treatment with Irish nationals, instead they were asking the Court to provide a special Union law regime, facilitating their choice and autonomy to move within the Union unhindered by restrictive national regulations on family reunification. It was this aspect of Union citizenship, based on free movement and choice, that founded a right for the Union to harmonise rules on family reunification for Union citizens resident in other Member States.

An additional reason for Member States' concern in this matter was the possibility of exercising this right not only in a host Member State but vis-à-vis their home Member State upon returning. This possibility arose following the case of Singh in which the Court held that a returning Community worker must enjoy 'at least the same rights of entry and residence as would be granted to him or her under Community law if his or her spouse chose

\footnotetext{
${ }^{44}$ Ibid paras 62-64.

${ }^{45}$ See especially ibid, paras 63-65: 'The refusal of the host Member State to grant rights of entry and residence to the family members of a Union citizen is such as to discourage that citizen from moving to or residing in that Member State, even if his family members are not already lawfully resident in the territory of another Member State. It follows that the Community legislature has competence to regulate....the entry and residence of nationals of non-member countries who are family members of a Union citizen in the Member State in which that citizen has exercised his right of freedom of movement, including where the family members were not already lawfully resident'

${ }^{46}$ Ibid para 9.

${ }^{47}$ Indeed the Court had already held that family reunification was classified as a social benefit within the meaning of Regulation 1612/68/EEC and hence was covered by the principle of equal treatment. See Case 59/85 Netherlands v Ann Florence Reed EU:C:1986:157, [1986] ECR 1283 for the case of equal treatment of unmarried partners.
} 
to enter and reside in another Member State. ${ }^{48}$ Member States were concerned of an erosion of their immigration competence not only in relation to Union citizens from other Member States but indeed in relation to their own nationals who could, by temporarily exercising their right of free movement, sidestep restrictive national regulations on family reunification. Indeed, this is exactly the situation that occurred in Akrich. Mrs Akrich had moved to Ireland from the United Kingdom with the stated intention of being joined by her husband and returning to the UK, carrying with her a right to be accompanied by her husband and circumventing more restrictive UK provisions.

It may be argued, as it was by the Court in Akrich, that the Union national is not in fact disadvantaged if he is not granted the right to be accompanied by his spouse upon return to the home Member State; he cannot lose a right he never enjoyed in the first place. However, what is protected in the case of returning migrants is the right of the Union citizen to maintain the rights he or she gains in a second Member State and not to be faced with the uncertainty of not knowing whether particular rights and situations acquired and developed in the host Member State can be retained upon return to the home Member State. To provide otherwise would introduce an element of instability and uncertainty that would undoubtedly deter individuals from exercising their freedom of movement. This reasoning was made especially clear in the case of Eind in which a Dutch man was joined by his Surinamese daughter while working in the UK. ${ }^{49}$ He then returned to the Netherlands and the Court found he was entitled to be accompanied by his daughter. The logic of the Court was clear Mr Eind must be allowed to retain rights he acquired in another Member State and if necessary exercise them against his own Member State. His choice to pursue a cross-border life and the social situation that might arise from living in various Member States must be protected from undue interference in both host and the home Member State. Indeed it could be argued that the same logic would protect his family life in any Member State.

This line of case law has been confirmed and expanded by the Court of Justice in the cases of $O \& B$ and $S \& G .{ }^{50}$ Both $O \& B$ and $S \& G$ concerned the third country spouses of Dutch nationals seeking residence in the Netherlands. In $O \& B$ two Dutch nationals had resided

\footnotetext{
${ }^{48}$ Case C-370/90 The Queen v Immigration Appeal Tribunal and Surinder Singh EU:C:1992:296, [1992] ECR I-4265 para 23.

${ }^{49}$ Case C-291/05 Minister voor Vreemdelingenzaken en Integratie v R. N. G. Eind EU:C:2007:771, [2007] ECR I-10719.

${ }^{50}$ Case C-456/12 O \& B v Minister voor Immigratie, Integratie en Asiel EU:C:2014:135 and Case C-457/12 Sv Minister voor Immigratie, Integratie en Asiel EU:C:2014:136.
} 
temporarily (for a couple of months in the case of $O$ ) and sporadically (at weekends in the case of $B$ ) in other Member States with their third country national spouses. They returned to their home Member State after a limited period of time abroad and sought to bring their spouses with them. In $S \& G$ the Dutch nationals resided in the Netherlands but worked and performed services in another Member State. They were variations on the 'frontier worker'; one a frontier worker as commonly understood, living in the Netherlands but working for a Belgian company in Belgium; the other a part-time cross-border service provider, living and employed in the Netherlands but spending approximately thirty per cent of his working time in Belgium as part of his job. Thus while all four were Dutch nationals living in the Netherlands, all claimed some cross-border connection through either temporary stays abroad or through exercising a cross-border economic activity.

In $O \& B$ the Court restated its position that free movement includes the freedom to return to the host Member State. ${ }^{51}$ It was firm in upholding its findings in Singh and Eind and in extending this reasoning to the situation of non-economically active Union citizens relying on Article 21(1) TFEU. In particular it emphasised the need to guarantee that a Union citizen will be able to 'continue the family life which he created or strengthened in the host Member State'. ${ }^{52}$ However, this only referred to family life that was created or strengthened in the context of 'genuine', 'settled' residence in the second Member State to be determined by analogy to the categories of residence found in Directive 2004/38/EC. ${ }^{53}$ The Court therefore excluded the possibility of a family life being created or strengthened on the basis of mere temporary residence. In $S \& G$ the Court confirmed the possibility that cross-border economic activity could entail certain rights of family reunification, while at the same time indicated that this would only arise in limited circumstances. Furthermore, given the facts of the case, it felt able to limit its reasoning to workers under Article 45 TFEU and declined to rule on the impact of Union citizenship under Article 21 TFEU. Restrictions on a Union citizen worker's family life must be such as to discourage 'the worker from effectively exercising his rights'. ${ }^{54}$ However, the desirability of a particular familial arrangement, such as child care by a mother-in-law, is not sufficient in itself to establish a right of residence for a family member. ${ }^{55}$

\footnotetext{
${ }^{51} O \& B($ n 50) paras 47-59.

${ }^{52}$ Ibid para 49.

${ }^{53}$ Ibid para 56.

${ }^{54} S$ (n 50) paras 42-43.

${ }^{55}$ Ibid para 43.
} 
$O \& B$ and $S \& G$ represent the reality of modern migration as a circulatory phenomenon whereby individuals move back and forth between Member States over the course of their lives, or even during the course of their working day, as in the case of frontier workers. It presents Union citizenship as a status facilitating this form of migration and the choice to pursue lives across various borders at different stages of life, not simply in migrating from one state to another but in enjoying a broader choice across the territory of the Union, unhindered by national differences in laws. This implies not only the right to move from one state to another, but back again and indeed the positive choice and freedom of where to live. The right of the Union citizen to pursue his life in the Member State of his choosing was even more explicit in the joint Opinion AG Sharpston delivered for both cases. She pointed out on a number of occasions that a right to freedom of movement entailed a right to remain in the home Member State. Echoing the Court's finding in Metock that citizens have a general freedom of movement that implies a choice. '[I]t might be said that such a measure results in more movement. However, whilst facilitating free movement may well be an objective of Article 21(1) TFEU, imposing free movement is not. Rather, EU citizens are guaranteed the right to move and reside freely within the European Union. If a measure is likely to affect the EU citizen's free choice to exercise that right, then it is a restriction which, unless justified, is contrary to Article 21(1) TFEU'(emphasis in original). ${ }^{56}$

As with the 'name' cases, the family reunification cases also clearly demonstrate that free movement is not simply a question of a right to move to and settle definitively in another Member State, but also implies a general right, spread over the course of a life time, to move around the territory of the Union and to avail of the expanded possibilities offered in various Member States. Firstly, as Metock demonstrates it is a choice that is offered to the Union citizen as an inherent part of that status and that choice must be facilitated by the creation of optimal conditions, especially conditions of 'normal family life'. Note that this is only partially, and secondarily, an integration or non-discrimination based logic. The reasoning of the Court in Metock is based almost entirely on free movement. It is the choice contained in Union citizenship that grants Union law the competence to regulate family reunification,

\footnotetext{
${ }^{56} O \& B$ (n 50) and $S$ (n 50), Opinion of AG Sharpston, para 89. Similarly '[w] hat matters is the freedom to choose whether to move or not to move. A measure that imposes movement restricts that choice. It is therefore contrary to Article 21(1) TFEU (emphasis in original).' (para 134). Interestingly the AG also finds that EU law also permits an individual to exist and live across borders, not being obliged to remain in a single state. 'There is no general rule of EU law whereby residence in one Member State precludes concurrent residence in another Member State.' (para 104).
} 
even instances of so called 'first entry'. Secondly, Singh, Eind and $O \& B$ provide that those situations that arise in one Member State must be accommodated in other Member States, including and especially the Member State of origin. As with a name or civil status, a family life 'strengthened or created' in one Member State must be portable. Family reunification for Union citizens is not a mutual recognition regime as we traditionally understand it, indeed that is exactly what was at stake in Akrich and Metock, in the sense that it is based not on national rights or national laws but on Union rights created on foot of the harmonisation contained in the Treaty articles on free movement and implemented in Directive 2004/38/EC. Nonetheless, the result of Eind and $O$, in obliging Member States to accept that the 'vested rights" ${ }^{, 57}$ (albeit this time Union rights) acquired by virtue of free movement must be recognised in the host Member State. The result points towards a vision of Union citizenship presented by Preuß in 1995:

'by creating the opportunity for the citizens of the Member States of the European Union to engage in manifold economic, social, cultural, scholarly and even political activities irrespective of the traditional territorial boundaries of the European nation-states, European citizenship helps to abolish the hierarchy between the different loyalties... and to allow the individuals a multiplicity of associative relations without binding them to a specific nationality. In this sense, European citizenship is more an amplified bundle of options within a physically broadened and functionally more differentiated space than a definitive legal status. $^{, 58}$

It will be noted however $O \& B$ was not so clear-cut so as to permit uninhibited movement based on a rootless and continual movement. Rather, only family life that was formed on the basis of residence in the host Member State in conformity with conditions of economic activity or self-sufficiency: 'evidence of settling there' counts. ${ }^{59}$ The Court therefore excluded stays of less than three months and subjected stays of longer than three months to the conditions contained in Directive 2004/38/EC. In other words only family life created or strengthened on the basis of settled or 'genuine' residence could be retained upon return to the host Member State. Applying this extra condition to family reunification in the home state points to the other aspect of Union citizenship as a transnational status that is at times

\footnotetext{
57 A term found in private international law see Jan-Jap Kuipers, 'Cartesio and Grunkin Paul: Mutual Recognition as a Vested Rights Theory based on Party Autonomy in Private Law' 2 EJLS 66.

${ }^{58}$ Ulrich Preuß, 'Problems of a Concept of European Citizenship' (1995) 1 ELJ 267, 280.

${ }^{59} O \& B($ n 50) para 53.
} 
in tension with the autonomy of Union citizens: citizenship as a status of integration in the society of the host Member State.

\section{Transnational Citizenship as a Status of Integration}

Union citizenship offers individuals the right to move around and enjoy the opportunities presented by a variety of economies and cultures. However, perhaps more importantly it offers Union citizens the right become part of, to integrate into, the society of other Member States. This dimension of Union citizenship is intimately bound up with the principle of nondiscrimination but is facilitated by free movement. Equal treatment is both the catalyst or the means by which integration takes place and also the consequence of this process. In terms of a legal status this feature of Union citizenship has been developed by both the Court of Justice and by the Union legislature in a largely collaborative endeavour over the past two decades. While for the most part this principle has operated in favour of immigrant Union citizens in the host Member State, it has also been used in limited circumstances for strengthening the rights of emigrant Union citizens vis-à-vis their home Member State. In the concept of social integration the Court of Justice and the Union legislature have elaborated a criteria, in addition to that of nationality, for attaching individuals to particular national communities with the European Union and for allocating responsibilities amongst states for those individuals. The result has been the establishment of an additional principle of belonging in the context of changing social and economic ties between individuals and societies in a set of political communities.

\section{Union Citizenship as a Status of Integration and the Court of Justice}

Union Citizenship as integration is closely tied to the principle of non-discrimination on grounds of nationality now found in Article 18 TFEU. While the principle is of general application across the Treaty and arises in a more specific application in the provisions on the free movement of persons in the internal market ${ }^{60}$ it emerged as a defining component of Union citizenship in the case of Martiniz Sala. ${ }^{61}$ The relationship between the principle of non-discrimination and Union citizenship is symbiotic. Non-discrimination on the grounds

\footnotetext{
${ }^{60}$ Agustín José Mendéz, 'European Citizenship after Martiníz Sala and Baumbast: Has European Law become More Human but Less Social?' in Miguel Poirias Maduro and Loic Azoulai (eds), The Past and Future of EU Law (Hart 2010).

${ }^{61}$ Martinez Sala (n 4).
} 
of nationality soon formed the core of Union citizenship and gave rise to the first series of cases that put 'flesh on the bones' of a status whose importance had until then been considered limited. ${ }^{62}$ At the same time, the application of the principle of non-discrimination on the grounds of nationality, in theory limited to the scope of the Treaty, was broadened considerably with the advent of Union citizenship. The personal scope of the principle was especially widened to include all lawfully resident Union citizens in another Member State. ${ }^{63}$ Furthermore, given the expansive range of Union law, it was possible to find some exercise of Union competence in a particular area with increasing ease, thereby bringing the situation within the material scope of the prohibition of non-discrimination on grounds of nationality. ${ }^{64}$

The impact of the principle was felt particularly in the field of social benefits, which were subject to a variety of qualifying conditions determining the personal limits of financial solidarity, generally mapped onto the national community. ${ }^{65}$ In a series of cases in the late 1990s and early 2000s the Court began to redraw these boundaries of solidarity based on the concept of Union citizenship and the principle of equal treatment. In time the extent to which an individual had a 'real link' with the society of a particular Member State became the governing principle for determining the extent of equal treatment a citizen was entitled to and hence the extent of the financial solidarity owed that citizen by host Member States.

Martinez Sala established the principle that all Union citizens lawfully resident in another Member State were entitled to equal treatment in all matters that fell within the scope of Union law. ${ }^{66}$ Mrs Martinez Sala was seeking a child-rearing allowance and was refused on the grounds that she did not hold a valid residence permit. She was however lawfully resident in Germany on the basis of an international agreement. As a Union citizen lawfully resident in another Member State she fell within the personal scope of Article 18 TFEU (then Article 6 EC). Child rearing allowance was a social benefit within Article 7 of Regulation

\footnotetext{
${ }^{62}$ To borrow an expression from Síofra O'Leary in Síofra O'Leary, 'Putting flesh on the bones of European Union Citizenship' (1999) 24 EL Rev 68.

${ }_{63}^{63}$ Martinez Sala (n 4) paras 46-49.

${ }^{64}$ For a particularly tendentious link see Case C-60/00 Mary Carpenter v Secretary of State for the Home Department EU:C:2002:434, [2002] ECR I-6279.

${ }^{65}$ Michael Dougan, 'The Spatial Restructuring of National Welfare States within the European Union: the contribution of Union Citizenship and the relevance of the Treaty of Lisbon.' in Ulla Neergaard, Ruth Nielson and Lynn Rosebury (eds), Integrating Welfare Function into EU Law: From Rome to Lisbon (DJOF Publishing 2009).

${ }^{66}$ Martinez Sala (n 4).
} 
1612/68/EEC and fell within the material scope of Article 18 TFEU. As German nationals did not need to satisfy the condition of holding a valid residence permit, it was considered a discriminatory practice on grounds of nationality and as it fell within the material and personal scope of Article 18 TFEU, was considered unlawful.

If Martinez Sala established the legal principle, Grzelczyk provided the language and rhetoric with which that principle could be developed and given further meaning. $\mathrm{Mr}$ Grzelczyk, a French national, was seeking a minimum subsistence allowance in Belgium (the 'minimex') after a number of years supporting himself as a student. He was refused on the basis that he did not fall within the scope of Regulation 1612/68/EEC. A Belgian in a similar situation would have been entitled to the minimex. The Court reiterated its findings from Martinéz Sala that all lawfully resident Union citizens were entitled to rely on Article 18 TFEU (then Article 6 TEC). The minimex fell within the scope of Regulation 1612/68/EEC and hence Union law. Accordingly the refusal to grant the minimex to $\mathrm{Mr}$ Grzelczyk was discriminatory and contrary to a combined reading of the principle of nondiscrimination and Union citizenship. Perhaps as important as the finding itself was the language the court used and how it revealed its vision for Union citizenship. In the now ubiquitous phrase the Court declared that 'Union citizenship is destined to be the fundamental status of nationals of the Member States, enabling those who find themselves in the same situation to enjoy the same treatment in law irrespective of their nationality, subject to such exceptions as are expressly provided for' ${ }^{67}$ Furthermore, the fact that Union citizenship had given a new dimension to the principle of non-discrimination appeared to be confirmed by the Court's statement that 'Article 6 must be read in conjunction with the provisions of the Treaty concerning citizenship of the Union in order to determine its sphere of application. ${ }^{68}$ Moreover, by providing that students must not become an unreasonable burden, the legislature had in fact accepted 'a certain degree of financial solidarity between nationals of a host Member State and nationals of other Member States. ${ }^{69}$

Martinez Sala established that the principle of equal treatment was in theory applicable to all Union citizens lawfully resident in other Member States. Grzelczyk, coined the prophetic

\footnotetext{
${ }^{67}$ Grzelczyk (n 4) para 31.

${ }^{68}$ Ibid para 30.

${ }^{69}$ Ibid para 44. This finding in relation to the minimex, including the fact that recourse to social assistance could not automatically lead to loss of an individual right of residence, was again confirmed in Case C-456/02 Michel Trojani v Centre public d'aide sociale de Bruxelles (CPAS) EU:C:2004:488, [2004] ECR I-7573.
} 
phrase that Union citizenship was 'destined to become the fundamental status of nationals of the Member States' and tied this to 'the same treatment in law irrespective of their nationality' thereby tightening the link between the principle of non-discrimination and the status of Union citizenship and found that Member States had accepted a certain degree of solidarity with nationals of other Member States, aka Union citizens. ${ }^{70}$ The exact extent of this solidarity was outlined in the case of Bidar ${ }^{71}$ in which a French student in the UK was found to be discriminated against by a system for awarding subsidised loans for student fees. While excluded from the scope of secondary legislation, Mr Bidar was able to rely directly on the Treaty. The Court accepted that some conditions on the award of such assistance could be justified by the need to limit it 'to students who have demonstrated a certain degree of integration into the society of [the host] State. ${ }^{72}$ However that link was specifically a social one, with the Court excluding the possibility of requiring an economic link or one with the employment market. ${ }^{73}$ The application of the conditions necessary to ensure such a link had to be conducted in a proportionate manner, in other words such conditions needed to be both necessary to achieve the objective of ensuring a genuine link with the society of the host Member State and not to go beyond what was necessary. A certain period of residence was indicative of a certain degree of integration but a system, such as that in the case of Bidar, whereby it was impossible for a non-UK national to achieve settled status while a student, could not be justified. ${ }^{74}$

On the basis of the principle of non-discrimination, the status of Union citizenship, the principle of proportionality and the concept of a 'real link' to the society of the host Member State, the Court has engineered a transnational status based on the concept of integration. Solidarity between individuals is determined by their 'real link' manifested by social connections to a particular Member State. The degree of social integration therefore determines the duties owed by a Member State to a particular individual. This in effect opens up national social welfare systems to sufficiently integrated nationals of other Member States. It strikes a balance between enlarging the potential scope of solidarity or community and the need to respect the natural limits of a system of solidarity that still operates, and is legitimised at the level of national communities. The solution is the creation of a status that

\footnotetext{
${ }^{70}$ Grzelczyk (n 4), para 44.

${ }^{71} \operatorname{Bidar}(\mathrm{n} 4)$.

${ }^{72}$ Ibid para 57.

${ }^{73}$ Ibid para 58.

${ }^{74}$ Ibid para 61.
} 
can trigger a process of integration on the basis of which equal treatment and solidarity is extended to Union citizens with 'real links'. Communities of solidarity remain essentially national in scope, what Union citizenship has achieved is a reconfiguration of the boundaries of those national communities to take into account the status of Union citizenship.

The process of social integration is generally seen as placing obligations and responsibilities on the host Member State, to facilitate integration and grant an ever-increasing right to equal treatment. Recent cases have tended to call this unidirectional process that emphasises the role of the state rather than the individual in the integration process into question. On the one hand, the court has increasingly viewed the economic conditions for residence contained in Directive 2004/38/EC as reflecting 'qualitative' elements to the integration process, to be met by the individual Union citizen. ${ }^{75}$ Recent caselaw of the Court of Justice, in particular Dano, has placed the issue of economic activity or contribution even more squarely on the agenda. ${ }^{76}$ This turn towards imposing 'qualitative' conditions on integration and placing more emphasis on the role of the individual in that process is found not only in the area of welfare benefits but perhaps even more starkly in the exercise of the public policy exception by Member States where, using the language of criminal law, it takes a more normative and value-laden tone, a matter explored in chapter 4.

The use of the 'real link' and the concept of social integration also operates to a lesser extent in the other direction, enabling individuals to 'export' benefits to other Member States to the extent that they retain sufficient links with the society of the home Member State. In both Nerkowska ${ }^{77}$ and Stewart ${ }^{78}$ the Court found that Union citizenship allowed individuals to retain benefits owed them by virtue of their past association with a particular Member State when moving to another Member State, based on the particular characteristics of the benefits in question and the links of those individuals with the home Member State. The result is an example of the complementarity of the principles of autonomy and integration. Just as family reunification, is used to facilitate social integration, the concept of social integration

\footnotetext{
${ }^{75}$ Case C-325/09 Secretary of State for the Home Department v Maria Dias EU:C:2011:498, [2011] ECR I6387.

${ }^{76}$ Case C-333/13 Elisabeta Dano \& Florin Dano v Jobcenter Leipzig EU:C:2014:2358. For an analysis see Daniel Thym, 'The Elusive Limits of Solidarity: Residence Rights of and Social Benefits for Economically Inactive Union Citizens' (2014) 52 CML Rev 17.

${ }_{77}$ See Case C-499/06 Halina Nerkowska v Zakład Ubezpieczeń Spolecznych Oddziat w Koszalinie EU:C:2008:300 [2008] ECR I-3993.

${ }^{78}$ Case C-503/09 Lucy Stewart v Secretary of State for Work and Pensions EU:C:2011:500, [2011] ECR I-6497.
} 
is here used to facilitated further autonomy. Union citizenship therefore not only disrupted the personal boundaries of national welfare systems by allowing non-nationals to gain equal treatment in host Member States but also the territorial boundaries by allowing individuals who retain sufficient links with Member States to maintain rights. The net result is a system whereby individuals are increasingly associated with a particular state and community based not only on ties of nationality but also social connections. This tendency to use the concept of 'social integration', alongside nationality, to allocate responsibility for particular individuals to particular Member States, is also found in the area of sentencing, where it is reinforced by the penological principle of rehabilitation, as explored further in chapter 3.

\section{Union Citizenship and as a Status of Integration and the Legislature}

This vision of Union citizenship as a status of integration was taken up by the Union legislature and made the leitmotif of the Citizenship Directive. Indeed, the development of the concept of a 'real link' by the Court of Justice occurred in parallel with the elaboration of the Citizenship Directive. ${ }^{79}$ While on one level a unifying instrument, applying a single instrument and certain common principles to all Union citizens in another Member State, the Directive still categorises citizens according to the activity they undertake and the length of time they spend in a host Member State. The major innovation of the Directive is the status of 'permanent resident', which is intended to be 'a genuine vehicle for integration into the society of the host Member State in which the Union citizen resides' ${ }^{80}$ This is achieved by presenting Union citizenship as a progressively strengthened status. Short stays attract a minimum of rights. Initial stays of up to five years are subject to conditions but nonetheless include an extensive right to equal treatment. ${ }^{81}$ Stays of more than five years entitle the Union citizen and his family to 'permanent residence'. A permanent resident enjoys almost complete equal treatment and is no longer subject to conditions of residence, such as paid employment or sufficient resources. This picture of protection and rights increasing in parallel over time is also found in the provisions relating to expulsion. In Article 28 of the Directive the level of threat that needs to be established in order to justify the expulsion of a Union citizen increases with the length of his residence. ${ }^{82}$

\footnotetext{
${ }^{79}$ Evident from the timing of the Bidar judgment, handed down after the adoption of the Citizenship Directive but before its transposition deadline.

${ }^{80}$ Citizenship Directive (n 5) recital 18.

${ }^{81}$ Ibid art 24.

${ }^{82}$ Ibid art 16(1).
} 
The purpose of the Directive is to create a supranationally guaranteed and generous status of immigration, with wide ranging rights of employment, equal treatment, residence and family reunification explicitly based on the concept of social integration. Integration in immigration law is normally considered a condition to be applied to those individuals who may be granted a right to stay on a more permanent basis. However, the entire Directive is organised along a trajectory of increasing links and rights of the Union citizen with the ultimate goal of the Union citizen's status approaching that of a national and becoming a quasi-member of the community. ${ }^{83}$ If it is an immigration status, it is one that is orientated from the very beginning towards virtually full membership of the immigrant over time. This view of the Directive as being organised towards the acquisition of permanent residence, intended to be a 'genuine vehicle of integration in the society of the host Member State', has been endorsed on many occasions by the Court of Justice. ${ }^{84}$

In its interpretation of the Directive, the Court has engaged actively with its underlying philosophy, reading it in light of its telos of integration and has drawn on its provisions to inform its own jurisprudence. The Court has consistently interpreted provisions relating to permanent residence in light of its goal of both facilitating and being the result of a process of integration. In Lassal this underlying objective of Article 16 of Directive 2004/38/EC was used as an argument, amongst others, to apply the five year qualifying period retrospectively, in that case to allow a French woman to count periods of residence that occurred prior to transposition of the directive when acquiring the right of permanent residence. ${ }^{85}$ More harmful for the position of the individual but still based on the concept of integration, in Onuekwere the Court went even further and excluded periods spent in prison from the calculation of the five year period on the basis that such periods could not be considered periods in which the individual was engaged in a process of integration with the host

\footnotetext{
${ }^{83}$ In this sense it could be described as a form of denizenship. However, unlike traditional forms of denizenship based on national law, Union citizenship under the Directive is one that is explicitly tailored to this end and indeed forms the overall theme of the Directive. For an analysis of denizenship as it emerged in European states see Tomas Hammar, Democracy and the nation state: aliens, denizens and citizens in a world of international migration (Aldershot 1990). For use of the concept in the context of the EU see Neil Walker, 'Denizenship and Deterritorialization in the EU' LAW 2008 Oxford Journal of Legal Studies, No 4, 2005.

84 Joined Cases C-424/10 and C-425/10 Tomasz Ziolkowski \& Barbara Szeja \& Oths v Land Berlin (Ziolkowski) EU:C:2011:866, [2011] ECR I-14035 para $37 \mathrm{ff.}$

${ }^{85}$ Case C-162/09 Secretary of State for Work and Pensions v Taous Lassal EU:C:2010:592, [2010] ECR I-9217 para 37.
} 
society. ${ }^{86}$ Indeed, the Court of Justice has not only interpreted the award of permanent residence as a form of reward for properly integrated Union citizens, but has also interpreted the residence conditions of the Directive as those that ensure or provide for integration. In Ziolkowsi the Court of Justice accepted that while 'legal residence' need not necessarily be residence explicitly based on the Directive, it must comply with the substantive conditions of the Directive, in particular those found in Article 7(1). ${ }^{87}$ More recently in $O \& B$ the Court was even more explicit in characterising the conditions contained in the Directive for periods of more than three months as those under which a Union citizen becomes 'settled' and enjoys 'genuine residence'. ${ }^{88}$ Not only does the Directive aim towards the integration of the Union citizen, but it provides the conditions under which such integration can take place.

\section{Union Citizenship as a Transnational Status Between Autonomy and Integration}

The defining feature of Union Citizenship as a legal status is therefore the ability of individual Union citizens to enjoy the expanded range of opportunities offered by a wider geographical space containing a plurality of legal systems and political communities. Two features in particular can be discerned in the case law and the legislation. On the one hand individual autonomy is strengthened by an emphasis on free movement in particular. Individuals may move to another Member State, there establish a life, avail of the legal, economic and social advantages available in other Member States and acquire rights in those States. Union citizenship allows these rights and personal situations and civil statuses acquired in one Member State to be carried or, in the words of AG Sharpston, 'passported' to other Member States. ${ }^{89}$ In many instances the analogy with mutual recognition is striking and while normally we understand mutual recognition to mean the recognition of national regulations in the case of the internal market or judgments in the case of the Area of Freedom, Security and Justice, ${ }^{90}$ in this field it is the mutual recognition of duly acquired rights based on both national and Union law. The result is that bundles of rights and personal situations developed by Union citizens by leading transnational lives must be able to follow

\footnotetext{
${ }^{86}$ Case C-378/12 Nnamdi Onuekwere v Secretary of State for the Home Department EU:C:2014:13. See also Case C-400/12 Secretary for State for the Home Department v MG EU:C:2014:9. See further ch 3.

${ }^{87}$ Ziolkowski (n 84) paras 46-47.

${ }^{88} O \& B$ (n 50).

${ }^{89}$ Joint Opinion of AG Sharpston for ibid and $S$ (n 50) para 95.

${ }^{90}$ See generally Christine Janssens, The Principle of Mutual Recognition in EU Law (OUP 2013).
} 
them across borders. In this picture the sphere of operation of Union citizenship is the territory of the Union as a whole, albeit composed of various individual national territories amongst which the Union citizen can effectively pick and chose depending on his personal choices, means and life circumstances. ${ }^{91}$

Another distinct characteristic of Union citizenship and one that has been more prevalent in the case law and especially in legislative activity is Union citizenship as a status of integration in another Member State. The emphasis in this vision is not a footloose, cosmopolitan individual toing and froing throughout the Union disregarding national regulations and provisions that may hinder him. This Union citizen is a more familiar image in the history of migration, an individual that moves to another Member State with the intention of settling there. In this capacity he enjoys a series of rights and a status progressively strengthened along an axis of social integration. In this field the Court of Justice and the Union legislature have entered into a fruitful and close collaboration. The central concept of a 'real link' was elaborated almost simultaneously by both institutions and in subsequent developments the Court has borrowed and exported elements of the Directive to add detail to rights derived directly from the Treaty. Similarly, the notion of social integration has driven its interpretation of key concepts in the Directive, in particular the definition of residence and the acquisition of permanent residence status. The concept of social integration and its use within the context of Union citizenship has established a new principle, alongside the traditional principle of nationality, for allocating individuals to particular political communities. This has been most striking in the field of social benefits but has lately been exported to other areas, including as we shall see the field of criminal law and in particular imprisonment.

The two aspects of Union citizenship are intermingled at various points in the law and at times tend to support and reinforce each other. They are not necessarily mutually exclusive and in certain circumstances they can be considered complementary, particularly in today's world of increased mobility and more changeable life circumstances. Sometimes aspects of

\footnotetext{
91 'le sujet actif renaît comme sujet auto-organisé: acquérant non seulement le droit de s'intégrer d'une manière aussi complete que possible dans les différentes sociétés composant l'Union, amis aussi la faculté d'accéder aux biens communs et aux structures collectives dans les autres Etats membres et, en outré, la liberté de s'organiser et de choisir son style de vie, ses lieux et ses régimes de vie parmi les possibilities offeretes sur le territoire de l'Union. L'autonomie se transforme: c'est une capactié d'être en mesure d'organiser sa vie, conformément à une idée de la justice de nature "aspirationnelle" (emphasis in original). Loic Azoulai, 'L'autonomie de l'individu européen et la question du statut' EUI Working Papers LAW 2013/14.
} 
the principle of autonomy, such as the right to carry a family life across borders, is used to strengthen integration; at other times the concept of social integration is used to advance the autonomy of Union citizens by allowing them to export benefits. $O \& B$ and $S \& G$, perhaps represent within the same set of judgments the balance between autonomy and integration. Autonomy here is used to facilitate potential integration, rights of return for family members are granted so as not to deter initial free movement to a host Member State for the purposes of settling there, or at least spending more than a nominal period of time.

Yet, fundamentally the principles of autonomy and integration are in tension and offer competing visions of the Union citizen and his or her relationship with the societies of Member States; one representing a liberal cosmopolitan philosophy, the other a rooted communitarian image. They represent competing visions of both the Union citizen and the notion of community in the Union. At the level of the individual, Union citizenship as social integration tends to promote a rooted, socially constituted individual, living within and as part of particular society. Union citizenship as autonomy promotes a looser, more individualised character; self-determining and not bound to a particular society, a quasi (and regionally bounded) cosmopolitan citizenship. ${ }^{92}$ Individuals are not required, and indeed are protected from, a requirement to choose one particular Member State in which to live their lives and to integrate within the society of that state. On the level of community the concept of social integration privileges the national. National communities are understood as being the primary location for the development and existence of social life between individuals and moreover, they are deemed to be quasi-exclusive; one integrates into another particular Member State's society and becomes part of that society, enjoying its rights and cultural space. Union citizenship as autonomy tends to privilege a Union-wide existence, in which individuals are 'offered' a broader space of different opportunities and to pick and choose the different components of their life from amongst those opportunities - a kind of eclectic, á la carte political space. Though the operation of autonomy, a certain supranational space emerges that individuals occupy as autonomous and self-constituting.

At times, the tensions between these two visions erupt in the caselaw. In Garcia-Avello there was a direct tension between treating the Garcia-Avello children as quasi-Belgian or as cosmopolitan Europeans; between the choice of the parents as a transnational family and the

\footnotetext{
${ }^{92}$ See Everson, 'A Very Cosmopolitan Citizenship: But who Pays the Price?' (n 15).
} 
equal treatment of the children vis-à-vis Belgian society and between the Union as a collection of individual national communities or as a broader space of movement. ${ }^{93}$ In $O \&$ $B$, while the Court tended to strike a balance between integration and free movement or autonomy, it was an awkward balance. There is no logical, necessary link between an individual having 'genuine settled' residence of a certain period of time and acquiring rights capable of being passported and enjoyed throughout the Union. What imposing such a requirement does achieve is to compromise the autonomy of Union citizens in leading transnational lives in the interests of buttressing social coherence in the context of Member States.

Both do however enable the Union citizen to live across borders, either across multiple and changing borders in the case of citizenship as autonomy or across a single border and entry into the society of another Member State in the case of citizenship as integration. Combined they reflect Union citizenship as a transnational status. It establishes rights for the individual who moves across borders and enjoys the fruits of multiple national communities and is principally exercised against other Member States and to a limited extent against the Member State of nationality where this is necessary to secure the reality of the transnational life. It is the ability to both move throughout and around the Union and to have the option to settle in other Member States that together make-up Union citizenship as a transnational status. In order to be fully achieved it entails both the right to move to, settle and eventually receive equal treatment as a virtually full member of the host society and the right to carry an ensemble of rights and a civil status throughout the territory of the Union.

\section{Union Citizenship as a Supranational Status}

Union citizenship is primarily a transnational status. It entails a right to enjoy the various fruits and opportunities offered by an expanded economic, social and political space, including the right to settle and integrate into another society of a Member State. It is a supranational guarantee of rights exercised at a national level, placing Union citizens in privileged positions vis-à-vis Member States, primarily other Member States, but also in limited circumstances their 'home' Member State. It alters the relationship between individuals and Member States and the political communities they represent by obliging

\footnotetext{
${ }^{93}$ Garcia Avello (n 19).
} 
Member States to open their borders and societies to include other Union citizens and to adapt their administrative practices and regulations to facilitate cross-border movement. I have termed these two aspects of transnational citizenship as representing principles of 'integration' and 'autonomy' respectively, principles that are distinct but complementary and inter-locking. For the most part Union citizenship does not establish direct legal relations between the individual and the Union as a whole. Until recently it did not establish relations between Union citizens directly nor did it reflect a 'European' community of citizens at a supranational level independent of national membership. ${ }^{94}$ However, recent developments in the jurisprudence of the Court of Justice have questioned this picture of the purely transnational nature of Union citizenship. In a series of cases the Court of Justice has established the autonomous character of Union citizenship, emphasising not a relationship between Member States and individuals but a direct legal relationship between individuals and the supranational legal order by virtue of the status of Union citizenship. However, while asserting the existence of such an autonomous legal status, the Court has, as of yet, been reluctant to specify the precise content and implications of such a status in terms of rights and duties.

\section{The Establishment of an autonomous Supranational Status: Rottmann and Zambrano.}

In a pair of cases in 2010 and 2011 the Court of Justice outlined a theory of Union citizenship that included an autonomous status, linking the individual directly with the Union legal order. This was based not on Article 21 TFEU and the rights of free movement and residence but directly on Article 20(1) TFEU establishing Union citizenship.

Union citizenship is a derived status. It is acquired through holding the nationality of a Member State, the acquisition of which is determined solely by that Member State. ${ }^{95}$ Nationality laws, defining who is and who is not a member of the national political community and hence indirectly the community itself, can be said to lie at the heart of

\footnotetext{
${ }^{94}$ Indeed this sentiment might be seen behind the rules of acquisition of Union citizenship and the language used in the Treaty ('Citizenship of the Union shall be additional to and not replace national citizenship' [emphasis added]) and in the unilateral declaration of Denmark following the Edinburgh Council Meeting ('Nothing in the Treaty on European Union implies or foresees an undertaking to create a citizenship of the Union in the sense of citizenship of a nation-sate'). See Conclusions of the Presidency Edinburgh, December 12, 1992 Annex 3 Unilateral Declaration of Denmark

${ }^{95}$ Article 20(1) TFEU: 'Every person holding the nationality of a Member State shall be a citizen of the Union. Citizenship of the Union shall be additional to and not replace national citizenship.') ibid.
} 
national sovereignty. ${ }^{96}$ The derived nature of Union citizenship is beyond doubt, as is the exclusive competence of Member States in awarding nationality. However, in Rottmann the Court of Justice found that when withdrawing nationality from an individual, Member States were required to apply general principles of Union law and in particular undertake a proportionality assessment. This involved taking into account the impact on the individual of the loss of his rights under Union law and the legitimate interests the Member State may have in depriving him of those rights. ${ }^{97}$ It arrived at this conclusion by reading Union citizenship as an autonomous status under Union law that generates its own rights. The decision of a Member State to withdraw it must therefore be subject to review under the principles of Union law. ${ }^{98}$

Union citizenship, while linked with nationality in terms of possession, in fact constitutes a separate and parallel status established under Union law and subject to its requirements. It establishes a relationship between Europeans, constituting a new community that builds on national communities, at a supranational level. Nationality and Union citizenship 'are both inextricably linked and independent'. ${ }^{99}$ This vision of Union citizenship and its relationship with nationality is eloquently put in the Opinion of AG Maduro. Nationality and Union citizenship are linked in their mode of acquisition and indeed loss and as a consequence in the nature of the forms of membership they represent. Indeed it is the 'miracle of Union citizenship' that 'it strengthens the ties between us and our States (in so far as we are European citizens precisely because we are nationals of our States) and, at the same time, it emancipates us from them (in so far as we are now citizens beyond our States). Access to European citizenship is gained through nationality of a Member State, which is regulated by national law, but like any form of citizenship, it forms the basis of a new political area from which rights and duties emerge, which are laid down by Community law and do not depend

\footnotetext{
${ }^{96}$ For an illustration of Member State discretion in this respect see Case C-192/99 The Queen and Secretary of State for the Home Department, ex parte: Manjit Kaur EU:C:2001:106, [2001] ECR I-1252. Indeed this very insistence on maintaining exclusive national competence in this area has led to knock on effects for other Member States, ironically limiting their discretion in certain areas, in particular in recognising the underlying nationality of Union citizens once granted by a Member State see Case C-369/90 Mario Vicente Micheletti and others v Delegación del Gobierno en Cantabria EU:C:1992:295, [1992] ECR I-4239, Case C-138/02 Collins v Secretary of State for Work and Pensions EU:C:2004:172, [2004] ECR I-2803 and Case C-200/02 Kunqian Catherine Zhu, Man Lavette Chen v Secretary of State for the Home Department, EU:C:2004:639, [2004] ECR I-9951.

${ }^{97}$ Case C-135/08 Janko Rottmann v Freistaat Bayern EU:C:2010:104, [2010] ECR I-1449.

${ }^{98}$ Ibid para 48.

${ }^{99}$ Ibid.
} 
on the State. ${ }^{100}$ It is through nationality that one becomes a Union citizen and accordingly it is through membership of a national community of a Member State that one becomes a member of a supranational European community. Yet once one has become such a member, it is an autonomous and independent status.

The implications of Rottmann became clearly apparent in the case of Zambrano. ${ }^{101}$ Zambrano is noted for founding a right of residence for Union citizens and certain members of their families even in their home state under certain (unclear) circumstances. In modifying the so called 'purely internal rule' and the question of reverse discrimination ${ }^{102}$ it can be added to the long list of decisions protecting the family life of Union citizens and transforming family members into 'quasi-citizens' ${ }^{103}$ However, for present purposes the real interest in the decision lies in the hermeneutic technique used by the Court and in particular its reliance on the independent status of Union citizenship to justify its decision. ${ }^{104}$ Quickly finding that the rights of free movement and residence found in Article 21 TFEU and the relevant secondary legislation (Directive 2004/38/EC) did not apply, the Court moved on to consider the case under Article 20 TFEU and found that Member States could not adopt measures that would 'have the effect of depriving citizens of the Union of the genuine enjoyment of the substance of the rights conferred by virtue of their status as citizens of the Union. ${ }^{105}$ Such deprivation would occur if a Union citizen was obliged to leave the territory of the Union. In the present case refusal to grant Mr Ruis Zamrano, the father of minor Union citizens entirely dependent upon him, a right of residence and a right to work in the home Member State, Belgium. In particular it would oblige them to leave 'the territory of the Union'. 106

\footnotetext{
${ }^{100}$ Ibid Opinion of AG Maduro para 23.

${ }^{101}$ Case C-34/09 Gerardo Ruiz Zambrano v Office national de l'emploi (ONEm) EU:C:2011:124, [2011] ECR I1177.

${ }^{102}$ For an overview of the purely internal rule and its evolution, including in Zambrano see Síofra O'Leary, 'The Past, Present and Future of the Purely Internal Rule in EU Law' in Michael Dougan, Niamh Níc Shuibhne and Eleanor Spaventa (eds), Empowement and Disempowerment of the European Citizen (Hart 2012). For a judicial treatment see in particular the Opinion of AG Sharpston in Zambrano (n 101).

${ }^{103}$ Loic Azoulai, '"Euro-Bonds" The Ruiz Zambrano judgment or the Real Invention of EU Citizenship' (2011) 3 Perspectives on Federalism, 37.

${ }^{104}$ Indeed Hailbronner and Thym have argued that the vision of Union citizenship it entails is radically different from that found in the text of the Treaties. See Kay Hailbronner and Daniel Thym, 'Case Note C-34/09: Zambrano v ONEm' (2011) 48 CMLRev 1253, 1262 ff.

105 Zambrano (n 101) para 42.

106 Ibid para 44.
} 
While much criticised for the brevity and opacity of its reasoning, ${ }^{107}$ Zambrano is clear in providing a new paradigm for understanding Union citizenship. Zambrano is not concerned with the wording of the Treaty or the rights of Union citizenship, but develops an autonomous concept of Union citizenship as a status linking individual holders of that status to the Union legal order. ${ }^{108}$ It is this supranational status and the Zambrano children's membership of the broader European community that brings the issue within the scope of Union law. Note the important symbolic reference not to the territories of the Member States but the 'territory of the Union', described by Azoulai as a normative as well as geographical reference, implying a common space occupied together by Union citizens in accordance with a set of common rights and values, protected by Union law. ${ }^{109}$ Moreover, the reference to the territory of the Union echoes to a large extent the outcome of emphasising the logic of autonomy in the transnational dimension of Union citizenship in creating a single, broader space of movement. In supplementing the rights contained in Article 21 TFEU and Directive 2004/38/EC with a protection based on Article 20 TFEU and the status of Union citizenship, the Court of Justice is in effect supplementing a set of transnational rights with a supranational status, founded in Union law and linking the Union citizen directly with a supranational polity. ${ }^{110}$

\section{An ill-defined and insubstantial substance}

The ruling in Zambrano has been confirmed by the Court of Justice on a number of occasions, as has the new 'genuine enjoyment' test based on the supranational status of Union citizenship. However, in no other case has an applicant been successful in invoking the protection offered by that status or in adding to situations where 'the genuine enjoyment of the substance of the rights' conferred by Union citizenship is at stake. Subsequent cases have significantly limited the scope of what might otherwise have been a relatively openended formula. ${ }^{111}$

\footnotetext{
107 See in particular Niamh Níc Shuibhne, 'Seven Questions for Seven Paragraphs' (2011) 36 EL Rev 161, Hailbronner and Thym (n 104), 1259-1260.

${ }^{108}$ Hailbronner and Thym (n 104), 1263.

109 Azoulai, ""Euro-Bonds" The Ruiz Zambrano judgment or the Real Invention of EU Citizenship' (n 103) 3435.

${ }^{110}$ Hailbronner and Thym (n 104) 1262-1264.

${ }^{111}$ That may in principle have implied a jurisdiction for the Union to intervene to protect a wide range of rights independent of any other link with Union law. For a proposal to use Union citizenship and Zambrano in particular to advance precisely such a federal conception of an EU human rights competence see Armin Von
} 
Firstly the Court has made it clear that individual citizens must be obliged to leave the territory of the Union. If they enjoy rights of residence (that can be enjoyed in practice) under national law, for example by virtue of nationality, they cannot invoke the protection offered by Article 20 TFEU. This applies both if the Union citizen holds the nationality of the Member State of origin ${ }^{112}$ or if he holds the nationality of another Member State to which he can move if necessary. ${ }^{113}$ Moreover, the threshold for this test is high. 'Forced' to leave the territory of the Union means precisely that; the mere desirability of maintaining family life in a particular state is not a sufficient grounds to find that an individual is being 'forced' to leave the territory of the Union if a family member is deported. ${ }^{114}$

Secondly, and related to the above point, whether a Union citizen will be 'forced to leave the territory of the Union' on foot of a decision by a Member State (typically to deport a third country national family member) very much depends on the nature of that relationship of dependence between the Union citizen and the TCN family member. The dependence must be of a strictly material nature. It would seem that emotional or personal dependence is not sufficient, being merely 'desirable'. Furthermore, it is the Union citizen that must be dependent on the third country national family member rather than the reverse. ${ }^{115}$ This dependence does not exist if the Union citizen can be reliant on another family member such as a second parent. ${ }^{116}$

Thirdly, fundamental rights do not appear to be included in the 'substance of the rights' conferred by Union citizenship. While Member State's must have regard to their obligations under the ECHR and under the CFR in situations that fall within the scope of Union law, breach of a fundamental right, such as the right to family and private life, does not in and of itself amount to a denial of the 'genuine enjoyment' of a right conferred by Union citizenship. The result is a clear refusal, at this stage of the Union's development, to create a

Bogdandy and others, 'Reverse Solange - Protecting the Essence of Fundamental Rights against EU Member States' (2012) 49 CML Rev 489.

${ }^{112}$ Even if he also holds nationality of a second Member State. See Case C-434/09 Shirley McCarthy $v$ Secretary of State for the Home Department EU:C:2011:277, [2011] ECR I-3375.

${ }_{113}$ Case C-86/12 Alokpa et al v Minstre du Travail de l'Emploi et de l'Immigration EU:C:2013:645.

${ }^{114}$ Case C-256/11 Murat Dereci and Others v Bundesministerium für Inneres (Dereci) EU:C:2011:734, [2011] ECR I-11315 para 66.

${ }^{115}$ Ibid.

${ }^{116}$ Case C-87/12 Ymeraga v Minstre du Travail, de l'Emploi et de l'Immigration EU:C:2013:291. Leading to the paradoxical situation noted by AG Mengozzi in Derici (n 114) that having a Union citizen parent works to the disadvantage of a Union citizen in terms of family reunification rights under Article 20 TFEU. 
federal type system of fundamental rights protection founded on the status of Union citizenship akin to that constructed on the basis of the Fourteenth Amendment of the United States Constitution. ${ }^{117}$ In other words membership of the supranational community of the Union is not in and of itself sufficient grounds to invoke the protection of fundamental rights offered by the Union. We have not yet reached the stage where an individual is entitled to say "ccivis europeus sum" and to invoke that status in order to oppose any violation of his fundamental rights. 118

The result is a clear and dramatic narrowing of the application of any test under Article 20 TFEU. The exceptional nature of such an application has been highlighted by Court, noting in both Alopka and Ymeraga that it applies only in 'very specific situations'. ${ }^{119}$ In these two cases the language and justification of the Court has also shifted somewhat, claiming that the rights derived from Article 20 TFEU have an intrinsic connection with the freedom of movement of a Union citizen' ${ }^{120}$ and has employed the language of 'effectiveness' when describing the test under Article 20 TFEU. While the concept of effectiveness has been used to promote the application of EU law in other areas, ${ }^{121}$ it does tend to characterise Article 20 TFEU in instrumental terms rather than the inherent protection of the individual as a European conferred by the 'fundamental status' of Union citizenship.

The result of McCarthy, Derici, Iida, Ymeraga and Alopka is that while it is clear what the 'genuine enjoyment of the substance of rights' conferred by Union citizenship is not, what is less clear is what it in fact is. ${ }^{122}$ In particular it is not clear under what circumstances Article

\footnotetext{
117 See the reference in the Opinion of AG Sharpston in Zambrano (n 101) para 172. For a history of the adoption of the XIVth Amendment and the subsequent 'incorporation doctrine' expressly applying parts of the federal Bill of Rights to the actions of States see Michael Kent Curtis, No State Shall Abridge: The Fourteenth Amendment and the Bill of Rights (Duke UP 1987). Interestingly, the justification for this advanced by AG Mengozzi is based not in a textual reading of the citizenship provisions but rather in the overall inter-locking system of fundamental rights protection in Europe consisting of national, Union and international levels of protection and the need to respect the respective roles of these different jurisdictions. See Derici (n 114) Opinion of AG Mengozzi, para 39.

118 Case C-168/91 Christos Konstantinidis v Stadt Altensteig - Standesamt and Landratsamt Calw Ordnungsamt EU:C:1993:115, [1991] ECR I-1191 Opinion of AG Jacobs para 46.

${ }^{119}$ Alokpa (n 112) para 32 and Ymeraga (n 116), para 36.

${ }^{120}$ Ymeraga (n 116), para 37.

121 See the overview offered by Herlin Karnell in Ester Herlin-Karnell, The Constitutional Dimension of European Criminal Law (Hart 2012) ch 4.

${ }^{122}$ While there is no jurisprudence by the Court of Justice as of yet, at least one national court has also excluded welfare benefits from the scope of the 'genuine enjoyment' test. See Iyiola Solanke, 'HC and Sanneh - 'genuine enjoyment' does not include social welfare' (eutopia law, 20 December 2013) $<$ http://eutopialaw.com/2013/12/20/hc-and-sanneh-genuine-enjoyment-does-not-include-social-welfare/\#more2216> accessed 28 January 2014.
} 
20 TFEU and the supranational status of Union citizenship will apply, beyond the very denial of such a status either in law, as in Rottmann or in fact, as in Zambrano. The result is the perhaps intermediary situation where the existence of a supranational dimension to Union citizenship is beyond doubt. Rottmann and Zambrano are based on the understanding of Union citizenship as an autonomous status, operating independently of other considerations of Union law (in particular cross-border movement) that can be invoked against a Member State of origin where the very existence, or substance of that status is threatened. Union citizenship therefore reflects the existence of a civic community between Europeans located at a supranational level. However, beyond its bare existence the precise content of this status, in terms of rights and obligations, and the characteristics of this community, in terms of values or principles, remain unclear. In a series of judgments the Court while confirming the essence of the status, has shied away from any moves to put 'flesh on the bones' of supranational citizenship, to paraphrase O'Leary. ${ }^{123}$

In the area of criminal law, this direct link between the Union and individual Union citizens is similarly poorly developed. As is explored further in Chapter 7 the Union's competence to criminalise behaviour and directly impose obligations on individuals is limited and moreover is necessarily mediated by national law. The Union similarly lacks a capacity to call individuals to account communicate the moral judgment of the community, so central to Duff's community-based account of criminal law, to individuals. There would not appear to be a particularly well-defined community at a supranational level and expressed through supranational institutions and legislation to which individuals are 'called to account' for their wrongful conduct. There does appear to be a certain capacity of the Union to articulate certain supranational public wrongs but the most immediate function of this is not to directly articulate a normative community at a supranational but rather to frame and facilitate transnational processes.

\section{Conclusion}

This chapter is an attempt to disaggregate the various dimensions of Union citizenship in order to facilitate further enquiry into the interaction between Union citizenship and criminal law. It does not exclude other perspectives on Union citizenship, particularly those

\footnotetext{
${ }^{123}$ O'Leary, 'Putting flesh on the bones of European Union Citizenship' (n 62).
} 
concentrating on the political nature of Union citizenship and its practice in a more participative fashion, ${ }^{124}$ or its broader constitutional significance for the Union as a whole. ${ }^{125}$ It divides Union citizenship into elements; social integration, autonomy and a supranational community, to provide headings in order to better investigate the interaction of Union citizenship and criminal law. These elements interact and combine in different ways; any isolated consideration is likely to be somewhat artificial and to miss an important point regarding the whole that is more than these component parts. In particular social integration and autonomy together offer individual Union citizens a broader space of movement; the Union territory as composed of Member States that in turn is linked to the supranational status of citizenship and in particular the right to the Union territory as echoed in the Zambrano line of caselaw. There is therefore an interaction between the transnational and the supranational, in which certain supranational phenomenon emerge from transnational processes and transnational processes are framed, justified and facilitated by supranational phenomena. This interaction between the transnational and the supranational is echoed throughout the rest of this thesis.

\footnotetext{
${ }^{124}$ See ex Antje Weiner, European Citizenship Practice (Westview Press 1998).

${ }^{125}$ See ex Dmitry Kochenov, 'The Citizenship Paradigm' (2012-2013) 15 CYELS 197.
} 


\title{
Social Integration and Crime
}

\section{Inclusion and Exclusion - Transnational and Supranational}

\author{
The Social Integration Paradigm
}

EU citizenship is principally, if not exclusively, a status of social integration. ${ }^{1}$ In practice this transnational status enables EU citizens to move to and become part of another society in the European Union. It is a right to acquire rights in another Member State and to gain a status that approaches (if never quite equals) national citizenship. The borders of national communities are not eliminated but become more porous, open to other nationals of European Union Member States. ${ }^{2}$

Acquiring these rights is not however automatic and instantaneous but involves an on-going process. The main principal developed by the Court of Justice ${ }^{3}$ and taken up by the legislature $^{4}$ is that of social integration. The relationship between rights and integration is seen as a continuously mutually reinforcing process: rights and the protections offered by rights are seen as a means of enabling the integration of the EU citizen. Further integration in turn leads to more secure rights to residence and equal treatment in particular. The result is a framework for the development of the relationship between the host Member State and the individual, a relationship that develops along an axis of social integration. Focusing on the transnational dimension, the concept of social integration establishes a framework for a relationship between the host society and the individual migrant Union citizen. However, it is a relationship that is curiously lopsided, with most duties, including duties of equal treatment and financial and social solidarity flowing from the Member State. Beyond certain

\footnotetext{
${ }^{1}$ See Loic Azoulai, 'La citoyenneté européenne, un statut d'intégration sociale' in Gérard Cohen-Jonathan and others (eds), Chemins d'Europe: Mélanges en l'honneur de Jean Paul Jacqué (Dalloz 2010). And Anastasia Iliopoulou Penot, 'The Transnational Character of Union Citizenship' in Michael Dougan, Niamh Níc Shuibhne and Eleanor Spaventa (eds), The Empowerment and Disempowerment of the European Citizen (Hart 2012).

${ }^{2}$ See Dora Kostakopoulou, 'European Citizenship: Writing the Future' (2007) 13 ELJ 623.

${ }^{3}$ Case C-209/03 The Queen (on the application of Dany Bidar) v London Borough v Ealing, Sec. of State for Education and Skills EU:C:2005:169, [2005] ECR I-2119.

${ }^{4}$ Directive 2004/38/EC on the right of citizens of the Union and their family members to move and reside freely within the territory of the Member States (Citizenship Directive) [2004] OJ L 158/77 (Citizenship Directive).
} 
economic 'conditions' attached to residence, ${ }^{5}$ there appears to be little in the way of explicit requirements on the part of the individual.

\section{The Relationship with the Host Society - Inclusion and Exclusion}

Developed principally in the field equal treatment for social benefits, the principle of social integration has been extended to regulate the status of migrant Union citizens in other areas, ${ }^{6}$ including in the area of criminal law. Four areas in particular have developed: Article 4(6) of the European Arrest Warrant Framework Directive (EAW FD) ${ }^{7}$ on the right to remain in a state to serve a sentence; the Transfer of Custodial Sentences Framework Decision; expulsion decisions under Article 28 of the Directive 2004/38/EC (Citizenship Directive) ${ }^{8}$ and the question of imprisonment and the calculation of periods of residence under the same Directive.

In all four areas dealing with the rights of criminal migrant Union citizens and in particular their relationship with the host Member State is regulated by the concept of social integration. It is a clear extension of the principle from the area of social solidarity and equal treatment to welfare rights to a different area, indicating that the concept of social integration is set to become the key operative principle in regulating the relationship of the Union citizen to the host Member State. However, social integration, once extended to such diverse fields necessarily engages different concerns that in turn can alter the nature of the social integration paradigm and feedback into our understanding of Union citizenship. This is precisely what has occurred in the field of criminal law with two issues, particular to the criminal justice system, being incorporated into the social integration test.

Chapter 3 details the caselaw relating to Article 4(6) EAW FD and the Transfer of Sentences Framework Decision. These two instruments and the Court's case law have focused on the need to rehabilitate the offender as a widely accepted goal of the criminal justice system. This has been incorporated into the social integration test as reinforcing the 'right' of the migrant Union citizen, who is sufficiently integrated, to remain in the host Member State in

\footnotetext{
${ }^{5}$ See Case C-325/09 Secretary of State for the Home Department v Maria Dias EU:C:2011:498, [2011] ECR I6387.

${ }^{6}$ See Case C-524/06 Heinz Huber v Bundesrepublik Deutschland EU:C:2008:724, [2008] ECR I-9705.

${ }^{7}$ Framework Decision 2002/584/JHA on the European arrest warrant and the surrender procedures between Member States (EAW FD) [2002] OJ L 190/1.

${ }^{8}$ Citizenship Directive (n 4).
} 
order to serve his sentence. ${ }^{9}$ Rehabilitation concerns the reintegration of the individual into society, a reintegration that is said to be facilitated by remaining close to family and a social network and being in a familiar environment. Thus while operating within the very different field of penology and criminal justice, the concept of rehabilitation dovetails with the EU law concept of social integration and reinforces the inclusion of the Union citizen in the society of the host Member State. The obligations of the host Member State are therefore extended or reinforced through the use of the concept of rehabilitation. In terms of its operation this is a relatively straightforward application of the principle of social integration: the greater the degree of social integration, the greater the rights of the migrant citizen and the greater his legal inclusion and level of protection. The only difference is that rehabilitation reinforces the traditional operation of the principle of social integration.

Starkly different in effect is the conception of criminal law employed in the second two areas, the expulsion cases and the cases dealing with periods of imprisonment dealt with in Chapter 4. In these cases a view of the criminal law as wrong-doing emerges. Moreover it is wrong-doing against society as a whole, the values and norms of which are reflected in the criminal law. Unlike rehabilitation which is complementary, crime as wrong-doing is inimical to the process of social integration and implicitly justifies the expulsion of the criminal Union citizen. Residence rights, be they permanent residence or enhanced protection against expulsion, are the result of a process of social integration. Criminal acts that result in imprisonment rupture that process of integration resulting in a loss or a failure to acquire rights relating to Union citizenship. This concept of crime has therefore has resulted in a degree of exclusion for the offending Union citizen.

\section{Between Transnational and Supranational}

The use of criminal law concepts in these series of cases and legislation analysed in these two chapters has tended to alter the relationship between the individual and the host society, leading to both greater inclusion and exclusion. What is similar to both however is that it is the national community that remains the social unit and it is the relationship between the migrant Union citizen and the national community that is at stake. These are primarily transnational processes. However, in both rehabilitation and crime as wrong-doing, their

\footnotetext{
${ }^{9}$ If the Member State has in fact decided to implement the optional provision.
} 
inclusion in the social integration paradigm appears to give rise to certain supranational elements. In cases dealing with the rehabilitation of offenders, there does appear to be a Union-wide interest in their reintegration into society, an interest and responsibility that is shared amongst Member States depending on the criteria of nationality on the one hand and social integration on the other. More clear is the supranational element contained in the case of crime as wrong-doing and its interaction with national and transnational processes. Here, while on its face the duty in question may appear negative and national it in fact reveals positive and supranational dimensions. On the one hand there appears to be a clear implication that the individual migrant citizen should adopt a particular attitude of respect towards the host society. On the other hand, while the content of the duty arises from national criminal law, in its nature and consequences it is in fact supranational. It is a duty imposed by Union law and entails the loss of rights of Union citizenship, in addition to whatever consequences may flow from national law. This appears to be confirmed by a certain validation by which national values justifying expulsion are endorsed by Union instruments. What appears to emerge is a duty of respect towards the values of the host society peculiar to Union citizenship reflecting both a re-balancing of the relationship of integration between the host-society and the individual - placing more emphasis on the role of the individual - and also a shift in the quality of that integration from an economic to a normative or indeed moral plane. 


\section{Chapter 3}

\section{Social Integration I}

\section{Rehabilitation and Inclusion}

\section{Introduction: \\ Rehabilitation and Social Integration}

From the external perspective citizenship, and or rather its international law corollary, nationality, was developed as a means of allocating individuals to particular political units or states. ${ }^{1}$ International law aims at a complete and discrete system whereby all individuals are allocated to a state, and only one state. ${ }^{2}$ At this stage of the development of Union citizenship it is evident that within the European Union an additional criteria is used to establish a bond and a defining link between an individual and a particular state, that of social integration. Social integration is usually thought of in terms of rights, the rights of the individual. But rights correlate with duties or responsibilities ${ }^{3}$ and from the point of view of Member States the concept of social integration is a supplementary means of allocating responsibility between different states for particular individuals. Union citizens from other Member States who are sufficiently integrated into the host society are entitled to a certain degree of solidarity. Similarly, in the converse situation, so long as a degree of social integration persists, Member States are obliged to continue to extend certain, nonterritorially linked, benefits to their own nationals who seek to travel to another Member

\footnotetext{
${ }^{1}$ Rogers Brubaker, Citizenship and Nationhood in France and Germany (Harvard UP 1992) 3 ff. See also Alison Kesby, The Right to have Rights: Citizenship, Humanity and International Law. (OUP 2012) ch 2.

${ }^{2}$ Rainer Bauböck, Transnational Citizenship: Migration and Rights in International Migration (Edward Elgar 1994) 24. In both respect it fails; there are still both de facto and de jure stateless individuals in the world today (see Kesby (n 1) ch 1). At the same time within increasing migration there is an ever increasing number of individuals with dual or multiple nationality and ever increasing number of states that permit such a situation.

${ }^{3}$ It should be noted that the correlativity theory is contested in rights theory. See HLA Hart, "Are there any Natural Rights?' (1955) 64 The Philosophical Review 175, 177 ff.
} 
State. $^{4}$ In short, the obligations and responsibilities that Member States hold towards individuals waxes and wanes with their degree of social integration.

In the context of criminal law the concept of social integration plays a different role. From a traditional sociological perspective, first presented by Durkheim and echoed by legal moralists such as Lord Devlin, the purpose of the criminal law was to express a certain form of social solidarity. ${ }^{5}$ Breach of the criminal law emerged from a state of anomie or normlessness, in which certain section of society individuals found themselves. ${ }^{6}$ Put bluntly, the criminal law, and in particular punishment, was society striking back at an action that damaged the normative bonds of society, thereby reasserting its values and coherence. ${ }^{7} \mathrm{~A}$ related concept of social (re)integration exists in the area of penology as one (and at times the principal) purpose of punishment. Starting from the same premise that criminal activity is a symptom of a social alienation on the part of the individual and a lack of integration in the social, economic and perhaps cultural structures of society, the goal of the treatment of offenders should therefore be to 'reintegrate' the individual into society - to rehabilitate him, to render him a 'functioning', law-abiding, member of society. ${ }^{8}$

The two meanings of the concept - in EU law as the means of determining the rights and responsibilities of individuals vis-à-vis particular states and in criminal law as a symptom of social alienation and rehabilitation as a goal of the penal process- have been integrated by the Court of Justice and by the Union legislature in a series of cases and legislation dealing with where an individual may serve his or her sentence. The result of importing the logic of rehabilitation within the social integration framework of Union citizenship has been the reinforcement of the inclusion of the migrant Union in the society of the host Member State. It has altered the traditional concepts of allocating responsibility for criminal (troublesome) Union citizens, expanding and altering the concept of the national community for these

\footnotetext{
${ }^{4}$ See for example Case C-503/09 Lucy Stewart v Secretary of State for Work and Pensions EU:C:2011:500, [2011] ECR I-6497or Joined Cases C-11/06 and C-12/06 Rhiannon Morgan v Bezirksregierung Köln and Iris Bucher v Landrat des Kreises Düren EU:C:2007:626, [2007] ECR I-9161. See further ch 2.

${ }^{5}$ Emile Durkheim, The Division of Labour in Society (George Simpson tr, Collins-MacMillian 1933) ch 2.

${ }^{6}$ HLA Hart, Law, Liberty and Morality (OUP 1962) 48. See also Paul Rock, 'Sociological Theories of Crime' in Robert Reiner, Mike Maguire and Rod Morgan (eds), The Oxford Handbook of Criminology (5 edn, OUP 2012) 44-49.

${ }^{7}$ Durkheim (n 5) ch 2.

${ }^{8}$ There have been different understandings advanced for rehabilitation from correctional, to social integration properly speaking to a legal form of restoring the individual to a status of citizenship. For a typology of the forms and justification of different understandings of rehabilitation see Peter Raynor and Gwen Robinson, Rehabilitation, Crime and Justice (Jo Campling ed, 1 edn, Palgrave Macmillan 2005) chs 1-2.
} 
purposes, while at the same time raising the possibility of a pan-European interest in the rehabilitation of the offender and a collective responsibility for communicating the wrongfulness of the conduct. Two areas - the 'nationality exception' in the European Arrest Warrant Framework Decision (EAW FD) and the Framework Decision on the Transfer of Sentences - highlight this change.

\section{The Transformation of the Nationality Exception}

A staple of extradition law is the so-called nationality exemption. ${ }^{9}$ Under this rule, common in continental legal systems but less so in the common law tradition, individuals who hold the nationality of the particular state are shielded from unconsented extradition to another state for the purposes of placing them on trial or for serving a sentence. The rationale for the exemption has been linked to a mistrust of other criminal justice systems and the particular bond established between the sovereign and its subjects reflected in the status of nationality. ${ }^{10}$

In an effort to secure a more effective system of transfer and a single area of justice, ${ }^{11}$ the European Arrest Warrant sought to eliminate this 'exception' in extradition law. While an abolition was proposed by the Commission with its replacement by a principle on integration, ${ }^{12}$ the final text contained a modified 'nationality exemption' in Articles 4(6) and 5(3) of the European Arrest Warrant Framework Decision. ${ }^{13}$ Article 4(6) EAW FD is an optional provision, allowing Member States to refuse to surrender their nationals or persons 'resident or staying in' that Member State for the purposes of serving a sentence if they undertake to allow the individual to serve the sentence in that Member State. Similarly, Article 5(3) EAW FD allows Member States to impose a guarantee on the surrender of nationals or residents in cases concerning individuals standing for trial, such that the individual concerned will be able to return to the executing Member State to serve his or her sentence in the event that a custodial sentence is imposed. Thus individuals could serve their sentence in a particular Member State with which they had 'special bonds', including

\footnotetext{
${ }^{9}$ See Michael Plachta, '(Non-)Extradition of Nationals: A Neverending Story’ (1999) 13 Emory Int'l L Rev 70.

${ }^{10}$ Ibid.

${ }^{11}$ See further chapter 5 .

12 Proposal for a Council Framework Decision on the European arrest warrant and the surrender procedures between the Member States COM(2001) 522 final [2001] OJ C 332 E/18, art 33.

${ }^{13}$ Framework Decision 2002/584/JHA on the European arrest warrant and the surrender procedures between Member States (EAW FD) [2002] OJ L 190/1 (EAW Framework Decision).
} 
nationality, while at the same time remaining subject to the criminal law of other Member States.

It will be noted that unlike the nationality exemption as traditionally applied, Articles 4(6) and 5(3) EAW FD are designed to ensure that the individual concerned does in fact face trial and/or serve her sentence; she is not entitled to escape justice. Moreover, she must face trial before the courts of the issuing Member State. ${ }^{14}$ Articles 4(6) and 5(3) EAW FD only ensure that she can serve her sentence closer to home and in particular in her 'home' Member State. The consequences of this abolition of the nationality exemption and the obligation to serve a sentence imposed by another Member State on the relationship between the nationals of a particular Member State and other Member States in the construction of a single area of justice is analysed in further detail in chapter 5. This chapter is concerned with the separate matter of the relationship between Union citizens who are not nationals of the executing Member State and the extent to which the Court in particular has used the concept of social integration to reinforce their inclusion in the host society.

While billed as the replacement to the 'nationality exemption' the rules contained in Articles 4(6) and 5(3) EAW FD, as they have been interpreted by the Court of Justice, are of a fundamentally different nature. Beyond ensuring that the individual concerned does have to stand trial and suffer punishment, two differences in particular stand out - the subject of the exception and the justification for the exception. The exception is now to be applied not just to nationals but to residents and, in the case of Article 4(6) EAW FD, also those 'staying in' a Member State. Similarly, in its interpretation of those particular terms the Court of Justice has justified the exception not on some essential and traditional bond between an individual and his sovereign but rather on the more modern, and more flexible, concept of rehabilitation. Both changes have been driven by an interpretation based on Union citizenship.

\section{Subject of the Exception; from nationals to Union citizens}

The EAW FD itself clearly indicates that the new 'exception' is to apply to both nationals and other individuals sufficiently connected with or integrated into the host society. In

\footnotetext{
${ }^{14}$ Under extradition treaties states sometimes would undertake to surrender or prosecute. See Plachta (n 9). The difference with the EAW system is that it is the issuing member State who prosecutes and tries the individual.
} 
addition to nationals, Article 4(6) EAW FD applies to persons staying in or resident in the host society, whereas Article 5(3) EAW FD applies to residents.

In interpreting these terms the Court has drawn explicitly on Union citizenship, and in particular that part termed in chapter 2 the social integration dimension, in order to determine the precise contours of these new groups of persons who can benefit from Articles 4(6) and 5(3). In Kozłowski, in interpreting the notion of 'staying in', the Court defined the category in terms of 'connections' with the host society and in particular an 'overall assessment of various objective factors characterising the situation of that person which include...the length, nature and conditions of his presence and the family and economic connections which he has with the executing Member State. ${ }^{15}$

Whereas in Kozłowski the link with Union citizenship was implicit, in Wolzenburg, it is rendered explicit. The Dutch provision in question, requiring a five year period of residence and a formal residence permit before non-nationals could benefit from the exemption, was deemed to be discriminatory and contrary to Article 20 TFEU, in the light of the provisions of Union citizenship and Article 18 TFEU in particular. ${ }^{16}$ When justifying such discrimination the Member State was entitled to raise the prospect of reserving the exception for individuals with a sufficiently close links to the host society, to be assessed according to the criteria of social integration and in light of the principle of proportionality. ${ }^{17}$

Finally, in da Silva, the obligations on the Member States to expand the group of persons who may benefit from Article 4(6) EAW FD (and presumably by implication Article 5(3) EAW FD) was brought full circle. If Member States opt to implement Article 4(6) in relation to their own nationals, they cannot automatically and categorically exclude nationals of other Member States. ${ }^{18}$ In its rejection of the French government's argument that international obligations only allowed it to refuse surrender for its own nationals, the Court, relying on the

\footnotetext{
${ }^{15}$ Case C-66/08 Proceedings concerning the execution of a European arrest warrant issued against Szymon Kozlowski EU:C:2008:437, [2008] ECR I - 6041para 48.

${ }^{16}$ As pointed out by Herlin-Karnell the application of the citizenship provisions, and in particular the prohibition on non-discrimination, is both unsurprising and to be welcomed and may very well be applicable to other aspects of the Framework Decision that may have been implemented in a discriminatory manner. See for example the Swedish provision applying the statute barred ground for refusal to Swedish nationals only. Ester Herlin-Karnell, 'The Swedish Supreme Court and the European Arrest Warrant: Comment on the decision of 21 March 2007, surrending of Polish National (Ö 430-07)’ [2007] Europarättsligtidskrift 885.

${ }^{17}$ Case C-123/08 Dominic Wolzenburg EU:C:2009:616, [2009] ECR I-9621 para 67.

${ }^{18}$ Case C-42/11 Proceedings concerning the execution of a European arrest warrant issued against João Pedro Lopes Da Silva Jorge EU:C:2012:517 para 50.
} 
Commission's submissions, points out that for the purposes of those obligations, a state may define the term 'national' to include those resident in that state, an option that has been exercised by a number of states. ${ }^{19}$ In effect, the Court implied that a Member State may be required under Union law and more particularly the duty of conform interpretation in combination with Union citizenship, to define, under certain international instruments, as its own nationals Union citizens that are sufficiently integrated.

Both the legislation and the Court allowed Member States to retain the category of nationality when operating Article 4(6) and 5(3) EAW. In Wolzenburg, the Court highlighted the ability of Member States to privilege their own nationals in matters of surrender, finding that the Dutch provision automatically preventing the surrender of Netherlands nationals 'does not appear excessive' in light of their presumed strong connections to Dutch society. ${ }^{20}$ AG Bot, who was of the opinion that one of the main goals of the Framework Decision was to abolish the nationality exemption, proposed a reading of Article 4(6) EAW FD that would require Member States to assess on a case-by-case basis an individual's chances of rehabilitation in the executing state. ${ }^{21}$ The Court of Justice implicitly rejected that view by allowing Member States to maintain a blanket ban by asserting the perhaps overly simplistic view that nationals will necessarily be able to reintegrate in their 'own' Member State. ${ }^{22}$ Thus under the EAW FD Member States are permitted to retain the nation and nationality as a framework for the community but this is complemented by those with sufficient social connections to the host Member State. Thus, while ensuring that nationality remains a relevant criterion in the operation of the provisions, it has reinterpreted it in light of social links and connections rather than through some pre-social, ethno-cultural notion of belonging or some idealized link between the sovereign and its subjects. Nationals are presumed to have sufficiently strong connections with the society of the host society that justifies the automatic application of Article 4(6) EAW FD. Nationality here is not some form of traditional, quasi-mystical ethno-cultural bond but rather a proxy (albeit perhaps in some cases a rather tenuous one) for the social connections an individual enjoys with a particular Member State.

\footnotetext{
${ }^{19}$ Ibid paras 47-48.

${ }^{20}$ Wolzenburg (n 17) para 70.

${ }^{21}$ Ibid paras $126 \mathrm{ff}$.

22 'the view may reasonably be taken that the rule that a European arrest warrant may not be executed against nationals of the Member State of execution does not appear to be excessive. Those nationals have a connection with their Member State of origin such as to ensure their social reintegration after the sentence imposed on them has been enforced.' ibid para 70 .
} 


\section{Justification: From nationality to rehabilitation}

The reason why social connections were deemed relevant for the operation of the exemption is linked to the criminological understanding of social integration identified above. It is not the affective tie to the sovereign or distrust of other legal systems that justifies Articles 4(6) and 5(3) EAW FD but the more prosaic concept of rehabilitation and social reintegration. The Court first identified rehabilitation and reintegration as one of the goals of the EAW FD in Kozlowski. Article 4(6) EAW FD has 'the objective of enabling the executing judicial authority to give particular weight to the possibility of increasing the requested person's chances of reintegrating into society when the sentence imposed on him expires. ${ }^{23}$ This goal of the Framework Decision is also raised in Wolzenburg (albeit in tension with the other goal of the Framework Decision to create an effective system of surrender) ${ }^{24}$ and fused with the concept of social integration that regulates the equal treatment of migrant Union citizens.

The use of the Union citizenship concept of social integration and the concept of rehabilitation are complementary. It is precisely because Article 4(6) EAW FD seeks to promote reintegration and rehabilitation that it is particularly appropriate to use the language and the test of social integration in assessing which individuals may benefit from the provision. Those Union citizens that are sufficiently integrated are entitled to equal treatment, including in their chances of rehabilitation in their now 'home' society. Moreover, their chances of rehabilitation are greater in that society because they are deemed to be integrated. The combined logic of equal treatment, Union citizenship, social integration and rehabilitation, therefore serves to reinforce the inclusion (of sufficiently integrated) Union citizens in the host society.

The result of these three cases and the interpretation of Article 4(6) of the EAW Framework Decision is striking. Rather than renounce the continued importance of national communities and nationality and abolish altogether the possibility of employing the nationality exemption, the Court has allowed Member States remarkable discretion in retaining automatic refusals

\footnotetext{
${ }^{23}$ Kozłowski (n 15) para 45.

${ }^{24}$ See criticism by Peers in Steve Peers, 'The European Arrest Warrant: The Dilemas of Mutual Recognition, Human Rights and EU Citizenship' in Allan Rosas, Yves Bot and Egils Leits (eds), The Court of Justice and the Construction of Europe: Analyses and Perspectives on Sixty Years of Case-Law (Asser Press 2013).
} 
to surrender their own nationals. ${ }^{25}$ However, it is not true that following Wolzenburg, and even more so da Silva 'European citizenship is not yet the basic paradigm for the condition of the individual confronted with a Member State's public power within the EU's AFSJ. ${ }^{26}$ Such a view ignores the progressive nature of Union citizenship based on social integration, one that is strengthened and deepened over time as a greater degree of integration is reached. What these cases have underlined is the importance that Member States, when operating their 'nationality exception', leave open the possibility that other Union citizens, those sufficiently integrated, may benefit from it, in effect rendering the borders of national communities for the purposes of determining the responsibility placed on a state with respect of enforcing sentences more porous and open to nationals of other Member States. While one may agree or disagree with the discretion afforded Member States in applying this rule, in particular the application of a blanket five year residence requirement, it does fit with the concept of Union citizenship as a status that is strengthened as a result of social integration. ${ }^{27}$ Furthermore, nor is it without interest that this has been achieved by placing the 'nationality' exemption in a more social setting, stressing the importance of social ties to the community and softening the otherwise exclusionary nature of a more traditional ethno-cultural view of the national community. While retaining the importance of the national community, Article 4(6) has rendered it less exclusionary and based more on the societal and legal realities inherent in Union citizenship. It has done this by employing the concept of genuine links to the host society and social integration familiar in other areas of Union citizenship law and reinforcing it with the principle of rehabilitation.

Complementing rather than replacing the logic based on a special political bond between national and state with a social bond based on integration and the responsibility of rehabilitation appears to be confirmed by the legislative history of the Framework Decision. In its original proposal the Commission emphasised the importance attached to the principle of integration in the application of the European Arrest Warrant system. Recital 13 of the proposal emphasises that due consideration should be given for the reintegration of criminals

\footnotetext{
${ }^{25}$ Contrary to the opinions of Advocate Generals Bot and Mengozzi in Wolzenburg (n 17) and da Silva Jorge (n 18) respectively who both argued that such a system runs contrary to the wording of Article 4(6) and the spirit of the Framework Decision that aims at the removal of barriers to surrender.

${ }^{26}$ Luisa Marin, 'A Spectre is Haunting Europe': European Citizenship in the Area of Freedom, Security and Justice' (2011) 17 EPL 705, 726.

${ }^{27}$ Perhaps allowing the operation which, by any standards, is a form of direct discrimination on the grounds of nationality that is not justified by one of the explicit exceptions would be problematic for internal market purists.
} 
and that fact should be reflected in the place in which they serve their sentence. ${ }^{28}$ Furthermore under Article 33 of the proposal, entitled 'The Principle of Integration', the Commission proposed an optional ground of refusal, refusing surrender and imposing the sentence in the executing state, to take into account the possible 'better possibilities of integration' in the executing state. ${ }^{29}$ A comparison with the final version reveals the replacement of this article on the 'Principle of Integration' with more traditional provisions, retaining the category of national but extending it to other persons, namely those 'staying in' or 'resident' deemed to have a particular relationship with the executing state. The express inclusion of nationality as a ground for refusal, while extending it to other sufficiently connected individuals does not imply a rejection of the principle of integration. Indeed, the Court has subsequently upheld its view in a number of other cases, not directly related to Article 4(6) that the Framework Decision is informed by the concept of social rehabilitation. ${ }^{30}$ However, it has accommodated the concept of nationality within the principle of social rehabilitation by implicitly accepting that nationals enjoy a particular relationship to their 'home society' that facilitates reintegration. This pattern is repeated in another complementary piece of legislation, namely the Framework Decision on the Transfer of Sentences, to which we now turn.

\section{The Framework Decision on the Transfer of Sentences}

Articles 4(6) and 5(3) of the EAW FD have been complemented by a Framework Decision on the Transfer of Sentences that applies the principle reflected in those articles: that individuals should serve their sentence in the state with which they enjoy the closest connection and in particular that in which they would enjoy the best chances of reintegration. As with Articles 4(6) and 5(3) the principle of nationality is supplemented by taking into account those with a particular connection to a particular society.

The guiding principle of the Framework Decision on the Transfer of Sentences is that of social rehabilitation and reintegration. ${ }^{31}$ Accordingly, the core of the Framework Decision is

\footnotetext{
${ }^{28}$ EAW Commission Proposal (n 12) recital 13.

${ }^{29}$ Ibid art 33(1).

${ }^{30}$ See Case C-306/09 IB EU:C:2010:626, [2010] ECR I-10341 para 32 and Case C-192/12 PPU Melvin West EU:C:2012:404 View of AG Cruz-Villalón para 73.

${ }^{31}$ Framework Decision 2008/909/JHA on the application of the principle of mutual recognition to judgements in criminal matters imposing custodial sentences or measures involving deprivation of liberty for the purposes of
} 
contained in Article 4 that outlines those circumstances under which a Member State must, or is encouraged to, execute a custodial sentence. As with Article 4(6) and 5(3) EAW FD an assessment of a sentenced person's chances of rehabilitation is to be made taking into account his integration in the executing state and as with Articles 4(6) and 5(3) the relevant criteria for determining this are nationality on the one hand, and residence with sufficient social connections on the other.

Under the Framework Decision on the Transfer of Sentences a Member State (the issuing Member State), where it considers a person's rehabilitation would be best served by a transfer, may forward a judgement to a second Member State (the executing Member State) where, after consultation with the executing Member State and the individual concerned, it is thought rehabilitation would best be served. In principle, decisions to transfer the sentence are automatically recognised and the executing Member State shall take the necessary measures to enforce it, ${ }^{32}$ in accordance with its own laws. ${ }^{33}$ The usual grounds for nonrecognition of judgements apply, including cases involving minors, statute barred cases, ne bis in idem ${ }^{34}$ and residual cases of dual criminality. ${ }^{35}$

As with the Court's interpretation of the relevant provisions of the EAW FD, responsibility for sentenced persons is allocated based on a mixture of nationality and the social connections a person might have with a particular society. Sentenced persons are divided into three categories for the purposes of the Framework Decision: nationals of the executing state who live in that state; nationals of the executing state who will be deported to that state upon release and, finally, other individuals. Member States are obliged to accept persons who fall into the first two categories, i.e. nationals who either live in the executing state or will be deported there upon release. Furthermore, the consent of the sentenced person is not required in these cases. The consent of the executing Member State and the sentenced person is required for the final, residual, category. However, it does not appear that Member States may categorically refuse to accept the transfer of persons falling within the final category. Member States are instead obliged to adopt legislation outlining the criteria to be used when deciding whether to accept individuals under the final, residual, category taking into account

their enforcement in the European Union [2008] OJ L 327/27 (Framework Decision on the Transfer of Custodial Sentences), recital 9.

${ }^{32}$ Ibid art 8(1).

${ }^{33}$ Ibid art 17.

${ }^{34}$ Ibid art 9.

${ }^{35}$ Ibid art 7(3). 
the goal of social rehabilitation. ${ }^{36}$ Furthermore, they are encouraged, through reciprocal notification, to automatically accept all nationals not covered by the first two categories and residents of five years or more who will retain that right of residence upon release. ${ }^{37}$

In relation to Union citizens, it is arguable that the principle of non-discrimination would apply to the Framework Decision on the Transfer of Sentences in a similar fashion as in the case of Article 4(6) of the EAW FD. Following the logic of Wolzenburg and da Silva, Member States could legitimately privilege their own nationals, who can be assumed under those cases to already have the requisite social connections with the 'home state'. However, they would not be entitled to exclude automatically and categorically all non-national Union citizens from the application of the Framework Decision. Rather, they would be obliged to adopt legislation to enable the relevant authorities 'to assess whether there is a legitimate interest which would justify the sentence imposed in the issuing Member State being enforced within the territory of the executing Member State. ${ }^{38}$

Aside from the usual ground of effectiveness that drives much of the EU criminal law agenda, one of the main motivations for adopting the Framework Decision was that the international law instruments it replaced only allowed the transfer of nationals. ${ }^{39}$ The Framework Decision therefore establishes a scheme, guided by the principle of social rehabilitation, allocating responsibility to particular Member States for particular individuals. In doing so it extends this responsibility beyond the traditional criteria of nationality to include non-nationals deemed to have a particular relationship with that state. This relationship is be determined by the person's social ties to the host society and may be assumed in the case of long-term or permanent residents. In making decisions under the Framework Decision states should take into account 'the person's attachment to the executing State, whether he or she considers it the place of family, linguistic, cultural or economic and other links to the executing state. ${ }^{40}$ This connection is also deemed to be established through secure residence. Member States may exercise an option to automatically accept permanent residents. If they do so it is envisaged that 'permanent residence' for the purposes of the Framework Decision refers to residence on the basis of

\footnotetext{
${ }^{36}$ Ibid art 4(6).

${ }^{37}$ Ibid art 4(6).

${ }^{38}$ da Silva Jorge (n 18) para 51.

${ }^{39}$ Transfer of Custodial Sentences Framework Decision (n 31), recital 4.

${ }^{40}$ Ibid recital 9.
} 
either the status of Union citizen or long term resident ${ }^{41}$ - a form of 'subsidiary' Union citizenship in many respects. ${ }^{42}$

\section{Conclusion:}

\section{National Responsibility for a Supranational Interest}

The European Arrest Warrant Framework Decision and the Framework Decision on the Transfer of Sentences establish a system for allocating responsibility between Member States for the imprisonment and ultimately social rehabilitation of individuals. In this sense it resembles and reflects one of the traditional functions of citizenship, namely the allocation of responsibility for particular individuals to a particular state. Under the system established under Union law the traditional criteria of nationality is not replaced. In fact, it is confirmed by the obligation on Member States to take back those of their nationals who face deportation. ${ }^{43}$ However, it is complemented by an additional criteria of membership or belonging based on the social ties an individual holds with a particular society. This has been achieved in light of the application of the rules of Union citizenship and in particular the principle of non-discrimination on the grounds of nationality and reflects the general model of Union citizenship as a status of integration that alters the configuration of national communities and the relationship between Member States and nationals of other Member States.

It will however be noted that there are limits to this assimilation hinted at in the Framework Decision on the Transfer of Sentences; individuals may only 'benefit' from the Framework Decision if they maintain a right to remain a resident of a state, a fact that has been echoed in the application of Articles 4(6) and 5(3) of the EAW FD. ${ }^{44}$ Both nationality and social integration operate in tandem to determine the appropriate state of responsibility for an individual. Originally, for the majority of Union citizens, it would be nationality, then after a sufficient period of time and process of integration in another Member State it would be the

\footnotetext{
${ }^{41}$ Ibid art 7(b).

42 Diego Acosta Arcarazo, The Long-Term Residence Status as a Subsidiary Form of EU Ctizenship: An Analysis of Directive 2003/109 vol 23 (Martinus Nijhoff 2011).

${ }^{43}$ Transfer of Custodial Sentences Framework Decision (n 31), art 4(1)(b).

${ }^{44}$ Kozlowski (n 15), Opinion of AG Bot, para 172 where he finds that the commission of criminal offences are only relevant for determining whether an individual is a resident for the purposes of Article 4(6) EAW FD where they lead to the issuing of an expulsion order under the Citizenship Directive. Similarly in Wolzenburg the Dutch rule requiring an individual to retain a right of residence in order to benefit from the national legislation implementing the EAW FD, is found to be compatible with Union law.
} 
criteria of social integration. However, as we shall see in the expulsion cases, treated in the next chapter, and in the residual provisions in the Transfer of Sentences Framework Decision, nationality can resurface as the allocating criterion in situations of particularly serious crimes that undo the process of integration and warrant expulsion.

While it is clear that the shape of the national community has been altered, it remains the national, rather than supranational community that is responsible for the rehabilitation of the offender; it is the national social context in which that rehabilitation takes place and it is the national community to which the individual seeks membership. Clearly, nationality still remains a defining criteria for identifying individuals, a criteria that only makes sense if the relevant unit into which an individual is to be reintegrated is in fact the national community. Similarly, the entire logic of both the line of caselaw dealing with Article 4(6) EAW FD and the Transfer of Sentences FD is premised on the fact that it is the national community, or at least a local part of it, that the individual enjoys certain connections. The economic, social, cultural and perhaps even linguistic connections and efforts at integration are directed at the host (ie national) society. As with the operation of the social integration dimension of Union citizenship generally, its operation in this context serves to preserve and highlight the role of national communities as the site of social existence, while at the same time altering their exclusive character and rendering their borders more porous.

At the same time, there are some indications that there is at least a Union-wide interest in the reintegration of Union citizens, making the Union as a whole a more socially cohesive and, by implication, a safer place. Rehabilitation tout court is cited as a goal of the EAW FD and indeed the Transfer of Sentences FD, not rehabilitation in the host society. It is simply that an individual is in a better position to be rehabilitated in a place closer geographically to his family connections and one with which he is culturally familiar. It is the individual interest, reflected and facilitated by Union law, that is at stake. Furthermore, the Court itself and Advocate General Bot have stressed in the context of expulsion cases that there is indeed a Union wide interest in the rehabilitation of offenders. In Tsakouridis the Court pointed out that Member States when deciding whether to expel an individual must be cognizant of 'the risk of compromising the social rehabilitation of the Union citizens... which...is not only in 
his interest but also in that of the European Union in general. ${ }^{45}$ The Advocate General on whose assessment the finding is based, highlighted the existence of freedom of movement; a circumstance that rendered the 'problem' of the offender and the 'solution' of his rehabilitation of concern not just to the host Member State and/or the state of nationality, but of the Union as a whole. ${ }^{46}$

Finally, we should not ignore the fact that in the operation of both of these instruments a Member State different to that which passes judgment carries out the sentence. While the calling to account for the wrong is done by the issuing Member State, it is the executing Member State that carries out the sentence. In effect the executing Member State is acting for the issuing Member State. For Duff punishment is essentially a communicative enterprise, in which the community expresses its disapproval of the wrongful conduct and attempts to enter into a processes of moral education of the offender. ${ }^{47}$ By delegating the carrying out of the sentence to the executing Member State, the issuing Member State delegates the communicative task of punishment to the executing Member State. The result is that the Member States collectively call to account and punish the individual concerned. The implication is that not only is there a collective, Union-wide interest in the rehabilitation of the offender but that there is a collective, Union-wide process of communicating disapproval.

It is not therefore simply a national matter, but rather a supranational question. It is through transnational processes, free movement and social integration, that render a criminal a supranational concern, that give rise to the possibility of a Union interest and goal in the rehabilitation of individuals and a collective Union-wide exercise in communication of disapproval for wrongful conduct. Responsibility for that rehabilitation is shared amongst the national communities of the Member States according to criteria linking an individual to a particular community; both nationality and social integration. The concept of rehabilitation, combined with the logic of social integration, has reshaped and reordered the traditional system of allocating responsibility for individuals to particular states, has

\footnotetext{
${ }^{45}$ Case C-145/09 Land Baden-Wurttemberg v Panagiotis Tsakouridis EU:C:2010:708, [2010] ECR I-11979 para 50 .

${ }^{46}$ Ibid Opinion of AG Bot para 95: 'Even if he is expelled from a Member State and prohibited from returning, when released the offender will be able, as a Union citizen, to exercise his freedom of movement in the other Member States. It is therefore in the general interests that the conditions of his release should be such as to dissuade him from committing crimes and, in any event not risk pushing him back into reoffending.'

${ }^{47}$ RA Duff, Punishment, Communication and Community (OUP 2003) $88 \mathrm{ff}$.
} 
rendered the borders of national communities more porous and has operated to reinforce the inclusion of a certain group of migrant Union citizens. At the same time it has also, indirectly, given rise to a shared goal amongst the Member States for the rehabilitation of individuals, both for their own interest and in the interest of the Union as a whole and a shared exercise in communicating disapproval through punishment. 



\title{
Chapter 4
}

\section{Social Integration II}

\section{Wrongdoing and a Supranational Duty of Respect}

\author{
Introduction \\ Integration, Rights and Duties
}

Citizenship of the Union is first and foremost a transnational status of social integration. The most important rights of Union citizenship, arising from the internal market, of free movement and non-discrimination, can be seen as reflecting a broader right to move to and become a member of another society within the European Union. It empowers individuals, from a migration status within the discretion of sovereign national law, to a transnational citizenship status guaranteed by autonomous supranational law. Individual Union citizens now stand in a different relation to the other Member States of the Union. The institution of Union citizenship renders the borders of national communities more porous and flexible and alters the principles that determine belonging within the European Union. ${ }^{1}$

The operational principle behind this process is that of social integration. ${ }^{2}$ The concept of social integration determines the relationship between the host Member State and the citizen. The rights of Union citizenship are intended to facilitate integration, in turn the more integrated an individual becomes the more rights he or she is entitled to. The goal is to firmly root an individual as a member in the society of another Member State. The operation of an exceptionally broad principle of non-discrimination in particular is intended to facilitate integration, ${ }^{3}$ but other aspects of Union citizenship including free movement based

\footnotetext{
${ }^{1}$ See Dora Kostakopoulou, 'European Citizenship: Writing the Future' (2007) 13 ELJ 623. See also Dora Kostakopoulou, Citizenship, identity and immigration in the European Union; Between Past and Future (Manchester University Press 2001).

${ }^{2}$ Loic Azoulai, 'La citoyenneté européenne, un statut d'intégration sociale' in Gérard Cohen-Jonathan and others (eds), Chemins d'Europe: Mélanges en l'honneur de Jean Paul Jacqué (Dalloz 2010).

3 See for example the rights of equal access to social services, labour rights and other welfare benefits guaranteed to migrant workers as early as 1968. See Regulation 1612/68/EEC on freedom of movement for
} 
rights, such as family reunification, are concerned with facilitating the social inclusion of an individual. ${ }^{4}$ This occurs in a material sense in allowing individuals to participate fully in the economic, social and even political life of the host society. ${ }^{5}$ It also operates in a symbolic fashion, by reducing instances where difference manifests between Union citizens and nationals. ${ }^{6}$ Social integration, in conjunction with the operation of a principle of proportionality and the principle of non-discrimination, has become the axis along which the extent of an individual's membership in the host society and hence the responsibilities of that society towards him or her, is measured. ${ }^{7}$

The relationship between rights and social integration is typically mutually reinforcing and progressive. Rights of free movement, residence and non-discrimination, access to the labour market and family reunification are granted to individuals in order to allow them to move to and engage in a process of integration into the host society. Union citizenship and in particular the status of permanent residence, is therefore intended to be 'a genuine vehicle for integration into the society of the host Member State. ${ }^{, 8}$ In turn the more integrated an individual becomes, the more rights he or she is entitled to. Or to put it more accurately, the less ability a Member State will have to legitimately discriminate against him or her in increasing areas of economic and social life. As well as being reinforcing, the relationship

workers within the Community [1968] OJ L 257/2, since replaced by Regulation 492/11/EU on freedom of movement for workers within the Union [2011] OJ L 141/1.

${ }^{4}$ See Case C-127/08 Metockv Minister for Justince Equality and Law Reform EU:C:2008:449, [2008] ECR I6241.

${ }^{5}$ See Council Directive 94/80/EC laying down detailed arrangements for the exercise of the right to vote and to stand as a candidate in munipal elections by citizens of the Union residing in a Member State of which they are not naionals [1994] OJ L 368/38 as amended by Council Directive 96/30/EC [1996] OJ L 122/14 and Council Directive 93/109/EC laying down detailed arrangements for the exercise of the right to vote and stand as a candidate in elections to the European Parliament for citizens of the Union residing in a Member State of which they are not nationals [1993] OJ L 329/34.

${ }^{6}$ Case C-524/06 Heinz Huber v Bundesrepublik Deutschland EU:C:2008:724, [2008] ECR I-9705. The logic being that in their interactions with the officials of Member States Union citizens are not to be classified as somehow 'other' and therefore more suspicious. See in particular the sentiments expressed by AG Maduro: 'the idea underlying the EU law provisions on citizenship and the right of entry and residence is that individuals should be able to integrate into the society of the host Member State and enjoy the same treatment as nationals, the system in question perpetuates the distinction between 'us' - the natives - and 'them' - the foreigners.' (Opinion of AG Maduro, para 15).

${ }^{7}$ Case C-209/03 The Queen (on the application of Dany Bidar) v London Borough v Ealing, Sec. of State for Education and Skills EU:C:2005:169, [2005] ECR I-2119. See further Ch 1. While there is a separate strand of case law that bases a citizen's inclusion on mere residence (See Gareth Davies, 'Any Place I Hang my Hat?' or: Residence is the New Nationality' (2005) 11 ELJ 43) this has been losing out to an increasingly 'qualitative' understanding of social integration as a means of regulating the boundaries of national communities and responsibilities of host Member States. See Daniel Thym, 'The Elusive Limits of Solidarity: Residence Rights of and Social Benefits for Economically Inactive Union Citizens' (2014) 52 CML Rev 17, citing in particular the judgment in Case C-333/13 Elisabeta Dano \& Florin Dano v Jobcenter Leipzig EU:C:2014:2358.

${ }^{8}$ Directive 2004/38/EC on the right of citizens of the Union and their family members to move and reside freely within the territory of the Member States [2004] OJ L158/77 (Citizenship Directive) preamble point (18). 
has, until recently, been seen as operating exclusively in a progressive manner; rights and integration increase with each other. Union citizenship can therefore be seen as the basis of an impressive set of transnational rights vis-à-vis other Member States; national rights guaranteed by supranational law $^{9}$ and operating according to a logic of integration. Like other forms of citizenship, it is a membership status complete with rights but it is one that operates within a unique political entity and one that functions primarily on a transnational basis.

Union citizenship therefore determines a set of rights and responsibilities between Union citizens and the host Member State. However, that relationship is curiously lop-sided with rights held primarily by the Union citizen and the responsibilities in turn held by the Member State. What Union citizenship conspicuously appears to lack is a set of duties. While the Treaty proudly declares that 'Citizens of the Union shall enjoy the rights and be subject to the duties provided for in the Treaties' ${ }^{10}$ the subsequent list contains no duties and commentators have struggled to find any other set of Union citizenship specific duties. ${ }^{11}$ The decline of citizenship duties is also apparent at a national level but at a Union level it is even more striking. Duties that may be considered 'citizenship-type' at a national level such as paying taxes, jury service, voting and military service do not have any analogy at a Union level. $^{12}$

However, perhaps attempting to locate the duties of Union citizenship at a supranational level is misguided. Union citizenship is a transnational status and it is through transnational processes that duties are most likely to be created. A series of cases dealing with the effect of criminal activity on Union rights have challenged both assumptions regarding Union citizenship: the progressive relationship between rights and integration and in turn the

\footnotetext{
${ }^{9}$ Paul Magnette, La Citoyennéte Européenne (Editions de l'Université de Bruxelles 1999).

${ }^{10}$ TFEU, art 20(2).

${ }^{11}$ See Dmitry Kochenov, 'EU Citizenship without Duties' (2014) 20 ELJ 482. Eleftheriadis does attempt to justify obligations individual citizens may have towards the Union and hence obedience to its laws as forming part of a general cosmopolitan duty to respect the legitimate moral creations (states and international organisations) of others. See Pavlos Eleftheriadis, 'Citizenship and Obligation' in Julie Dickson and Pavlos Eleftheriadis (eds), Philosophical Foundations of European Union Law (OUP 2012).

12 There is an argument that the Union levies taxes indirectly, in particular through its own resources. Similarly, whether the ability to vote in European Parliamentary elections could be considered a Union duty is open to question. It is unclear whether the European Parliament does in fact represent a European people or is simply an aggregation of representatives of national peoples. See Case C-145/04 Spain v UK EU:C:2006:543, [2004] ECR I-7902 and Joined Cases C-300/04 Eman and Sevinger v College van Burgemeester en Wethouders van Den Haag EU:C:2006:545, [2006] ECR I-8055 and comment by Jo Shaw, 'The Political Representation of Europe's Citizens: Developments' (2008) 4 EuConst 162.
} 
absence of duties on the part of Union citizens. Two areas in particular have been instrumental in this development: the interpretation of the new concept of 'imperative reason of public security' in expulsion cases and the effect of imprisonment on qualifying periods for residence rights under the Citizenship Directive. In assessing the effect of criminal activities on the integration process of particular individuals and the impact this may have on their rights under the Citizenship Directive the Court has fashioned a general duty of respect for the host society of the Member State. Social integration is therefore maintained as the principle by which the relationship between the individual the host Member State is regulated but, combined with a particular reading of criminal law, is used to rebalance it and impose obligations on Union citizens. While in appearance a duty under national law, this is in fact a distinct supranational duty, imposed by Union law and with consequences in Union law for the rights of Union citizenship; it is a supranational duty of respect for national communities.

\section{Crime as Wrong-Doing: Expulsion}

In two cases in particular, interpreting a new provision in the Citizenship Directive intending to provide additional protection for Union citizenship resident in other Member States for over ten years, the Court has in fact re-orientated the interpretation of the public policy and public security exception towards a normative perspective. This is even more apparent given the clear wording and expectations attached to Article 28(3) of the Citizenship Directive that spoke of threats to public security only.

\section{The Traditional View: Public Policy as Risk Minimisation}

Member States have always had the ability to expel Union citizens ${ }^{13}$ for having committed sufficiently serious crimes. The residual and exceptional power on the part of Member States to expel unwanted individuals was based on a catch-all public policy and public security derogation. For the most part considered synonymous, the terms are best understood as corresponding to the French term 'ordre public' - public order or more accurately public

\footnotetext{
${ }^{13}$ And before 1992 nationals of other Member States exercising rights as workers, self-employed or some other status. See Directive 64/221/EEC on the co-ordination of speacial measurs concernign the movement and residence of foreign nationals which are justified on grounds of public policy, public security or public health [1964] OJ L 117 since replaced by Citizenship Directive (n 8) ch VI.
} 
policy. ${ }^{14}$ The criminal law, as a set of imperative rules designed to security the rights and freedoms of individuals, ${ }^{15}$ is necessarily a part of public policy. ${ }^{16}$ All criminal laws are therefore rules of public policy, ${ }^{17}$ even if not all public policy rules are necessarily reflected in criminal law. ${ }^{18}$ Criminal law is a subset of public policy rules, but a significant subset. That the public policy and public security derogation contained in Union citizenship covers criminal acts is beyond doubt. ${ }^{19}$ Most of the instances of expulsion are based precisely on criminal conduct of individuals. As the Commission pithily puts it: the Citizenship Directive 'allows Member States to expel criminals'. ${ }^{20}$

While a prerogative of the Member States and a residue of the traditionally unlimited discretionary powers of the sovereign in this area, ${ }^{21}$ this power has always been circumscribed Union law. In particular, the principle of proportionality, in combination with the concept of social integration, has come to play an important role in its operation. ${ }^{22}$ The more integrated an individual, the more his or her interests would be harmed by expulsion and a greater risk would be required in order to expel him or her. ${ }^{23}$ The use of the

\footnotetext{
${ }^{14}$ Perhaps not directly translatable see Case C-554/13 Z, Zh \& O v Staatssecretaris van Veiligheid en Justie (Opinion of AG Sharpson, 12 February 2015) para 33. For an overview of the use of the concept in Union law see Georges Karydis, 'L'ordre public dans l'ordre juridique communautaire: un concept à contenu variable ' [2002] RTD eur 1.

${ }^{15}$ For such an account of ordre public see Etienne Picard, 'La Fonction de l'Ordre Public dans l'Ordre Juridique' in Marie-Joëlle Redor (ed), L'ordre public: Ordre public ou ordres publics? Ordre public et droits fondamentaux (Bruylant 2001).

${ }^{16}$ Agnes Cerf, 'Ordre Public, Droit Pénal et Droits Fondamentaux' in Marie-Joëlle Redor (ed), L'odre public: Ordre public ou ordres publics Ordre public et droits fondamentaux (Bruylant 2001).

${ }^{17}$ See $Z, Z H \& O$ (n 14): '[t]he rules of criminal law are all [public order] rules in the sense that they are imperative rules... a breach of a Member State's criminal law therefore equates to an act contrary to [public order].' (paras 61-62).

${ }^{18}$ See Case 41/74 van Duyn v Home Office EU:C:1974:133, [1974] ECR 1337 concerning a public policy related to limitations on the Church of Scientology. More recently see E-15/12 Jan Anfinn Wahl v the Icelandic State (Court of the EFTA, 22 July 2013) relating to a similar policy with respect of the Hell's Angels Motorcycle group. Note that although not relating to directly criminalized acts or organisations there must be some objective evidence of a stated policy on the part of the Member State concerned.

${ }^{19}$ Although note not all threats to public order and hence not all crimes will fall within the derogation; threats need to reach a certain level of seriousness. See $Z, Z H \& O$ (n 14) Opinion of AG Sharpston.

${ }^{20}$ Report from the Commission to the European Parliament and the Council on the application of Directive 2004/38/EC on the right of citizens of the Union and their family members to move and reside freely within the territory of the Member States COM(2008) 840 final 7.

${ }^{21}$ See Gérard Lyon-Caen, 'La réserve d'ordre public en matiere de liberé d'etablissement et de libre circulation' (1966) RTD Eur 693.

${ }^{22}$ Another important limitation is the definition of what constitutes public policy or public security. While it is a national concept to be defined in terms of national laws it must comply with a general EU law condition that it be a 'genuine and sufficiently serious threats to the requirements of public policy affecting one of the fundamental interests of society.' See Case 30/77 Regina v Bouchereau EU:C:1977:172, ECR [1977] 199 para 35 .

${ }^{23}$ The inclusion of the proportionality principle within the law on expulsion of Union citizens was contained in the Opinion of AG Pergola in Case C-348/96 Criminal Proceedings against Donatella Calfa EU:C:1999:6, [1999] ECR I-11 and could be said to be implicit in the Court's judgment. It was explicitly and in a detailed
} 
proportionality principle in this fashion draws explicitly and extensively from the caselaw of the European Court of Human Rights (ECtHR) on the right to respect for family and private life found in Article 8 of the European Convention on Human Rights (ECHR). ${ }^{24}$ It is also coherent with the general view of Union citizenship based on social integration and the mutually reinforcing and progressive relationship between social integration and rights of an individual migrant; the more integrated, the more links, familial, social, economic etc, one has established with the society of the host Member State, the more disproportionate an expulsion decision would be and the greater protection one enjoys from expulsion. The use of proportionality in this context therefore neatly dovetails with the overall operation of Union citizenship as a transnational status of social integration.

It is important to note that in this view criminal law and in particular breaches of the criminal law are seen primarily as risks to public policy or public order; it is a harm based and future orientated assessment. Criminal activity is seen as disturbing public order and the security and safety of citizens. Sufficiently serious breaches of the criminal law are seen as manifesting threats on the part of the individual concerned to public policy and public security. It is the present threat posed (threat being a future and probability orientated assessment), rather than the past conduct that is important. The previous criminal convictions of an individual are relevant, but only insofar as they indicate a propensity to commit crimes in the future. ${ }^{25}$ The Court speaks of the 'danger which the person represents' ${ }^{26}$ Under this version of the proportionality assessment the social integration and the risk posed by the individual are balanced against each other as competing interests. To borrow from the ECrHR's jurisprudence on which the Court of Justice draws: '[t]he Court's task consists in ascertaining whether in the circumstances the refusal to renew the applicant's residence permit struck a fair balance between the relevant interests, namely the applicant's

fashion outlined by the Court in Joined Cases C-482/01 and C-493/01 Georgios Ofanopoulos et al and Raffaele Oliveri v Land Baden-Würtemberg [2004] ECR I-5257 in which the Court stated that 'the necessity of observing the principle of proportionality must be emphasized. To assess whether the interference envisaged is proportionate to the legitimate aim pursued, in this instance the protection of public policy, account must be taken, particularly of the nature and seriousness of the offences committed by the person concerned, the length of his residence in the host Member State, the period which has elapsed since the commission of the offence, the family circumstances of the person concerned and the seriousness of the difficulties which the spouse and any of their children risk facing in the country of origin of the person concerned.' (para 99).

${ }^{24}$ See Boultif v Switzerland ECHR 2001-IX. See also Maslov v Austria App no 1683/03 (ECrtHR, 23 June 2008). For a critical discussion of the ECtHR's caselaw in the area see Colin Harvey, 'Promoting Insecurity: Public Order Explusion and the ECHR' in Elspeth Guild and Paul Minderhoud (eds), Security of Residence and Expulsion: Protection of Aliens in Europe (Kluwer International 2001).

${ }_{25}$ Although the past conduct may be relevant in assessing the present threat see Bouchereau (n 22) para 29.

${ }^{26}$ Calfa (n 23) para 26. 
right to respect for his family life, on the one hand, and the prevention of disorder or crime, on the other. ${ }^{27}$ Social integration, and in particular the bonds created between the migrant individual and the host society be they familial, social or economic, are not undone or negated by the criminal act or the perceived threat to public policy and public security. Rather the threat or harm to one outweighs the harm to the other; it is simply a balancing exercise.

The operation of public policy and in particular the executive discretion associated with it, is one of the main areas in which nationals differ from aliens. ${ }^{28}$ One could therefore be forgiven for thinking that with the advent of Union citizenship, in theory a legally reinforced and politically symbolic membership status different in kind from alienship, the discretion afforded Member States with respect to Union citizens would be further restricted and circumscribed. ${ }^{29}$ This was the Commission's perspective, even before the adoption of the new Citizenship Directive, ${ }^{30}$ who in a Communication of 1999 noted that ' $[\mathrm{t}$ ] he new concept of citizenship of the Union should play a role in the overall assessment of the position of a Union citizen in case national authorities consider his/her expulsion or non-admission for reasons of public order, public security or public health. Article 18 of the EC Treaty [now Article 21 TFEU] should be accorded its full weight by national authorities when they contemplate the application of Directive 64/221/EEC to a Union citizen. ${ }^{31}$ Indeed, in its comparison with third country nationals and in particular Turkish nationals, the Court did appear to recognise a new paradigm in expulsion cases instituted by the introduction of the concept of Union citizenship ${ }^{32}$ and in one case immediately before the transposition of the Citizenship Directive it invoked the oft-repeated formula of Union citizenship as the fundamental status of nationals of Member States. ${ }^{33}$

\footnotetext{
${ }^{27}$ Boultif $v$ Switzerland (n 24) para 47.

${ }^{28}$ Lyon-Caen (n 21) 693-694.

${ }^{29}$ The separate question of extending the protections offered by Directive 221/64/EEC to all Union citizens and not simply the economically active was addressed by the Court in Case C-50/06 Commission v Netherlands [2007] ECR I-04383 that did in fact extend the scope of the Directive.

${ }^{30}$ Citizenship Directive (n 8).

${ }^{31}$ European Commission, Communication on the Special Measures concerning the Movement and Residence of Citizens of the Union which are Justified on Grounds of Public Policy, Public Security or Public Health (COM(1999) 372 final, 1999). With the implication perhaps that similar considerations would not apply to other individuals covered by the directive, notably family members of Union citizens.

${ }^{32}$ Case C-371/08 Nural Ziebell $v$ Land Baden-Wurtenmburg EU:C:2011:809: 'It thus follows from the substantial differences to be found not only in their wording but also in their object and purpose between the rules relating to the EEC-Treaty Association and European Union law concerning citizenship that the two legal schemes in question cannot be considered equivalent...' (para 73).

${ }^{33}$ Ofanopoulous \& Oliveri (n 23) para 65.
} 
This new, increased protection by virtue of the nature of Union citizenship, appeared to be also reflected in legislative developments with the Citizenship Directive introducing a new, graduated and improved system of protection for Union citizens and in particular those of longer residence in the host society. This new system reflected the principle of proportionality and its application in light of the concept of social integration. ${ }^{34}$ Three groups of Union citizens were established: a general category could be expelled for reasons of public policy and public security; ${ }^{35}$ a second category that held permanent residence could be expelled only for 'serious reasons of public policy and public security' ${ }^{36}$ and a final category consisting of Union citizens resident for 10 years or more and minors could be expelled only for 'imperative reasons of public security'. ${ }^{37}$ It will be noted that for the final category the Union legislature differentiated both in terms of degree and kind; the threat was to be more serious ('imperative') and it was also to be restricted to threats to public security, excluding reasons of public policy. The Commission for its part emphasised this distinction in its guidance on the implementation of the Directive stressing that '[i]t is crucial that Member States define clearly the protected interests of society, and make a clear distinction between public policy and public security. The latter cannot be extended to measures that should be covered by the former. Public security is general interpreted to cover both internal and external security along the lines of preserving the integrity of the territory of the Member State and its institutions. Public Policy is generally interpreted along the lines of preventing disturbance of social order.' (emphasis in original) ${ }^{38}$ Thus while public policy might, in certain circumstances, refer to the public morality of a Member State, ${ }^{39}$ it would appear that public security would not. However, in its interpretation of the provision, the Court of Justice has taken a remarkably different approach.

\section{Public Security as Values}

In a pair of cases, dealing with the question of the expulsion of two Union citizens from Germany, the Court of Justice has interpreted Article 28(3) of the Citizenship Directive in a

\footnotetext{
${ }^{34}$ Citizenship Directive (n 8) preamble point 23.

35 Ibid, art 28(1).

${ }^{36}$ Ibid, art 28(2).

${ }^{37}$ Ibid, art 28(3).

${ }^{38}$ Communication from the Commission to the European Parliament and the Council on guidance for better transposition and application of Directive 2004/38/EC on the right of citizens of the Union and their family members to move and reside freely within the territory of the Member States COM(2009) 313 final, 10.

${ }^{39}$ See for example van Duyn (n 18).
} 
strikingly different manner to that suggested by the Commission or a plain reading of the text. ${ }^{40}$ In a nutshell, it has interpreted pubic security in normative terms, allowing it to be defined as reflecting the fundamental interests of the society of a Member State based on its particular values and has allowed a moral assessment of the individual's conduct to be used as a basis for his or her expulsion. In Tsakouridis the individual in question had been resident in Germany since birth with the exception of two brief periods during which he returned to Greece, the country of his nationality. After a number of convictions for petty crimes he was convicted for six years for drug possession and membership of a criminal organisation. ${ }^{41}$ In $P I$, an expulsion order was made following Mr I's conviction for continuous sexual abuse of his young step-daughter over a seven year period. ${ }^{42}$ In both cases what was at stake was the interpretation of new formula 'imperative reasons of public security' as distinct from simply 'public policy and public security'. Though its judgments, and in particular in a number of shifts between Tsakouridis and PI, the Court of Justice has interpreted imperative reasons of public security in terms of the host society's values: it has focused not on potential harm to the integrity of the Member State and its institutions or its territorial integrity but rather on the wrongness and blameworthiness of the individual's actions.

Three shifts between Tsakouridis and PI contribute to this new understanding of 'public security'; the collapse of any distinction between the concepts of public security and public policy and the consequential extension of the definition of public policy to cover public security; the definition of seriousness in terms of the blameworthiness of the act rather than any threatened harm and finally the individualised rather than systemic nature of the threat, a harm and wrong that while directly experienced by the individual is nonetheless shared by the host society. Together they point to a reorientation of the understanding of the expulsion power of Member States from a security measure aimed at future harms to a technique for imposing a general duty of respect for the host society's values.

Firstly, in $P I$ the Court abandons any attempt to make a conceptual distinction between the notions of public policy and public security, instead defining both as reflecting the 'fundamental interests of society' as arising from the particular values of the Member State in question. As noted above, Article 28(3) of the Citizenship Directive appears to make a

\footnotetext{
${ }^{40}$ See Georgios Anagnostaruas, 'Enhanced Protection of EU Nationals against expulsion and the concept of internal public security: Comment on P.I.' (2012) 37 ELRev 627.

${ }^{41}$ Case C-145/09 Land Baden-Wurttemberg v Panagiotis Tsakouridis EU:C:2010:708, [2010] ECR I-11979.

${ }^{42}$ Case C-348/09 PI v Oberbürgermeisterin der Stadt Remscheid EU:C:2012:300.
} 
distinction in both degree and kind between public policy and public security on the one hand and imperative reasons of public security on the other. In Tsakouridis, the Court appears to endorse this difference in kind noting that public security specifically refers to 'the functioning of institutions and essential public services and the survival of the population'. ${ }^{43}$ However, in its application to the threat in question - drug trafficking - the Court gives it particularly wide scope, noting the systemic economic and social threats that drug trafficking (along with organised crime) poses to the "population as a whole or a large part of it' ${ }^{44}$ In $P I$ however the Court abandons any attempt to maintain a definitional distinction between its previous definition of public policy and public security and public security simpliciter. An imperative threat to public security is simply one that threatens a fundamental interest of society and the calm and physical security of the population (note how the caveat 'as a whole or a large part' is dropped). ${ }^{45} \mathrm{~A}$ threat to a 'fundamental interest of society' is the classic formula employed by the Court over decades in the context of expulsions for reasons of public policy. ${ }^{46}$ One would have expected a ground for expulsion based on public security alone to be different. The result is that 'public security' is to be defined according to the particular values of the host society. The only difference is that in order to invoke Article 28(3) of the Citizenship Directive, a Member State must establish 'a particularly serious' threat, something flowing from the imperative quality of such a reason.

That seriousness however appears to be defined in terms of the moral blameworthiness of the individual and his act rather than the degree of harm or threat he may pose. An ambiguity existed in Tsakouridis on this point; on the one hand the Court noted that 'drug addiction represents a serious evil for the individual' ${ }^{47}$ On the other hand there was a concerted effort on the part of the Court to present drug trafficking (again linked to organised crime) as an activity that presented serious harms both to individuals and society at large. ${ }^{48}$ That ambiguity diminishes significantly in $P I$. The conduct of the individual in question is

\footnotetext{
${ }^{43}$ Tsakouridis (n 41) para 44.

${ }^{44}$ Ibid para 47.

${ }^{45} P I$ (n 42) para 28.

${ }^{46}$ Bouchereau (n 22) para 35. For an account see Niamh Níc Shuibhne, 'Derogating from the Free Movement of Persons. When can EU citizens be deported?' (2005-2006) 8 Cambridge Yearbook of European Legal Studies 187, 188-193.

${ }^{47}$ Tsakouridis (n 41) para 44.

${ }^{48}$ Ibid para 46 with the Court referring to the preamble of the Framework Decision on Drug Trafficking which in turn notes the threat posed by drug trafficking to 'health, safety and the quality of life of citizens of the Union and to the legal economy, stability and security of the Member States.' See Framework Decision 2004/757/JHA laying down minimum provisions on the constituent elements of criminal acts and penalties in the field of illicit drug trafficking [2004] OJ L 335/8, preamble point (1).
} 
regarded as particularly serious for a variety of reasons that stem more from the abhorrent and wrongful nature of the crime rather than the physical harm or certainly the future threat posed. The sexual exploitation of children is noted as a serious violation of the rights of children, as was the fact that it was committed against a minor and the fact that the perpetrator of the crime was in a position of responsibility. ${ }^{49}$ In its description of the case, relying on the referral from the national court, the Court of Justice notes the continuous suffering endured, the brutal nature of the crime and the perpetrator's apparent lack of remorse. ${ }^{50}$ Some of these factors may be construed as elements pointing to the potential threat that Mr I continues to pose to the safety of other young girls and women. However, they are principally used to determine the blameworthiness of the crime in terms of past harm caused and moral culpability. There is an undeniable moralistic undertone in the Court's consideration of Mr I's conduct throughout the judgment. The seriousness appears to be related to the blameworthiness of Mr I's actions - his mental state and culpability - rather than to any propensity for future harm. The suffering of the victim was indeed great and the culpability of Mr I clear. These point to the seriousness of the act certainly, but in terms of blameworthiness, rather than potential harm to the broader population.

Indeed, the third shift from Tsakouridis to PI is the individualised nature of the threat; the threat only impacted on a single individual rather than society as a whole. ${ }^{51}$ It would appear that Mr I was not part of a broader network, nor is there any evidence to suggest that he committed similar crimes outside the confines of the family home. The implication is that Mr I did not, nor would not, pose any threat outside that rather narrow context. ${ }^{52}$ In Tsakouridis the Court appears at pains to stress the systemic nature of drug trafficking as a crime, one with wide-ranging economic and social consequences beyond the immediate victims, a 'diffuse crime'. 53 In $P I$ on the other hand, as noted by AG Bot, the crime did not present similar characteristics. Mr I was not part of a broader network, it was not an instance of the sexual abuse of children linked to the broader phenomenon of human trafficking, nor was it related to child pornography and its wider dissemination. There was no indication that

\footnotetext{
${ }^{49} P I$ (n 42) paras 26-27.

${ }^{50}$ Ibid paras 11-13.

51 Note this is to be distinguished from the origin of the threat: there must always be an individualized assessment of the threat posed by a particular individual. General measures of deterrence or general policies of deporting following a sentence of a particular length are not permitted. See Bouchereau (n 22).

${ }^{52}$ PI (n 42) Opinion of AG Bot para 44.

${ }^{53}$ Tsakouridis (n 41) para 46.
} 
this was part of a broader threat to 'the population as a whole' as in Tsakouridis, rather the harm done and the supposed threat posed was to an individual.

However, while targeted against an individual victim, it is important to note the social and public dimension of this wrong. The direct harm and suffering is borne by the individual in question, however it is framed by the Court in terms of an assault on the 'fundamental interests of the society' in question based on 'its particular values'. These two positions can be reconciled by an appeal to the concept of 'shared wrongs' ${ }^{54}$ It is through the suffering of the individual that society, in this case the Member State's society, is wronged. Through common membership, the public as a whole shares the wrong arising from the harm suffered directly by the individual; by harming one in such a serious and wrongful manner the moral outrage is felt by all. This is different from a generalised threat of harm to the population but it does render the private harm a public wrong.

These three points - defining public security in terms of the fundamental interest of society; defining seriousness in terms of the blameworthiness of the act and allowing the derogation to be used in instances where the harm is to an individual rather than society - all point to a view of public security and the criminal law that is normative and defined in terms of values. It is not the harm or threat of harm caused to the state, its institutions or indeed the general population that is at stake. What is at stake is the offence caused by the perpetrator towards the host society by his wrongful acts and through the individual harm society as a whole is offended. It therefore appears to mark a shift from the previous conceptions of threats to public policy and public security and proportionality. ${ }^{55}$

The consequence of defining imperative reasons of public security in such terms is clear: the acts of the individual are seen as an offence against the community and a violation of its particular normative code as reflected in its criminal law. As a result that citizen can be expelled, or to use a more emotive language more appropriate to citizenship, exiled or banished. That exile is only understandable by placing this understanding of crime within the concept of social integration. Implicit in the judgment, and explicit in the Opinion of AG Bot

\footnotetext{
${ }^{54}$ See RA Duff and SE Marshall, 'Criminalization and Sharing Wrongs' (1998) 11 CJLJ 7.

${ }^{55}$ Again taking into account the limited existence of some cases of expulsion based on public morality. See van Duyn (n 18) and Joined Cases 115/81 and 116/81 Adoui and Cornuaille v Belgium EU:C:1982:183, [1982] ECR 1665. In the context of the free movement of goods see Case 34/79 Regina v Maurice Donald Henn and John Frederick Ernest Darby EU:C:1979:295, [1979] ECR 3795.
} 
in $P I$, is a new understanding of the relationship between integration and criminal acts. The threat posed by the individual is no longer weighed against his or her integration as two competing but separate interests such that one balances out the other as is implied by the previous caselaw of the Court of Justice and of the ECrHR. There is a closer, more causal relationship between integration and criminal activity rather than a mere accounting exercise. The implication is that his or her criminal acts evidence a failure to integrate in the first place or indeed undoes any integration that may have been achieved. If the individual's membership status is regulated according to his degree of integration then by breaching the particular society's moral code and offending the host society, he or she demonstrates an attitude inimical to social integration. In the words of AG Bot: 'Mr I's conduct, which constitutes a serious disturbance of public policy, shows a total lack of desire to integrate into the society in which he finds himself and some of whose fundamental values he so conscientiously disregarded for years. ${ }^{56}$ While the Court does not go so far as to draw that conclusion explicitly, its insistence on basing public security on the values of the host society and measuring seriousness in terms of blameworthiness reaches the same result. Rather than precluding a culpable individual from acquiring the status as proposed by the AG, it simply allows his blameworthiness to overcome the protection that status supposedly offers.

\section{Wrong-Doing and Integration: Residence Rights}

What was implicit in $P I$ becomes explicit in cases dealing with the acquisition of residence rights by migrant Union citizens and in particular the effect of periods of imprisonment on the calculation of qualifying periods for permanent residence and the heightened protection found in Article 28(3) of the Citizenship Directive. In Onuekwere the Nigerian husband of a migrant Union citizen sought permanent residence in order to benefit from the intermediate level of protection from expulsion contained in Article 28(2) of the Citizenship Directive. National authorities however refused his application on the grounds that periods he spent in prison not only did not count towards the qualifying period of five years for permanent residence, ${ }^{57}$ but in fact broke the continuity of any such period. ${ }^{58}$ In $M G$, decided on the

\footnotetext{
${ }^{56}$ Tsakouridis (n 41) Opinion of AG Bot para 60. Continuing to remain in a particular society while so flaunting its values amounts to a kind of abuse of rights or fraud according to the AG.

${ }^{57}$ Citizenship Directive (n 8) art 16.

${ }^{58}$ Case C-378/12 Nnamdi Onuekwere v Secretary of State for the Home Department EU:C:2014:13.
} 
same day, the Court made a similar finding in relation to a Union citizen seeking the heightened protection stemming from a ten year residence period and relying on the reasoning of Onuekwere. Mrs MG, having spent time in prison for the physical abuse of her children, was found not to be automatically eligible for the protection of Article 28(3) of the Citizenship Directive despite residence of more than ten years. ${ }^{59}$ In both judgments, in a rather strident tone, the Court explicitly adopted a view of the criminal law as both normative (a code of values) and as communitarian (of the host society). Combining this with an understanding of the rights of Union citizenship as a reward for a prior experience of integration, allowed the Court to come to the conclusion that criminal acts resulting in imprisonment either demonstrated a failure to integrate or undid or cancelled out any integration that may have taken place. ${ }^{60}$

Prompted by a strong opinion from AG Bot, the Court in Onuekwere adopts an unambiguously normative view of the criminal law. The criminal law is seen as reflecting core values of a particular society and indicating the imperative rules of conduct individuals are to adopt in relation to each other and the community at large. There is no attempt to conceptualise the criminal law in term of harm or risk posed by an individual. Indeed, the normative basis of criminal law informs not only the basis of criminalisation but also the justification for punishment - both retributive and rehabilitation goals reinforce each other within a normative paradigm of crime and punishment. For AG Bot, imprisonment is 'a period spent atoning for the crime committed', ${ }^{61}$ a language remarkably close to Duff's account of punishment as 'secular penance'. ${ }^{62}$ Rehabilitation is necessary precisely because the individual has disregarded the value system of the host society (and hence failed to integrate) -reflecting what Hart has termed the role of imprisonment to teach 'responsible citizenship'. ${ }^{63}$

This view of the criminal law is not only normative but it is communitarian. The criminal law is a public law and it is one given by the community to itself; a 'common law' in the

\footnotetext{
${ }^{59}$ Case C-400/12 Secretary for State for the Home Department v MG EU:C:2014:9. The exact determination to be made by the national court.

${ }^{60}$ This section is draws on a previous publication. See Stephen Coutts, 'Union Citizenship as Probationary Citizenship: Onuekwere' (2015) 52 CML Rev 531.

${ }^{61}$ Onuekwere (n 58) Opinion of AG Bot para 54.

${ }^{62}$ RA Duff, Punishment, Communication and Community (OUP 2003) 106.

${ }^{63}$ Heny M Hart, 'The Aims of Criminal Law' 23 LCP 401, 437.
} 
literal sense of the word. ${ }^{64}$ For the Court it represents 'the values expressed by the society of the host Member State'. ${ }^{65}$ In the eyes of AG Bot the criminal law 'reflects the laws and values of...society. ${ }^{, 66}$ Moreover it is linked to the notion of citizenship in particular: [n]eed it be recalled...that citizenship is for the citizen a guarantee of belonging to a political community under the rule of law? ${ }^{67}$ Criminal law reflects duties that individuals owe to each other as members of a political community governed by law, the content of which arises from shared values; a clear endorsement of Duff's view of the criminal law.

This then is combined with a particular reading of Union citizenship and the role of integration in the acquisition of rights under the Citizenship Directive. On the one hand the 'qualitative dimension' of integration is emphasised. On the other hand the causal relationship between integration and rights is reversed. Integration is seen as not merely temporal and geographical - ie mere presence in the host Member State for a certain period of time - but as also having 'qualitative elements'. ${ }^{68}$ The term is borrowed from jurisprudence dealing with requirements of economic activity or self-sufficiency and arguably originally conceived of in the context of balancing the right migrant Union citizens to equal treatment with the hosts Member State interest in them not becoming an 'unreasonable burden'. ${ }^{69}$ What Onukwere does is take this material condition of economic contribution and transform it into a normative condition of respect for the values of the host society. There is also a shift in the relationship between integration and rights; whereas previously rights were seen as forming the basis for integration - allowing the migrant to participate fully in the life of the host Member State and hence become integrated - now rights, and in particular the rights associated with permanent residence, are seen as the reward for previously achieved integration; its acquisition is 'subject to the integration of the citizen of the Union in the host Member State'. ${ }^{70}$

The final piece of the reasoning of the Court is the link between integration and crime. Crime is seen as inimical to the values of the host society and represents a repudiation of its

\footnotetext{
${ }^{64}$ In Duff's words a true 'common law', RA Duff, Answering for Crime: Responsability and Liability in the Criminal Law (Hart 2007) 49.

${ }_{65}$ Onuekwere (n 58) para 26. See also $M G$ (n 59) para 31.

${ }^{66}$ Onuekwere (n 58) Opinion of AG Bot para 46.

${ }^{67}$ Ibid Opinion of AG Bot para 52.

${ }^{68}$ Ibid Judgment of the Court of Justice para 24.

${ }^{69}$ Case C-325/09 Secretary of State for the Home Department v Maria Dias EU:C:2011:498, [2011] ECR I6387.

${ }^{70}$ Onuekwere (n 58) para 24.
} 
moral code: 'a transgression of the societal norms of the host Member State'. ${ }^{71}$ In making this point, is important to highlight that it is not the period of imprisonment that concerns the Court or the Advocate General but the underlying crime ie the blameworthy act. The Court could very easily have decided that imprisonment amounted to a form of 'internal exile', a place socially and to an extent geographically removed from society, literally a place apart, and in which normal links with the broader society would be undermined or fail to form. Indeed this is the solution that was suggested implicitly by the German government who proposed that periods of imprisonment be treated analogously to periods spent abroad when deciding whether they break the continuous nature of the residence of an individual. ${ }^{72}$ The Court rejected that suggestion and indeed the Advocate General went even further, indicating that sentences of a quasi-custodial nature, such as partial release or supervision orders, should similarly be considered as breaking the integration links and hence preventing an individual from acquiring permanent residence. ${ }^{73}$ It is not therefore the absence of the individual that is at stake, rather it is the underlying wrongful act and hence responsibility as a moral actor in his or her dealings with the community. Furthermore, not only does criminal activity prevent integration taking place but in fact works to undo integration. This is evidenced by the finding that not only does criminal activity not count towards periods of residence but in fact breaks the continuity of any such periods; in the word of AG Bot any previously acquired integration is 'expunged' by the criminal conduct. ${ }^{74}$

The conclusion from these premises - rights are the reward for integration; integration requires respect for values; crime represents a disrespect for values - is that criminal activities preclude an individual from acquiring rights under the Directive, either permanent residence in the case of Onuekwere or heightened protection in the case of $M G{ }^{75}$ There is an impact on membership and duties and the relationship between them. Permanent residence in particular 'goes beyond the mere right to reside and move within the territory of the European Union. It can create, for Union citizens, a feeling of being fully part of the society

\footnotetext{
${ }^{71}$ Ibid Opinion of AG Bot para 64.

${ }^{72}$ Ibid Opinion of AG Bot para 60.

${ }^{73}$ Ibid Opinion of AG Bot para 56.

${ }^{74}$ Ibid Opinion of AG Bot para 54.

${ }^{75}$ Although it should be noted that in MG the Court finds that an overall and individualized assessment of the individual's level of integration in the society of the host society should be undertaken, criminal activity and its prejudicial effect on integration, being one element of that overall assessment. Indeed it is worth questioning the value of a bright line rule of ten years, if it is to be supplemented by such an ad hoc assessment of the individual situation of the convicted Union citizen.
} 
of the host Member State'. ${ }^{76}$ That 'being fully part of society' however is conditioned on a normative commitment, one that requires acceptance and respect for the values of that society, an identification with the morals of the host society and a sharing of their worldview - or at least those elements that are reflected in their criminal law. ${ }^{77}$ Failure to respect those values results in exclusion, in a rejection of the membership promised by permanent residence and the maintenance of otherness. This exclusion of those deemed criminally deviant from membership in the community is not unique to Union law, ${ }^{78}$ although perhaps the explicit, rather than implicit, manner in which it operates is. ${ }^{79}$ What it represents is the appropriation of a certain tendency and a view of criminal law, exclusion and the community, and imports it within the workings of Union citizenship through the use of a normative view of criminal law within the operation of the social integration paradigm.

\section{Conclusion}

\section{A Supranational Duty of Respect towards National Communities}

From these series of cases the Court has in fact used the concept of social integration inherent in Union citizenship and combined it with a normative and communitarian view of the criminal law to establish a set of duties for migrant Union citizens. However, while it may appear that the duty is of a passive and national character, it is in fact a more active, positive duty and one that is rooted in supranational law. There is therefore a combination of the transnational and supranational in constructing duties for Union citizens in this area. It is through national criminal law that the Union constructs a supranational duty which in turn is a duty of respect towards national communities.

\section{National Communities}

The content of the duties is to be found in national law and reflects national values. In both sets of cases the Court is at pains to emphasise that it is national criminal law that is at stake.

\footnotetext{
${ }^{76}$ Onuekwere (n 58) Opinion of AG Bot 44.

${ }^{77}$ See the view of the Bundesverfassungsgericht in Ratification of the Treaty of Lisbon, Re (2 BvE 2/08) [2010] CMLR 13 (Bundesverfassungsgericht) para 331 discussed further in ch 6.

${ }^{78}$ Lucia Zedner, 'Is the Criminal Law Only for Citizens? A Problem at the Borders of Punishment' in Mary Bosworth and Katja Franco Aas (eds), The Borders of Punishment: Migration, Citizenship and Social Exclusion (OUP 2013) and Barbara Hudson, 'Punishing Monsters, Judging Aliens: Justice at the Borders of Community' (2006) 39 Austrialian and New Zealand J of Criminology 232.

79 Although see the recent turn towards denationalization for certain terrorist related offences see Audrey Macklin and Rainer Bauböck, The Return of Banishment: Do the New Denationalisation Policies Weaken Citizenship? (EUI Working Papers, RSCAS 2015/14, 2015).
} 
In Onuekwere there is no attempt on the part of either the Court or the Advocate General to impose any conditions flowing from Union law on what counts and what does not count as a 'wrong' for the purposes of deciding whether an individual has failed to integrate or otherwise. ${ }^{80}$ In fact it is very clear that the criminal law is a code that reflects the national society's set of values: [t]he imposition of a prison sentence by the national court is such as to show the non-compliance by the person concerned with the values expressed by the society of the host Member State in its criminal law' ${ }^{81}$ Its wrongful character arises from the fact that it has been classified as such under national criminal law. The jurisprudence in the expulsion cases is also clear in emphasising the role of Member States in defining public policy and public security. These are seen as derogations from Treaty obligations and exceptions that reflect particular national interests and values. ${ }^{82}$ It is the 'fundamental interests of the host society' that may 'vary from one country to another and from one period to another'. ${ }^{83}$ 'Member States essentially retain the freedom to determine the requirements of public policy and public security' and 'European Union law does not impose on Member States a uniform scale of values as regards the assessment of conduct which may be considered to be contrary to public security,. ${ }^{84}$ This is particularly striking in the definition of public security, a concept one would imagine would be objective and unchanging between societies.

Not only does the content of the duty of respect arise from national law but the target of the duty is also the national community. A crime is not a blameworthy act in a vacuum; it is committed against someone or something - it is a relational concept. Responsibility implies that we are answerable to someone for our actions. ${ }^{85}$ In the cases analysed it is a crime committed against the national community. It is the relationship between the individual and the host society that is at stake; the transnational relationship that stems from the primarily

\footnotetext{
${ }^{80}$ Except perhaps wrongs that result in custodial sentences, a requirement that flows more from the nature of the preliminary reference rather than anything inherent in the Court's reasoning.

${ }^{81}$ Onuekwere (n 58) para 26.

${ }^{82}$ Although see certain critiques of the Court's jurisprudence in the broader question of public policy exceptions as not in fact leaving any autonomous space for Member States to define their own, distinctive public policy see Catherine Kessedjian, 'Public Order in European Law' (2007-2008) 1 Erasmus Law Review 25. However, it is submitted that there is a distinction between the Union exercising a certain negative control - ie ensuring that Member States do not invoke public policy reasons that would be contrary to the values of the Union - from a more positive control - ensuring that Member States can only invoke public policy reasons that conform to a Union wide understanding of public policy. Indeed such would seem to be the approach followed by the Court in, for example, Case C-36/02 Omega Spielhallen- und Automatenaufstellungs-GmbH v Oberbürgermeisterin der Bundesstadt Bonn EU:C:2004:614, [2004] ECR I-9609.

83 van Duyn (n 18) para 18.

${ }^{84} P I$ (n 42) paras 21-23.

${ }^{85}$ See in particular Duff, Answering for Crime: Responsability and Liability in the Criminal Law (n 64) ch 2.
} 
transnational character of Union citizenship. This is why it is perfectly logical to expel or exile an individual from one Member State to another for an act, such as rape or a drug offence, despite the fact that these acts may be criminalised throughout the Union. A risk or harm based assessment would not allow for this; the individual is a danger no matter where he or she may reside within the Union. Similarly, from a supranational perspective expulsion is also problematic; if the act is a wrong against the Union the exact location of the individual is of little relevance. ${ }^{86}$ The expulsion only makes sense by conceiving of the crime as an offense against the national community. ${ }^{87}$

However, these national values and the particular normative choices made by the Member States are increasingly framed by a supranational law. While there is no mention of Union law in cases dealing with the residence rights, in both Tsakouridis and in PI the Court does make reference to Union instruments that have been adopted in the areas of drug trafficking and the sexual exploitation of children. ${ }^{88}$ In a sense Union law and particular Union normative choices, are employed to validate the national choices made by Member States and to leave open the possibility of using those particular values and normative choices to clarify the duty of respect imposed on Union citizens. This is not quite the same thing as a Union value system, subsuming national determinations and replacing a national public policy with a Union public policy. It remains the national choice as reflected in national law, but there is a supranational presence in the field, not only in relation to controlling in a negative sense the discretion afforded Member States, but also in positively validating their choices, endorsing them on a Union level. The interaction between the national and supranational spheres in this area can be seen as a dialectic whereby national choices are reflected in Union instruments that in turn validate national choices, all the while leading to a greater convergence between individual, national communities while retaining those communities as distinct sites of self-determination and seen as autonomous moral entities

\footnotetext{
${ }^{86}$ For a discussion of the problem in the case of the ECrHR jurisprudence see P Van Dijk, 'Protection of "Integrated" Aliens against Expulsion under the European Convention on Human Rights' in Elspeth Guild and Paul Minderhoud (eds), Security of Residence and Expulsion: Protection of Aliens in Europe (Kluwer International 2001) 38.

${ }^{87}$ I would like to thank Dmitry Kochenov for forcing me to articulate this point during useful comments on an earlier presentation of this chapter in Florence.

${ }^{88}$ Tsakouridis (n 41) para 46. PI (n 42) paras 25-26. The latter category of crimes appears to be a particular interest of the Union and sits within an increasing role for Union law in children's rights and victims in general. See Eleanor Drywood and Helen Stalford, 'Coming of Age? Children's Rights in the European Union ' (2009) 46 CML Rev 143. It is worth noting also that the victims of MG's crimes were also her children.
} 
requiring respect. ${ }^{89}$ It does not involve the gradual disappearance of a distinct national ground of public policy and hence the rationale for the exception in the first place. ${ }^{90}$ In fact, once one accepts that the 'threat to public policy' is in fact a wrong committed against a distinct national community, there is no reason why Member States cannot share the same concept of public policy and the normative choices that go with it, and retain an ability to expel a Union citizen for a breach of the duty of respect, the target of the duty being as important as the content.

On its face this may seem as simply a negative duty to refrain from committing crimes. Nonetheless, one gets the impression from the Court's language in the expulsion and residence rights judgments that there is in fact a more positive, albeit rather inchoate, duty imposed on the citizen. It concerns the appropriate attitude the migrant citizen is expected to adopt vis-à-vis the host Member State. This approach of seeing integration as partially a process of adopting a particular attitude is echoed in another area of the Court's caselaw, in particular the imposition of integration requirements on third country nationals. ${ }^{91}$ To meet such requirements it is necessary that the individual in question 'make an effort' rather than meet some predefined linguistic or knowledge based standard. What is important is the attitude the individual adopts towards the host society, their willingness to integrate. As guests seeking membership of the community they are expected to reorientate their values in order to adopt the normative commitments of the host society. It is perhaps implicit and tacit but there is a positive requirement on the individual to at least demonstrate a certain attitude towards the host society. It is a deeper, thicker, normative and more social sense of integration. ${ }^{92}$ Such a conclusion is implicit in the relationship between crime and integration

\footnotetext{
${ }^{89}$ See Floris de Witte, 'Sex, Drugs and EU Law: The Recognition of Moral and Ethical Diversity in EU Law' (2013) 50 CML Rev 1545.

${ }^{90}$ Some authors and indeed the Commission have floated the notion of a convergence in national notions of public policy. See Kessedjian (n 82), Maria Castillo and Régis Chemain, 'La Réserve d'Ordre Public en Droit Communautaire' in Marie-Joëlle Redor (ed), L'odre public: Ordre public ou ordres publics Ordre public et droits fondamentaux (Bruylant 2001) $161 \mathrm{ff}$ and Commission (n 31) 10: 'Member States have discretionary powers for interpretation...[n] evertheless, the national concepts of public policy, public security and public health may gradually approach each other as European integration advances.'

${ }^{91}$ Case C-153/14 Minister van Buitenlandse Zaken v K and A EU:C:2015:453 para 56 in particular whereby under a proportionality analysis an individual who fails the test may nonetheless be granted a residence permit if he has demonstrated a 'willingness to pass the exam and have made every effort to achieve that objective.'

92 The parallels with integration requirements increasingly imposed on third country nationals (and permitted by Union law) as reflecting a more communitarian and integrationist (not to say assimilationist and exclusionary) approach towards migration cannot be ignored. See Rainer Bauböck and Christian Joppke, How Liberal are Citizenship Tests? (EUI Working Papers RSCAS 2010/41, 2010) and in the EU context Sergio Carrera (ed), 'The Nexus between Immigration, Integration and Citizenship in the EU' (Immigration, Integration and Citizenship, CEPS, Brussels, 25 January 2006).
} 
discussed, particularly in the AG Bot's Opinions in both PI and Onukwere and the judgment in Onukwere. The invocation of 'qualitative elements', drawing on the analogy of economic contributions from Dias, ${ }^{93}$ appears to set up a positive and active dimension in the integration process on the part of the Union citizen, apparently in opposition to the rather passive 'territorial and temporal' dimensions cited by the Court. ${ }^{94}$

\section{A Supranational Duty}

At the same time, this is a specifically European duty contained in Union citizenship and in particular Union citizenship as a status of integration. While the specific content of the duty is determined by reference to national criminal law and nationals are indeed subject to the same obligations, the nature of the duty and the consequences are different. For nationals it simply represents the duties co-citizens owe to each other in the context of a community of law, expressing particular moral choices, especially regarding appropriate mutual conduct. ${ }^{95}$ In addition to the general duty under national law, it also represents a qualitative dimension to the integration process that they are subject to qua Union citizens. It is intimately linked to the integration process that itself is an integral part of Union citizenship. It is a duty imposed by Union law and with consequences in Union law, namely the temporary loss of rights of Union citizenship, in addition to whatever consequences may flow from national law. Furthermore, the Union, by endorsing the expulsion of criminal citizens and validating Member State's normative choices in the area, can be said to be recognising the wrong done that national community and indirectly 'punishing' it through imposing consequences under Union law. It comes close to a supranational sharing of the national wrong, explored further in chapter 5 in the context of the European Arrest Warrant Framework Decision. ${ }^{96}$

What emerges from these cases is a duty of respect towards the values of the host society peculiar to Union citizenship reflecting both a re-balancing of the relationship of integration between the host-society and the individual, placing more emphasis on the role of the individual, and also a shift in the quality of that integration from an economic to a normative or indeed moral plane. Duties can be said to exist in Union citizenship, but operate at a

\footnotetext{
${ }^{93}$ Dias (n 69).

${ }^{94}$ Onuekwere (n 58) para 25.

${ }^{95}$ See Duff, Answering for Crime: Responsability and Liability in the Criminal Law (n 64) 49 ff.

96 Council Framework Decision 2002/584/JHA on the European arrest warrant and the surrender procedures between Member States [2002] OJ L 190/1.
} 
transnational level. Transnational obligations imposed by supranational law. It is through national criminal law that supranational duties are imposed on Union citizens and it is through transnational processes that common normative choices are affirmed at the level of the Union in a dialectic between national and supranational law. 


\section{An Area of Justice}

\section{Shared Enforcement and Shared Recognition of National Wrongs}

The second transnational dimension of Union citizenship has been termed autonomy. It might be useful to add the addendum 'in a single legal space'. For that is what is at stake in the concept of autonomy in the context of Union citizenship. On one level it is an exercise in quasi-mutual recognition, simply obliging Member States, through the use of the principle of free movement in particular, to recognise legal situations that arise in other Member States even where they differ from how those situations are regulated under their own legal regimes. The implication however is somewhat broader. As recognised by AG Sharpston, it enables individuals to passport legal situations throughout the Union; to enjoy a single legal status, composed of rights acquired under different national legal orders, throughout the Union. ${ }^{1}$ It generates a broader legal space, composed of different national legal orders, within which individuals can move. They do not remain tied to a particular national community but rather can travel throughout the territory of the Union. Their legal status is understood with reference to the wider Union as a whole.

Thus while primarily transnational in character it does generates a supranational reference point; the totality of the Member States' territory, that together form the Union territory. Indeed a link between this transnational aspect of Union citizenship and the supranational status constructed by the Court in Zambrano can be discerned. Though autonomy Union citizens can be said to occupy and share the 'territory of the Union as a whole', a phrase that is particularly prominent in the Court's judgment in Zambrano and in subsequent cases. ${ }^{2}$ Indeed, occupying this composite, plural legal space amounts in the Court's eyes to the

\footnotetext{
${ }^{1}$ Joint Opinion of AG Sharpston in Case C-456/12 $O \& B v$ Minister voor Immigratie, Integratie en Asiel EU:C:2014:135 and Case C-457/12 S v Minister voor Immigratie, Integratie en Asiel EU:C:2014:136 para 95.

${ }^{2}$ Case C-34/09 Gerardo Ruiz Zambrano v Office national de l'emploi (ONEm) EU:C:2011:124, [2011] ECR I1177, Case C-434/09 Shirley McCarthy v Secretary of State for the Home Department EU:C:2011:277, [2011] ECR I-3375, Case C-256/11 Murat Dereci and Others $v$ Bundesministerium für Inneres (Dereci) EU:C:2011:734, [2011] ECR I-11315, Case C-86/12 Alokpa et al v Minstre du Travail de l'Emploi et de l'Immigration EU:C:2013:645 and Case C-87/12 Ymeraga v Minstre du Travail, de l'Emploi et de l'Immigration EU:C:2013:291.
} 
'genuine enjoyment of the substance of the rights conferred by Union citizenship' that appears to lie at the heart of the Court's understanding of supranational citizenship. ${ }^{3}$

Just as citizenship can be said to operate in a broader space of movement, criminal law has also been the subject of various efforts to create a single legal space. If anything the effort as creating a single 'area of justice' is even more explicit in the area of criminal law. Through the use of mutual recognition, a technique developed in the internal market and since exported (with various criticisms) ${ }^{4}$ to the 'Area of Freedom, Security and Justice', 5 the Union has attempted to ensure that crime, or more precisely, criminal enforcement, too operates with reference to the territory of the Union as a whole.

Two complementary aspects of this 'area of justice' are analysed in the following two chapters; the transnational enforcement of criminal law, in particular the operation of the European Arrest Warrant Framework Decision (EAW FD) ${ }^{6}$ and the recognition of final judgments, most notably the operation of Article 54 of the Convention Implementing the Schengen Agreement (CISA). ${ }^{7}$ Combined they are designed to create a single area of justice for the enforcement and recognition of crime within the Union. While the construction of the Area of Justice involves a far larger suite of mutual recognition instruments, ${ }^{8}$ this thesis concentrates on these two as the most prominent examples that have been analysed by both judicial and academic writing, ${ }^{9}$ those that are most closely connected with the free movement of persons ${ }^{10}$ and finally as two complementary instruments; both are designed to

\footnotetext{
${ }^{3}$ Zambrano (n 2) para 42.

${ }^{4}$ See in particular Steve Peers, 'Mutual Recognition and Crimial Law in the European Union: Has the Council got it wrong?' (2004) 41 CML Rev 5 and Markus Möstl, 'Preconditions and Limits of Mutual Recognition' (2010) 47 CML Rev 405.

5 Particularly since the Hague Programme (The Hague Programme: Strengthening Freedom, Security and Justice in the European Union [2005] OJ C 53/1). The prominence of mutual recognition as a technique for integration has since been formalized in the Treaty of Lisbon in art 82(1) TFEU.

${ }^{6}$ Framework Decision 2002/584/JHA on the European arrest warrant and the surrender procedures between Member States (EAW FD) [2002] OJ L 190/1.

${ }^{7}$ Convention on the Implementation of the Schengen Agreement, Ch 3.

${ }^{8}$ See Steve Peers, EU Justice and Home Affairs Law (3 edn, OUP 2011) ch 9.

${ }^{9}$ Indeed the EAW FD has been described as the Union's flagship instrument in this area and has been used as a template for other mutual recognition instruments in particular other warrants such as the European Evidence Warrant (Framework Decision 2008/978/JHA on the European Evidence Warrant for the pupose of obtaining objects, documents and data for use in proceedings in criminal matters [2008] OJ L 350/72) and its replacement the European Investigation Order (Directive 2014/41/EU regarding the European Investigation Order in criminal matters [2014] OJ L 130/1). For the use of the structure and techniques (especially the abolition of the double criminality requirement) in other mutual recognition instruments see Peers, EU Justice and Home Affairs Law (n 8) $\operatorname{ch} 9$.

${ }^{10}$ Other instruments are undoubtedly frequently related to crime committed by individuals in circulation within the Union but not necessarily whereas the EAW FD and Article 54 CISA directly relate to the situation of an
} 
ensure that an individual is called to account (and if necessary punished) for wrongs committed at least once within the Union, but only once. ${ }^{11}$ They are two sides of the same coin of an area of justice; justice for the community in ensuring that an individual is punished; justice for the individual in ensuring that that punishment only takes place once.

The construction of this Area of Justice reinforces and complements Union citizenship. On the one hand, the free movement rights of Union citizens are directly reinforced by the existence of Article 54 CISA, a provision that is designed explicitly to maximise the opportunities of individuals to move throughout the Union. Indeed, this objective has been the main consideration to inform the interpretation of that provision by the Court of Justice. On the other hand, the EAW FD is a complement to Union citizenship. It is a shared enforcement mechanism for national criminal law and criminal judgments, that complements the free movement of responsibilities incurred under national criminal law with the free movement of rights associated with Union citizenship. A combination of these two instruments ensures that an individual's status under criminal law, just as under civil law, is carried throughout the Union. Just as citizenship, crime is understood with reference to a broader legal space.

This shared space is however a composite legal space, composed of the various Member States and the national communities they represent. It is national criminal law and national judgments that travel throughout the Union. It is similarly clear that it is against the individual Member State that the individual is deemed to have offended, who judges that individual and to which he or she must return to be judged in the case of the EAW FD.

However, just as with the development of 'autonomy' within Union citizenship, the development of the single area of justice gives rise, in an even more explicit fashion to broader supranational phenomena that focus around the idea of a shared space. ${ }^{12}$ In the Area

individual who has moved to another Member State either before (in the case of the EAW) or after (in the case of Article 54 CISA) their prosecution and conviction/acquittal.

${ }^{11}$ For a particularly strong presentation of the complemtarity of the EAW FD and Article 54 CISA see Robin Lööf, 'Defending Liberty and Structural Integrity: A social contractual analysis of criminal justice in the EU' (PhD thesis, Department of Law, European University Institute 2008).

${ }^{12}$ Starting from the very assertion of a single 'Area of Freedom, Security and Justice'. For a discussion of the representative and symbolic function of such a construction see Patrick Twomey, 'Construcuting a Secure Space: The Area of Freedom, Security and Justice' in David O'Keefe and Patrick Twomey (eds), Legal Issues of the Amsterdam Treaty (Hart 1999) and, in another sense, Hans Lindahl, 'Finding a place for freedom, security and justice: the European Union's claim to territorial unity' (2004) 29 EL Rev 461. 
of Justice this shared space has been overlain with normative content that has arisen directly from transnational processes. Certain common rights have developed for use in transnational enforcement, a common citizenship justifies it and common understandings of wrongful conduct, ie crimes, are also assumed by the EAW FD in particular. But the supranational phenomenon goes further; by participating in a system of shared enforcement and by creating a system of shared recognition of national calling to account, Union law has implicitly assumed a shared supranational community.

In light of the national and transnational dimensions, it is argued here that that shared community is best understood as a composite community, whereby the wrong experienced by one Member State is shared by all and that the calling to account before one Member State counts as being called to account before all Member States. Crime, wrongful conduct and calling to account are experienced at a supranational level but through national communities. 


\title{
Chapter 5
}

\section{An Area of Justice I:}

\section{The European Arrest Warrant:}

\section{Transnational Enforcement in a Supranational Space}

\author{
Introduction: \\ Transnational Enforcement
}

Criminal law has long been considered one of the prerogatives of the sovereign state and is intimately to the concept of territorial control and the legitimate use of force. ${ }^{1}$ This nexus between the legitimate use of force, territory and control - lies at the heart of the modern Weberian concept of the state and is one of the fundamental aspects of statehood that is being challenged by the development of the former third pillar and now Title $\mathrm{V}$ of the TFEU. A particular lighting-rod for attention and no little criticism has been the 'flagship' instrument of mutual recognition in criminal law matters; the European Arrest Warrant Framework Decision (EAW FD). ${ }^{2}$ It has been accused of prejudicing the rights of individuals ${ }^{3}$ and being based on a false analogy with the free movement of goods. ${ }^{4}$ The use of mutual recognition - a governance technique developed in the internal market for the free movement of goods - in the area of freedom, security and justice and especially in the area of judicial decisions in criminal matters has been viewed as generating instances of extraterritoriality in the area of criminal law and the use of force, a development that threatens

\footnotetext{
${ }^{1}$ See Christian Kaunert, 'The Area of Freedom, Security and Justice: The Construction of a 'European Public Order' (2005) 14 European Security 459 and Maria Fletcher, Robin Lööf and Bill Gilmore, EU Criminal Law and Justice (Edward Elgar 2008) 5-6.

${ }^{2}$ Framework Decision 2002/584/JHA on the European arrest warrant and the surrender procedures between Member States (EAW FD) [2002] OJ L 190/1.

${ }^{3}$ Markus Möstl, 'Preconditions and Limits of Mutual Recognition' (2010) 47 CML Rev 405.

${ }^{4}$ Steve Peers, 'Mutual Recognition and Crimial Law in the European Union: Has the Council got it wrong?' (2004) 41 CML Rev 5. Although see the response of Janssens who highlights the complexity and variability of mutual recognition instruments within the EU legal order. See Christine Janssens, The Principle of Mutual Recognition in EU Law (OUP 2013) Conclusion.
} 
territorial integrity and the sovereignty of Member States, the principle of legality and the fundamental rights of individuals. It has been subject to a number of challenges and resistances by national constitutional courts. ${ }^{5}$ Overall, it has been said to challenge the traditional nexus between citizenship, territory, sovereignty and criminal law. ${ }^{6}$

It does challenge this traditional nexus, however not in a manner one might immediately assume. It is wrong to assume that there is a simple extension of territorial jurisdiction beyond the state, ${ }^{7}$ allowing a Member State to exercise jurisdiction outside its own territory, imposing its law in the territory of other Member States, and hence raising problems of legality in particular. The territorial jurisdiction exercised by states in their criminal law is a part of criminal law that is defined for the most part by national law. ${ }^{8}$ This is generally defined in accordance with the territory of the state but there are circumstances when the state seeks to exercise extra-territorial jurisdiction, largely based on personal jurisdiction. ${ }^{9}$ Member States already claim extra-territorial jurisdiction in criminal law and the EAW FD does not change this in any way. It is certainly true that there is increasing change in traditional notions of territoriality in the context of national criminal law, linked to interrelated social, economic and technological developments ${ }^{10}$ and that the EAW FD is an element in the response to the globalisation of crime. However, the EAW FD does not, in and of itself, alter national territorial jurisdiction.

\footnotetext{
${ }^{5}$ See Jan Komarek, 'European Constitutionalism and the European Arrest Warrant: In Search of the Limits of "Contrapunctual Principles"' (2007) 44 CML Rev 9 and Valsamis Mitsilegas, 'The Constitutional Implications of Mutual Recognition in Criminal Matters in the EU' (2006) 43 CML Rev 1277.

${ }^{6}$ Valsamis Mitsilegas, EU Criminal Law (Hart 2009) Conclusion.

7 This view of mutual recognition may be considered implicit in Kalypso Nicolaidis and Gregory Shaffer, 'Transnational Mutual Recognition Regimes: Governance without Global Government' (2005) 68 LCP 263.

${ }^{8}$ Some EU criminal law instruments that deal with substantive criminal law do oblige member states to exercise extra-territorial jurisdiction in certain circumstances see Framework Decision on combating terrorism [2002] OJ L 164/3 art 9(1) and Directive 2011/93/EU on combating the sexual abuse and sexual exploitation of children and child pornography, and replacing Council Framework Decision 2004/68/JHA [2011] OJ L 355/1 art 17.

${ }^{9}$ The French Criminal code in particular exercises so called passive extra-territorial personal jurisdiction for serious crimes such as murder, meaning it claims authority to punish individuals for crimes committed against French citizens abroad. Irish law on the other hand exercised active extra-territorial jurisdiction, meaning it will prosecute Irish citizens for crimes committed outside the territory of the Republic of Ireland. The discrepancy between jurisdiction proved useful to the Irish Supreme Court when deciding not to surrender a British national sought in France for a crime committed in Ireland, with the Supreme Court requiring reciprocity between both the category of the crime (murder) and the precise form of jurisdiction; Ireland only exercised active extraterritorial jurisdiction (where the suspect is a national) whereas France was exercising passive extraterritorial jurisdiction (where the victim is a national). See Minister for Justice, Equality and Law Reform v Bailey [2012] IESC 16.

${ }^{10}$ See Lindsay Farmer, 'Time and Space in Criminal Law' (2010) 13 New Crim L Rev 333.
} 
Indeed, the European Arrest Warrant Framework Decision is at pains to ensure that Member States retain priority regarding over the prosecution of crimes committed on their territory. Article 7(a) EAW FD provides that a European Arrest Warrant (EAW) can be refused in cases where the crime took place principally in the territory of the executing Member State. ${ }^{11}$ A requirement of reciprocity may also be imposed, allowing Member States to refuse to surrender where they do not themselves exercise extra-territorial jurisdiction in similar cases. ${ }^{12}$ Similar provisions are found in other mutual recognition instruments such as the European Evidence Warrant $(\mathrm{EEW}){ }^{13}$ The question of extra-territorial jurisdiction is a sensitive one and treated as such by the EAW FD. Member States are quite simply not obliged under the mutual recognition instruments to accept the jurisdiction of other Member States over acts committed on their territory. While not denying the existence of extraterritorial forms of jurisdiction it nonetheless prioritises the claims of the Member State on whose territory a particular criminal act took place.

However, while EU mutual recognition instruments do not change the territorial jurisdiction of Member States' criminal law, there is a truth in the idea that traditional concepts of territoriality and sovereignty are disrupted and that this development has had implications for the legitimacy of the EAW system. The mutual recognition instruments do imply a certain loss of control. But that loss of control is not over territorial jurisdiction per se; it does not imply that Member States are obliged to accept the jurisdiction of other Member States over their territory. What it does imply is a loss of control over how individuals on their territory are treated and the extent to which they are subject to the criminal justice system of other Member States. It is not extra-territorial jurisdiction that is at stake - indeed there are express provisions to prevent this occurring - but extra-territorial enforcement. The EAW FD creates a single area of enforcement for national criminal law under which Member States are obliged to participate in the enforcement of other Member State's criminal law on their own territory. The result is that criminal enforcement now takes place

\footnotetext{
${ }^{11}$ EAW Framework Decision (n 2) art 7(a).

${ }^{12}$ Ibid art 7(b). Exactly how narrowly the concept of type of extra-territorial jurisdiction is defined can lead to some surprising results. See Bailey (Supreme Court) (n 9).

${ }^{13}$ Framework Decision 2008/978/JHA on the European Evidence Warrant for the pupose of obtaining objects, documents and data for use in proceedings in criminal matters [2008] OJ L 350/72 art 13(f). Since superseded by Directive 2014/41/EU regarding the European Investigation Order in criminal matters [2014] OJ L 130/1 (deadline for transposition 22 May 2017). Similar safeguards regarding jurisdiction are contained in its article 11(e).
} 
with reference to the combined territories of the Member States, with reference to the Union as a whole.

However, in being obliged to enforce other Member State's criminal law on their territory, Member States' traditional controls over how the principles of legality and of fundamental rights are applied on their territory are undermined. The controls that normally ensure the legitimacy of the use of force on a particular territory are compromised; the transnational system of enforcement detaches legitimacy from territory. This is the real question raised by the EAW FD - how a system of transnational enforcement generating a single area of enforcement with multiple legal orders can function in a legitimate fashion when legitimacy is traditionally ensured by a national legal order imposing its particular controls on a particular territory.

The answer lies in the supranational dimension to the area of justice. From a national perspective the EAW FD system does indeed raise serious questions regarding the sovereignty of states and the legitimate use of force. However, the legitimacy that is disrupted at a transnational level is reasserted at a supranational level though the development of common rights and norms regarding wrongful conduct. Moreover, Union citizenship, as a shared status that relates to precisely this single area of movement, also plays a role in ensuring the legitimacy of the EAW system. In doing so, it can even be said to imply a Union-wide community at a supranational level.

\section{Legitimising Punishment: Three Requirements}

The EAW FD challenges the legitimacy of criminal law enforcement in three ways in particular. The legitimacy of a particular community holding an individual to account and potentially punishing him for wrongdoing depends on identifying a particular moral standing of that community vis-à-vis that individual. ${ }^{14}$ For Duff this moral standing is assured through the status of citizenship and the link this creates between the individual and broader political community. ${ }^{15}$ This relationship of citizenship (or 'guests' for non-citizens) ${ }^{16}$ is a necessary

\footnotetext{
${ }^{14}$ See Alejandro Chehtman, 'Citizenshp v Territory: Explaining the Scope of the Criminal Law' (2010) 13 New Crim L Rev 427.

${ }^{15}$ RA Duff, Answering for Crime: Responsability and Liability in the Criminal Law (Hart 2007) ch 2.

${ }^{16}$ Ibid 54. Perhaps the most problematic aspect of Duff's theory see Chehtman (n 14). In particular it has problems explaining not just the liability of non-nationals on the territory of the state but also certain forms of
} 
but not a sufficient condition for the legitimacy of that community's actions in punishing an individual. Additionally, the wrong must be a public one - one that is of concern to the public. In other words it must be considered criminal by the community. ${ }^{17}$ Finally, the community must ensure that by affording certain rights and complying with certain standards of procedural justice it does not forfeit its right to call individuals to account and potentially punish them; it owes basic duties in its conduct towards others in order not to undermine its own moral standing and hence legitimacy. ${ }^{18}$

All three elements are challenged by the operation of the EAW system. Firstly, the EAW obliges Member States to recognise the authority of other Member States to punish their nationals. Secondly, the EAW has (partly) abolished the rule against double criminality. The purpose of the double criminality rule was to ensure that states, when participating in the enforcement of criminal law, would only cooperate in instances where they too considered the act to be a crime or a public wrong. Thirdly and finally, the EAW system prevents Member States from imposing any fundamental rights control on the process of surrender.

It is true that from a national and transnational perspective the legitimacy of the EAW system is worrying. ${ }^{19}$ However, those elements of legitimacy that are disrupted at a national level - citizenship, legality and fundamental rights - are present in the operation of the EAW system, but at a supranational level. It is this supranational perspective that is essential to understand the legitimacy of the EAW and its implications on citizenship and on the structure of the Union's political community. Citizenship, legality and fundamental rights, separated from national territory are relocated within a supranational space. It is in response to a process of transnational enforcement of national law that supranational values and ultimately a supranational community emerges.

\section{Legitimising Shared Enforcement I Shared Citizenship}

\footnotetext{
extra-territorial jurisdiction such as the passive extraterritorial jurisdiction exercised by France in Bailey (Supreme Court) (n 9).

${ }^{17}$ Duff (n 15) 49-50.

18 Ibid 181-191.

${ }^{19}$ See responses by Courts such as Re Constitutionality of German Law Implementing the Framework Decision on a European Arrest Warrant [2006] 1 CMLR 16 and Attorney General of the Republic of Cyprus $v$ Konstantinou [2007] 3 CMLR 42 and of scholars such as Peers (n 4) and Möstl (n 3).
} 


\section{Abolition of the Nationality Exemption}

Perhaps the most judicially contested aspect of the EAW system was the abolition of the nationality exemption. The nationality exemption was typically applied by states within the civil law tradition to shield their nationals from extradition to other States. Its justifications are many and varied and include a special relationship between the citizen and 'his' homeland, a general distrust of foreign jurisdictions, perceived biases against 'foreigners', a need to be judged by ones 'natural peers' or simply the practical difficulties that an individual might face in navigating a foreign legal system, often in a language he or she does not understand. ${ }^{20}$ It does not necessarily imply that the state does not believe the individual should be punished for wrongful behaviour. Indeed, states frequently undertook to 'surrender or prosecute' in the context of extradition clauses if they exercised a nationality exception and the exercise of personal extra-territorial jurisdiction by these states facilitated such an obligation. ${ }^{21}$ Within Duff's theory it can perhaps be understood as a claim by the state of nationality that it is the most appropriate entity to try and punish a particular individual.

As described in chapter 3 in more detail, the nationality exemption was not carried forward within the European Arrest Warrant system. Instead it was replaced by a modified principle allowing Member States to refuse surrender or impose a guarantee that an individual, be it a national or resident, can serve their sentence in the executing Member State. ${ }^{22}$ However, importantly, the individual remains subject to the issuing Member State's law and is still called to account before that Member State, the only difference being that the sentence is carried out closer to home. The calling to account in the form of a trial still takes place before the issuing Member State; it is the punishment that is carried out by the executing Member State. ${ }^{23}$ Secondly, and as explored further in chapter 4 , the entire rationale and logic of the new article is based not on nationality but rather on the principle of social integration and the social links an individual may have with the executing Member State. ${ }^{24}$

\footnotetext{
${ }^{20}$ See generally Michael Plachta, '(Non-)Extradition of Nationals: A Neverending Story' (1999) 13 Emory Int'l L Rev 70.

${ }^{21}$ See Michael Plachta, 'European Arrest Warrant: Revolution in Extradition?' (2003) 11 Eur J Crime Crim L \& Crim Just 178.

${ }^{22}$ See EAW Framework Decision (n 2) arts 4(6) and 5(3).

23 A not unimportant feature giving rise to a certain shared responsibility for Member States for both the punishment and rehabilitation of individuals. See further chapter 3.

${ }^{24}$ See further chapter 3.
} 
The abolition of this exemption was subject to a significant degree of resistance from national constitutional courts. The German, Polish, Czech and Cypriot constitutional courts were all seized with constitutional challenges to the national implementing legislation, with all but the Czech Court finding it in breach of national constitutional provisions preventing a national from being extradited. Characteristically, it was the German Constitutional Court (Bundesverfassungsgericht or BvfG) that provided the most trenchant criticism for the Framework Decision and in doing so emphasised the special bond between the citizen and the state reflected in the prohibition on extradition. In its decision the BvfG highlighted the link between the nationality exception, the sovereign community and the individual. To be excluded from the state and subject to foreign laws was tantamount to an abrogation of the protection offered by the legal system of the state to a citizen when present on its territory. Indeed, such a procedure was equated to denationalisation or stripping an individual of rights inherent in citizenship and an analogy was drawn with the treatment of the Jewish community under National Socialism. ${ }^{25}$ Despite its perhaps (melo)dramatic rhetoric the BvfG in its remedy showed itself more concerned with territorial effect of the EAW and the risk of foreign law being applied on German territory. ${ }^{26}$ It therefore ordered the German Government to implement the territorial exception in order to render the implementing legislation constitutional.

\section{Union Citizenship and a Single Area of Justice}

The result of the creation of a system of shared enforcement is an altered relationship between the individual and both the executing and issuing Member States. The executing Member State must recognise the legitimate claims of other Member States over individuals located on its territory. The result is a certain weakening of the relationship between the executing Member State and its citizens. Conversely, the relationship between the issuing Member State and the community it represents (and potentially all Member States in the Union) and the individual is also affected. Any individual may now be called to account

\footnotetext{
${ }^{25}$ Re Constitutionality of German Law Implementing the Framework Decision on a European Arrest Warrant (n 19) paras 66-67.

${ }^{26}$ See in particular paragraphs 85-86: 'There is a relevant connection to Germany when a significant proportion of the places where conduct or its effects have occurred lie in German territory. In this situation the responsibility of the State to avoid damage to its legal system, and the fundamental rights claims of the person against whom the arrest warrant is issued, coincide in such a way that usually there is an obstacle to extradition...the assessment is otherwise if the crime of which the person in question is accused has a decisive foreign connection. A person who does something under a foreign legal system must reckon with the possibility that he will be taken there to answer for it.'
} 
anywhere in the Union for an offense committed against that Member State. These national responsibilities attach to an individual and may be enforced within a wider geographical area. Just as rights attach to individuals and are transported or passported throughout the Union, responsibilities are similarly placed in a broader space of movement and are enforceable anywhere in the Union.

There is a certain correspondence between the transnational rights associated with free movement and the transnational responsibilities, which is rooted in the status of Union citizenship. Both rights and responsibilities operate in a similar fashion of mutual recognition and both are justified by a similar membership structure based on transnational movement and multiple, potential membership in a plural set of communities that together form a broader space of movement. Just as autonomy and choice lie at the heart of mutual recognition of rights associated with free movement, that same freedom and choice can be seen as legitimising responsibilities incurred in other Member States through a process of consent. ${ }^{27}$ Individuals are given the opportunity to move to other Member States and there enjoy certain rights as part of a broader status and in doing so subject themselves to responsibilities.

In opposition to the BvfG, this view of Union citizenship and the correlation between with free movement and responsibilities, has been noted by the Czech Constitutional Court. For the BvfG Union citizenship is a status that merely supplements national citizenship with a set of extra rights, and does not change it in any fundamental way. It is simply an extension, a set of rights added on without affecting the nature of national citizenship itself and without changing the relationship with the state of nationality and the guarantees that go with it and in particular does not justify the setting aside of the traditional protection from extradition contained in the German Basic Law. ${ }^{28}$ The Czech Constitutional Court on the other hand took a more organic view of the relationship between Union citizenship and national citizenship. Not only is Union citizenship a set of additional rights - an extension of national

\footnotetext{
${ }^{27}$ Richard Bellamy, 'A Duty-Free Europe? What's Wrong with Kochenov's Account of EU Citizenship Rights' (2015) 21 ELJ 558, 564-6. Bellamy is not speaking specifically of responsibilities incurred through criminal law (in Duff's terms the responsibility to answer for wrongdoing) but rather civic responsibilities in the abstract. Nonetheless there is no reason such a reasoning cannot be applied in the current case. There are of course classic problems associated with legitimacy through consent and the contract tradition from which it emerges, a discussion of which is outside the scope of this thesis. See Dudley Knowles, Political Obligation: A Critical Introduction (Routledge 2010) chs 7-8.

${ }^{28}$ Re Constitutionality of German Law Implementing the Framework Decision on a European Arrest Warrant (n 19) paras 74-75.
} 
citizenship rights - but it alters and changes certain aspects of national citizenship, in particular by recognising responsibilities to other Member States. The link between free movement, Union citizenship and responsibilities is recognised by the Czech Constitutional Court for whom Union citizenship introduces '[a] qualitatively new situation...Citizens of the Member States enjoyed, in addition to rights arising from citizenship in their own State, also rights arising from EU citizenship, which guaranteed, among other things, free movement within the province of the entire Union....If Czech citizens enjoyed certain advantages connected to the status of EU citizenship, then they had also to accept a certain degree of responsibility. ${ }^{29}$

It is important to note that in the Czech Constitutional Court's judgment it is not the rights per se that ground the responsibility in a form of quid pro quo but the status of citizenship and the broader transnational membership relationship that is established by virtue of Union citizenship. While rights and responsibilities form the content of the membership status, there is no implication that an individual must have exercised or indeed be capable of exercising rights in order to hold responsibilities. It is the status rather than the enjoyment of specific rights that is important and that legitimises the imposition of responsibilities. Union citizens stand in a particular form of moral and political relationship to other Member States of the Union; a relationship that for the Czech Constitutional Court legitimises their being directly subject to the criminal law of those states and justifies the removal of protections that states typically offered individuals that fell within their jurisdiction. ${ }^{30}$ Union citizenship is an integral part of national citizenship and changes the meaning of national citizenship. By virtue of being Czech one must also accept responsibilities towards France, Estonia etc. This is why the exercise of some form of special protection vis-à-vis other states in the Union is no longer justified.

This link with the status of citizenship is important in Duff's account for founding authority to punish and goes some way towards legitimising the more controversial aspects of the EAW FD. In order for a particular body to have the right to punish an individual it must have

\footnotetext{
${ }^{29}$ Re Constitutionality of Framework Decision on a European Arrest Warrant (Czech Constitutional Court) [2007] 3 CMLR 24 para H6.

${ }^{30}$ Although it should be noted that the comment is largely academic; the Czech Constitutional Court did not find that the Czech Constitution prevented nationals from being surrendered in any case, the right to a homeland being largely a prohibition against forced exile such as occurred during the 'demolition' under the communist regime. See ibid para 41.
} 
a particular the moral standing vis-à-vis that individual. ${ }^{31}$ That moral standing is based on a relationship of belonging to a particular community that generates a network of interactions and ties, and ultimately rights and responsibilities. Due to the special bonds formed by Union citizenship, Member States have the requisite moral standing in order to legitimately call individuals to account regardless of where they are located within the Union. And importantly, other Member States may not intervene to prevent that occurring. Just as Member States must respect the rights granted by other Member States, they must respect the responsibilities owed those Member States and the right of other Member States to enforce those responsibilities.

There is however a different structure in the enforcement of these responsibilities compared to rights acquired under Union law that emphasises the enduring national character of the wrong committed by an individual. The individual citizen typically acquires rights in a particular Member State, moves to another Member State and it is that, second, Member State that is under an obligation to enforce or respect those rights. The rights acquire a freefloating character. Thus an individual may move to Ireland, there be joined by his or her family members and subsequently move to France. France under those circumstances is obliged to recognise the right to family unification in these circumstances and take appropriate measures, such as the issuing of residence permits. Under the EAW system and the system of the free movement of responsibilities there is an additional stage involved, returning the individual to the original Member State, thereby rendering the process more circular. The responsibility is owed to the first Member State and remains owed to the first Member State, the obligation placed on the second Member State is merely transitory; to detain and surrender an individual and return him or her to the original Member State. Unlike rights, responsibilities created under national criminal law remain clearly linked to a particular Member State. Not only are they created under a particular Member State's national law but they are owed, and remain owed to that particular Member State; they do not detach from a particular community and float throughout the territory of the Union in the same manner as rights.

Responsibilities therefore play out in a broader space, which shifts between supranational, or Union-wide, and national. Union citizens occupy a broader space of movement in which a

\footnotetext{
${ }^{31}$ See Duff (n 15) ch 8.
} 
political status involving rights and responsibilities is established with a number of separate national communities. It is a single space of movement within which national responsibilities are enforced. The image of a single area of justice is not simply rhetorical but refers to a very real space with reference to which Union citizenship operates including both rights and responsibilities. And it is on this single, supranational space that the issues of legality and rights, detached from national territory re-emerge.

\section{Legitimising Shared Enforcement II Shared Wrongs}

This moral standing between the issuing Member State and the individual established through Union citizenship explains to some extent the obligation placed on the executing Member State to participate in a system of shared enforcement. However, it is not sufficient. For Duff, the justification for punishment emerges not just from the status of citizenship but also from the determination of conduct as publically wrongful in the eyes of the community. It must be a wrong that concerns the public and moreover it must concern that particular public or community. ${ }^{32}$ Thus, while the wrongs we are concerned with in the system of shared enforcement remain fundamentally (trans)national that is not to say that there is not a certain shared dimension to them, both in conception and experience, that justifies shared enforcement and implies a broader supranational community.

\section{Abolition of Double Criminality}

Perhaps the most controversial aspect of the European Arrest Warrant Framework Decision was the abolition of the double criminality rule. The EAW FD in principle abolishes the rule of double criminality, it may be reintroduced by Member States as an optional ground for refusal but this exception will not apply to a set list of thirty two categories of core crimes, such as murder, rape and theft and certain cross-border crimes subject to the Union's approximation competence under Article 83(2) TFEU. ${ }^{33}$ It therefore abolishes a strict rule of double criminality for potentially all crimes, and certainly for a list of thirty-two categories of core crimes. Furthermore, the criminal nature and classification of the act is determined

\footnotetext{
${ }^{32}$ Ibid 49. It is this concern to a particular community that underpins Duff's explanation of jurisdiction.

${ }^{33}$ EAW Framework Decision (n 2) art 2(1) and (2).
} 
by the requesting Member State, a determination that must be accepted by the Member State of execution.

The rule of double criminality has frequently been described as a specific application of the general principle of legality in criminal law, that an act should not be punishable unless it is forbidden by sufficiently clear and validly adopted law or more specifically the principle of nullum poena sine lege (no punishment without law), the argument being that to arrest and detain an individual in a particular state for an act that that state does not in fact consider criminal, would amount to an illegal deprivation of liberty in the absence of a crime and a violation of his or her right to liberty. It has therefore been linked to both general legal principles and the fundamental rights of individuals. In this view legality is strictly tied to territoriality; in order for any steps in enforcement to take place the act must be considered a crime by the legal order that operates on that particular territory.

The EAW FD does not abolish the principle of legality but rather separates it from strict considerations of territory. The crime the specific act for which the accused individual is being sought, is a crime as defined by law. Indeed, it is defined as such by the most appropriate law, that where the act was committed or by the community whose interests were adversely affected. Crimes as wrongs are relational acts and take place with reference to a particular community; it is by reference to the law of that community that the legality or otherwise of the crime should be assessed. ${ }^{34}$ This is precisely the position that has been adopted by the Court of Justice. In Advocaten voor de Wereld the plaintiffs, a Belgian NGO, raised a complaint based on the violation of fundamental rights, including the principle of legality. ${ }^{35}$ The Court in its answer pointed out that the European Arrest Warrant Framework Decision does not classify an act as criminal or otherwise; that is for the national law of the issuing Member State. The EAW FD is merely an instrument of mutual recognition of a national act. The act is therefore validly classified as a crime under the appropriate national law, in this case the law of the requesting Member State. ${ }^{36}$ It replaces national legality with a form of transnational legality.

\footnotetext{
${ }^{34}$ Indeed the question not only of whether the state has a right to punish but equally important which state has the right to punish is one that has largely been ignored by criminal law theory see Chehtman (n 14).

${ }^{35}$ Case C-303/05 Advocaten voor de Wereld VZW v Leden van de Ministerraad EU:C:2007:261, [2007] ECR I3633.

${ }^{36}$ Ibid paras 52-54.
} 
What is really at stake is the participation of the executing Member State in the enforcement of another Member State's criminal law and how it reconciles this with its particular normative choices regarding what acts should be classified as criminal. Through the rule of double criminality the requested state insists that any use of force on its territory complies with its own understanding of what acts should attract criminal liability. For Peers '[s]ince sovereign States are free to take different views as to what should be criminalized and to what extent, and these differences are rooted deeply in different cultures and national identities and represent different choices resulting from the democratic process in each State, why should States in principle be obliged to assist another State to apply its criminal law where the two States differ on whether the relevant act should be criminalized? ${ }^{37}$ What is at stake is the extent to which a Member State can be obliged to enforce on its territory the normative choices made by another Member State.

\section{Shared Conception of a Wrong}

However, in truth the EAW FD does not entirely abolish the double criminality rule; it establishes a presumption that it would be met in all relevant cases. The implication is that there is a shared conception of the wrongful character of certain actions throughout the Union. It will be recalled that the requirement of double criminality is abolished definitively for a list of 32 categories of crimes. This list is not random. The Court of Justice has claimed that the 'serious' character of these crimes justifies their placement on the list. ${ }^{38}$ That may be somewhat misleading. There is a relationship with 'seriousness', as indicated by the de minimis rule contained in art 1(3) EAW FD limiting the use of the EAW FD to offences that carry a certain minimum sentence. ${ }^{39}$ However, the 'seriousness' here is a label for their centrality to a common understanding of the core elements of a criminal justice system

\footnotetext{
${ }^{37}$ Peers (n 4) 24-25. Indeed, originally the double criminality rule was an expression of the rule of reciprocity in relation to criminal norms and only later came to be considered as an individual right. See Lech Gardocki, 'Double Criminality in Extradition Law' (1993) 27 Israel L Rev 288, 289

${ }^{38}$ Advocaten voor de Wereld (n 35) para 57.

${ }^{39}$ The question of proportionality has also been used by some national courts as a reason to refuse surrender, considering detention and surrender for a minor offence would be a disproportionate interference with a suspects rights (particularly if a family life is involved) see Minister for Justice and Equality v Jaroslaw Ostrowski [2012] IEHC 57. Although note this ruling was reversed on appeal to the Irish Supreme Court. The Commission for its part does believe proportionality should play some role in the EAW system but is a matter to be assessed by the issuing Member State; the role of the executing Member State remains a formal one. See European Commission, Report from the Commission on the implementation since 2007 of the Council Framework Decision of 13 June 2002 on the European arrest warrant and the surrender procedures between Member States (COM(2011) 175 final, 2011) 7-8.
} 
rather than any heightened level of harm or other moral transgression. After all minor thefts that may fall within the scope of the EAW FD can hardly be considered 'serious' in terms of harm caused or inherent moral blameworthiness. Rather it is the centrality to a system of criminal law that protects the person and property that marks it as serious. These are acts against the person and against property that form the core of any system of criminal law concerned with protecting the liberty and interests of individuals. Indeed, they would generally be seen as falling within the category of mala in se - acts whose wrongful character arises independent of legal regulation and form the basis of a shared common denominator regarding acts that should be criminal.

It might be argued that some of the areas of crime contained in article 2(2) EAW FD do not fall into the category of mala in se or classic crimes against the person or property such as corruption, counterfeiting and computer related crime. Yet again there is an assumption that all Member States share the wrongful conception of these crimes, not through some shared heritage of the criminal law, but this time through a shared understanding expressed through both primary and secondary Union law. These crimes tend to be precisely those for which the Union has competence to enact approximation measures and which have a cross-border dimension. ${ }^{40}$ The presumption is that by regulating such matters at a Union level a certain equivalence is assured. The double criminality rule is not disapplied; it is simply presumed to have been met through a shared supranational framework.

It is therefore the shared judgement of their wrongful character and the appropriateness of their criminalisation amongst Member States that justifies the abolition of a formal condition of double criminal in these instances. The abolition of the double criminality rule does not mean that it is no longer necessary for these acts to be classified as criminal in all Member States. On the contrary, it is precisely because these acts are considered criminal by all Member States - either through their historical centrality to a criminal justice system or through approximation measures at a Union level - that there is no need to apply a rule of double criminality. These are acts that in the view of all Member States are wrongful and properly concern the public. This is precisely the understanding of AG Ruiz-Jarabo in Advocaten voor de Wereld when dismissing the requirement of double criminality. Such a

\footnotetext{
${ }^{40}$ For the link between the approximation competence contained in Article 83(2) TFEU and double criminality see ch 7. See also Anne Weyembergh, 'The Functions of Approximation of Penal Legislation within the European Union' (2005) 12 MJ 149.
} 
requirement would be 'outmoded since the participants in the procedure (Member States) both regard the conduct which gives rise to the request as criminal...for the reasons stated, reciprocity and double criminality are presumed for certain offences. ${ }^{, 41}$

\section{Shared Experience of a Wrong?}

However, in order for its punishment to be justified, a particular act must not only be considered a public wrong in the abstract by a particular community but it must concern that particular community; it must be a wrong against that community. ${ }^{42}$ Does this shared conception of a wrong translate into something deeper - a shared experience of the wrong and hence the reflection of a wider supranational community capable of being wronged in this sense?

For Lööf the EAW system assumes a single social contract throughout the Union. ${ }^{43}$ The social contract is established as a mechanism for regulating relations between individuals inter se and in the field of criminal law amounts to a mutual commitment to restrict freedom for the promotion of liberty. The legitimacy of state action and the use of force arises from this network of horizontal relations established between citizens through the social contract and the implicit consent that goes with it. ${ }^{44}$ In order for the EAW system to be considered legitimate the system of shared enforcement it involves implies that political relations are established not simply within a particular Member State but amongst individuals throughout the Union; that the Union represents a single social contract.

The truth is perhaps somewhat more nuanced. The legal provisions and the responsibilities they establish imply not a single social contract, or rather not a single homogenous and undivided social contract between Union citizens but a plural, differentiated social contract mediated by national political communities. Within the operation of the EAW system the crime remains (trans)national and is directly experienced by national communities. It is in

\footnotetext{
${ }^{41}$ Advocaten voor de Wereld (n 35) Opinion of Ruiz-Jarabo, paras 45-47.

${ }^{42}$ A strict application of this principle would render problematic ordinary processes of extradition law.

${ }^{43}$ Robin Lööf, 'Defending Liberty and Structural Integrity: A social contractual analysis of criminal justice in the EU' (PhD thesis, Department of Law, European University Institute 2008) Title II.

${ }^{44}$ For the consent basis for legitimacy see Knowles (n 27) ch 7. It is therefore the original social contract between individuals inter se in forming a community rather than a subsequent social contract between the community and the government that is at stake for Lööf. See JW Gough, The Social Contract: A Critical Study of its Development (2 edn, Clarendon Press 1957).
} 
accordance with national criminal law that the act is considered wrongful and its seriousness is likewise assessed according to national criminal law. More importantly, as described above, in contrast to the enjoyment of rights, in the enforcement of transnational responsibilities the role of the executing Member State is transitory. The individual is returned to the issuing Member State to stand trial or to serve punishment. The calling to account and the secular penance is served vis-à-vis the issuing Member State - the Member State against whom the wrong has been committed. ${ }^{45}$ The executing Member State acts merely as an agent for the issuing Member State in a specific, intermediate role - that of detaining and returning the individual. The wrong is still considered primarily against the issuing Member State. And the direct victim of the offence is the political community it represents; it remains a (trans)national rather than a supranational wrong.

However, that is not to say that in addition to the wrong to the national community, there is no supranational wrong. The concept of a shared wrong, developed by Duff and Marshall in the national context in relations between individual citizens, may be applied by analogy. ${ }^{46}$ For Duff and Marshall a wrong directly experienced by an individual becomes a matter of public concern not (simply) because of its potential effect on public order and the need to secure a law abiding environment within which individuals can enjoy their rights. ${ }^{47}$ The 'publicness' of the wrong is more fundamental. It is because of the direct victim's standing as a member of the community that the wrong is in fact shared by the community as a whole. It is because an individual has harmed one that he harms all; it is through the harm and suffering of the individual that the community is harmed vicariously. ${ }^{48}$ The same logic could be applied as between Member States who are members of the same meta-community; because you have directly wronged one community, you have indirectly wronged all communities. There is therefore a supplementary, indirect and vicarious supranational

\footnotetext{
45 Although note the system of supranational responsibility established in the area of the transfer of sentences and EAW Framework Decision (n 2) article 4(6). See further chapter 3.

${ }^{46}$ See also chapter 6 .

47 Although of course sufficiently serious perturbation of public order itself may be a sufficient reason to consider a particular wrong as something that concerns the public. There certainly is an effort on the part of EU institutions to legitimise the EAW and related mutual recognition instruments in this light; claiming that in an area of free movement the maintenance of public order and the corresponding effective enforcement of criminal law throughout the Union justifies mutual recognition instruments. See the assessment of the discourse surrounding the AFSJ by Kostakopoulou in Dora Kostakopoulou, 'The Area of Freedom, Security and Justice and the European Union's Constitutional Dialogue' in C. Barnard (ed), The Fundamentals of EU Law Revisited, vol XVI/2 (OUP 2007). See also the comments of Twomey regarding the Union's efforts to construct a 'secure space'. See Patrick Twomey, 'Construcuting a Secure Space: The Area of Freedom, Security and Justice' in David O'Keefe and Patrick Twomey (eds), Legal Issues of the Amsterdam Treaty (Hart 1999).

${ }^{48}$ See RA Duff and SE Marshall, 'Criminalization and Sharing Wrongs' (1998) 11 CJLJ 7.
} 
dimension to the wrong that involves the entire Union. The wronging of one national community is of public concern for the Union as a whole. It is through the commission of a national wrong that the supranational interest is engaged and hence the participation of all Member States in a system of shared enforcement is justified. This reconciles the undeniable national character of criminal wrongs - as seen not only by the structure of enforcement but also in the interaction of the principle of social integration with criminal law ${ }^{49}$ - with the role of all other Member States in the enforcement of that wrong.

The wrong is now assessed with reference to the Union as a whole, it is in a sense experienced throughout the Union and the Member States collectively share a conception of the wrong. The act is considered wrongful and criminal throughout the territory of the Union. The national normative judgment regarding what acts are criminal that is detached from national territory through transnational enforcement re-emerges at a supranational level. The principle of legality is met in a two-fold transnational and supranational sense; on the one hand the formal legality of the criminal prohibition is assessed under the law of the issuing Member State through a transnational form of legality; it is under this law that the act is formally designated as criminal and the individual punished. However, that is supplemented by a supranational endorsement that implies a shared understanding of the wrongful character of the act throughout the Union and that justifies the executing Member State's participation in the enforcement of that law. The common supranational conception and experience of the wrong supports the claim of transnational legality and underpins the transnational enforcement.

There is therefore a complementarity between the operation of the EAW FD and the shared system of enforcement it creates and the operation of the ne bis in idem principle found in Article 54 of the Convention Implementing the Schengen Agreement (CISA). ${ }^{50}$ As described in further detail in Chapter 6, through an interpretation of the principle contained in Article 54 CISA motivated by the need to secure the free movement of individuals, the Court of Justice has been led to construct a single status for individuals with reference to a single territory. This in turn implies that an individual's wrongful conduct is considered with reference to the Union as a whole and that by being called to account before a single Member State he is called to account indirectly for the Union as a whole.

\footnotetext{
${ }^{49}$ See chapters 3-4.

${ }^{50}$ Convention on the Implementation of the Schengen Agreement (CISA).
} 


\section{Legitimising Shared Enforcement III Supranational Rights}

\section{Legitimacy and Rights}

The final element in the legitimacy of criminal enforcement and punishment relates not to the relationship of the community with the individual or the individual's actions but with its own conduct. Legitimacy is a function of the belief a particular actor has that power is exercised in conformity with accepted norms. ${ }^{51}$ The legitimacy of the EAW system therefore must also rest on a shared belief in the justice of the underlying criminal procedures. In order to participate in the system of shared enforcement Member States and individual actors judges, prosecutors and perhaps above all suspects - should be confident in this element of the legitimacy of punishment - that of competence in protecting the rights of the accused and ensuring a just outcome; ${ }^{52}$ because they are being asked to participate in the enforcement of another Member State's criminal justice system, their belief in its compliance with certain norms is also of relevance. It is this third element of legitimacy that has given rise to the problem that is mutual trust.

Mutual trust and its relationship with mutual recognition present a paradox; the greater the absence of equivalent measures the greater the need of mutual trust, but it is precisely the absence of equivalence that renders the existence of trust less likely. ${ }^{53}$ Mutual trust - either in the internal market or in the area of freedom, security and justice - requires a certain degree of equivalence. ${ }^{54}$ Commentators have deplored the lack of equivalence in the operation of

\footnotetext{
${ }^{51}$ For the relationship between belief, norms and legitimacy in the context of political regimes see David Beetham, The Legitimation of Power (1 edn, Humanities Press Int 1991). Beetham's theory has the benefit of combining what Weiler terms social and normative legitimacy; it is the social belief in a particular set of norms that together creates legitimacy in a particular population. See Joseph Weiler, 'In the Face of Crisis: Input Legitimacy, Output Legitimacy and the Political Messianism of European Integration' (2012) 34 Journal of European Integration 825, 827-828. See also Gráinne de Búrca, 'The Quest for Legitimacy in the European Union' (1996) 59 MLR 349, 349.

52 The criminal process is therefore a system of imperfect procedural justice in which the procedure is designed in order to secure a just outcome according to independent criteria of justice (ie guilt or innocence). The justice or otherwise of the procedure depends on the extent to which it is capable of arriving at the just outcome ie criteria of accuracy rather than the procedure itself being inherently just (so called pure procedural justice). See John Rawls, A Theory of Justice (Harvard UP 1971) 85 ff.

53 See Miguel-Poiares Maduro, 'So close and yet so far: the paradoxes of mutual recognition' (2007) 14 JEPP 814.

${ }^{54}$ Although note that the absence of equivalence is precisely the exceptional characteristic of the operation of the $n e$ bis in idem principle in Article 534 CISA. See chapter 6.
} 
the EAW FD and hold this up as the underlying basis for an absence of mutual trust and hence the problems of legitimacy associated with the EAW FD. ${ }^{55}$ The accusation is that executing Member States are being obliged to participate in the enforcement of the issuing Member State's criminal law but in the absence of any guarantees that the issuing Member State's procedures comply to the same extent with basic norms of procedural justice. However, while it is true that there has, until recently, been an absence of any explicit harmonised regime in the area of criminal justice in the area of rights, that situation is albeit slowly - changing, as the Treaty of Lisbon introduces a legal basis for procedural harmonisation and the Union legislature responds to the criticisms levelled by scholars and practitioners. Furthermore, this ignores the presence of certain common standards of fundamental rights present at a Union level that emerges from the caselaw of the Court of Justice.

\section{Abolition of National Fundamental Rights Control}

States may refuse to cooperate in extradition proceedings where they fear an individual's fundamental rights might be prejudiced. ${ }^{56}$ The reasoning behind this is clear: the extradition of an individual to a state where he or she would be subject to violations of his or her fundamental rights would amount to complicity in a breach of the very standards that the extraditing state undertakes to uphold. It would in effect be co-responsible for a violation of fundamental rights, an act that according to its own legal order is forbidden. Again the link between the norms of a particular legal order and the territory of the state is clear; any use of force on the territory of the state must be in accordance with fundamental rights guarantees of that particular legal order.

Upon the adoption of the European Arrest Warrant Framework Decision it was unclear whether Member States could still impose a control based on fundamental rights, or, to put it another way, whether a potential breach of fundamental rights would constitute a valid reason for refusing to surrender an individual. Some authors claimed that Member States were indeed still subject to fundamental rights obligations and that consequently a possible

\footnotetext{
${ }^{55}$ See in particular Möstl (n 3).

${ }^{56}$ For the operation of this principle in the context of the ECHR see Soering v United Kingdom Series A no 161. A similar principle operates in respect of the Irish constitution. See Attorney General v O'Gara [2012] IEHC 179.
} 
breach could form a valid exception. ${ }^{57}$ They pointed in particular to obligations held by the Member States by virtue of Article 6 of the European Convention on Human Rights $(\mathrm{ECHR})^{58}$ on the right to a fair trial. The European Court of Human Rights (ECtHR) has held that Contracting Parties are prohibited under Article 6 ECHR from extraditing an individual where there would be a real risk that his or her rights under Article 3 ECHR on the prohibition on torture or degrading treatment would be violated. ${ }^{59}$ The strength of this argument would appear to be reinforced by Recital 12 of the EAW FD itself, which affirms the framework decision's compatibility with fundamental rights and Article 6 TEU and the Charter of Fundamental Right (CFR) in particular and Article 1(3) EAW FD stating that the Framework decision shall not modify fundamental rights obligations under Article 6 TEU. ${ }^{60}$ On this basis, when implementing the EAW FD into national law, some Member States included an express provision allowing or requiring refusal to surrender an individual where to do so might violate his or her fundamental rights. ${ }^{61}$

However, the general rule of the framework decision is that mutual recognition and surrender should be automatic. The only grounds for refusal are the mandatory and optional grounds listed in Articles 3 and 4. These grounds are exhaustive. While there are guarantees and protections for specific violations of fundamental rights, for example for in absentia trials, there are no grounds for refusal on a general fundamental rights ground. Recital 12 could be read simply as a reference to the general principle that all Union acts must comply with the fundamental rights standards of the Union in their operation, rather than founding a specific grounds for refusal to surrender. Indeed, in assessing the Member State's implementation of the framework decision, the Commission has argued that there is no right to refuse to surrender based on fundamental rights. ${ }^{62}$ Furthermore, recital 12 of the EAW FD stresses the principle of mutual trust in the operation of the framework decision and that its

\footnotetext{
${ }^{57}$ For an example see Susie Alegre and Marisa Leaf, 'Mutual Recognition in European Judicial Cooperation: A Step too Far too Soon? Case Study - the European Arrest Warrant' (2004) 10 ELJ 200.

${ }^{58}$ Ibid.

${ }^{59}$ Soering $v$ United Kingdom (n 56).

${ }^{60}$ EAW Framework Decision (n 2) recital 12 and art 1(3).

${ }^{61}$ See European Commission, Report from the Commission based on Article 34 of the Council Framework Decision of 13 June 2002 on the European arrest warrant and the surrender procedures between Member States (COM(2006) 8 final, 2006), 6: 'Contrary to what certain Member States have done, the Council did not intend to make the general condition of respect for fundamental rights an explicit ground for refusal in the event of infringement.' For a specific national example see the Irish European Arrest Warrant Act 2003 s 37. For an account see Elaine Fahey, EU Law in Ireland (Clarus Press 2010) 110-113. Ireland subsequently amended its implementing legislation on this, and indeed many other matters.

62 Commission, Report from the Commission based on Article 34 of the Council Framework Decision of 13 June 2002 on the European arrest warrant and the surrender procedures between Member States (n 39) 6.
} 
suspension may only take place after a determination by the Council that a serious and persistent breach of the ECHR has taken place with respect to a particular Member State. ${ }^{63}$ The Court has confirmed that Member States may not refuse to surrender based on a fundamental right found in the national legal order based on the principles of effectiveness and primacy. ${ }^{64}$ Thus Member States are not entitled to subject their participation in the EAW system to fundamental guarantees typically contained in the national legal order. However, that is not to say that there is no fundamental rights protection. Instead, the fundamental rights that are set aside at a national level are replaced by a common, supranational conception of fundamental rights. ${ }^{65}$ Furthermore, the Union legislature has, in recent years been active in developing a common set of supranational procedural rights.

\section{Supranational Procedural Rights}

The elaboration of EU criminal law and mutual recognition instruments in particular enjoyed a major boost following the terrorist attacks of 11 September $2011 .^{66}$ Like much criminal law of the period, EU criminal law was security driven and focused on effective enforcement. ${ }^{67}$ The recently created AFSJ was accused of being heavy on security and light on freedom and justice $^{68}$ with security being the key term in the discursive chain linking freedom, security and justice. ${ }^{69}$ The tide began to turn somewhat with the coming into force of the Treaty of Lisbon and the introduction of the Stockholm Programme in $2014 .^{70}$ A new focus on procedural rights emerged to compensate for the perceived security bias. A procedural rights roadmap was adopted in which the institutions undertook to adopt measures in four key areas ${ }^{71}$ translation and interpretation; information regarding rights of accused persons; legal

\footnotetext{
${ }^{63}$ EAW Framework Decision (n 2) recital 12.

${ }^{64}$ Case C-399/11 Stefano Melloni v Ministerio Fiscal EU:C:2013:107.

${ }^{65}$ Whether this level is adequate or indeed respects the principle of constitutional identity are separate questions. See Leonard Besselink, 'The Parameters of Constitutional Conflicts after Melloni' (2014) 39 EL Rev 531.

${ }^{66}$ See generally Cian Murphy, EU Counter-Terrorism Law: Pre-Emption and the Rule of Law (Hart 2012).

${ }^{67}$ See in particular the security focused Hague Programme (The Hague Programme: Strengthening Freedom, Security and Justice in the European Union [2005] OJ C 53/1)

68 Estella Baker, 'The European Union's "Area of Freedom, Security and (Criminal) Justice" Ten Years On' [2009] Crim LR 833.

${ }^{69}$ Kostakopoulou (n 47) 174.

70 The Stockholm Programme: An Open and Secure Europe Serving and Protecting Citizens [2010] OJ C 115/01. See for the AFSJ more generally Steve Peers, 'Justice and Home Affairs since the Treaty of Lisbon: A Fairy Tale Ending?' in Diego Acosta Arcarazo and Cian Murphy (eds), EU Security and Justice Law (Hart 2014).

${ }^{71}$ Resolution of the Council on a Roadmap for strengthening procedural rights of suspected or accused persons in criminal proceedings [2009] OJ C 295/1.
} 
advice and the right to communicate with lawyers and third persons and finally specific measures regarding particularly vulnerable accused persons. In addition, the Roadmap promised a green paper on the issue of pre-trial detention. Legislation has been adopted with respect to three of these measures; rights to interpretation and translation; ${ }^{72}$ rights to information ${ }^{73}$ and the right to legal advice and to communicate with other parties. ${ }^{74}$

These measures are an explicit effort to strengthen mutual trust within the context of mutual recognition. As with substantive criminal law competence under Article 83(2) TFEU, ${ }^{75}$ there is no autonomous competence to develop a body of procedural rights for individuals; it is seen merely as an ancillary mechanism of underpinning the operation of mutual recognition instruments through reinforcing mutual trust. This ancillary function is stressed by the instruments themselves, all of which directly reference the problem of mutual trust in the context of the free movement of judicial decisions in their recitals. ${ }^{76}$ The link with the problem of mutual recognition and the EAW FD in particular is further underlined by the existence of specific provisions for EAW FD proceedings. ${ }^{77}$

However, despite their ancillary nature, these measures nonetheless do both create and presume a certain common standard and even common content of procedural rights across the Union. On the one hand they do create certain justiciable procedural rights under Union law, enforceable before the courts of Member States in a variety of key areas, most notably the right to a lawyer. ${ }^{78}$ Moreover, all these instruments refer to rights contained in the ECHR and in the ECtHR's jurisprudence and the CFR and therefore considered common to the Member States. Furthermore, although concerned with information to rights and access to resources such as legal advice and translation, leaving the exact content of those rights to be

\footnotetext{
72 Directive 2010/64/EU on the right to interpretation and translation in criminal proceedings [2010] OJ L 280/1.

${ }^{73}$ Directive 2012/13/EU on the right to information in criminal proceedings [2013] OJ L 142/1.

${ }^{74}$ Directive 2013/38/EU on the right of access to a lawyer in criminal proceedings and in European arrest warrnat proceedings, and on the right to have a third party informed upon deprivation of liberty and to communicate with third persons and with consular authorities while deprived of liberty [2013] OJ L 294/1.

75 See further chapter 7.

${ }^{76}$ Roadmap on Procedural Rights (n 71), Directive on Interpretation and Translation in Criminal Proceedings (n 72) recital (3), Access to a Lawyer Directive (n 74) recital (4), Directive on the Right to Information in Criminal Proceedings (n 73) recital (4).

${ }^{77}$ Directive on Interpretation and Translation in Criminal Proceedings (n 72) art 3(6), Directive on the Right to Information in Criminal Proceedings (n 73) art 5 and Access to a Lawyer Directive (n 74) art 10.

${ }^{78}$ There are no cases as yet regarding the direct effect or otherwise of such rights but they are clearly rights held by individuals and there certainly is a case to be made for many of the provisions that they are sufficiently clear, precise and enforceable to enjoy the quality of direct effect. It will also be noted that unlike the EAW FD they are directives and hence capable (provided the above mentioned conditions are met) of enjoying direct effect.
} 
determined by national law, in some areas these directives assume a common core of substantive rights. Thus in the Directive on the Right to Information Member States are obliged to inform suspects regarding rights to access a lawyer and the right to remain silent. ${ }^{79}$ Suspects are subsequently to be provided with a Letter of Rights outlining rights to access the materials of the case and the length they can be detained before being brought before a judicial authority, implying those rights do in fact exist under national law. ${ }^{80}$ Similarly, the Access to a Lawyer Directive references not only the right to be able to access a lawyer, but also the consequences of not having access to a lawyer on legal proceedings and the admissibility of evidence obtained under such circumstances, ${ }^{81}$ again assuming a certain common standard regarding circumstances under which evidence may be excluded in criminal proceedings.

While perhaps arriving somewhat late in the day and advancing in a piecemeal fashion, a common set of procedural rights is emerging through Union law as a direct consequence of mutual recognition instruments. This is occurring both directly - as certain core rights, such as the right to access a lawyer are codified by Union law - and indirectly, as underlying rights of information and access contain assumptions regarding a common procedural tradition. It is through the need to legitimise a transnational system of shared enforcement of national law that certain supranational rights are emerging.

\section{Supranational Fundamental Rights}

The references of these procedural instruments to common standards of rights based in the ECHR and the CFR are not by accident and refer to the broader constitutional context of rights protection within the EAW system. Contrary to certain disappointed reactions to Melloni $^{82}$ and Radu, ${ }^{83}$ the Court of Justice has not found that concerns regarding fundamental rights must be swept aside entirely in the interests of primacy and effectiveness of EU criminal law. What it has unequivocally held is that Member States may not refuse to surrender an individual based on national standards of fundamental rights where to do so

\footnotetext{
${ }^{79}$ Directive on the Right to Information in Criminal Proceedings (n 73) art 3.

${ }^{80}$ Ibid arts 3 and 4.

81 Access to a Lawyer Directive (n 74) recital (50).

${ }^{82}$ Melloni (n 64).

${ }^{83}$ Case C-396/11 Ciprian Vasile Radu EU:C:2013:39. For a comment see Anita Davies, 'Radu - A Case of Failed Dialogue' (eutopia law Blog, 5 February 2013) < http://eutopialaw.com/2013/02/05/radu-a-case-offailed-dialogue/\#more-1755> accessed 14 February 2013.
} 
would compromise the operation of an EAW. Instead, it has replaced these domestic standards with common Union-wide standards, used to police a certain presumption of compliance by Member States. Again it is transnational system of shared enforcement implying a shared supranational framework of rights protections.

Primacy, effectiveness and the unity of EU law ${ }^{84}$ have always been linked to the development of fundamental rights in the Union and it would be naïve to assume that this dynamic would not operate in the field of AFSJ mutual recognition instruments. According to received wisdom, fundamental rights were developed at a supranational level in order to allay the fears of national constitutional courts and head off any challenge from that quarter to the continued primacy of EU law. ${ }^{85}$ What mutual recognition regimes in the AFSJ have brought to this equation is the additional element of a presumption of horizontal compliance between Member States with common standards of fundamental rights when operating within mutual recognition regimes. Whether such presumptions are justified may be arguable and the extent to which they are compatible with ECHR obligations remains an open question ${ }^{86}$ but it is undoubtedly the case that they are linked to the question of primacy and deemed necessary by the Court of Justice for the effective operation of these mutual recognition systems. ${ }^{87}$ This point has more recently been underlined in the recent Opinion 2/13 on the accession of the EU to the ECHR. ${ }^{88}$ What this entails, in the area of criminal law, is a presumption of common standards of fundamental rights.

In Radu the Court of Justice found that Romania could not refuse to surrender one of its nationals to Germany on the basis that he was not informed of the German procedures issuing the EAWs. In its reference the referring court raised a series of general questions regarding the status of fundamental rights in the Union legal order and in the operation of the

\footnotetext{
${ }^{84}$ For a discussion of this new conceptual trinity that appeared in Melloni (n 64) see Besselink (n 65), 543.

${ }^{85}$ Damian Chalmers, Gareth Davies and Giorgio Monti, European Union Law (3 edn, CUP 2014) 252. See also Jason Coppel and Aidan O'Neill, 'The European Court of Justice: Taking Rights Seriously?' (1992) 29 CML Rev 669. Although for an alternative reading of the development of fundamental rights in the EU see Gráinne de Búrca, 'The Road Not Taken: The European Union as a Global Human Rights Actor' (2011) 105 AJIL 649.

${ }^{86}$ See Alexander Kornezov, 'The Area of Freedom, Security and Justice in Light of the EU Accession to the ECHR - Is the Break-up inevitable?' (2012-2013) 15 CYELS 227. See also recent jurisprudence of the Court of Justice in Case C-394/12 Shamso Abdullahi v Bundesasylamt EU:C:2013:813 and the ECtHR in Tarakhel $v$ Switzerland App no 29217/12 (ECHR 4 November 2014) in the area of the transfer of asylum applications under the Dublin system.

${ }^{87}$ See Joined Cases C-411/10 and C-493/10 NS v Secretary of State for the Home Dept EU:C:2011:865, [2011] ECR I-13905. Indeed, the Court claimed that to allow suspension of mutual recognition regimes on a case-bycase basis would call into question the raison d'être of the EU itself and the creation of an AFSJ (ibid para 83). ${ }^{88}$ Opinion 2/13 Opinion 2/13 EU:C:2014:2454.
} 
EAW FD in particular. Avoiding the general questions, the Court in its reply limited itself strictly to the situation in hand, and found that a refusal to notify an individual when issuing EAWs was not a breach of their fundamental rights. While some commentators read Radu as an implicit rejection by the Court of Justice of fundamental rights as a grounds for refusal, ${ }^{89}$ in truth the ratio of the judgment is much narrower, simply refusing to find a breach in the circumstances of the case, and leaving open the broader question of the status of fundamental rights, and the possibility of them constituting a grounds for refusal. ${ }^{90}$

What became clear however in Melloni is that Member States may not refuse to surrender an individual based on their own, domestic standards of fundamental rights; at least where to do so would frustrate the effective application of the EAW, an almost inevitable outcome if the consequence of such an application would be the refusal to surrender an individual. ${ }^{91}$ In Melloni an Italian national skipped bail and was convicted of fraud in absentia. He was later arrested in Spain and was subject to surrender proceedings based on an Italian EAW. Due to the fact that he was aware of his trial and was represented at all stages of the process he would not be granted a retrial upon return to Italy. The Spanish Constitution prohibited extradition in such circumstances, considering to do so would breach the fundamental right to a fair trial. Article $53 \mathrm{CFR}$ states that 'nothing in this charter shall be interpreted as adversely affecting human rights and fundamental freedoms as recognised, in their respective fields...by the Member States' constitutions. ${ }^{92}$ The Spanish Constitutional Court therefore referred a question to the Court of Justice, seeking in particular to know whether Article 53 CFR allowed the application of the Spanish constitution in this case. In its reply the Court rejected the possibility that the Spanish Court could apply its own constitutional provisions and refuse to surrender Mr Melloni. The Court of Justice based its argument on the principle of primacy and found that to allow the application of national provisions would allow Member States to disapply Union law and undermine its effectiveness.

While some might read Melloni as a disappointment and further evidence of the lack of fundamental rights protection in criminal justice matters, ${ }^{93}$ a careful reading of both Radu and Melloni does not exclude any form of fundamental rights control. Rather, Radu is silent

\footnotetext{
${ }^{89}$ See Davies (n 83).

${ }^{90}$ For such an analysis see Janssens (n 4) 207-210.

${ }^{91}$ Melloni (n 64).

${ }^{92}$ CFR art 53.

93 See ex Besselink (n 65).
} 
on the general issue, merely finding that a breach of fundamental rights did not take place, and Melloni on the contrary does subject the EAW system to a fundamental rights control but one based on Union provisions of fundamental rights, in particular the Charter of Fundamental Rights. Melloni makes two findings. Firstly, it finds that surrendering $\mathrm{Mr}$ Melloni in the circumstances of the case, namely where there was a verdict handed down in absentia but the accused appointed representatives who did in fact represent him throughout the trial, does not amount to a breach the right to a fair trial found in Article $47 \mathrm{CFR}{ }^{94}$ This is particularly the case in light of the adoption of Framework Decision 2009/299/EU amending the EAW FD to provide greater protection in the case of in absentia trials ie a harmonisation of the conditions in which the right to trial is compromised by the absence of the accused. ${ }^{95}$ The Court does assess the compliance of the EAW FD with fundamental rights but it is an assessment of a Union law instrument in light of Union fundamental rights. Secondly, it found that Spain may not apply its constitutional provisions where to do so would undermine the effectiveness of the EAW FD. But note that the Spanish Court's 'interpretation of Article 53 of the Charter would undermine the principle of the primacy of EU law inasmuch as it would allow a Member State to disapply EU legal rules which are fully in compliance with the Charter where they infringe the fundamental rights guaranteed by that State's constitution.' (emphasis added). ${ }^{96}$ Similarly, in the subsequent case of Jeremy $F$ the Court was at pains to point out that the system of mutual trust on which the EAW system is based is founded on compliance by the Member States with 'fundamental rights recognised at Union level, particularly in the Charter'. ${ }^{97}$

There is an implication that where Member States are not in compliance with the Charter, there is a possibility that the execution of an EAW may be refused. The exact circumstances where this might happen still need to be determined. It is entirely possible that the Court will draw inspiration from its judgement of $N S$ in the area of the transfer of asylum seekers under the Dublin System ${ }^{98}$ and find that it would be necessary to find a systematic, serious and

\footnotetext{
${ }^{94}$ Melloni (n 64) paras 49-50.

95 Interestingly the Court describes this Framework Decision as reflecting a consensus amongst Member States regarding the appropriate criteria according to which one should assess the compatibility of an in absentia trial with fundamental rights. See ibid, para 62. Note however Besselink's perceptive point that this consensus was achieved amongst the governments of Member States, allowing executives to thereby circumvent national fundamental rights guarantees. See Besselink (n 65) 548.

${ }^{96}$ Melloni (n 64) para 58.

${ }^{97}$ Case C-168/13PPU Jeremy F v Premier ministre EU:C:2013:358 para 47.

98 Regulation 343/2003/EC establishing the criteria and mechanisms for determining the Member State responsible for examining an asylum application lodged in one of the Member States by a third-country national
} 
persistent breach of fundamental rights to rebut the presumption, based on mutual trust, that Member States comply with fundamental rights obligations as found in the CFR and other Union sources of fundamental rights and the ECHR. ${ }^{99}$ It is noteworthy that the new European Investigation Order Directive contains precisely such a control, allowing Member States to refuse to execute a European Investigation Order (EIO) in such circumstances. ${ }^{100}$

Thus, while the Court has not yet explicitly decided on the question of fundamental rights as a ground for refusal it is likely that surrender may be refused based on a potential violation of fundamental rights, but only where there is evidence of a persistent and systematic breach and only by reference to Union standards of fundamental rights. However, in such a situation the Member State would no longer be exercising an autonomous normative control, applying its own standards to prevent an individual from being surrendered, but would rather be acting as an agent under Union law. It would be applying Union law and Union fundamental rights in order to maintain the integrity of the Union legal order and in particular the system of shared enforcement established by the EAW FD.

\section{Conclusion}

\section{Transnational Enforcement in a Supranational Space}

Criminal law is intimately linked to the concept of territorial control and the legitimate use of force. The establishment of a transnational system of enforcement and the subsequent loss of control by Member States over how individuals on their territory are treated has significantly disrupted traditional understandings of citizenship, fundamental rights, questions of legality and ultimately their relationship with the legal order and the territory of a particular Member State. It has above all called into question the traditional national framework for assuring the legitimate use of force on a particular territory.

The EAW is above all a transnational system of enforcing national wrongs. As the Court of Justice stated in Advocaten voor de Wereld, the EAW does not itself define or create crimes.

[2003] OJ L50/1 since replaced by the Regulation 604/2013 establishing the criteria and mechanisms for determining the Member State responsible for examining an application for international protection lodged in one of the Member States by a third-country national or a stateless person (recast) [2013] OJ L180/31.

99 For an analysis see Cathryn Costello, 'Courting Access to Asylum in Europe: Recent Supranational Jurisprudence Explored' (2012) 12 HRL Rev 287, 324 ff.

${ }^{100}$ EIO Directive (n 13), art 11(f). Note the exception operates with reference to Article 6 TEU and the CFR rather than national fundamental rights standards. 
Those crimes are defined by particular national communities and it is before those communities that individuals return to be called to account or to serve punishment. Indeed, the essentially national nature of crimes is in some respects strengthened by the EAW system; unlike extradition systems with their rule of double criminality it is exclusively under the law of the issuing Member State and at the discretion of the issuing Member State that an individual's conduct is assessed. It is a transnational system of enforcement, of calling citizens to account before national communities for national wrongs.

However, it is only by framing national norms and values within the single supranational space occupied by Union citizens that an effective system of transnational enforcement can be justified and legitimised. Union citizenship has given rise to a broader space of movement and set of political relations between individuals and Member States throughout the Union. Above all it has emplaced individuals in a broader space of rights and now responsibilities. This transnational space of movement and enforcement necessarily generates tensions regarding territory, norms and rights. However, these norms, that are displaced at a national level, re-emerge at a supranational level. The wider geographic space of movement generated by Union citizenship corresponds with a single area of justice, not simply in allowing the 'free movement of judgments' or contributing to a more effective law enforcement, but in generating certain, overarching, norms both in terms of the publically wrongful nature of certain acts and fundamental rights and procedural guarantees. Indeed, not only are there certain supranational norms emerging through the EAW but a supranational community capable of sharing wrongs can also be detected. 


\title{
Chapter 6
}

\section{An Area of Justice II:}

\section{A Transnational Ne Bis in Idem Principle}

\author{
Introduction: \\ Interpretation in Light of Free Movement
}

A German assaults a woman in Belgium, is apprehended and charged by authorities in Bonn and settles the case by agreeing to pay a fine. Meanwhile, in Belgium the victim brings proceedings before the local criminal court. Can the Belgian prosecutor order the assailant to appear before the criminal court in Belgium? ${ }^{1}$ In 1960 a German member of the French foreign legion attacks and kills a fellow German during the Algerian conflict and flees to the German Democratic Republic. He is convicted under French military law but the sentence is later set aside under a general amnesty for acts committed in the Algerian conflict and in any case is time-barred. Later, after the fall of the Berlin wall, Germany seeks to prosecute the by now aged ex-Legionnaire. Are German authorities prevented by the French amnesty and time-limits? ${ }^{2}$ A Belgian is convicted and imprisoned in Norway for importing cannabis and other narcotics. He is later released and returned to Belgium where he is in turn prosecuted for exporting the same substances. Has he already paid his due to society? Is importing drugs the same act as exporting? ${ }^{3}$ A woman receives the proceeds of crime in the Netherlands and later exchanges the same funds in a bureau d'échange in Belgium. Is the woman guilty of handling the proceeds of crime in the Netherlands, Belgium or both? ${ }^{4}$

\footnotetext{
1 Joined Cases C-187/01 and C-385/01 Criminal proceedings against Hüseyin Gözütok and Klaus Brügge EU:C:2003:87, [2003] ECR I-1345.

${ }^{2}$ Case C-297/07 Klaus Bourquain EU:C:2008:708, [2008] ECR I-9425.

${ }^{3}$ Case C-436/04 Criminal proceedings against Leopold Henri Van Esbroeck EU:C:2006:165, [2006] ECR I2333.

${ }^{4}$ Case C-367/05 Criminal proceedings against Norma Kraaijenbrink EU:C:2007:444, [2007] ECR I-6619.
} 
The principle of ne bis in idem is a principle of law common to most legal systems and enjoying a long history. ${ }^{5}$ Its principle purpose is to prevent an individual from being prosecuted twice for the same act or crime. In general it is designed to secure the rights of the individual vis-à-vis the state. However as the above examples illustrate, in a single area characterised by multiple criminal justice systems, individuals can face prosecution from more than one state. Criminal acts are no longer limited by borders, if indeed they ever were, and Member States claim jurisdiction in different and sometimes overlapping ways. The possibility of multiple prosecutions in different parts of the Union represents a major hindrance for anyone seeking to exercise their freedom of movement. In the EU legal order the primary function of the ne bis in idem principle is therefore different from simply protecting the individual from a single abusive state: it is to secure the free movement of individuals, removing obstacles that may exist through the existence of multiple legal orders. In interpreting the principle in light of this particular goal the Court of Justice has constructed a single status for individuals within a single area of justice, a development that in turn reflects a new understanding of the relationship between the individual and other Member States and indeed the Union as a whole.

The principle of ne bis in idem is on its face a relatively simple rule with a straightforward rationale. It is designed to ensure that an individual is not prosecuted more than once for the same crime: its ultimate purpose is to ensure that the outcome of a criminal case is final. The reasons are clear. Firstly, it protects the individual from the possibility of vexatious prosecution, from being constantly hounded by vindictive or simply over-zealous officers of the state. To allow continuous attempts at prosecution would place the individual in a persistent state of risk and fear of prosecution: a burdensome existence fraught with uncertainty. Secondly, it ensures balance in the criminal justice process between the two sides, the famed 'equality of arms' principle. It prevents the state from returning to court in an attempt to prosecute, a possibility that would give it multiple chances to amend and improve its case, an opportunity that is unavailable to the accused. ${ }^{6}$ Finally, while for the most part the principle can be seen as protecting the rights of individuals' vis-à-vis the state,

\footnotetext{
${ }^{5}$ For a history in the common law and in particular American context see Jay A Sigler, 'A History of Double Jeopardy' (1963) 7 The American Journal of Legal History 283.

6 Described by Reed as 'heads-we-win, tails-lets-play-again' as quoted in Robin Löö, '54 CISA and the Principles of ne bis in idem' (2007) 15 Eur J Crime Crim L \& Crim Just 309, 322.
} 
there is also a broader public interest in securing finality in criminal judgments. It therefore is a specific manifestation of the general principle of res judicita and legal certainty. ${ }^{7}$

At the same time the criminal justice process, in addition to protecting the rights and interests of the innocent and providing legal certainty, is also concerned with ensuring that wrongful acts are prosecuted and punished in an appropriate manner that reflects the gravity of the offense. There is an interest in ensuring that the state has an adequate opportunity to call the individual to account and in a manner that reflects all the wrongful aspects of the act. There is a need to ensure that cases can be reopened if further evidence comes to light, that all crimes that a particular act might represent are prosecuted and to ensure that an individual does not escape through a dismissal of his or her case on a technical matter without a proper assessment of the crime.

It is these counter-veiling needs of the criminal justice system - those of the individual and those of the state - that render the interpretation of the ne bis in idem principle, so simple in theory, extraordinarily complicated in practice, with different jurisdictions interpreting what is ostensibly the same rule in diametrically opposed ways and with widely differing results for the individuals concerned. ${ }^{8}$

The principle has two dimensions both of which have given rise to interpretative difficulties. Firstly, the definition of finality: whether a particular case can be said to be finally settled or otherwise. While some cases can clearly be considered to be finally settled - such as a judgment acquitting an individual following a full trial and deliberation that is no longer subject to appeal - there are other cases that fall short of a full trial of all aspects of the case, such as plea bargains. The application of the rule in these cases is less clear. A guiding principle that may be employed is that there should be a substantive assessment of the merits of the case. ${ }^{9}$ However judgments can vary as to what precisely a substantive assessment might entail and the test is not always simple to apply in practice. The second dimension of

\footnotetext{
${ }^{7}$ See Bas van Bockel, The Ne Bis in Idem Principle in EU Law (Kluwer 2010) ch 1.

${ }^{8}$ For an example of a particularly complicated interpretation of the double jeopardy rule see the US Supreme Court's interpretation of the $\mathrm{V}^{\text {th }}$ Amendment. See Akhil Reed Amar, 'Double Jeopardy Law Made Simiple' (196-1997) 106 Yale Law Journal 1807.

${ }^{9}$ See for example the Opinion of AG Sharpston in Case C-467/04 Criminal proceedings against Guiseppe Francesco Gasparini and Others EU:C:2006:610, [2006] ECR I-9199, para 75. See the discussion of the various solutions adopted by the ECtHR in different cases see Zolotukhin v Russia App no 14939/03 (ECrtHR, 10 February 2009) paras 70-77.
} 
the principle relates to determining precisely for what an individual is not to be prosecuted twice (the sameness criteria). ${ }^{10}$ The debate here tends to focus on whether an individual is to be protected from multiple prosecutions for the same act or series of acts or whether it is multiple prosecutions for the same crime that is at stake ie whether sameness refers to crimes or to acts.

The ne bis in idem principle appears in the EU legal order in various provisions. It has long been a feature of the Court's jurisprudence in competition law sanctions. More recently it has appeared in Article 54 of the Convention on the Implementation of the Schengen Agreement (CISA), Article 3(2) of the European Arrest Warrant Framework Decision (EAW FD), Article 50 of the Charter of Fundamental Rights (CFR) and is also contained in Article 4 of Protocol 7 of the European Convention on Human Rights (ECHR).

The current chapter focuses on Article 54 CISA for two reasons. Firstly, there has been a clear convergence between the interpretation of the different legal provisions that contain the ne bis in idem principle in the European legal space both between the ECHR and the EU legal orders and the vertical and horizontal application of the principle. In both instances of convergence this has tended to use the interpretation developed in the context of Article 54 CISA. In Zolotukhin the European Court of Human Rights (ECtHR) resolved the significant uncertainty and divergence that previously existed in its jurisprudence on the interpretation of Article 4, Protocol 7 ECHR by effectively adopting the solution developed in the context of Article 54 CISA. ${ }^{11}$ In Mantello the Court of Justice noted the shared objective of Article 3(2) EAW FD and Article 54 CISA and interpreted Article 3(2) EAW FD in the light of its jurisprudence based on Article 54 CISA. ${ }^{12}$ In $M$ the Court found that Article 54 CISA was merely a specific expression of the general principle found in Article $50 \mathrm{CFR}$, which itself is to be interpreted in light of Article 4, Protocol 7 ECHR. ${ }^{13}$ Thus, through various chains of interpretation there appears to be a general convergence within the EU legal order between Article 54 CISA, Article 3(2) EAW FD, Article 50 CFR and Article 4, Protocol 7 ECHR - all

\footnotetext{
${ }^{10}$ van Bockel (n 7) ch 2.

${ }^{11}$ Zolotukhin v Russia (n 9).

${ }^{12}$ Case C-261/09 Gaetano Mantello EU:C:2010:683, [2010] ECR I-11477 paras 39-40. This was despite the fact that the situation at stake in Mantello was a 'vertical' one. Mr Mantello was resisting surrender from Germany to Italy by claiming he had already been punished under Italian law for the same act. Intervening Member States argued that Article 3(2) EAW FD only applied in transnational contexts, as a corollary to Article 54 CISA. (see ibid, Opinion of AG Bot para 7.).

${ }^{13}$ Case C-398/12 M EU:C:2014:1057 para 35.
} 
based primarily on the jurisprudence developed under Article 54 CISA. The result is a uniform application of the principle in transnational, national and supranational situations that fall within the scope of the Union legal order, ${ }^{14}$ corresponding to the protection found in the ECHR.

Secondly, this chapter is concerned with the relationship between individual citizens, free movement and crime within what has been termed the single area of justice. It is therefore primarily concerned with the impact of multiple prosecutions from different jurisdictions on the movement of individuals within the Union. It deals with what has been termed 'horizontal' and geographic rather than a 'vertical' or temporal application of the principle ie between legal orders in different places rather than within a single legal order over time. ${ }^{15}$ Article 54 CISA is specifically a transnational and horizontal principle. Article 4, Protocol 7 ECHR and Article $50 \mathrm{CFR}$ are primarily concerned with a vertical application of the principle. The use of the principle in the context of competition law proceedings follows very different principles and operates in a very different legal context characterised by its quasi-administrative/criminal nature and the structure of the European Competition Network of competition law authorities applying overlapping legal provisions in a multi-levelled context. $^{16}$

On one level Article 54 CISA reads like any version of the ne bis in idem principle: 'a person that has been finally judged may not be prosecuted ... for the same offences.' However, there is a crucial distinction relating to the scope of the CISA that differentiates it from other versions of the principle found in national and indeed international texts. The full article reads:

\footnotetext{
'A person who has been finally judged by a Contracting Party may not be prosecuted by another Contracting Party for the same offences provided that, where he is sentenced, the sentence has been served or is currently being served or can no longer be carried out under the sentencing laws of the Contracting Party ${ }^{17}$
}

\footnotetext{
${ }^{14}$ A set of situations that may prove to be expansive. See Case C-617/10 Aklagaren $v$ Hans Åkerberg Fransson EU:C:2013:280.

${ }^{15}$ Lööf (n 6).

${ }^{16}$ van Bockel (n 7).

${ }^{17}$ Convention on the Implementation of the Schengen Agreement, Ch 3, art 54 (emphasis added).
} 
In contrast to traditional conceptions of the ne bis in idem principle, Article 54 CISA is not designed to protect the individual against multiple prosecutions within a single state. Rather it is designed to protect the individual against prosecutions from other states and in other legal orders. It is the first application of the principle in a transnational legal setting. ${ }^{18}$

Not only is the scope of Article 54 CISA as a transnational principle different from other manifestations of the ne bis in idem principle, but its rationale is also different. Indeed the different scope of Article 54 CISA quite logically flows from the different purpose of Article 54 CISA. Its purpose lies in the underlying goal of the Schengen Agreement itself, designed to secure free movement of individuals. The Schengen acquis is a body of law with a complicated history. Originally developed outside the scope of Union law amongst a select number of Member States it has since been incorporated within the Treaties ${ }^{19}$ and its scope has been extended, albeit on a phased-basis, to most Member States. The UK and Ireland, reluctant to cede control over their borders have retained opt-outs of the acquis, exercised on a case-by-case basis, but have opted into Article 54 CISA. ${ }^{20}$ Thus, when the Court of Justice refers to free movement in several Member States in the context of Article 54 CISA or indeed the European Union it can be taken as referring to the Union as a whole. Nonetheless, the persistence of opt-outs in this area in particular does underline the continuing fragility of notions of Union territoriality and a single space of movement in a Union of variable geometry.

The Court of Justice has been very clear that the objective of 'Article 54 is 'to ensure that no one is prosecuted on the same facts in several Member States on account of his having exercised his right to freedom of movement. ${ }^{21}$ The primary purpose of Article 54 CISA is therefore not the protection of the individual from vexatious prosecution and to ensure legal

\footnotetext{
${ }^{18}$ Some national legal orders, such as the Dutch unilaterally take into account convictions in other states. See John Vervaele, 'Annotation of Cases C-187/01 and C-385/01 Gözütok and Brügge' (2004) 41 CML Rev 795, 804. An attempt to adopt a multi-lateral Convention by the Council of Europe failed for want of ratifications but was later formed the basis for Article 54 CISA. See Christine van den Wyngaert and Guy Stessens, 'The International Non Bis in Idem Principle: Resoloving Some of the Unanswered Questions' (1999) 48 ICLQ 779.

${ }^{19}$ For a detailed account see Eckart Wagner, 'The Integration of Schengen into the Framework of the European Union' (1998) 25 LIEI 1.

${ }^{20}$ It should be pointed out that the United Kingdom and Ireland have both opted into this part of the Schengen Agreement See Decision 2000/365/EC concerning the request of the United Kingdom of Great Britain and Northern Ireland to take part in some of the provisions of the Schengen acquis [2000] OJ L 131/43 and Council Decision concerning Ireland's request to take part in some of the provisions of the Schengen acquis [2002] OJ L $64 / 20$.

21 Gözütok and Brügge (n 1) para 38.
} 
certainty. That is not to say that Article 54 CISA does not protect individuals and ensure legal certainty; it does achieve these things. But it does so in the service of securing another goal: the free movement of individuals throughout the Schengen area. Legal certainty for the individual is necessary because it is necessary for free movement. The traditional rationale for the ne bis in idem principle is rendered instrumental to the telos of free movement.

If the scope of Article 54 CISA as a transnational principle reflects its telos as a measure designed to secure free movement, that same underlying goal has informed the interpretation of Article 54 CISA. As stated above, the ne bis in idem principle is notoriously difficult to apply and lends itself to various interpretations depending on the definition of sameness or finality. In the context of Article 54 CISA however, the various interpretative choices, normally available to a court when interpreting the principle of ne bis in idem, are conditioned and shaped by the underlying goal to secure free movement in a context of multiple jurisdictions. The interpretation of Article 54 CISA flows directly from the principle of free movement of persons. As with much in EU law ${ }^{22}$ this teleological perspective is key to understanding the reasoning of the Court.

If the technique has been teleological reasoning based on free movement, the consequence has been a re-shaping the relationship between individuals and other Member States in the field of criminal law and indeed between individuals, Member States and the Union as a whole. Directed by the need to secure free movement for individuals, the Court has been lead to fashion a single status for individuals vis-à-vis the Union as a whole. Under this new regime, individuals are called to account by a single Member State but in the name of the Union as a whole. The result is that a crime against a Member State becomes a crime against the Union as a whole: that individual is called to account before the Union through the criminal justice of a single Member State. It is through the transnational process of the ne bis in idem that individuals are called to account in a plural, multi-levelled political community.

\section{Interpretation of Finality in Light of Free Movement: A Single Status}

\footnotetext{
${ }^{22}$ Anthony Arnull, The European Union and its Court of Justice (OUP 2006) ch 16.
} 
The difficulty faced by the Court of Justice in interpreting the concept of finality in Article 54 CISA arises from unique situation of its application across different criminal justice systems with different and not always compatible means of settling cases. The solution is one frequently employed by EU law when faced with obstacles to free movement caused by differences in law between jurisdictions: that of mutual recognition. ${ }^{23}$ It is the decision of the first Member State that determines the status of the individual and it is this decision that must be accepted by all other Member States. However, the principle of mutual recognition is not homogenous in its application across the legal order of the Union. It varies in the degree to which other States are required to accept the decision of the original Member States, which legal order is to govern the particular decision and perhaps most importantly if the second Member State is capable of exercising any controls, either regarding the validity of the original decision or in providing for exceptions including the requirement of a sufficient degree of equivalence between the laws of the original Member State and its own laws. Through a desire to secure the maximum free movement for individuals and hence the maximum degree of certainty for such individuals, the Court of Justice in its elaboration of the principle of mutual recognition in Article 54 CISA has been led to adopt a particularly strict version of the principle of mutual recognition.

Firstly, the Court of Justice has insisted that the ne bis in idem principle operates in the absence of any equivalence. That a decision of a single Member State is to be applied in another Member State is not particular novel. ${ }^{24}$ In fact this structure forms the definitional core of the principle of mutual recognition and lies at the heart of Cassis de Dijon. ${ }^{25}$ However, unlike with other instances of the mutual recognition principle, in particular those found in both the caselaw and legislation of the internal market, Member States are not entitled to subject their acceptance of a decision of another Member State to the condition that there exists a certain degree of similarity or functional equivalence between the laws of the respective Member States. There is no principle of 'mandatory requirements ${ }^{26}$ or "public

\footnotetext{
${ }^{23}$ See generally Christine Janssens, The Principle of Mutual Recognition in EU Law (OUP 2013).

${ }^{24}$ Indeed it may become a technique used increasingly frequently in transnational processes more generally see Kalypso Nicolaidis and Gregory Shaffer, 'Transnational Mutual Recognition Regimes: Governance without Global Government' (2005) 68 Law and Comtemporary Problems 263.

${ }^{25}$ Case 120/78 Rewe-Zentral AG v Bundesmonopolverwaltung für Branntwein EU:C:1979:42, [1979] ECR 649.

${ }^{26}$ Ibid. See also Case C-55/94 Reinhard Gebhard v Consiglio dell'Ordine degli Accoacti e Procuratori di Milano EU:C:1995:411, [1995] ECR I-4165. For a good example of the requirement of equivalence in
} 
policy' derogations or equivalence test ${ }^{27}$ that a Member State can invoke to prevent the operation of a decision to convict or acquit an individual, simply because in its own legal order it does not recognise similar decisions. Article 54 CISA implies that each Member State 'recognises the criminal law in force in the other Member States even when the outcome would be different if its own national law was applied... The application by one Member State of the ne bis in idem principle as set out in Article 54 of the CISA, to procedures whereby further prosecution is barred, which have taken place in another Member State without a court being involved, cannot be made subject to a condition that the first State's legal system does not require such judicial involvement either. ${ }^{28}$ At stake in Gözütock and Brügge was the question of settlement decisions. Precisely the same logic has been applied to instances where cases have been disposed of due lack of evidence, ${ }^{29}$ timelimits on prosecution ${ }^{30}$ and findings of 'non-lieu' or absence of grounds. ${ }^{31}$

The strict version of mutual recognition in the context of the ne bis in idem principle was not uncontroversial and indeed prompted a response from certain Member States. Greece in particular tabled a proposal that, while not directly challenging the Court's judgment in Gözütock and Brügge, did include exceptions allowing a Member State to prosecute in certain situations namely where the security or other 'equally essential interests' of the Member State was threatened, even where another Member State had already done so. ${ }^{32}$ That proposal never gained sufficient support to make it as a legislative instrument into the official journal but it does underline the fact that alternatives existed to the interpretation of the Court of Justice's in Gözütock and Brügge. Instead, the Court set aside the potential concerns of Member States in having some form of equivalence check and insisted on an interpretation that maximised the free movement of individuals.

\footnotetext{
legislation see Directive 98/5/EC to facilitate practice of the profession of lawyer on a permanent basis in a Member State other than that in which the qualification was obtained [1998] OJ L 77/36.

${ }^{27}$ See Janssens (n 23).

${ }^{28}$ Gözütok and Brügge (n 1) paras 33-34.

${ }^{29}$ Case C-150/05 Jean Leon Van Straaten v Staat der Nederlanden and Republiek Italië EU:C:2006:614, [2006] ECR I-9327.

${ }^{30}$ Gasparini (n 9).

${ }^{31} M$ (n 13).

${ }^{32}$ Initiative of the Hellenic Republic with a view to adopting a Council Framework Decision concerning the application of the ne bis in idem principle [2003] OJ C 100/24, art 4(1). The proposal also concerned the related matter of dividing jurisdiction between Member States.
} 
In a complementary move the Court of Justice has found that not only must the decision of the authorities of the first Member State be recognised as valid, even in the absence of equivalence, but that for the purposes of the application of Article 54 CISA, the effect of that decision, and in particular whether it is considered final or otherwise, in the legal order of the second Member State, is to be determined solely by the law of the first Member State. In what can be called the Turansky' principle the Court held that 'in order to assess whether a decision is "final" for the purposes of Article 54 of the CISA, it is necessary first of all to ascertain...that the decision in question is considered under the law of the Contracting state which adopted it to be final and binding, and to verify that it leads, in that State, to the protection granted by the ne bis in idem principle'. ${ }^{33}$ It is by reference to the law of the issuing Member State that the effect of the decision is to be ascertained. Not only is the decision to acquit or convict to be adopted by the first Member State but also the question of its finality, its ultimate effect in definitively regulating the status of the individual, is likewise to be determined by the law of the issuing Member State. Thus in Turanksý whether the decision of a Czech police officer discontinuing an investigation was final or not was to be determined according to Czech law. The outcome of that assessment under Czech law determined whether Austrian authorities could proceed with their own investigations and possible prosecution in Austria. The same formula has been employed by the Court in the subsequent cases of Bourquain ${ }^{34}$ to the situation of general amnesties, and in $M^{35}$ to the situation of non-lieu, or dismissal for lack of grounds.

The result of both of the above inter-related rules - the acceptance of the decision in the absence of equivalence and ensuring that it is the law of the first Member State that determines the finality of the decision - is to grant maximum certainty to the individual. In other areas of mutual recognition the legal position of an individual can be the result of a combination of the decision of the initial legal order and how that decision is accepted and applied in the second legal order. Thus in the area of the mutual recognition of diplomas the ability of the individual to practice a profession in a second Member State depends on a combination of the decision of the first Member State to grant a diploma and the conditions applied by the second Member State to the recognition of that diploma. ${ }^{36}$ The precise status

\footnotetext{
${ }^{33}$ Case C-491/07 Criminal proceedings against Vladimir Turanský EU:C:2008:768, [2008] ECR I-11039 para 35 .

${ }^{34}$ Bourquain (n 2) para 48.

${ }^{35} M$ (n 13).

${ }^{36}$ Janssens (n 23) $91 \mathrm{ff}$ also using the example of driving licences.
} 
of the individual is therefore the result of the combined interaction of rules originating in two legal orders. The outcome is of course variable depending on precisely which two Member States are in question, although harmonising measures can reduce situations of legal uncertainty for individuals. The consequence is firstly greater or lesser free movement between those jurisdictions depending on the precise differences and secondly a degree of variation in the extent of the freedom of movement throughout the Union. With Article 54 CISA however the Court is at pains to ensure the maximum degree of free movement for individuals, both between particular Member States but also across the Union as a whole. To secure such a result the decision of one Member State and only one Member State must be made applicable throughout the Union in the same manner. It is logical and necessary that this be the Member State that adopted the initial decision. ${ }^{37}$ The result is a particularly strict interpretation of mutual recognition in Article 54 CISA. It aims at maximum recognition in an effort to achieve maximum free movement for individuals across all Member States. ${ }^{38}$ As a result, the legal situation of an individual, the status of an individual with respect to a particular crime, is governed not by various combinations of two or even more Member States interacting but by the law of a single Member State and only that Member State. The outcome of this determination is in turn applicable in all other Member States in the exactly same fashion. Both the validity of a decision and its finality is determined by the law of one state and only one state.

\section{A substantive assessment of the merits of the case}

If a desire to secure maximum recognition of the individual's free movement is the principle goal of the Court of Justice in the interpretation of Article 54 CISA, this is not its only goal or concern. The Court is aware of the underlying tension in the ne bis in idem principle namely to ensure that an individual is called to account properly for his actions once and only once but that he should in fact be properly called to account. In line with jurisprudence

\footnotetext{
${ }^{37}$ Logical because a decision to finally settle a case is part of an overall criminal justice system and the rules regarding its effect should take into account other elements of the criminal justice system. To transpose a decision and yet change its ultimate result may ignore this systemic quality. Necessary because once the decision of the first Member State is adopted by necessity any other result will result in variations.

38 Such maximum recognition and in particular the absence of equivalence is dependent on what might charitably be termed the fiction of mutual trust between the legal orders of Member States. Maduro has lucidly pointed out the paradox of the operation of the twin principles of mutual recognition and mutual trust in the context of variations between legal orders: it is precisely when variation between legal orders is greatest and mutual trust less likely to exist, that it needs to be relied and asserted by the Court to the greatest extent. If there was in fact real mutual trust between Member States, there would be no need to insist on it. See Miguel-Poiares Maduro, 'So close and yet so far: the paradoxes of mutual recognition' (2007) 14 JEPP 814.
} 
and pronouncements in the area of mutual recognition of judgements and in particular the European Arrest Warrant Framework Decision (EAW FD), ${ }^{39}$ the Court wishes to ensure that the EU remains or indeed becomes, an area of justice, meaning that individuals should face justice for their wrongful actions and that they be properly called to account before a Court. Article 54 CISA should not therefore be used as a mechanism to evade justice.

The Court has accordingly insisted there be a 'substantive assessment of the merits of the case. ${ }^{40}$ The Court does not elaborate precisely what this entails but it can be assumed that there must occur in one Member State an assessment of the actions of an individual in light of all the relevant facts either during a trial or by a competent authority in relation to a decision whether to try or not. Thus a case discontinued for the simple reason that another Member State, better situated, commenced an investigation, cannot be considered finally disposed of for the purposes of Article 54 CISA. ${ }^{41}$ In Miraglia, in which Dutch authorities suspended their investigation because the Italian authorities had begun their own investigation, there was simply 'no assessment whatsoever of the unlawful conduct with which the defendant was charged'. ${ }^{42}$ The Italian authorities were not therefore prevented from prosecuting. A decision 'where no determination has been made as to the merits of the case, cannot constitute a decision finally disposing of the case against that person within the meaning of Article 54 of the CISA. ${ }^{43}$ Similarly in Spasic the fact that an individual had only served the pecuniary and not the custodial element of his sentence had the result that his sentence was not in the process of being enforced within the meaning of Article 54 CISA. To hold otherwise would mean an individual could evade justice. ${ }^{44}$

One consequence of this concern to ensure that an individual be properly tried has been that Article 54 CISA can only operate to benefit the individual who has in fact been judged or his case determined: it cannot benefit those who while involved in the same situation, were not so judged. Its result cannot be applied as a precedent or by analogy to other similar cases. Unlike the operation of mutual recognition in regulatory matters, mutual recognition in the criminal law operates as an individualised principle - applicable only to the individual

\footnotetext{
${ }^{39}$ See Case C-306/09 IB EU:C:2010:626, [2010] ECR I-10341.

${ }^{40}$ Gasparini (n 9).

${ }^{41}$ Case C-469/03 Criminal proceedings against Filomeno Mario Miraglia EU:C:2005:156, [2005] ECR I-2009.

${ }^{42}$ Ibid para 34.

${ }^{43}$ Ibid para 30.

${ }^{44}$ Case C-129/14 PPU Criminal proceedings against Zoran Spasic EU:C:2014:586 para 69.
} 
whose case has been dealt with. In Gasparini while the discontinuation of a case for being time-barred was in fact considered a decision that finally disposed of a case, ${ }^{45}$ the decision could not be applied by analogy to the cases of other individuals involved in the same crime. $^{46}$

The result of interpreting the concept of finality in light of both the principle of free movement and the need to secure justice has been the creation of a single status for individuals. Through an especially strict application of the principle of mutual recognition, applicable in the absence of equivalence and governed solely by the law of the issuing Member State, the Court has been at pains to maximise certainty for the individual, this has been achieved by ensuring that his legal status vis-à-vis that crime is identical throughout the Union. At the same time, as indicated by Gasparini in particular, the Court is anxious to ensure that individuals do in fact face justice and that the principle of ne bis in idem does not operate to allow individuals to evade either being tried or serving their sentence. The result is that a substantive decision relative to that individual must be made. It is an individualised principle. The combination of these two moves has been the creation of a single, individual legal status attaching to individuals.

\section{Interpretation of Sameness in Light of Free Movement A Single Space}

A single individual status, but in relation to what? If the use of a teleological interpretation of the notion of finality in Article 54 CISA has resulted in the creation of a unique legal status for individuals, not governed by multiple legal orders, a similar use of the same teleological interpretation focusing on free movement in defining sameness has resulted in the construction of a single space. It is again the existence of multiple legal orders combined with the need to secure free movement of persons that has determined the choice of the Court of Justice in its interpretation of the principle. In particular it has forced the Court to opt for an interpretation of sameness based on the facts rather than the offense. Sameness for

\footnotetext{
${ }^{45}$ A not uncontroversial conclusion concerning the need to ensure a substantive assessment of the merits of the case. See opinion of AG Sharpston Gasparini (n 9) para 75. Perhaps the decision can be understood as establishing a priority between the two goals contained in Article 54, the need to ensure legal certainty for individuals and the need to ensure that justice be done, with the priority being given to the former where they might conflict such as the present case.

${ }^{46}$ Ibid.
} 
the purposes of Article 54 CISA is to be determined by the essential unity in space and time of the acts of an individual. At the same time, the Court has insisted that this essential unity of factual elements is applied throughout the Union; it is not a concept that operates within a single Member State but extends across the borders of the Union.

A crime is the legal classification of a set of facts, generally the actions combined with the mental state of individuals. It exists by virtue of the law and the existence of a particular crime is the creation of a particular legal system. In other words, a crime is a legal construction of a particular legal system that enters into existence when a set of facts obtain. The ne bis in idem principle has long struggled with this essential duality between law and facts, in defining sameness. On the one hand a legal system might take the view that sameness is defined by reference to the offence: thus a single act may give rise to multiple offenses ${ }^{47}$ and the ne bis in idem principle does not prevent the state from prosecuting an individual for one of those offenses despite a case having been heard and disposed of in relation to another. An alternative approach is to focus not on the definition of the offenses but rather on the facts of the case. Under this approach an individual can only be prosecuted once for any action that resulted in wrong-doing. In this understanding sameness refers to the same act rather than the same crime. ${ }^{48}$

In a national legal system, or an international legal principle that is applied in a national contexts such as the ECHR, the choice of which approach to adopt is open and will depend on the policy decisions and values contained in that particular legal order. In the context of a transnational legal order, one containing a transnational ne bis in idem principle concerned with maximising free movement in a space of multiple legal orders, that choice is quite simply not available. If the legal order wishes that rule to be effective in securing free movement, it must define sameness in terms of facts and not offenses. The reason is clear: a crime is a creature of a legal order and the definition of crimes varies across legal orders. To require that a crime be defined in the same way across Member States in order for the principle to operate (and hence to ensure that individual's enjoy free movement) would be to

\footnotetext{
${ }^{47}$ For example a drunk driver who hits and kills an individual may be guilty of drunk driving, driving recklessly and a form of homicide such as manslaughter; three crimes arising from a single act.

${ }^{48}$ The distinction between offense and act is a little too neat and in reality is likely to be coloured by the fact that facts are needed to substantiate an offense and similarly what facts are precisely relevant will be determined by the legal definition of the offense. Regardless of which approach is adopted it is impossible to exclude considerations of the other element. See van Bockel (n 7) ch 2.
} 
radically reduce its application, if not to render it practically inoperable. In the words of the Court ' $[\mathrm{b}]$ ecause there is no harmonisation of national criminal laws, a criterion based on the legal classification of the acts or on the protected legal interest might create as many barriers to freedom of movement within the Schengen territory as there are penal systems in the Contracting States.' 49

In the place of a definition based on legal classification, the Court has formulated a test based on the 'identity of the material acts, understood in the sense of the existence of a set of concrete circumstances which are inextricably linked together.' ${ }^{50}$ The 'material acts at issue [must] constitute a set of facts that are inextricably linked together in time, in space and by their subject matter. ${ }^{51}$ Thus the legal classification of the offense is irrelevant, to hold otherwise, as indicated in the above quote from Van Straaten, would be to render the right of free movement nugatory. ${ }^{52}$ The legal interest adversely affected by the crime is similarly irrelevant. ${ }^{53}$ Finally, the assessment of 'sameness' is an objective rather than a subjective test - in determining whether acts are the same for the purposes of Article 54 CISA the subjective intention of the accused in relation to the various acts is not to be relied upon, instead an objective assessment of the facts should be undertaken. ${ }^{54}$

Not only has the Court of Justice found that it is the facts, and not the legal classification of those facts, that is at stake in defining sameness under Article 54 CISA but as a consequence of focusing on the facts, the principle can apply to cross-border acts, a possibility that would be excluded by a reliance on the legal classification of the acts. Thus a series of facts that involve the transporting of drugs between Member States are not to be conceived of as two separate offenses of firstly exporting and secondly importing illegal substances but rather may be seen as 'inextricably linked together in time, in space and by their subject-matter' and the same act for the purposes of Article 54 CISA. ${ }^{55}$ This unity in time and space can even operate where there are variations in certain non-essential facts, such as the precise identity of persons involved and quantities of drugs at stake. ${ }^{56}$ What is important is that the

\footnotetext{
${ }^{49}$ Van Esbroeck (n 3) para 34.

${ }^{50}$ Ibid para 36.

${ }^{51}$ Ibid para 38.

52 Ibid.

${ }^{53}$ Case C-288/05 Criminal proceedings against Jürgen Kretzinger EU:C:2007:441, [2007] ECR I-6441.

${ }^{54}$ Kraaijenbrink (n 4).

${ }^{55}$ Van Esbroeck (n 3).

${ }^{56}$ Van Straaten (n 29).
} 
essential unity of the accused's individual act is maintained. Similarly, and even more tellingly, the mere presence of borders and different jurisdictions does not render a single act into multiple acts: an individual convicted of transporting contraband materials across various internal borders of the Schengen area does not as a consequence commit several crimes. ${ }^{57}$ It is an objective assessment of the fact seen in their essential unity, extending across the territory of various Member States, that is relevant, not the differing legal interests represented by the different Member States. ${ }^{58}$

The result of interpreting the sameness criteria in light of the need to secure free movement is therefore twofold. By disregarding the legal classification the Court can ensure that it is the act itself that is at stake and while laws vary across legal orders, facts do not. A single wrongful act can therefore be considered as such across the entire Union. It allows the possibility of understanding a particular wrongful act in unified way across the various Member States of the Union. By focusing on acts rather than offenses the Court has ensured that there is a commonality in terms of the subject matter of the principle: Member States are in effect considering the same thing. Secondly, in concentrating on the facts and in particular ensuring that when considering the essential unity of time and space Member States are not to be limited to the territory of a single Member State, the Court has ensured that the ne bis in idem principle, and the wrongful act of the individual, is one that extends beyond Member States. Borders are irrelevant either in establishing separate crimes of importing and exporting in Van Straaten, ${ }^{59}$ or in establishing multiple instances of the same crime, such as smuggling in Kreitzinger. ${ }^{60}$ The point of reference is not the territory of individual Member States rather the act is to be understood by reference to the Union territory as a whole. It ensures the essential territorial unity of the Area of Freedom, Security and Justice.

\section{Conclusion}

\section{A Multi-Levelled Calling to Account}

We have seen how a strict application of the mutual recognition principle has led to a single status for individuals. Equally the effect of the decision is determined by a single Member

\footnotetext{
${ }^{57} M(\mathrm{n} 13)$.

${ }^{58}$ Kretzinger (n 53) paras 34-36.

${ }^{59}$ Van Straaten (n 29).

${ }^{60}$ Kretzinger (n 53).
} 
State, by necessity the Member State that adopted the decision. The result is a maximisation of the free movement of individuals; not simply between two individual Member States but throughout the Union as a whole: an individual can be convicted in one Member State and move to a second Member State, a third and fourth and so on, secure in the knowledge that the determination of his case by the original Member State will follow him throughout the Union. It mirrors the operation of mutual recognition in citizenship cases securing the autonomy of individuals throughout the Union. ${ }^{61}$ Similarly and in a related fashion the wrongful act of which an individual stands accused is defined according to objective criteria (facts) that are equally applicable throughout the Union. Not only is the subject matter of the trial identical but it is one that operates by reference to the territory of the Union as a whole.

At the same time the Court is anxious to ensure that individuals do in fact face justice. This is evident from Gasparini in which individuals accused of participating in the same crime as Mr Gasparaini were not entitled to rely on the decision to dismiss in his case in order to face justice. In Spasic, interpreting Article 54 CISA in light of the principle contained in Article $52 \mathrm{CFR}^{62}$ the Court found that the need to ensure that individuals do not evade justice rendered the requirement that sentences actually be enforced contained in Article 54 CISA a legitimate exception to the general rule that individuals do not face trial twice. The 'enforced' requirement in Article 54 CISA is therefore a legitimate exception to the right contained in Article 50 CFR. Thus because Mr Spasic had not in fact served the custodial element to his punishment received in Italy, he was liable to face trial for the same acts in Germany. ${ }^{63}$ 'The execution condition laid down in Article 54 CISA is...intended...to prevent, in the area of freedom, security and justice, the impunity of persons definitively convicted and sentences in an EU Member State. ${ }^{64}$ Not to apply the execution condition in this case would mean Article 54 CISA 'would not be sufficient to prevent the impunity of persons definitively convicted and sentenced in the European Union. ${ }^{65}$ Note the interesting shift from the Member States of the European Union to the European Union itself. A combination of these two points - that individuals enjoy a unique status with reference to the EU as a whole and that that individuals do in fact face justice is that individuals enjoy a

\footnotetext{
${ }^{61}$ See for example the 'name cases', chapter 2.

62 Providing for limitations on the rights contained in the Charter subject to certain conditions (necessary, provided for by law and not to affect the essence of the right in question).

${ }^{63}$ Spasic (n 44).

${ }^{64}$ Ibid para 63.

${ }^{65}$ Ibid para 63.
} 
unique status applicable throughout the Union with respect to a particular criminal act. To put it in the words of Duff individuals are properly called to account for their wrongful actions in the European Union.

In a national context the concern is to ensure that an individual is called to account before the national community. It is the national community that one has offended, that has established through its criminal law the particular actions it deems wrongful in light of its own normative code. Indeed as we have seen in cases dealing with expulsion and periods of imprisonment the Court of Justice has subscribed to this communitarian and normative view of crime. ${ }^{66}$ A crime, beyond its immediate victim, is an offence against the community of citizens as a social collective ${ }^{67}$ and it is on the authority of that community that an individual is called to account, tried and indeed punished. Another state punishing an individual for a particular act quite simply does not suffice to answer for the wrong done that community. It is precisely this reason that has made the establishment of a transnational ne bis in idem principle so difficult to achieve and why the taking into account of punishments administered by other states is seen as discretionary.

The relationship between the operation of the ne bis in idem principle and the community of citizens is well illustrated by its operation in federal systems. How a federation deals with the question of ne bis in idem reflects precisely how it envisages the relationship between the different communities of which it is composed. The United States has long operated a doctrine of 'dual sovereignty' when it comes to the application of its double jeopardy rule. Prosecution and indeed punishment for a particular act or crime by a state does not prevent prosecution by the federal authorities. A federal crime is a different thing from a state crime, even if it results from the same act. ${ }^{68}$ An individual is accordingly not protected from being prosecuted separately by federal and state authorities. The ability to punish individuals is a reflection of the sovereign power. 'We have here two sovereignties, deriving power from different sources, capable of dealing with the same subject-matter within the same territory ... Each government in determining what shall be an offense against its peace and

\footnotetext{
${ }^{66}$ See chapter 3.

${ }^{67}$ See also Emile Durkheim, The Division of Labour in Society (George Simpson tr, Collins-MacMillian 1933) chapter 2.

${ }^{68}$ United States v Lanza 260 US 377, 43 SCt 141.
} 
dignity is exercising its own sovereignty, not that of the other. ${ }^{69}$ This power has different origins and is exercised separately by different sovereigns; the state on the one hand and the federation on the other. However, given the division of competences between the two levels of government one might assume that in most cases a direct overlap, thereby creating the possibility of two crimes in two legal orders from one act, would not arise very frequently. Indeed, the dual sovereignty rule could be justified on the basis that the different legal orders play a complementary role, protecting the same general interest in different instances. ${ }^{70}$

This 'interest based' theory is however disproved by considering that dual sovereignty doctrine applies equally between states, ie on a horizontal level. In such a case both states are exercising the same competence within their respective spheres. An application of the dual sovereignty rule in this context implies that where an individual is tried and convicted in one State he can be tried and convicted for precisely the same act in a second State. Just as the federal and state levels reflect different sovereigns, each state represents a different sovereign. 'A State's interest in vindicating its sovereign authority through enforcement of its laws by definition can never be satisfied by another State's enforcement of its own laws...In recognition of this fact, the [US Supreme] Court consistently has endorsed the principle that a single act constitutes an offence against each sovereign who's laws are violated by that act. ${ }^{71}$ While phrased in terms of sovereignty the language of the Supreme Court could easily be translated into Duffian terms. Each sovereign in effect represents a separate community, each of which has the authority to both define what it deems wrongful conduct and to punish individuals accordingly. Two communities, each of which is wronged, reflect two crimes, both of which can be punished. The United States in its understanding of the application of the double jeopardy rule between states thereby reflects a particular view of crime and of the communities that make up its federation.

The exact opposite situation obtains in the European Union with opposite implications for our understanding of its respective communities. Prosecution and punishment in one Member State means prosecution and punishment is impossible in another Member State. An individual is called to account before a national court and, if convicted, is punished by the sovereign power of that Member State. It is certainly an act of wrong-doing against that

\footnotetext{
${ }^{69}$ Ibid 382.

${ }^{70}$ See minority opinion of Brennan J in Heath v Alabama 474 US 82.

${ }^{71}$ Ibid 93 (emphasis in original).
} 
Member State and against the community that Member State embodies. However, the effect of that calling to account is Union-wide, it is valid and applicable throughout the Union visà-vis all Member States.

The result is that where two or more Member States claim jurisdiction, a race to prosecute can arise. $^{72}$ In an attempt to avoid the practical difficulties associated with parallel proceedings, the Union has attempted to institute rules for the coordination of criminal jurisdiction, ${ }^{73}$ in effect formalising the delegation of the calling to account to a single Member State. ${ }^{74}$ However, reflecting the inherent national nature of the process and the sovereign power contained in the right to punish, the Framework Decision on Conflicts of Criminal Jurisdiction merely contains an obligation for consultation between national authorities. It does not establish binding rules allocating jurisdiction. The contrast with the ideas raised by the Commission in its Green Paper on the matter is notable. The Commission proposed certain objective criteria for allocation and even floated the idea of a Union body to eventually resolve conflicts of jurisdiction between national prosecutors, while noting such a move would 'complex questions'. ${ }^{75}$ Such an institution was not created in the final instruments and in fact it was underlined that Member State's would not be obliged to relinquish jurisdiction. ${ }^{76}$ National communities jealously retain the authority to define wrongful behaviour, define when they consider themselves to be wronged and more importantly to call individuals to account for that wrong. ${ }^{77}$

Yet once judged, all other Member States are prevented from prosecuting the same individual for the same act. The result is that crime has been punished, the wrong-doing expunged. It is by implication a single act of wrong-doing with reference to the Union as a whole that has been accounted for. No other acts of wrong-doing against other Member States remain to be punished. The individual Member State is, in addition to acting on its

\footnotetext{
${ }^{72}$ See the case of $M(\mathrm{n} 13)$.

${ }^{73}$ Framework Decision 2009/948/JHA on prevention and settlement of conflicts of exercise of jurisdiction in criminal proceedings [2009] OJ L 328/42.

${ }^{74}$ Not the interesting point raised by the Commission in relation to the operation of an obligation to prosecute that exists in certain Member States. When considering the operation of such a principle in light of a system of coordinating jurisdiction the Commission noted that: 'it can validly be argued that in a common area of Freedom, Security and Justice this principle (the obligation to prosecute) is satisfied when another Member State prosecutes such a case' See European Commission, Green Paper on Conflicts of Jurisdiction and the Principle of ne bis in idem in Criminal Proceedings (COM(2005) 696 final, (2005)) 4.

${ }^{75}$ Conflicts of Jurisdiction in Criminal Proceedings FD 7.

${ }^{76}$ See ibid recital point 11 .

${ }^{77}$ There is however an interesting mediating role for Eurojust in the Framework Decision. See ibid recital point 12 and art 14.
} 
own interests, in a sense, acting on behalf of the Union as a whole. For Lööf this represents a 'regulatory principle' for the system of shared enforcement of criminal law established under the European Arrest Warrant, a system that in turn can only be justified by assuming the Union represents a single social contract as described in chapter $5 .^{78}$ In Duff's words, the Union could be said to be a single community of citizens.

However, the supranational community that emerges is distinctly multi-levelled and indeed paradoxical. It is not quite so simple as assuming a single, supranational social contract as described by Lööf. It is through the wronging of the national community that an individual wrongs the supranational community and it is through the punishment by the national community that the wrong is accounted for. In one sense the crime remains an offense against the national community; it is defined by national law. It is in some sense difficult thus to speak of it as a crime against the whole Union, especially if the act does not represent a crime in all parts of the Union. Yet this is precisely the implication of the transnational ne bis in idem principle. This supranational community has emerged through, and relies on transnational (and therefore ultimately national) process and principles. It is through wronging a national community that one wrongs the supranational community - as it is composed of other communities - and it is through being called to account on a national level that one is called to account supranationally. This national calling to account is transformed through the transnational ne bis in idem principle, interpreted in light of free movement into a supranational calling to account, that in turn reflects a ultimately composite supranational community

of citizens.

\footnotetext{
${ }^{78}$ Robin Lööf, 'Defending Liberty and Structural Integrity: A social contractual analysis of criminal justice in the EU' (PhD thesis, Department of Law, European University Institute 2008).
} 



\section{Chapter 7}

\section{Supranational Public Wrongs}

\section{Introduction}

There are a number of reasons why a community might wish to criminalise certain behaviour and hence deem it wrongful. Firstly, the criminal law can be used to protect and promote a variety of interests, each of different social worth. Criminal law can be seen as a means of maintaining public order in society and in particular maintaining freedom in conditions of security by minimising harmful or risky conduct between individuals. Classic offences against the person, such as assault and murder might be said to fall into this category. Secondly, the criminal law can be seen as a means of expressing the values of a particular society: as an on-going and reflexive process by which society makes manifest and reinforces its collective identity by proscribing conduct that offends against these values. Thirdly, the criminal law may also be used to protect distinctly public goods: collective goods that bring benefit to society as a whole or that are seen as an aspect of the society's collective historical, economic or environmental patrimony, such as the environment, cultural heritage or a proper functioning market. These reasons for criminalisation are distinctive but they are also overlapping and are not mutually exclusive. ${ }^{1}$

Following Duff's account, the unifying characteristic of crimes is that they are public wrongs. They are wrongs shared by the community as a whole and that are experienced by the community, alongside and often through the wrong suffered by the individual citizen. What constitutes wrongful conduct and publically wrongful conduct is an open category, defined by the particular society in which the criminal law operates. It can therefore accommodate all of the above reasons for criminalisation, depending on the context specific definition of wrongness. Acts may be deemed wrongful simply for breaching the shared-

\footnotetext{
${ }^{1}$ See Hart who discusses the multi-valued nature of the criminal law settling on a principal but not exclusive aim of the criminal law as expressing the needs of responsible citizenship with subordinate goals of rehabilitation of the offender (presented as teaching responsibility). See Henry M Hart, 'The Aims of Criminal Law' 23 LCP 401, 401. The rehabilitation of the offender is probably best conceived as a goal of punishment rather than criminal law itself.
} 
morality the community. ${ }^{2}$ Serious harm to individuals may be considered wrongful, made public by its shared quality in which the group is offended on behalf of the individual. ${ }^{3}$ Damage to certain public goods, shared by the community and seen as particularly valuable for intrinsic or instrumental purposes, can be seen as publically wrongful. And while these can also been seen as manifesting a harm principle it is because that harm is deemed a wrong and a wrong against the community that it is criminal. ${ }^{4}$

Up to now we have been considering the case of the treatment of criminal law in transnational processes; the social integration of citizens in other member states and the construction of a single area of justice through mutual recognition instruments. These processes, while giving rise to supranational norms and indeed indirectly reflecting a supranational community, have been based on national substantive criminal law. It is national criminal law that justifies expulsion and national criminal offences that are at stake in both the operation of the EAW FD ${ }^{5}$ and Article 54 CISA. It is the classification of certain acts as wrongful by national communities and offences against those communities that have been at stake. This chapter explores the extent to which EU criminal law is capable of articulating public wrongs on behalf of the Union as a whole and of communicating the wrongful character of those actions (or omissions) to individual citizens. It therefore consists of an analysis as to the capacity of the Union to reflect a supranational community that stands in an independent relationship to individual Union citizens. As crimes are wrongs classified as such by virtue of the particular values and nature of the community, they imply the existence of such a community of shared values. The EU's competence to criminalise, to identify conduct that attracts punishment, has been steadily growing over the past two decades, reaching a certain apogee in the Treaty of Lisbon. Can we therefore say that the EU now has the ability though its criminal law competence, to identify common values and interests and to label them wrongful? Are there such things as European public wrongs and therefore a tentative European community expressed through its criminal law and that calls individual citizens to account for wrongs done to the community and fellow citizens?

\footnotetext{
${ }^{2}$ For the most vocal proponent of this purpose of the criminal law see the discussion of Lord Devlin's views in HLA Hart, Law, Liberty and Morality (OUP 1962).

${ }^{3}$ RA Duff and SE Marshall, 'Criminalization and Sharing Wrongs' (1998) 11 CJLJ 7.

${ }^{4}$ For a discussion of the relationship between the harm principle and his own theory of crimes as public wrongs see RA Duff, Answering for Crime: Responsability and Liability in the Criminal Law (Hart 2007) ch 4.

${ }^{5}$ Council Framework Decision 2002/584/JHA on the European arrest warrant and the surrender procedures between Member States [2002] OJ L 190/1
} 


\section{Structural Limitations on an EU Supranational Community:}

The EU is not a state; its competences are limited in various ways and are exercised in a multi-levelled framework. The first point to be made is that there are key differences between the manner in which the EU exercises its competence to criminalise behaviour and a state's ability to criminalise behaviour. Limitations on the EU's ability to articulate a common supranational definition of wrongful conduct flow from its limited competences and the manner they are exercised. It is a complementary legal order, operating according to a principle of attributed competences and for the most part sharing those competences with Member States. Its authority to act is limited in scope and in its decision making structures, implementation and enforcement it relies on the political processes and legal systems of Member States to complete its work. ${ }^{6}$ This is especially true in the area of criminal law. ${ }^{7}$ These limitations frustrate the ability of the Union to both articulate and especially to communicate the publically wrongful character of particular conduct.

\section{Articulation of Public Wrongs - Limited Scope for EU Criminalisation}

Post-Lisbon the EU has two express legal bases for criminalisation: Article 83(1) TFEU which replaces the old 'third pillar' competence of approximation and Article 83(2) TFEU allowing harmonisation of criminal law in order to better enforce other areas of law that have already been the subject of harmonising legislation at a European level. ${ }^{8}$ In different ways they are restricted in their ability to identify conduct as wrongful; they are limited, ancillary and functional.

\footnotetext{
${ }^{6}$ Luis María Díez-Picazo, 'What does it mean to be a state within the European Union?' [2002] Riv Ital Dir Pubbl Communitario 651.

7 Stephen Coutts, 'The Lisbon Treaty and the Area of Freedom, Security and Justice as an Area of Legal Integration ' (2011) 7 Croatian Yearbook of European Law and Policy 69.

${ }^{8}$ See further ch 1 . Dougan maintains that there remains a residual implicit criminalising competence from the earlier, pre-Lisbon caselaw of Greek Maize, Environmental Crimes and Ship Source Pollution. Michael Dougan, 'From Velvet Glove to the Iron Fist: Criminal Sanctions for the Enforcement of Union Law' in Marise Cremona (ed), Compliance and the Enforcement of EU Law (OUP 2012). However, if such a competence exists, its use is likely to be limited and in practice is largely taken over by the express competence contained in Article 83(2) TFEU. For the purposes of this chapter it is assumed that similar considerations would apply to a residual implicit competence as described by Dougan as apply to the competence contained in Article 83(2) TFEU. There remains the case of Union legislation whose enforcement may or may not be implemented via criminal legislation by Member States. For the purposes of the present discussion that is subsumed into the general regulatory criminal law competence of Article 83(2) TFEU.
} 
The EU's competence to criminalise is first and foremost an unusually limited competence. This does not necessarily prevent the EU articulating common European public interest but it does limit its potential scope. Article 83(1) TFEU is limited both in the existence of certain preconditions and it is further limited by the establishment of a closed list of areas in which the EU may legislate. It provides for legislation only in the case of "particularly serious crime with a cross-border dimension resulting from the nature or impact of such offences or from a special need to combat them on a special basis'. ${ }^{9}$ It is a limited and distinctly complementary role for the European Union dealing with transnational criminal phenomena. ${ }^{10}$ Not content to limit the Union's competence by establishing pre-conditions, the drafters of the Treaty also identified the particular areas that do in fact meet those conditions; in addition to the requirements of transnationality and seriousness, Union action is limited to a closed list of ten areas. The list may be expanded but only by a unanimous decision by Council after obtaining the consent of the European Parliament, the rather burdensome legislative procedure limiting the scope for independent action on behalf of the Union legislator to identify conduct worthy of criminalisation. The competence contained in Article 83(2) TFEU on the other hand is not limited to a closed list of certain areas but is indirectly limited by the precondition of harmonisation in another EU policy area and the condition that criminalisation be necessary for its effective enforcement. ${ }^{11}$

Not only is Article 83(1) TFEU a limited competence, it was traditionally seen as an ancillary competence. Approximation in criminal law was historically justified by the need to secure confidence in a common area of movement. It was thought that diversity in criminal regimes would lead to criminals locating in more lenient jurisdictions, particularly when committing crimes from a distance, such as organised crime or cyber-crime. Such measures were first presented as mere flanking measures, designed to deal with negative side-effects of free movement. ${ }^{12}$ Approximation was seen as a means of preventing 'forum

\footnotetext{
${ }^{9}$ Article 83(1) TFEU.

10 Sometimes termed 'Euro-crimes' in opposition to the Article 83(2) TFEU competence. See European Commission, Towards an EU Criminal Policy: Ensuring the effective implementation of EU policies through criminal law (COM(2011) 573 final, 2011) 5.

${ }^{11}$ See Jacob Öberg, 'Limits to EU powers: A case study on individual criminal sanctions for the enforcement of EU Law' (PhD, European University Institute 2014) and Ester Herlin-Karnell, The Constitutional Dimension of European Criminal Law (Hart 2012) for a discussion on the limitations, potential or otherwise, on the EU's criminalization competence under Art 83(2) TFEU.

12 Anne Weyembergh, 'The Functions of Approximation of Penal Legislation within the European Union' (2005) 12 MJ 149.
} 
shopping' amongst criminals in a new borderless area. ${ }^{13}$ With perhaps more foundation, approximation was also seen as facilitating cooperation between judicial and police agencies in criminal matters. Dealing with common definitions and common offences made joint police investigations and cooperation generally easier. The approximation of criminal law facilitated judicial cooperation by dealing with problems of dual criminality and by helping to establish trust between judiciaries. Indeed, as the criminal law competence of the EU developed, the competence of approximation became distinctly subservient to that of mutual recognition instruments. Mutual recognition began to attract real attention in the Hague Programme ${ }^{14}$ leading to the rolling out of a comprehensive suite of mutual recognition instruments in the following years, beginning with European Arrest Warrant Framework Decision. ${ }^{15}$ Mutual recognition took prime place in the new system of competences in the Treaty of Lisbon while in the Stockholm Programme the hierarchy between mutual recognition and approximation was made explicit: ' $[\mathrm{t}]$ he approximation, where necessary, of substantive and procedural law should facilitate mutual recognition. ${ }^{16}$ Thus the competence granted the EU under Article 83(1) TFEU was not originally envisaged as forming the basis for the Union to assert any autonomous notion of public wrong. It was traditionally viewed as ancillary and subservient to the goal of mutual recognition of national criminal law.

If the Article 83(1) competence is ancillary, the Article 83(2) TFEU contains a distinctly functional criminal competence. While not limited in the same way as Article 83(1) TFEU to a closed list of measures, it is intended above all to be an effective enforcement tool rather than expressive of a wrongful determination by the Union. This distinctly regulatory function of Article 83(2) TFEU crimes can be seen in their evolution. The competence now contained in Article 83(2) TFEU is directly descended from a doctrine designed to ensure the correct implementation of Union law in the context of national procedures. The characterisation of penalties as needing to be 'effective, proportionate and dissuasive' in Greek Maize ${ }^{17}$ the forerunner of Environmental Crimes,${ }^{18}$ is linked to the need for Member

\footnotetext{
13 Ibid164.

${ }^{14}$ The Hague Programme: Strengthening Freedom, Security and Justice in the European Union [2005] OJ C $53 / 1$.

${ }^{15}$ EAW Framework Decision.

16 The Stockholm Programme: An Open and Secure Europe Serving and Protecting Citizens [2010] OJ C $115 / 01,12$. And while not the subject of this chapter the competence to harmonise procedural rules is expressly made ancillary to the functioning of mutual recognition instruments in the Treaty of Lisbon ('to the extent necessary to facilitate mutual recognition of judgments and judicial decisions and police and judicial cooperation in criminal matters'). See Article 82(2) TFEU.

${ }^{17}$ Case 68/88 Commission v Greece (Greek Maize) EU:C:1989:339, [1989] ECR 2965 para 24.
} 
States to ensure that 'infringements of Community law are penalised under conditions, both procedural and substantive, which are analogous to those applicable to infringements of national law of a similar nature and importance and which, in any event, make the penalty effective, proportionate and dissuasive. ${ }^{19}$ As Baker has noted, ${ }^{20}$ this test substantially mirrors the principle of equivalent and effectiveness applied in order to frame the procedural autonomy of Member States when EU law is at stake before national courts. ${ }^{21}$ As with the general doctrines of equivalence and effectiveness in the area of remedies, the reasoning of the Court in Greek Maize is similarly based on the principle of sincere cooperation now contained in Article 4(2) TEU. ${ }^{22}$ And as with remedies, it is above all a question of effectiveness of EU law in the context of national legal systems.

That functional character is now enshrined in the wording of Article 83(2) TFEU which explicitly links its exercise to situations where 'the approximation of criminal laws and regulations of the member States proves essential to ensure the effective implementation of a Union policy in an area that has been subject to harmonisation measures...' It is not a standalone competence but rather is something that complements for the purposes of enforcement another Union policy and goal, be it environmental, financial regulation etc. It is quintessentially regulatory criminal law.

This functional character can also be seen in the operation of the Article 83(2) TFEU competence as discussed by commentators and policymakers. Much discussion on Article 83(2) TFEU has centred on the criteria of necessity and effectiveness as limits to the competence of the Union. ${ }^{23}$ These criteria, vague as they may be, ${ }^{24}$ are seen as expressing the principles of subsidiarity and proportionality in the field of criminal law, essentially regulating the relations and division of powers between the Union and the Member States.

\footnotetext{
${ }^{18}$ Case C-176/03 Commission v Council (Environmental Crimes) EU:C:2005:542, [2005] ECR I-7879.

${ }^{19}$ Greek Maize (n 17) para 24.

${ }^{20}$ Estella Baker, 'Criminal Jurisdiction, the Public Dimension to 'Effective Protection' and the Construction of Community-Citizen Relations' (2001) 4 CYEL 25, 29 ff also making the link with Case C-265/95 Commission v French Republic (Spanish Strawberries) EU:C:1997:595, [1997] ECR I-6959.

${ }^{21}$ See generally Michal Bobek, 'The effects of EU law in the national legal systems' in Catherine Barnard and Steve Peers (eds), European Union Law (OUP 2013) $164 \mathrm{ff.}$

22 'Article 5 of the Treaty (now art 4(2) TEU) requires the Member States to take all measures necessary to guarantee the application and effectiveness of Community law.' Greek Maize (n 17) para 23.

${ }^{23}$ See Herlin-Karnell (n 11) ch 3; Öberg (n 11). For other possible meanings of the term effectiveness in this area see Annika Suominen, 'Effectiveness and Functionality of Substantive EU Criminal Law' (2014) 5 NJECL 388 who speaks of effectiveness in terms of the enforcement of the criminal law.

${ }^{24}$ For a critique of the use of the concept of 'effectiveness' as a competence conferring concept see HerlinKarnell (n 11) ch 4.
} 
However, in addition to the competence question, in their understanding of these criteria, policy makers and commentators have adopted, both implicitly and explicitly, a distinctly functional and moreover utilitarian vision of the criminal law competence contained in Article 83(2) TFEU. It is seen as a policy tool designed to reduce and combat undesirable behaviour through its capacity to deter actual and potential criminals. Deterrence provides the exclusive prism for understanding the criteria contained in Article 83(2) TFEU. And it is deterrence not in furtherance of any independent or intrinsic reason for criminalisation but to enforce an additional, principal, goal. EU action in the field and the adoption of criminal law measures are only deemed to be 'effective' if it ensures compliance with the underlying policy by creating costs for individuals when engaging in the conduct deemed to be prejudicial to the underlying policy. Similarly, they meet the 'necessity' criteria only if other, less onerous forms of sanctioning, such as administrative sanctions, would be incapable of achieving the same result. ${ }^{25}$ It is a utilitarian vision of the criminal law designed, through the application of sanctions and costs for individuals, to reduce harmful activities or promote particular behaviours amongst individuals in order to secure other goals or benefits. It is consequentialist in that it seeks to achieve another aim and is utilitarian in that it does so by means of a cost-benefit understanding of deterrence. ${ }^{26}$

Even the capacity of the criminal law to express social disapproval, an aspect which one imagines would be more closely linked to the forging of a Union wide perspective on wrongfulness and the expressive dimension of criminal law, when it is acknowledged, is framed by the Commission and commentators in terms of its usefulness in deterring individuals; the connotations of social disapproval that come with designating a particular conduct as criminal are primarily seen as another 'cost' imposed on individuals in an attempt to dissuade them from a particular activity. '[C]riminal law sanctions may be chosen when it is considered important to stress strong disapproval in order to ensure deterrence. The entering of convictions in criminal records can have a particular deterrent character.' (emphasis in original ${ }^{27}$ It is viewing the expressive dimension of the criminal law through purely utilitarian lens. The underlying goal of Article 83(2) TFEU, even when social disapproval is invoked, is not primarily to express social disapproval but to ensure better regulatory compliance for another Union policy through the imposition of costs.

\footnotetext{
${ }^{25}$ Commission (n 10) 7-8.

${ }^{26}$ For a discussion of consequentialism and utilitarianism in criminal law theory see Michael Moore, Placing Blame: A Theory of Criminal Law (OUP 1997) 161-163.

${ }^{27}$ Commission (n 10) 11.
} 
The EU's competence to criminalise as found in Articles 83(1) and 83(2) TFEU appears limited in its ability to express the values and hence communal identity of a Union-wide supranational normative community. Article 83(1) TFEU is exceptionally limited and ancillary, limited to so-called 'serious transnational crimes' that necessarily engage a crossborder interest. It is ancillary to national enforcement and has been justified primarily as a side-effect of free movement. To a large extent it could be seen as an institutionalised outgrowth of transnational processes of cross-border movement. Article 83(2) TFEU on the other hand is framed explicitly as a functional competence, parasitic on other Union wide competences. It would appear to exclude the identification of wrongs. Both of these legal bases are limited and linked, in different ways, to other Union activities. Neither allows for a wide ranging ability on the part of the Union to articulate conduct it deems to be wrongful in and of itself, independent of other concerns. And tellingly the question of the EU legislating in the core area of criminal law, those crimes deemed mala in se, has never even been raised; it being accepted uncritically as an area exclusively for the Member States.

\section{Communication of Public Wrongs: EU Criminal Law as Multi-Levelled}

Much of the commentary on the limitations on the EU's competence to criminalise, particularly those contained in Article 83(2) TFEU, has focused on the adequacy or otherwise of those limitations from the point of the constitutional balance between Member States and the Union. ${ }^{28}$ Indeed there appears to be an insistence (no doubt linked to concerns regarding sovereignty) ${ }^{29}$ on the need to retain a distinctly limited role for the Union in this area and a continued focus on the primacy of national actors in the field of criminal justice, not least of all national legislatures and governments. While relevant, the institutional concerns and constitutional balance of powers between the Union and the Member States are not the focus of this chapter. However, they do point to another feature of criminal law in the Union: the necessity of Union criminal law to be mediated by national law. This in turn inhibits the communicative capacity of Union criminal law; to directly communicate to individuals through prohibition of conduct and enforcement of the law, the wrongful character of certain acts and omissions. This is manifested in two points in particular: firstly

\footnotetext{
${ }^{28}$ Jacob Öberg, 'Do we really need criminal sanctions for the enforcement of EU Law?' (2014) 5 NJECL 370.

${ }^{29}$ See Jannemieke Ouwekerk, 'Criminal Justice beyond National Sovereignty. An Alternative Perspective on the Europeanisation of Criminal Law’ (2015) 23 Eur J Crime Crim L \& Crim Just 11.
} 
the inability of EU criminal law to directly establish criminal liability for individuals and secondly, the persistent absence of an EU criminal justice system.

\section{The Union cannot directly impose criminal liability}

The Union cannot itself impose criminal liability and is only capable of adopting directives in order to indirectly criminalise behaviour. ${ }^{30}$ The directive is a multi-levelled instrument par excellence and necessitates implementation by national law. Directives are binding on Member States but cannot bind individuals with the result that the enactment of national law is required before individuals are subject to any obligations. This fact is well known and has been applied in the case of criminal law for some decades now. In Pretore di Salo the Court stated that the directive in question 'cannot, of itself and independently of a national law adopted by a Member State for its implementation, have the effect of determining or aggravating the liability in criminal law of persons who act in contravention of the provisions of that directive. ${ }^{, 31}$ This reasoning was explicitly based on the Court's prior jurisprudence on the absence of direct effect of directives. ${ }^{32}$ The subsequent evolution of the caselaw on the imposition of criminal liability by the Union has revealed a fundamental inability on the part of the Union to by itself create criminal liability.

The straightforward application of the inability of directives to directly impose liability on individuals has evolved into a general principle that Union law cannot aggravate the criminal liability of individuals. Unlike in other areas of law, the indirect effect of directives has been explicitly set aside in the area of criminal liability. Thus in Kolpinghuis the Court accepted that the principle of sincere cooperation would normally imply a duty of conform interpretation and an obligation to interpret national law in light of Union law. However, if the fulfilment of such a duty led to the aggravation of criminal liability, its application would have to be set aside. ${ }^{33}$ In contrast to Pretore di Salo, the judgment in Kolpinghuis was based not only on the nature of directives, but also from the general principles of Union law and in

\footnotetext{
${ }^{30}$ Under Article 83 TFEU the Union may only adopt directives. Thus under Article 83(1) TFEU 'the European Parliament and the Council may, by means of directives adopted in accordance with the ordinary legislative procedure...' (emphasis added). Similarly under Article 83(2) 'if the approximation of criminal laws and regulations of the member States proves essential to ensure the effective implementation of a Union policy...directives may establish minimum rules' (emphasis added).

${ }^{31}$ Case 14/86 Pretore di Salò EU:C:1987:275, [1987] ECR 2545 para 20.

${ }^{32}$ Ibid para 19.

33 Applied similarly in the case of Framework Decisions see Case C-105/03 Criminal Proceedings against Maria Pupino EU:C:2005:386, [2005] ECR I-5309.
} 
particular the principle of legality and non-retroactivity of criminal law. This move from an argument based on the lack of direct effect to one based on general principles allowed the Court subsequently to extend the principle to regulations, at least those requiring some degree of national implementing measures. In $X$ the Court accepted that while the principle of conform interpretation would apply to create possible civil remedies (and by implication obligations) it could not operate to impose criminal obligations in the absence of national implementing legislation. ${ }^{34}$

That the Union legal order recognises the principle of legality is not in and of itself particularly controversial and indeed is to be welcomed. However, the real question at stake in the caselaw is not whether criminal liability should be laid down in a legal instrument validly adopted - i.e. that it should enjoy the quality of 'legality' - but rather which level of a multi-levelled legal order is competent to do so - i.e. the question is whose legality.

The implicit answer flowing from the jurisprudence that the principle of legality operates at the national level. ${ }^{35}$ Mere adoption by the Union of measures criminalising conduct is not sufficient to meet the requisite standard of legality. Union law in the criminal field quite simply does not enjoy that quality. This deficiency is revealed by the contrasting reasoning and conclusions reached by the Advocate General and the Court in Berlusconi. ${ }^{36}$ Advocate General Kokott found that the offending piece of national legislation rendered a situation that was previously in compliance with Union law into a situation that breached Union law and should therefore be set aside, leaving the original, more stringent, regime in place. According to the Advocate General, the principle of the retroactive application of the more lenient criminal sanction or regime was not relevant. That principle applied in order to allow an individual to benefit from an altered assessment of the conduct on the part of the legislature. However, in the Advocate General's opinion the legislature had not in fact altered its opinion because the relevant legislature was the Union legislature. ${ }^{37}$ The Court on the other hand, applied the principle of the application of the more lenient sanction. The subsequent national measure did breach Union law, but was not set aside as in normal

\footnotetext{
${ }^{34}$ Case C-60/02 Criminal Proceedings against X EU:C:2004:10, [2004] ECR I-651.

${ }^{35}$ It will be noted that this is consistent with the finding of both the AG and the Court regarding the principle of legality in the challenge to the European Arrest Warrant Framework Decision. See Case C-303/05 Advocaten voor de Wereld VZW v Leden van de Ministerraad EU:C:2007:261, [2007] ECR I-3633.

${ }^{36}$ Joined Cases C-387/02, C-391/02 and C-403/02 Criminal Proceedings against Silvio Berlusconi, Sergio Adelchi and Marcello Dull'Utri et al EU:C:2005:270, [2005] ECR I-3565.

${ }^{37}$ Ibid Opinion of AG Kokott paras 61-62.
} 
circumstances it should be. The Court's reasoning was largely based on the nature of the directive and its inability to bind individuals or impose obligations. In this sense it marks an interesting return to the classic 'direct effect' reasoning of Pretore di Salo. ${ }^{38}$ But considering it in light of the AG's reasoning, implicit in the Court's rather technical judgment is the fact that it is not the Union legislature that ultimately imposes criminal liability. It is an affirmation of the multi-levelled nature of the process of criminalisation in the Union legal order and the inability of the Union legislature to identify offending conduct that would bind individuals directly or even indirectly. Any imposition of criminal liability must be mediated by national law. ${ }^{39}$

The principle of legality retains a place in Union law but it is an indirect legality mediated by national law. In fact, the concern of the Union that when criminalising conduct as a consequence of Union law the principle of legality is respected, is reflected in a preference for legislation, rather than regulations or other administrative measures, at a national level when criminal sanctions are at stake. ${ }^{40}$ The principle of institutional autonomy that might otherwise apply is attenuated to some extent by the general principles of Union law and in particular the principle of legality. Legality does exist and is to a certain extent mandated by the Union legal order, but at the national level.

The general principle that appears to have emerged, that Union law cannot aggravate criminal liability is true, but is not the whole truth. The truth is that Union law cannot even create criminal liability for individuals. Criminal law must enjoy a certain quality of 'legality', adopted by a competent and legitimate legislature, in a sufficiently clear manner and enjoy such legality at the time of the offending conduct. But that process, by which an offence acquires that quality of legality, takes place at a national level; not at the Union level. Thus the accusations sometimes levelled at Union instruments for being too vague ${ }^{41}$

\footnotetext{
${ }^{38}$ Pretore di Salò (n 31).

${ }^{39}$ Dougan (n 8).

40 See Loïc Azoulai, 'La loi et le règlement vus du droit communautaire' (2006) 19 Cahiers du Conseil constitutional, 6 citing the example of Criminal Proceedings against X (n 34) at para 61.

${ }^{41}$ See Cian Murphy, EU Counter-Terrorism Law: Pre-Emption and the Rule of Law (Hart Publishing 2012$) 51$ specifically in relation to the Framework Decision on Combating Terrorism. 'the FDCT [Framework Decision on Combatting Terrorism] has resulted in broad legal rules that run contrary to the principle of legality.' Similarly, accusations that vagueness in the definition of the Union's competence, cited in relation to the effectiveness criteria under Article 83(2) TFEU, as breaching the principle of legality (See Perrine Simon, 'The Criminalisation Power of the European Union after Lisbon and the Principle of Democratic Legitimacy' (2012) 3 NJECL 242) are similarly misplaced; it is not the competence of the enacting legislative body that must be
} 
and hence breaching the principle of legality miss the mark. The Union instrument is not the legal instrument that renders the conduct criminal. It is the national implementing legislation that definitively binds the individual and it is that legislation that must conform to the principle of legality. ${ }^{42}$

\section{Operating within national criminal justice systems}

The systemic nature of the criminal justice system is one that is often raised both in general discussions on criminal law. ${ }^{43}$ Criminal justice involves a variety of actors and institutions, at different stages of the process and with varying levels of discretion. ${ }^{44}$ Putative criminal acts need to be defined, detected, enforced, judged and sanctions applied, all in a context that respects the rights of the accused and the need for an effective and fair process. The legislature, the police, prosecutors, the judiciary, prison services and probationary bodies are all involved. Various aspects of the system interact, complementing and compensating for each other; obligations to prosecute may be alleviated by greater discretion in relation to conviction; a lesser degree of detection and prosecution may be compensated by a higher sanction and so on.

There is no EU criminal justice system in the proper sense. EU criminal law is applied in the context of national criminal justice systems and must take account of their particular features and characteristics that are generally a product of divergent and distinct historical experiences. There is a distinct absence of an institutional structure for the enforcement of substantive EU criminal law. There are no EU prosecutors (to date), police, criminal courts or prisons. Eurojust and Europol perform coordinating roles amongst national and prosecutorial authorities in order to share information and facilitate cooperation and coordination in cross-border instances. ${ }^{45}$ The one example of a putative supranational criminal justice institution with competence to prosecute, the European Public Prosecutors

precisely defined (indeed national legislatures are subject to far fewer constraints on their ability to criminalise behaviour) but the obligations imposed on individuals at any given time.

${ }^{42}$ Note that this is echoed in the Court's pronouncement on the application of the principle of legality in the context of European Arrest Warrant proceedings; legality is assured not by the quality of the European Arrest Warrant Framework Decision but rather by the national legislation of the issuing Member State. See Advocaten voor de Wereld (n 35) para 52. See discussion in chapter 5.

${ }^{43}$ For a treatment of the criminal justice system as such see Lucia Zedner, Criminal Justice (OUP 2004).

${ }^{44}$ See a related discussion of the concept of effectiveness in the context of multiple national systems by Suominen (n 23).

${ }^{45}$ See Valsamis Mitsilegas, EU Criminal Law (Hart 2009) ch 4. 
Office (EPPO), has met with significant resistance from national parliaments, with complaints raised in the context of the Early Warning Mechanism. ${ }^{46}$ Above all there is no EU trial. For Duff the trial was the central forum in which the individual was called to account before his or her fellow citizens. It was a public and communicative process involving a rule-governed and symbolically loaded dialogue between the different parties determining and assessing the wrong to the community and an opportunity for the accused to defend or justify his actions. ${ }^{47}$ It is the forum through which individuals as citizens answer for their potentially wrongful conduct before the public community. ${ }^{48}$

Similarly EU law only specifies the punishment to a certain extent and certainly does not enforce the punishment of any individual, be it custodial, monetary or some form of alternative sanction. Under the old Environmental Crimes jurisprudence the competence to specify sanctions was explicitly denied the then Community ${ }^{49}$ whereas under the old third pillar sanctions were imposed but were of a minimum nature, typically providing for a minimum-maximum sentence (the so-called min-max solution) in order to facilitate the operation of mutual recognition instruments. ${ }^{50}$ While there have been some efforts at developing a sanctioning policy, ${ }^{51}$ sanctioning still remains to a large extent the purview of the national legal system and subject to their various systems and must operate within that system leading to potential variations in their elaboration and enforcement through prison and probation authorities. ${ }^{52}$ Of course, the Union generally lacks an enforcement capacity

\footnotetext{
46 Proposal for a Council Regulation on the establishment of the European Public Prosecutor's Office $\operatorname{COM}(2013) 534$ final. Complaints focused on the potential for competence creep and in particular the EPPO's ability to prosecute for related national offences. See Vanessa Franssen, 'National Parliaments issue yellow card against the European Public Prosecutor's Office' (European Law Blog, 4 November 2013) $<$ http://europeanlawblog.eu/?p=2025> accessed 20 July 2015.

${ }^{47}$ RA Duff, Punishment, Communication and Community (OUP 2003).

${ }^{48}$ See Duff, Answering for Crime: Responsability and Liability in the Criminal Law (n 4) ch 8. See also Duff, Punishment, Communication and Community (n 47) 80.

${ }^{49}$ Since remedied by the Treaty of Lisbon. See Article 83(2) TFEU. See also the concerns of AG Mazak arguing against the ability of the Union to specify sanctions in Ship Source Pollution raising the issue of the consistency of each national penal system. See Case C-440/05 Commission v Council (Ship Source Pollution) EU:C:2007:625, [2007] ECR I-9097 Opinion of AG Mazak para 104.

${ }^{50}$ Although indirectly this activity does declare a certain common consideration of the seriousness of these acts.

${ }^{51}$ See Steve Peers, EU Justice and Home Affairs Law (3 edn, OUP 2011) $803 \mathrm{ff}$.

${ }^{52}$ The problematic nature of this situation has indeed been acknowledged by the European Commission in considering the effectiveness of Union criminal law, noting that simply defining the different components of offences is not sufficient but rather that similar attention needs to be paid to detection, prosecution rules, the levels and indeed the application of sanctions. At the same time the Commission is aware of the diversity and peculiarities of national legal systems: '...the penalty served is ultimately the result of a complex equation involving an extremely large number of variables: theoretically action would have to be taken on every one of them to guarantee an identical penalty in all the legal orders... [however] the differences between the Member States' legislation on penalties are still quite sharp. There are historical cultural and legal reasons for this, deeply-rooted in their legal systems, which have evolved over time and are the expression of the way in which
} 
and always relies on national agencies and institutions to ensure all Union law is applied. The Union is not a state and lacks core features of the state, including the ability to exercise force. For this it relies on the Member States. ${ }^{53}$ However, the enforcement of a particular sanction and the infliction of 'hard treatment' in the furtherance of expressing disapproval is particularly important in the context of criminal law. The very purpose of the criminal law as a communicative exercise is embodied in the application and the imposition of sanctions. Indeed, it is this feature that for some scholars defines criminal law. ${ }^{54}$ As with the trial, the sanction is a vital component of the expressive dimension of the criminal law. It is through the sanction and in particular the imposition of 'hard treatment' 55 that the community communicates its moral disapprobation, underlines the wrong it considers has been done both to the individual victim and the community as a whole and facilitates the reform, reconciliation and repentance of the offender through a system of secular penance. ${ }^{56}$ As part of a multi-level system that is necessarily mediated by national law, Union law expressly (and for good reasons) does not have capacity to engage in a meaningful communicative activity with wrong-doers directly. For all the talk of the Commission of criminal sanctions demonstrating 'social-disapproval' this is only very weakly manifested and communicated to the accused and sentenced as social disapproval of a supranational community at Union level. The individual is not called to account within a European forum, instead it is before a national court, representing the national community that he or she is judged and censure pronounced.

A number of points have been made thus far pointing out the limitations on the capacity for the Union through its criminal law to articulate and communicate public wrongs at a supranational level. Firstly, the competences of the Union are necessarily limited, thus limiting its scope. More importantly, these competences are limited in such as way such as to

\footnotetext{
Member States have faced and answered fundamental questions about criminal law. These systems have their own internal coherence, and amending individual rues without regard for the overall picture would risk generating distortions.' European Commission, Green Paper on the approximation, mutual recognition and enforcement of criminal sanctions in the European Union (COM(2004) 334 final Brussels, 2004) 8.

53 Díez-Picazo (n 6) 657 discussing the application of Union law in the context of national institutional autonomy.

${ }^{54}$ Joel Feinberg, 'The Expressive Function of Punishment' (1965) 49 The Monist 397.

${ }^{55}$ See Duff, Punishment, Communication and Community (n 47) 82.

56 Ibid 106. Furthermore, at least for the moment, society appears to consider that the imposition of hard treatment and in particular imprisonment is perhaps the only adequate means of expressing social disapproval commensurate with the criminal law. See Richard H McAdams, The Expressive Powers of Law: Theories and Limits (Harvard UP 2015) 178-179 discussing an empirical study conducted by Dan Kahn entitled 'What do alternative sanctions mean?' Respondents appeared not to value fines or community service as sufficiently conveying social disapproval.
} 
restrict the expression of autonomously supranationally determined public wrongs. Article 83(1) TFEU is an ancillary competence whereas Article 83(2) TFEU only provides for functional criminalisation. It would appear that the role of the European Union in specifying acts which it considers to be intrinsically wrong is limited. Secondly, it was pointed out that the multi-levelled nature of the EU criminal justice system militates against it representing for individuals an autonomous supranational disapproval of particular actions. Flowing originally from the nature of the directive but since relying on the principle of legality, it would appear that the Union for all its being a Union of peoples, quite simply cannot independently impose criminal liability on individuals. The prized feature of direct effect, creating a direct link with individuals, does not operate in the field of criminal law. In a related sense, the mediation of criminal law by national legal systems and institutions, ${ }^{57}$ stymies the normal communicative function of the criminal law in expressing disapproval for particular conduct on behalf of the community through trial and punishment.

\section{Emergence of a Supranational Identity}

The competences of the EU in substantive criminal law are limited and instrumental. Nonetheless, one cannot deny that it is criminal law and necessarily performs an expressive function. ${ }^{58} \mathrm{EU}$ criminal law is limited both in its scope and its structure in articulating public wrongs, but it is not entirely devoid of such a capacity. Behind the structural limitations imposed on the Union both in its regulatory competence, now found in Article 83(2) TFEU, and its 'Eurocrimes' competence found in Article 83(1) TFEU, lies an ability, limited and indirect, to identify certain acts or conduct deemed wrongful by the Union and hence to give expression to certain values and normative choices.

\footnotetext{
${ }^{57}$ See Dougan (n 8) and Estella Baker, 'Governing through Crime - the Case of the European Union' (2010) 7 European Journal of Criminology 187 on this point.

${ }^{58}$ This would be in McAdam's taxonomy an 'expressive-politics' theory of law ie that (certain) law expresses certain political values or messages. Other theories of the expressive dimension of law would be expressive theories of laws effects whereby the law communicates and by that communication alters the behaviour of people (the subject of McAdams' study); normative theories of expressive law, where by the expressive quality of law has implications for how it should be use and finally normative theories of expressive conduct, in which conduct that expresses certain sentiments or values should be regulated by the law in a particular way. See McAdams (n 56) 13-16.
} 


\section{European Public Goods}

It is perfectly open to a society to consider respect and protection for certain public goods of the community as elements of its normative code, the breach of which constitutes not simply a harm but a wrong against the community (albeit it a wrong by virtue of the harm). Indeed for Duff 'wrongful violations of public goods seem to be strong candidates for criminalisation'. ${ }^{59}$ This purpose, while linked, exists alongside the purely functional or instrumental view of the criminal law. Criminal law may be seen as a deterrent and perform an ancillary role of preventing and minimising harm to a collective good. However, that is not its primary goal and indeed other forms of regulatory law may more effective in this regard. ${ }^{60}$ Rather it is intended to express the moral condemnation of the community for the violation of a public good. It is to identify certain interests of the community, damage or harm to which constitutes a wrong against the community and to call individual citizens to account for that harm or damage. ${ }^{61}$

EU law identifies a number of public goods the violation of which constitutes a crime and therefore a wrong. Most obviously in Environmental Crimes the Court of Justice highlighted the specificity of the environment as an objective of the EU as one that is particularly important and transversal: '[I]n the words of Article 6 EC "[e]nvironmental protection requirements must be integrated into the definition and implementation of the Community policies and activities", a provision which emphasises the fundamental nature of that objective and its extension across the range of those policies and activities' ${ }^{62}$ The

\footnotetext{
${ }^{59}$ Duff, Answering for Crime: Responsability and Liability in the Criminal Law (n 4) 126.

60 Ibid 87.

${ }^{61}$ Thus Öberg's claim, reflected in the Commission's own communications, that before the Union exercise its competence under Article 83(2) TFEU it must first demonstrate through an impact assessment the effectiveness of criminal law in reducing harm or ensuring compliance misunderstands the nature of criminal law as distinct from regulatory law. Criminal law's primary purpose is not to ensure compliance (although this may be a useful added benefit) but to declare and punish wrong-doing. It involves a fundamentally different purpose. See Öberg, 'Do we really need criminal sanctions for the enforcement of EU Law?' (n 28) 347-376. Adopting a moralist view of the criminal law does raise the question of the appropriateness of including terms such as 'essential' and 'effective implementation' in the text of Article 83(2) TFEU or indeed the conceptual coherence of Article 83(2) TFEU which seems to ignore completely (or at least sideline) the distinctive character of criminal law.

${ }^{62}$ Environmental Crimes (n 18) para 42. Indeed one of the main concerns of commentators following Environmental Crimes was whether it was in fact, by virtue of the importance of the policy are, limited to the environment, or whether the new competence extended beyond to other areas of Union action. Ship Source Pollution, did little to clarify this question, which, while in theory being a policy based on transport policy, had clear overlaps with the environment, a fact that was highlighted by the Court of Justice when identifying the framework decision in question as relating to 'conduct which is likely to cause particularly serious environmental damage...' See Ship Source Pollution (n 49) para 67. See Steve Peers, 'The European Community's Criminal Law Competence: The Plot Thickens' (2008) 33 EL Rev 399, 406 and Peers, EU Justice and Home Affairs Law (n 51) 773.
} 
specifically public and collective nature of the environment as a good was highlighted by AG Ruiz-Jarabo Colomer: '[t]here thus emerges a right to enjoy an acceptable environment, not so much on the part of the individual as such, but as a member of a group, in which the individual shares common social interests. ${ }^{63}$ A number of other European public goods can be identified alongside the environment the violation of which constitutes a wrong. Baker has noted the internal market has been identified as a public good to be protected (at least implicitly) by criminal law. ${ }^{64}$ Unlike in the case of Greek Maize, ${ }^{65}$ in Spanish Strawberries ${ }^{66}$ the Court was concerned not just with the rights of individuals but the collective interests of the then Community. ${ }^{67}$ The protests of farmers and the inaction of the state authorities was framed as a threat not simply to the importers directly concerned but as threatening the 'integrity' of the market and its future availability to the Community as a whole to whom it belonged as 'a collective asset'. ${ }^{68}$ Thus Member States were obliged to ensure, through their criminal justice system, that this collective asset was protected and preserved. Related to the internal market, the financial system is also a concern of EU criminal law with a recent Directive adopted mandating specific and tough sanctions for market abuse. ${ }^{69}$ On various occasions in legislation ${ }^{70}$ and caselaw ${ }^{71}$ the need to protect the 'integrity' of the financial system has been stressed and is now protected by criminal law. The financial resources of the Union is another public good protected by criminal law, ${ }^{72}$ complete with a proposed EU institution to prosecute such fraud. ${ }^{73}$ Currency, and in particular the Euro, is also a good

\footnotetext{
${ }^{63}$ See Environmental Crimes (n 18) Opinion of AG Ruiz-Jarabo Colomer para 67.

${ }^{64}$ Baker, 'Criminal Jurisdiction, the Public Dimension to 'Effective Protection' and the Construction of Community-Citizen Relations' (n 20).

${ }^{65}$ Greek Maize (n 17).

${ }^{66}$ Spanish Strawberries (n 20).

${ }^{67}$ Baker, 'Criminal Jurisdiction, the Public Dimension to 'Effective Protection' and the Construction of Community-Citizen Relations'(n 20)

68 'The vandalism also had the potential adversely to affect other traders with a stake in the Single market and, on the basis that the latter's fundamental purpose is to enhance prosperity across the Union, ultimately to damage the interest of EU citizens in general to whom it belongs as a collective asset.' ibid 41.

${ }^{69}$ Directive 2014/57/EU on criminal sanctions for market abuse [2014] OJ L 173/179. See in particular the preamble and art 1(1). See also Framework Decision 2003/568/JHA on combating corruption in the private sector [2003] OJ L 192/54 that in its preamble speaks of the threat posed by such corruption to 'law abiding society as well as distorting competition....and impeding sound economic development' (point 9 of preamble).

${ }^{70}$ Market Abuse Directive (n 69).

${ }^{71}$ See Case C-45/08 Spector Photo Group v Commissie voor het Bank-, Financie en Assuranctiewezen (CBFA) EU:C:2009:806, [2009] ECR I-12073.

${ }^{72}$ Proposal for a Directive on the fight against fraud to the Union's financial interests by means of criminal law $\operatorname{COM}(2012) 363$ final. Indeed, in a different context, it was the direct implication of the Union's own resources that triggered the application of the Charter of Fundamental Rights in Case C-617/10 Aklagaren v Hans Akerberg Fransson EU:C:2013:280.

${ }_{73}$ Proposal for a Council Regulation on the establishment of the European Public Prosecutor's Office $\operatorname{COM}(2013) 534$ final. Although note the resistances of national parliaments to the Commission's proposal indicated above.
} 
protected by supranational criminal law. ${ }^{74}$ Finally, the provision of security itself and the wide range of measures that have been adopted and in particular the constitution of the EU as a 'secure space ${ }^{75}$ can be seen as a public good 'offered' to the citizens of the Union. ${ }^{76}$

While there is no explicit pronouncement that definitively identifies the criteria the Union uses to identify public goods worthy of protection by criminal law it would appear that the examples identified above fall into two categories. ${ }^{77}$ On the one hand there is the simple category of classic public goods corresponding to policy domains that have (to varying extent) been appropriated by the Union either through a functionalist spill-over effect or in its quest to secure output legitimacy. Under these criteria a clean environment and public security would be considered public goods par excellence. In the language of economists they are non-excludable (individuals cannot be excluded from their enjoyment) and nonrivalous (the use by one individual does not diminish its use by another). ${ }^{78}$ These qualities mean they typically will not be provided by private market operators and must therefore be provided by the public, in this case the European Union. In these areas the EU represents a typical public authority ensuring the protection of a classic public good.

The other group of public goods identified above are similarly public goods in the economic sense of being non-excludable and non-rivalous but have an additional quality that appears to be linked more specifically to the nature of the Union itself as a polity and which explains the particular language used by the Court and the legislature in identifying them. Those other public goods appear to be more clearly associated with the Union's traditional vocation of generating prosperity through creating market institutions at a European level; the internal market itself, the financial system and the currency. These are institutional facts constructed by Union law. ${ }^{79}$ These European-wide market institutions are systems of rules that govern market participation by individuals in such a way as to secure prosperity. Their protection lies specifically in the maintenance of the 'integrity' of the body of rules that constitute the

\footnotetext{
${ }^{74}$ Directive 2014/62/EU on the proctection of the euro and other currencies against counterfeiting by criminal law and replacing Framework Decision 2000/383/JHA [2014] OJ L 151/1.

${ }^{75}$ Patrick Twomey, 'Construcuting a Secure Space: The Area of Freedom, Security and Justice' in David O'Keefe and Patrick Twomey (eds), Legal Issues of the Amsterdam Treaty (Hart 1999).

${ }^{76}$ For security as a public good see Ian Loader and Neil Walker, Civilising Security (CUP 2007) ch 6.

${ }^{77}$ With the exception of the Union's own financial resources which would appear to be a public good in the most literal sense.

${ }^{78}$ For a description of the classic account of public goods produced by economist Mancur Olsen see Alun Howard Gibbs, Constitutional Life and Europe's Area of Freedom, Security and Justice (Ashgate 2011) 48.

${ }^{79}$ See Neil MacCormick, 'Law as Institutional Fact' 90 LQR 102.
} 
institutional fact. Similarly, in the case of currency counterfeiting the Union is specifically concerned with ensuring 'trust in the genuine character' of the currency. ${ }^{80}$ Hence the references to the systemic nature of these particular 'public goods' by both the legislation itself and the Court.

The Union has not simply identified certain public goods worthy of protection but has, by insisting on the use of criminal rather than civil law, indicated that it views an attempt to undermine or cause harm to such goods as wrongful in a public sense i.e. an offense against the community. While much of the discussion on the use of the criminal law has focused on the utilitarian and instrumental purpose in enforcing EU objectives there are some indications that the Union institutions are aware of the condemnatory function of the criminal law and are anxious to use the criminal law for this precise purpose. Behind much of the struggle over competence in the Environmental Crimes saga lay the ability of the Community itself (now Union) to prescribe criminal law measures rather than rely on the traditional formula of 'effective and equivalent' measures and leave the decision to criminalise in the hands of Member State governments. While for the most part emphasising the instrumental nature of these measures as deterrents, the Commission has not been ignorant of the condemnation and social disapproval that is communicated via criminal law ${ }^{81}$ and in its arguments before the Court in Ship Source Pollution it stressed the fact that the conduct concerned 'must be regarded as reprehensible' and hence requiring criminal rather than civil sanctions. ${ }^{82}$ Similarly, AG Mazak described the criminal law as 'a barometer of the importance attached by a community to a legal good or value'. ${ }^{83}$

By insisting on the competence of the Union to criminalise such conduct EU law is by implication identifying certain public goods as European public goods, harm to which constitute a European public wrong. In Ship Source Pollution the AG stressed the fact that '[i]t must be recalled that upholding Community (now Union) law is the responsibility of the

\footnotetext{
${ }^{80}$ Counterfeiting Directive (n 74) recital 15.

${ }^{81}$ See Commission, Towards an EU Criminal Policy: Ensuring the effective implementation of EU policies through criminal law (n 10) 11.

${ }^{82}$ Ship Source Pollution (n 49) para 31.

${ }^{83}$ Ibid Opinion of AG Mazak para 95. See also the comments of AG Ruiz Jarabo-Colomer in Environmental Crimes (n 18) noting that 'in academic thinking a degree of consensus has emerged that ecosystems should be regarded as particularly important legal interests, and that their protection is vital for the very existence of humankind, with the consequence that their conservation and maintenance fully justify the intervention of criminal law with a specific safeguard...the ethical dimension of criminal punishment must not be overlooked. When an act is sanctioned in criminal terms, it is held to merit the most severe reproach because it transgresses the fundamental tenets of the legal system.' (Opinion of AG Ruiz Jarano-Colomer paras 73-74.)
} 
Community (now Union) institutions....if the legal interests protected in such offences were one of the objectives of the Community (now Union), no one would dispute the ability of its law-making bodies to require the Member States to prosecute in criminal law. ${ }^{84}$ In a somewhat different context in Akerberg Fransson it was the Union's interest in the protection of its own resources and the treaty obligation placed on Member States to ensure their protection that rendered it a matter of EU law thereby ensuring the application of the Charter of Fundamental Rights to the criminal proceedings in question. ${ }^{85}$

Behind the competence question and specifically the ability of the Union to prescribe criminal sanctions as a means of the effective enforcement of a Union objective or policy lies the ability of the Union itself to identify European public goods, harm to which constitutes a European public wrong and indirectly manifest a European community. For Duff the condition that a wrong be public before it be criminalised does not by itself provide the content of the criminal law. Rather it simply indicates that the precise content will vary depending on the community involved, its purpose, norms and values. What is public is therefore is context and norm specific. ${ }^{86}$ For the Union, threatening the integrity of market institutions would appear to be particularly strong candidates for public wrongs, indicating that for the Union at least, the market and its attendant rules and systems are a public good worthy of respect. By declaring an act criminal, the community is declaring what wrongs are considered public in accordance with its particular principles and values. By insisting that the Union declare such conduct criminal it is implying that the community for whom it is a public concern is the Union itself.

\section{European Public Values}

All law involves valuation; a judgement of how we stand in relation to acts, relationships and objects. ${ }^{87}$ The criminal law is the judgment of the community of certain acts, or in more limited cases omissions, it deems to be publically wrongful. It therefore involves an assessment of conduct according to its wrongfulness and necessarily involves a normative

\footnotetext{
${ }^{84}$ Environmental Crimes (n 18) paras 49-50.

${ }^{85} \AA$ Åkerberg (n 72).

${ }^{86}$ Duff, Answering for Crime: Responsability and Liability in the Criminal Law (n 4) 142.

${ }^{87}$ Cass Sustein, 'Incommensurability and Valuation in Law' (1994) 92 Mich L Rev 779, 783 speaking of "kinds of valuation"; "the term is meant to draw attention to our diverse stances towards relationships or prospects or to the disparate theories of valuation through which we conceive and evaluate relationships, events or prospects. Every kind of valuation embodies a qualitatively distinctive judgment or response.'
} 
valuation of that act. While Article 83(1) TFEU has been justified primarily in terms of its ancillary role in facilitating mutual recognition and police and judicial cooperation in a space of free movement, it cannot entirely efface the valuative or expressive character of declaring a particular act or activity criminal. Indeed, for some areas of activity it would appear to be the principal function of the Union's legislative activity.

Turner has described in detail the expressive nature of the Framework Decision on Combating Racism and Xenophobia. ${ }^{88}$ She has demonstrated conclusively that the ostensible justifications for the measure in harmonising national legislation to facilitate judicial cooperation are either not achieved or unnecessary, particularly following the abolition of double criminality requirements for the majority of mutual recognition instruments and in particular the EAW FD. ${ }^{89}$ The preparatory legislative documents contain various assertions of the particular values of the Union, in particular democracy, the rule of law and nondiscrimination, and how these in fact motivate and inform the legislation. ${ }^{90}$ These values make their way into the preamble of the framework decision that speaks of the principles of 'liberty, democracy, respect for human rights and fundamental freedoms and the rule of law, principles upon which the European Union is founded and which are common to the Member States. ${ }^{91}$ Indeed, given the failure to harmonise the most contentious aspect of racist speech - holocaust denial - and the failure to impose any requirements of enforcement and prosecution, its practical impact either as a harmonising instrument or an enforcement tool at a national level is likely to limited, ${ }^{92}$ leading to the conclusion that 'the expressive value of the Framework Decision is greater than its practical impact...[and that]...the European Union is using the Framework Decision primarily to make a statement about the values for which it stands. ${ }^{93}$

\footnotetext{
${ }^{88}$ Jenia Iotcheva Turner, 'The Expressive Dimension of EU Criminal Law' (2012) 60 Am J Comp L 555. Although an alternative perspective would be that it is precisely because of the existence of a Union competence that the abolition of the double criminality rule is justified. See further chapter 5 .

${ }^{89}$ Ibid 572.

${ }^{90}$ Ibid 571.

${ }^{91}$ Framework Decision 2008/913/JHA on combating certain forms and expressions of racism and xenophobia by means of criminal law [2008] OJ L 328/55 preamble point (1).

${ }^{92}$ Turner (n 88) 572.

${ }^{93}$ Ibid 572.
} 
Similar points can be made in relation to the Framework Decision to Combat Terrorism (FDTC). ${ }^{94}$ Enacted following the attacks on New York of 11 September 2011, the FDCT (alongside various other measures) ${ }^{95}$ is a reaction to a radically altered global environment involving a renewed affirmation of the principles of democracy and human rights and a rejection of violence as a means of political communication. The values of 'human dignity, liberty, equality and solidarity, respect for human rights and fundamental freedoms', alongside the principle of democracy are clear articulated in the preamble as values of the Union and its Member States as is the assertion that 'terrorism constitutes one the most serious violations of those principles'. ${ }^{96}$ Its vague terms and inclusion of optional clauses point to its limited effectiveness as a harmonising tool and its use as a basis for cross-border cooperation is deemed superfluous. In terms of harmonisation what the FDCT does achieve is to introduce the so-called subjective element of terrorism. The objective acts that constitute terrorists acts were largely already criminalised under national law. What the Framework Decision does (in contradistinction to other international instruments) is render these specifically terrorist offences by virtue of the aim with which they are carried out; the subjective element. The purpose of the Framework Decision is therefore to articulate and alter the culpable dimension of the act; objectively it is the same act as other crimes but is rendered more culpable because it is carried out with a specific aim. In practice, what this has achieved is to apply a 'pejorative' label to certain acts, justifying further political and legal action by the Union and the Member States. As put by Murphy: '[ $t]$ he framework decision claims to approximate Member States' criminal law and provide the basis for cooperation and prevention. In reality it serves a less distinct and less distinguished purpose. It provides a legal mechanism by which to stigmatise a wide range of groups and individuals. Once labelled as 'terrorist' they become the subject of coercive powers. ${ }^{97}$

Finally, attention should be drawn to a number of instruments that have been adopted that appear to display a particular concern with vulnerable individuals. EU criminal law appears to be particularly motivated by a desire to protect weak or vulnerable members of society and instruments adopted to achieve this appear to go well beyond minimal harmonisation measures. The Directive on the Sexual Exploitation of Children is a remarkable piece of

\footnotetext{
${ }^{94}$ Framework Decision on combating terrorism [2002] OJ L 164/3 preamble point (1) which speaks of 'human dignity, liberty, equality and solidarity...the principle of democracy and the principles of the rule of law...'

95 Murphy (n 41) ch 3.

${ }^{96}$ Framework Decision on combating terrorism [2002] OJ L 164/3 preamble points (1) and (2).

${ }^{97}$ Murphy (n 41) 82.
} 
legislation and is notable for its breadth, comprehensiveness and its value laden language. ${ }^{98}$ It offers a marked contrast to other harmonisation instruments, in particular the Framework Decisions, which tended to be terse and minimal in nature. ${ }^{99}$ Alongside the elements of various offences, ${ }^{100}$ it lays down penalties, regulates certain defences available, ${ }^{101}$ limitation periods, ${ }^{102}$ territorial jurisdiction rules, ${ }^{103}$ reporting requirements ${ }^{104}$ and measures for the subsequent treatment of offenders both in terms of their rehabilitation but also criminal record and disqualification from various activities. ${ }^{105}$ In its application and in particular in aggravating sanctions for particularly vulnerable victims and for crimes that take place in the context of a relationship of responsibility ${ }^{106}$ it has a clear expressive and communicative function, articulating a particular judgment about the how to classify, not simply the harm, but the culpability and wrongfulness of particular acts. There is little or no attempt to justify the measure on the basis of a disparity between the legislation of Member States or the need to secure enhanced judicial cooperation and certainly no attempt to justify the comprehensive nature of the harmonisation effort on these grounds. There is no attempt to justify the replacement of the Framework Decision by the Directive. The sole reason for the new, much more comprehensive Directive is the question-begging assertion that 'serious criminal offences such as the sexual exploitation of children and child pornography require a comprehensive approach. ${ }^{, 107}$ While this is certainly true, it does not justify action by the European Union. Rather its depth, comprehensiveness and inclusion of key choices regarding the normative assessment and appropriate response to the phenomenon of the sexual exploitation of children can only be said to manifest a desire to appropriate a particular policy area, one that deals with particularly vulnerable individuals, and to express and give voice to a condemnation at a supranational level. ${ }^{108}$ According to the proposal the

\footnotetext{
98 Directive 2011/93/EU on combating the sexual abuse and sexual exploitation of children and child pornography, and replacing Council Framework Decision 2004/68/JHA [2011] OJ L 355/1.

${ }_{99}$ Indicating perhaps the shape of things to come in the new post-Lisbon era in which directives adopted under the ordinary legislative procedure have replaced Framework Decisions adopted following a rule of unanimity.

${ }^{100}$ Directive on the Exploitation of Children arts 3-5.

${ }^{101}$ Ibid art 8 relating to consensual activity.

102 Ibid art 15.

${ }^{103}$ Ibid art 17.

${ }^{104}$ Ibid art 16.

${ }^{105}$ Ibid arts 10 and 24.

${ }^{106}$ Ibid art 9. Alongside the usual aggravating circumstances such as recidivism.

${ }^{107}$ Ibid preamble point (6).

${ }^{108}$ Note this concern with children is not limited to this particular piece of legislation. Children often appear as the victims in cases involving criminal law in EU law. See Case C-348/09 PI v Oberbürgermeisterin der Stadt Remscheid EU:C:2012:300 and Case C-400/12 Secretary for State for the Home Department $v$ MG EU:C:2014:9. The European Union has been particularly active in recent years in developing children's rights and child protection measures. See Eleanor Drywood and Helen Stalford, 'Coming of Age? Children's Rights in the European Union' (2009) 46 CML Rev 143.
} 
legislation is aimed at combating acts that undermine 'the core values of modern society relating to the special protection of children' and are justified by the fact that '[n]ational legislation covers some of these problems, to varying degrees. However, it is not strong or consistent enough to provide a vigorous social response to this disturbing phenomenon'. ${ }^{109}$ The justification for Union action is simply the fact that in the judgement of the Union legislature, or at least the proposing institution within that legislature, these are particularly serious wrongs and Member States do not do enough to identify and punish them as such.

The Directive on the sexual exploitation of children is one example of the European Union intervening in a comprehensive fashion in order to criminalise harm to a particularly vulnerable class of individuals. Other examples of this concern with vulnerable victims can be seen in the Directive on Combating Human Trafficking. ${ }^{110}$ The Directive demonstrates a particular concern with the victims of human trafficking, mandating specific measures to ensure their protection in any investigation and proceedings ${ }^{111}$ and general assistance. ${ }^{112}$ Again, especially vulnerable victims, especially children are protected ${ }^{113}$ and again, crimes against particularly vulnerable victims are to attract aggravated sanctions. ${ }^{114}$ A similar concern with vulnerable individuals can be seen in the Victims' Rights Directive. ${ }^{115}$ Aside from a measure that is generally aimed at a vulnerable group of individuals, the Victims' Rights Directive has specific provision for particularly vulnerable individuals, ${ }^{116}$ especially children. ${ }^{117}$ It would appear that the European Union through various instruments has shown a particular concern for vulnerable groups of individuals and especially vulnerable victims of crime, either generally or through an intense interest in the protection of children. Through

\footnotetext{
109 Proposal for a Directive on combating the sexual abuse, sexual exploitation of children and child pornography repealing Framework Decision 2004/38/JHA COM(2010)94 final 2.

${ }_{110}$ Directive 2011/36/EU on preventing and combating trafficking in human beings and protecting its victims and replacing Council Framework Decision 2002/629/JHA [2011] OJ L 101/1.

${ }^{111}$ Ibid art 12 .

${ }^{112}$ Ibid art 11.

${ }^{113}$ Ibid arts 13-16.

${ }^{114}$ Ibid art 4(2)(a).

115 Interestingly for Moore moral outrage based on sympathy with victims is one of the justifications for the morality of a retributive approach to punishment; 'such revulsion [at particularly heinous crimes] is the only tolerable response to serious wrong-doing'. See Moore (n 26) 144. Similarly for Duff and Marshall it is through the suffering of fellow members of the community (ie citizens) that individual harms become public wrongs. See Duff and Marshall (n 3).

${ }^{116}$ Directive 2012/29/EU establishing minimum standards on the rights, support and proction of victims of crime and replacing Council Framework Decision 2001/220/JHA [2012] OJ L 315/57 arts 22-23 designating such persons as those with 'specific protection needs.'

${ }^{117}$ Ibid art 24.
} 
its measures in this field it appears to be taking a principled stance and articulating a set of values it believes are, or should be, central to the identity of the European Union.

\section{Supranational Wrongs and Transnational Processes}

But perhaps to focus on the function of supranational approximation and harmonisation measures adopted by the Union as expressing an autonomous normative judgment at a supranational level is to miss an important role that this competence plays in the Union. The supranational competence to criminalise behaviour, as hinted above in the discussion of its ancillary nature, should be placed in the broader context of criminal law in the EU. It is in the interaction with national criminal law and transnational processes and by framing national criminal law that supranational criminal law reveals one of its major purposes. This is particularly relevant for the competence under Article 83(1) TFEU, the so-called 'Eurocrimes', the ancillary nature of which has already been noted above. The absence of a capacity to create criminal liability or to communicate the wrongful character of an action directly to individuals is therefore not necessary. EU criminal law, in order to perform its function of complementing national law and providing a common supranational framework for the choices made at national level, does not and indeed should not have these characteristics. This use of supranational criminal law, as a means of endorsing national criminal law and facilitating transnational processes is evident actions by both the legislature and the Court.

Weyembergh points out the relationship between double criminality and approximation of criminal law; approximation will result in a situation where the double criminality rule is automatically met. ${ }^{118}$ As we have seen in chapter 5 , the abolition of the double criminality rule is premised on a shared conception of wrongs, that shared conception is assumed in the case of the list of 32 crimes for core crimes but also for crimes for which the Union has a approximating competence under Article 83(1) TFEU. By firstly attributing competence to the Union and then by enacting legislation, the Member States as drafters of the Treaty and as legislators in Council, ${ }^{119}$ have explicitly endorsed a certain shared vision of certain wrongful actions, particularly those that operate on a transnational level. This shared

\footnotetext{
118 Weyembergh (n 12), 158. Hence Turner's accusation that the Framework Decision on Xenophobia and Racism is unnecessary partially because of the abolition of double criminality in the EAW FD perhaps misunderstands the relationship between double criminality and approximation; it is because of approximation that the abolition of the rule is then justified. Turner (n 88) 571-572.

${ }^{119}$ And it must be remembered that any extension to the list of thirty two crimes is by unanimity in Council.
} 
conception of certain wrongs is then used to facilitate the operation of mutual recognition instruments and in particular the abolition of double criminality.

Another, and certainly not inevitable, use of the supranational criminal law is by the Court in the area of social integration. As we have seen in both $T_{s}$ akouridis ${ }^{120}$ and $P I^{121}$ the Court has used legislation adopted at a Union level to endorse and validate the choices made by Member States in exercising their prerogatives under the public policy exception. In the eyes of the Union, this conduct is similarly considered wrongful. This Union-level condemnation is now communicated to the individual concerned, albeit mediated by national criminal. It also serves to justify the notion that the expulsion of the Union citizen is not simply a national process but amounts to a breach of a Union law duty of citizenship with Union law consequences.

\section{Conclusion}

All law is expressive to some extent and embodies an exercise in communal valuation. The criminal law is perhaps particularly explicit in this regard, identifying as it does wrongful conduct, communicated to the individual through a process of trial and judgment, often by peers, and the serving of a 'penance' in (aptly termed) penitentiaries. It therefore has an especially pertinent expressive function in articulating and communicating the community's values to its individual members.

EU criminal law is clearly limited in its capacity to articulate public wrongs. This is a function of its limited and attributed competence and the manner in which it is exercised. In its attributed nature it is by necessity limited to certain core areas, predefined by Member States on the one hand and by the action of the Union in other areas on the other. Moreover, its criminal competence does not even appear to have been created with an expressive function in mind. It is seen as ancillary and regulatory or functional. It is linked to either other criminal law measures, such as mutual recognition, other goals of the Union, such as free movement, or other policies and harmonisation measures of the Union. It is similarly limited in its ability to communicate disapproval or condemnation on the part of the supranational community. It is multi-levelled and requires transposition. Importantly, this necessarily excludes the ability to impose criminal liability, framed in terms of the direct

\footnotetext{
${ }^{120}$ Case C-145/09 Land Baden-Wurttemberg v Panagiotis Tsakouridis EU:C:2010:708, [2010] ECR I-11979.

${ }^{121} P I(\mathrm{n} 108)$.
} 
effect of directives and the principle of legality and revealing an important limitation on the part of the Union. Finally, it lacks the important institutional context for the communication of public wrongs in individual cases. The symbolism of the criminal law is intimately bound up with its institutional processes, a symbolism that the Union lacks. EU criminal law is therefore extremely limited in its ability to articulate and communicate public wrongs to its individual citizens on behalf of the supranational community.

However, it remains the case that for all its limitations the Union does enjoy an explicit criminal competence and one that necessarily carries with it an independent expressive and evaluative function linked to the capacity to articulate public wrongs. It is limited and intervenes only in specific instances. While obscured by the technical and functional manner in which EU criminal law is discussed and justified by commentators and the institutions, its mere enactment and the values used to guide the choices, imply a certain set of supranational public wrongs, albeit at times ill-defined and implicit. This can be seen in two areas, linked on the one hand to the supposedly regulatory function of the law and on the other to the ancillary approximation competence contained in Article 83(1) TFEU. In employing the criminal law, EU law is implicitly classifying certain goods as European public goods, which engage a European public interest, violation of which constitutes not only material damage but a wrong to the European community. Thus the environment, the internal market, the financial system and the 'area of freedom, security and justice' itself, can be viewed in this manner. The precise utility of the approximation measures adopted under the now Article 83(1) TFEU in facilitating cross-border cooperation remains doubtful in a number of cases. Frequently, their main purpose appears to be to articulate a certain set of values or political principles on the part of the Union. This is particularly the case for Racism or Xenophobic crimes and the 'stigmatising' function of the framework decision on combating terrorism.

Indeed, it is the interaction with national norms and in transnational processes that the approximating competence of the Union under Article 83(1) TFEU, reveals an important role in endorsing national criminal law. Both the legislature and the court have used supranational criminal law in this fashion. The legislature in using these instruments to justify a shared conception in national law of these wrongful conducts in the abolition of double criminality in mutual recognition instruments in the area of free movement; the Court in using these instruments to endorse national choices under the public policy exception in the area of social integration. Both use supranational criminal law as a means of framing 
national criminal law and as a means of contributing to transnational processes, be they free movement and the creation of a single area of justice or social integration. Both ultimately reveal the multi-levelled and composite nature of the Union as a political community.

Criminal law articulates public wrongs, a fact which points to another feature of the criminal law that has been stressed by commentators and indeed judicial authorities; the link between collective identity and the expressive dimension of the criminal law. Without necessarily subscribing to the extreme version of ontological identification between the moral code of a community and the community itself, ${ }^{122}$ it is the case that the political community is only a community through the relations it establishes between its constituent members, expressed by its norms and formally by its laws. Choice is a means of affirming identity, a fact as true in law as in other dimensions of human action. ${ }^{123}$ The criminal law as a set of laws is more normative than most, implying explicit valuations and viewing them as rules of imperative public conduct guiding behaviour between individuals. As an expression of social values, it can be said to some extent perform a constituent function for the political community, binding individuals together through shared conceptions of wrongfulness and playing a role in its self-determination. As put by the Bundesverfassungsgericht: '[b]y criminal law, a legal community gives itself a code of conduct that is anchored in its values and whose violation according to the shared convictions on law, is regarded as so grievous and unacceptable for social co-existence in the community that it requires punishment. ${ }^{124}$ The European Union's criminal law competence is certainly limited in its ability to make choices about 'shared convictions' and to communicate those choices directly to individuals. Nonetheless by necessity it does just that in a number of cases and if legislation like the Directive on the Sexual Exploitation of Children is any indication, will do so in an increasing manner in the future. Moreover, in its choices it interacts with the choices made by national political communities, reflecting and endorsing national criminal law. Mirroring the EU as a political

\footnotetext{
${ }^{122}$ See the characterization of Lord Devlin's position by Hart in Hart (n 2) $51:$ ' .... a society is identical with its morality as that is at any given moment of its history, so that a change in its morality is tantamount to the destruction of the society.'

${ }^{123}$ See the discussion of Somek speaking of the importance of choice for the purposes of collective selfdetermination in the context of cosmopolitanism: 'It is through choice that a subject constitutes itself into the cause of an end and thus creates its appearance in the social world', Alexander Somek, 'The Cosmopolitan Constitution' in Miguel-Poiares Maduro, Kaarlo Tuori and Suvi Sankari (eds), Transnational Law: Rethinking European Law and Legal Thinking (CUP 2014) 118. See also Sustein: '...the expression of the appropriate evaluative attitude should be understood as a human good, constitutive of desirable characteristics. By making certain choices and not others, people express various conceptions both of themselves and of others.' Sustein (n 87) 823.

${ }^{124}$ Re Ratification of the Treaty of Lisbon (Bundesverfassungsgericht) [2010] 3 CMLR 13 para 328.
} 
community generally, its criminal law competence and in particular its ability to articulate and communicate public wrongs is limited, multi-levelled and composite, restricted in scope and requiring mediation by national legal orders but providing a framework for transnational processes. 



\section{Conclusion}

\section{Union Citizenship, Criminal Law and the Restructuring of Community}

In Answering for Crime and other writings ${ }^{1}$ Duff has elaborated a novel and comprehensive theory of criminal law that allows us to view the criminal law in a new light. By approaching the criminal law from a structural perspective based on a relational conception of responsibility and citizenship and community, he has provided us with a theory of the criminal law that is both analytical or explanatory and normative. His theory is analytical in that it allows us to make sense of the main features of the criminal law; the types and sources of criminal wrongs, the trial, defences, excuses and punishment. It is normative in providing a basis for the legitimacy of restricting the liberty of individuals and of inflicting punishment.

Duff's main purpose is to provide an adequate theory of criminal law and in doing so he relies on the concepts of citizenship and political community. However, conversely, Duff's account of the criminal law can inform and enrich our understanding of citizenship. In particular it adds a new perspective to a status that in law is typically analysed in terms of rights and liberties, especially those related to migration issues, ${ }^{2}$ and political participation. ${ }^{3}$ It provides a specific context to explore notions of duties, values and community and how they relate to citizenship. Following Duff's account the criminal law is a basis for a set of duties that flow from the status of citizenship; it is as fellow members of the political community that we are called to account for our wrongful action. Similarly, the basis of a

\footnotetext{
${ }^{1}$ RA Duff, Answering for Crime: Responsability and Liability in the Criminal Law (Hart 2007). See also RA Duff, Punishment, Communication and Community (OUP 2003), RA Duff, 'Law, Language and Community: Some Preconditions for Criminal Liability' (1998) 18 OJLS 189, RA Duff, 'Responsability, Citizenship and Criminal Law' in RA Duff and Stuart P Green (eds), Philosophical Foundations of Criminal Law (OUP 2011), RA Duff and SE Marshall, 'Criminalization and Sharing Wrongs' (1998) 11 CJLJ 7.

${ }^{2}$ In the case of the EU see in particular Dora Kostakopoulou, Citizenship, Identity and Immigration in the European Union; Between Past and Future (Manchester UP 2001). For a US based example see Linda Bosniak, The Citizen and the Alien: Dilemas of Contemporary Membership (Princeton UP 2006).

${ }^{3}$ See for example Jo Shaw, The Transformation of Citizenship in the European Union: Electoral rights and the restructuring of political space (CUP 2007). There is a rich literature on the political theory of Union citizenship that has significant relevance for legal studies. See especially the work of JHH Weiler, in particular Joseph Weiler, 'To be a European Citizen: Eros and Civilisation' in Joseph Weiler (ed), The Constitution of Europe (CUP 1999) and Habermas ex Jurgen Habermas, 'Citizenship and National Identity: Some reflections on the Future of Europe' in Ronald Beiner (ed), Theorizing Citizenship (SUNY Press 1995).
} 
wrong is the concept of a public wrong. It is variable and context specific and is rooted in the common understandings and values of the particular community. The criminal law therefore has an expressive quality, giving voice and meaning to certain norms of the community. Finally, through the institution of the criminal law the community is manifested in a very real way and directly relates to the individual as a collective. It is a public wrong; a wrong that concerns the community. The individual is called to account before the community through prosecution and trial in the name of 'the people'. The criminal law can therefore add a new perspective on citizenship, bringing a more value-infused, dutyorientated and community situated notion of citizenship to the fore.

The present study is an attempt to bring this perspective to bear on Union citizenship. This is particularly appropriate for a number of reasons. Firstly, it is a timely exercise; both Union citizenship and in particular the role of the Union in criminal law matters has seen rapid growth over the past two decades. Secondly, these two areas have been increasingly associated in the policy language and rhetoric of the Union institutions; the activity of the EU in criminal law is increasingly phrased in terms of security, a public good that is then 'offered' to Union citizens. ${ }^{4}$ Thirdly, an observation that occasionally surfaces in relation to Union citizenship is the lack of duties associated with the status, ${ }^{5}$ despite the Treaty's assertion to the contrary. ${ }^{6}$ This study argues that there are in fact duties associated with Union citizenship and that at least some of them can be found in the criminal law. Fourthly, another complaint levelled at Union citizenship is its rootless, liberal conception of the individual, devoid of a meaningful sense of community and norms. ${ }^{7}$ While not denying that some truth may lie behind these sentiments, this study argues that the concept of community and norms may in fact be present in Union law, in the area of criminal law.

\section{Complementing Union Citizenship}

\footnotetext{
${ }^{4}$ See especially The Stockholm Programme: An Open and Secure Europe Serving and Protecting Citizens [2010] OJ C 115/01 but rhetorical associations can also be discerned in earlier institutional statements. See Stephen Coutts, 'Citizenship and the Area of Freedom, Security and Justice' in Diego Acosta Arcarazo and Cian Murphy (eds), EU Security and Justice Law (Hart 2014).

${ }^{5}$ Dmitry Kochenov, 'EU Citizenship without Duties' (2014) 20 ELJ 482.

${ }^{6}$ 'Citizens of the Union shall enjoy the rights and be subject to the duties provided for in the Treaties', art 20(2) TFEU.

${ }^{7}$ See Michelle Everson, 'The Legacy of the Market Citizen' in Jo Shaw and Gillian More (eds), New Legal Dynamics of European Union (Claredon Press 1995) and more recently Michelle Everson, 'A Very Cosmopolitan Citizenship: But who Pays the Price?' in Michael Dougan, Niamh Níc Shuibhne and Eleanor Spaventa (eds), Empowerment and Disempowerment of the European Citizen (Hart 2012).
} 
Citizenship is a status that carries with it rights and duties and is located within a political community. ${ }^{8}$ The treatment of the criminal law in Union law contributes to all three aspects of Union citizenship.

\section{Rights}

While the focus of this work has been how norms expressed in the criminal law, both national and supranational, can contribute towards the imposition of certain duties on Union citizens, a consideration of the interaction of Union citizenship and criminal law does reveal some new rights associated with Union citizenship and how existing rights are strengthened and reinforced. ${ }^{9}$

Rights associated with the social integration and with the free movement of Union citizens are extended and reinforced in the context of criminal law. While the criminal law has been used to restrict Union citizens' residence rights in host Member States, certain aspects of criminal law, in particular the goal of rehabilitation has led to the further inclusion of Union citizens under certain circumstances. Thus the concept of rehabilitation has bolstered the right to equal treatment enjoyed by Union citizen in the context of the serving of sentences, both under the European Arrest Warrant Framework Decision (EAW FD) ${ }^{10}$ and the Framework Decision on the Mutual Recognition of Custodial Sentences. ${ }^{11}$ Secondly, the right to free movement is clearly and directly reinforced by the operation of the transnational ne bis in idem principle located in Article 54 CISA. The interpretation of the Court of Justice has principally, if not exclusively, been focused on maximising the free movement of individuals and reducing burdens and its interpretative choices, imposing strict mutual recognition of the original Member State's laws and developing a rule based on facts rather than crimes, have contributed a great deal to this effort. There is a parallel to be drawn between the manner in which a single civil status, such as a legal name, is created and

\footnotetext{
${ }^{8}$ For the different components of citizenship see Rainer Bauböck, 'Recombinant Citizenship' (Vienna) [1999] 67 Political Science WP Series, Institute for Advanced Studies, Vienna /Institut fur Höhere Studien, Wien.

${ }^{9}$ Aside from the general consideration that criminal law is a law that imposes duties on citizens in an effort to secure greater liberty rights for all. See Etienne Picard, 'La Fonction de l'Ordre Public dans l'Ordre Juridique' in Marie-Joëlle Redor (ed), L'ordre public: Ordre public ou ordres publics? Ordre public et droits fondamentaux (Bruylant 2001).

${ }^{10}$ Council Framework Decision 2002/584/JHA on the European arrest warrant and the surrender procedures between Member States (EAW FD) [2002] OJ L 190/1.

${ }^{11}$ Framework Decision 2008/909/JHA on the application of the principle of mutual recognition to judgements in criminal matters imposing custodial sentences or measures involving deprivation of liberty for the purposes of their enforcement in the European Union [2008] OJ L 327/27.
} 
rendered portable throughout the Union and the manner in which a status under national criminal law is similarly rendered applicable Union-wide.

Criminal law has also given the Union the opportunity to develop a set of supranational fundamental rights and procedural rights. Civil rights and fundamental rights are closely linked with the historic development of national citizenship. ${ }^{12}$ Additionally, in both their selection and the manner in which they are elaborated and applied, fundamental rights express the norms and political values of a political community. ${ }^{13}$ The development of a ne bis in idem principle, while primarily orientated at securing free movement, is nonetheless an important safeguard for the individual faced with the community's sanctioning powers and is one clear example of a supranational fundamental right. ${ }^{14}$ More generally, through the imposition of a common space of movement and the consequential setting aside of national fundamental rights guarantees in certain areas, the Union has been obliged to further develop its own set of fundamental rights. ${ }^{15}$ Finally, the necessity to secure 'mutual trust' has resulted in a (perhaps belated) process of rolling out a pan-European set of procedural rights, which, while limited and reliant on national procedures, do form the nucleus of European criminal procedural rights, a development no doubt remarkable to many. ${ }^{16}$

\section{Duties}

\footnotetext{
${ }^{12}$ See T.H. Marshall, Citizenship and Social Class (Robert Moore ed, Pluto Press 1950).

${ }^{13}$ See ex Cass Sustein, 'Incommensurability and Valuation in Law' (1994) 92 Mich L Rev 779, 802 ff speaking of the US First Amendment relating to the right to free speech.

${ }^{14}$ Indeed as pointed out in Chapter 6, there is convergence between the supranational and the transnational application of the principle under the rubric of Article 50 CFR. See Case C-261/09 Gaetano Mantello EU:C:2010:683, [2010] ECR I-11477 for its application in the context of the EAW FD and Case C-617/10 Åklagaren v Hans Akerberg Fransson EU:C:2013:280 for a supranational application.

${ }^{15}$ See Case C-396/11 Ciprian Vasile Radu EU:C:2013:39 and Case C-399/11 Stefano Melloni v Ministerio Fiscal EU:C:2013:107 both of which considered the operation of the EAW FD in light of the Charter of Fundamental Rights. It is notable that in the case of Melloni what was at stake was the operation of an amendment to the EAW FD which had effectively harmonised national conceptions of the right to a fair trial in the context of in absentia trials ie Council Framework Decision 2009/299/JHA amending Framework Decisions 2002/584/JHA, 2005/214/JHA, 2006/783/JHA, 2008/909/JHA and 2008/947/JHA, thereby enhancing the procedural rights of persons and fostering the application of the principle of mutual recognition to decisions rendered in the absence of the person concerned at the trial [2009] OJ L 81/24.

${ }^{16}$ This study has only dealt in passing with the concept of victims' rights, a new area for many Member States that points to a more fundamental change in the structure of criminal justice systems and one that the Union appears to be at the forefront of championing. See Directive 2012/29/EU establishing minimum standards on the rights, support and proction of victims of crime and replacing Council Framework Decision 2001/220/JHA [2012] OJ L 315/57 and Directive 2004/80/EC relating to compensation to crime victimes [2004] OJ L 261/1. For a general account of victims in the criminal process see Lucia Zedner, Criminal Justice (OUP 2004) $143 \mathrm{ff}$.
} 
When the question is considered, Union citizenship is generally considered bereft of duties. ${ }^{17}$ It is certainly true that only rights figure in the list contained in Article 21 TFEU. Nonetheless, one of the arguments of this thesis is that duties of Union citizenship can be located in criminal law and operate in all three areas of Union citizenship: social integration; free movement or autonomy and the supranational.

Firstly, through linking integration, crime and the status of the criminal offender in the host Member State and placing them in a communitarian account of both integration and crime, the Court of Justice has imposed a duty of respect for the norms of host societies on individual Union citizens as a condition for their continued enjoyment of membership in that community. This has occurred both in suspending rights of free movement and residence through the exercise of the public policy exception and in acquiring rights through the treatment of periods of imprisonment on the acquisition of rights under the Citizenship Directive. ${ }^{18}$ And while the object of such a duty of respect, in terms of values and norms, are provided by national law, the duty itself, it is suggested, is one that is imposed by Union law as an element of Union citizenship.

However, the concept of duties of Union citizenship through criminal law goes beyond the dimension of social integration of Union citizens but is also found in the concept of a free area of movement. It is suggested that a duty to respect the laws of other Member States exists also in the area of justice and is represented by the system of shared enforcement established by the EAW FD in particular. Both of these developments - rights of free movement and the area of justice - are linked by the notion of a single space or area occupied by Union citizens and with reference to which wrongs are enforced. Free movement has established a relationship with various Member States carrying with it rights. That relationship also entails responsibilities, which likewise are enforced transnational through a Union-wide system of enforcement.

Finally, the Union can be said to establish a number of duties at a supranational level, imposed on Union citizens. Here however, it should be pointed out that, aside from its limited and ancillary scope, in the multi-levelled context of the European Union legal

\footnotetext{
${ }_{17}^{17}$ Dmitry Kochenov, 'EU Citizenship without Duties' (2014) 20 ELJ 482.

${ }^{18}$ Directive 2004/38/EC on the right of citizens of the Union and their family members to move and reside freely within the territory of the Member States (Citizenship Directive) [2004] OJ L 158/77.
} 
system, the capacity of the Union to directly bind individuals is distinctly limited. As Berlusconi $^{19}$ in particular indicates, Union law cannot directly impose criminal liability on individuals and does not enjoy the quality of legality in the criminal law sense of being a validly adopted and binding act imposing criminal obligations on individuals. However, it is suggested that an important role for supranational criminal law is in justifying the use of national criminal law in a transnational setting. It therefore indirectly affects individuals through endorsing national criminal law in the restriction of Union citizens' rights or in facilitating transnational enforcement of national criminal law.

\section{Values}

Finally, a word should be said regarding values. Values and norms are central to the identity of a particular political community, particularly one that is not modelled on a thick concept of the nation ${ }^{20}$ and can form an important aspect of the concept of belonging, which is frequently considered a constituent element of citizenship. ${ }^{21}$ The Union was originally designed as a technocratic institution, albeit one with a political vocation, and its values have frequently seemed distant and/or ill-formed. ${ }^{22}$ This thesis argues that regardless of what one may think concerning the desirability of the particular values and normative choices made in the context of EU criminal law, ${ }^{23}$ the fact remains that one of the principle functions of criminal law is to express certain norms and that one of the principle functions of punishment is to communicate the public condemnation for breach of those norms. While indirect and often phrased in terms of instrumental or technical goals of compliance, EU criminal law does have the capacity to express certain normative choices on behalf of the Union as a whole, either in designating certain goods, often those associated with market institutions, as public goods, harm to which constitutes a wrong against the Union as a whole or in more select areas expressing certain values and norms adopted by the Union as guiding

\footnotetext{
19 Joined Cases C-387/02, C-391/02 and C-403/02 Criminal Proceedings against Silvio Berlusconi, Sergio Adelchi and Marcello Dull'Utri et al (Berlusconi) EU:C:2005:270, [2005] ECR I-3565.

${ }^{20}$ For a developed account and possible application to the European Union see Jurgen Habermas, 'The European Nation-State: On the Past and Future of Sovereignty and Citizenship' in Jurgen Habermas (ed), The Inclusion of the Other (MIT Press 1998).

${ }^{21}$ Shaw (n 3) 19.

${ }^{22}$ See for example Andrew T Williams, 'Taking Values Seriously: Towards a Philosophy of EU Law' (2009) 29 OJLS 549.

${ }^{23}$ EU criminal law has, until recently, been heavily criticised for a security-orientated focus that compromised fundamental rights see ex Sionaidh Douglas-Scott, 'The EU's Area of Freedom, Security and Justice: A Lack of Fundamental Rights, Mutual Trust and Democracy?' (2008-2009) 11 CYEL 53 and Estella Baker, 'The European Union's "Area of Freedom, Security and (Criminal) Justice" Ten Years On’ [2009] Crim LR 833.
} 
principles in criminalising certain conduct. More importantly perhaps is the endorsement function of supranational criminal law and its validation of national criminal law and the application of national criminal law in transnational settings. The cases of $P I^{24}$ and $T_{\text {sakouridis }}{ }^{25}$ are most striking in this regard but a similar operation be seen in the certain of the thirty two categories for which double criminality is typically abolished. ${ }^{26}$

\section{The Restructuring of Political Community in the European Union}

\section{Between National, Transnational and Supranational}

Duff's account of the criminal law is intimately linked with the notion of community. Starting from the premise that criminal law is public law, he identifies a significant role for the political community in explaining and justifying criminal law. It is therefore a communitarian account of both criminal law and of citizenship. ${ }^{27}$ Crimes are public wrongs, wrongs that concern the public. There must therefore be a public capable of being concerned. At the same time it is the norms and values of the community collectively that determine the content of the non-derogable norms of conduct that comprise the criminal law. ${ }^{28}$ Similarly, while many acts that result in crimes might directly be harms or wrongs against individuals, crimes themselves are wrongs against the public, they are shared wrongs experienced vicariously by the community at large via the membership of the victim. Criminal law therefore necessarily presupposes a public, a community and is a legal context within which the relationship of the individual citizen to that community is played out. Viewing citizenship through the lens of the criminal law can therefore reveal certain aspects of the broader community.

Much like the Union itself, the community that emerges from this study on the interaction between criminal law and Union citizenship is not simple or clear-cut but plays out in a complex interaction of the national, transnational and supranational in what is ultimately a

\footnotetext{
${ }^{24}$ Case C-348/09 PI v Oberbürgermeisterin der Stadt Remscheid EU:C:2012:300.

${ }^{25}$ Case C-145/09 Land Baden-Wurttemberg v Panagiotis Tsakouridis EU:C:2010:708, [2010] ECR I-11979.

26 Anne Weyembergh, 'The Functions of Approximation of Penal Legislation within the European Union' (2005) 12 MJ 149.

${ }^{27}$ While noting that a clean-cut distinction between the two is not particularly plausible. See Duff, Punishment, Communication and Community (n 1) ch 2.

${ }^{28}$ Hence the association of criminal law with public order see Agnes Cerf, 'Ordre Public, Droit Pénal et Droits Fondamentaux' in Marie-Joëlle Redor (ed), L'ordre public: Ordre public ou ordres publics? Ordre public et droits fondamentaux (Bruylant 2001).
} 
composite polity, a 'community of communities'. ${ }^{29}$ To look for the emergence of a complete, distinct European supranational community through top-down efforts at harmonisation and integration is to look in the wrong place. Perhaps surprisingly, it is not the operation of a supranational competence of criminalisation that is the main engine behind the emergence of a supranational community. Rather, such an entity emerges in a more organic fashion through the transnational processes triggered by free movement and social integration and their interaction with the criminal law. Supranational norms certainly play a role, but are limited and ancillary. Of more immediate relevance is the manner in which they reinforce transnational processes, confirming and endorsing national criminal law as they do so.

\section{The Primacy of National Communities}

While recent times have seen a rapid growth in the role of the Union in criminal law, it remains an area of law tied to national sovereignty and largely in the hands of national legislators. This picture of the national community as the primary locus of the articulation, application and experiencing of crimes is similarly visible in instances where criminal law interacts with Union citizens.

Crimes as wrongs are primarily articulated at a national level. The determination of what conduct should be subject to criminalisation takes place at a national level. The Union's competence to criminalise through approximation measures is limited in scope by its functional nature in the context of Article 83(2) TFEU and the closed list contained in Article 83(1) TFEU. Union law cannot directly create crimes but must rely on the mediating actions of Member States and only national criminal law enjoys the quality of legality. The vast majority of substantive criminal law, including the core crimes known as mala in se, remains in the hands of the Member States, a situation that is unlikely to change in the near future.

A similar privileging of the national is seen in transnational contexts. It is the fundamental interests and values of the host society that determine the content of public policy in expulsion cases. The element of national choice has been underlined by the Court of Justice for whom public policy and public security represent the fundamental interests of (the national) society. A similar privileging of the national community is identifiable in the

\footnotetext{
${ }^{29}$ Dora Kostakopoulou, 'European Citizenship: Writing the Future' (2007) 13 ELJ 623, 628.
} 
system for allocating individuals to particular Member States for the purposes of imprisonment. The principle of social integration only supplements, it does not replace, the principle of nationality. At the same time both the EAW FD and Article 54 CISA concern the mutual recognition of national crimes and national judgments, defined solely by reference to the issuing Member State or Member State of final judgment.

Not only is the wrong articulated at a national level but the wrong is also experienced at a national level; it is the national community that experiences the wrong through the violation of its norms. Clearly, it is not the Union that holds individuals to account, arrests, prosecutes, tries and punishes individuals; all of these functions, so central to the criminal law and reflecting the response of the community that is wronged, are carried out by the institutions of the Member States. The recent controversy over the European Public Prosecutor's Office is testimony to the sensitivities of the matter, even in an area where the Union's institutional interest is most directly implicated, namely its own financial resources. The national nature of the experience of the wrong is most clearly evident the case of expulsion and acquisition of residence rights treated in chapter 4. Crimes are wrongs against the national community that justify the limitation of rights vis-à-vis that community. However, even in matters of mutual recognition certain features of the legal practice serve to highlight the continued national nature of the wrong. In the operation of the EAW FD, while the executing Member State contributes to the enforcement of the crime, ultimately the individual is returned and tried by the issuing Member State, the community that experienced the wrong. Similarly, Member States are reluctant to cede the right to punish wrongs they see themselves as having experienced, as is evidenced by the absence of binding rules for allocating jurisdiction and the explicit insistence on inviolability of the national right to prosecute in the Framework Decision on Coordinating Criminal Jurisdiction. ${ }^{30}$

\section{National Wrongs in Transnational Processes}

However, those national wrongs are located within transnational processes closely linked to the operation of Union citizenship. The Court has made use of national criminal law to regulate the status of individual Union citizens in host Member States leading to their greater inclusion and greater exclusion, and has used national criminal law to impose a transnational

\footnotetext{
${ }^{30}$ Framework Decision 2009/948/JHA on prevention and settlement of conflicts of exercise of jurisdiction in criminal proceedings [2009] OJ L 328/42.
} 
duty of respect. At the same time, national wrongs are now recognised and enforced transnationally. National criminal law now operates within a single 'area of justice' that corresponds to the area of movement offered Union citizens through rights of free movement; rights and responsibilities, generated from national law, are enjoyed with reference to a broader geographical space.

\section{Supranational Implications - Shared Rights, Shared Wrongs and Shared Punishment}

These transnational processes however, while respecting the essentially national nature of wrongs and the communities that experience them, necessarily engage Union law and give rise to a common framework or norms, wrongs and community.

Firstly, there is much evidence to suggest that the treatment of criminal law within EU law gives rise to a shared conception of wrong-doing and hence a shared moral framework under which citizens' duties towards each other within the broader community are evaluated. The EAW FD in its abolition of double criminality for certain core crimes presupposes a common characterisation of those acts as wrongful across the Union. Similarly, acts that form the object of an approximation competence by the Union are similarly presumed to be wrongful for all Member States. Under the operation of the public policy exception national criminal law and the wrongful characterisation they entail can be endorsed by Union law and the normative choices made by the supranational community. While the Union lacks any direct means of punishing and thus directly communicating its condemnation of individuals who breach certain norms, it may do so indirectly, not (only) through the implementation of substantive Union criminal law but also through endorsing national criminal law when it arises in transnational processes.

Not only is there a common supranational conception of certain wrongs but there is evidence that a community exists at a supranational level capable of experiencing those wrongs. ${ }^{31}$ The legitimacy of the EAW system as a shared system of enforcement may be seen as reflecting a shared experience of the wrong by the Union as a whole. This is even more evident is the operation of the ne bis in idem principle; once called to account for wrong-doing in one Member State, the wrong is expunged vis-à-vis all Member States, the implication being that

\footnotetext{
${ }^{31}$ See Robin Lööf, 'Defending Liberty and Structural Integrity: A social contractual analysis of criminal justice in the EU' (PhD thesis, Department of Law, European University Institute 2008).
} 
only one such wrong exists. Even the scheme adopted through the EAW FD and the Framework Decision on the Transfer of Custodial Sentences ${ }^{32}$ could be seen in this light; there is an embryonic shared system of punishment, allowing Member States to collectively communicate condemnation to the individual.

But note that those wrongs are experienced through the wrongs suffered by national communities. It is the wrong suffered by the national community that is enforced within the EAW system but the legitimacy of that system of shared enforcement is premised on the sharing of that wrong by the executing Member State and potentially by all Member States. Similarly, the individual is called to account before the national courts for a national wrong and that calling to account is valid Union-wide under Article 54 CISA. The paradox is that crime remains resolutely national and yet collectively the Member States participate in its enforcement and to recognise any subsequent calling to account for that crime. The answer it is submitted lies in the shared nature of the wrong. ${ }^{33}$ It is through wrongs done individual Member States that one wrongs the Union as a whole.

The result is a composite, multi-levelled polity that operates along both a transnational and or horizontal axis and a supranational or vertical axis. However, the connections between national and supranational communities and the relationship between transnational and supranational processes are more complex than this simply vertical-horizontal picture would suggest. National, transnational and supranational processes interact and reinforce each other. The national remains privileged but operates in transnational contexts, these transnational contexts are facilitated by a supranational criminal law which in turn endorses national normative choices. Meanwhile, the assumptions behind transnational systems of enforcement and recognition manifest a supranational community. It is through transnational processes that supranational rights, wrongs and ultimately a community emerge.

\footnotetext{
${ }^{32}$ Transfer of Custodial Sentences Framework Decision (n 11).

${ }^{33}$ Duff and Marshall (n 1).
} 



\title{
Table of Cases
}

\author{
EU Caselaw
}

- van Duyn v Home Office Case 41/74 EU:C:1974:133, [1974] ECR 1337

- Regina v Bouchereau Case 30/77 EU:C:1977:172, ECR [1977] 199

- Regina v Maurice Donald Henn and John Frederick Ernest Darby Case 34/79 EU:C:1979:295, [1979] ECR 3795

- Rewe-Zentral AG v Bundesmonopolverwaltung für Branntwein Case 120/78 EU:C:1979:42, [1979] ECR 649

- DM Levin v Staatssecretaris van Justitie Case 53/81 EU:C:1982:105, [1982] ECR 1035

- Adoui and Cornuaille v Belgium Joined Cases 115/81 and 116/81 EU:C:1982:183, [1982] ECR 1665

- Netherlands v Ann Florence Reed Case 59/85 EU:C:1986:157, [1986] ECR 1283

- $R$ H Kempf v Staatssecretaris van Justitie Case 139/85 EU:C:1986:223, [1986] ECR 1741

- Pretore di Salò Case 14/86 EU:C:1987:275, [1987] ECR 2545

- Commission v Greece (Greek Maize) Case 68/88 EU:C:1989:339, [1989] ECR 2965

- Christos Konstantinidis v Stadt Altensteig - Standesamt and Landratsamt Calw Ordnungsamt Case C-168/91 EU:C:1993:115, [1991] ECR I-1191

- Mario Vicente Micheletti and others v Delegación del Gobierno en Cantabria Case C-369/90 EU:C:1992:295, [1992] ECR I-4239

- The Queen v Immigration Appeal Tribunal and Surinder Singh Case C-370/90 EU:C:1992:296, [1992] ECR I-4265

- Bordessa and Ors Joined Cases C-358/93 and C-416/93 EU:C:1995:54, [1995] ECR I-361

- Reinhard Gebhard v Consiglio dell'Ordine degli Accoacti e Procuratori di Milano Case C-55/94 EU:C:1995:411, [1995] ECR I-4165

- Criminal proceedings against Sofia Skanavi and Konstantin Chryssanthakopoulos Case C-193/94 [1996] ECR I-929

- Commission $v$ French Republic (Spanish Strawberries) Case C-265/95 EU:C:1997:595, [1997] ECR I-6959

- Maria Martinez Sala and Freistaat Bayern Case C-85/96 EU:C:1998:217, [1998] ECR I-2694

- Criminal Proceedings against Donatella Calfa Case C-348/96 EU:C:1999:6, [1999] ECR I-11

- Mary Carpenter v Secretary of State for the Home Department Case C-60/00 EU:C:2002:434, [2002] ECR I-6279

- The Queen and Secretary of State for the Home Department, ex parte: Manjit Kaur Case C-192/99 EU:C:2001:106, [2001] ECR I-1252

- Rudy Grzelczyk v Centre public d'aide sociale d'Ottignies-Louvain-la-Neuve Case C184/99 EU:C:2001:458, [2001] ECR I-6193

- Baumbast and $R v$ Secretary of State for the Home Department Case C-413/99 EU:C:2002:493, [2002] ECR I-7091 
- Marie-Nathalie D'Hoop v Office national de l'emploi Case C-224/98 EU:C:2002:432, [2002] ECR I-6191

- Mouvement contre le racisme, l'antisémitisme et la xénophobie ASBL (MRAX) v Belgian State Case C-459/99 EU:C:2002:461, [2002] ECR I-6591

- Carlos Garcia Avello v Belgian State Case C-148/02 EU:C:2003:539, [2003] ECR I11613

- Criminal proceedings against Hüseyin Gözütok and Klaus Brügge Joined Cases C187/01 and C-385/01 EU:C:2003:87, [2003] ECR I-1345

- Secretary of State for the Home Department v Hacene Akrich Case C-109/01 EU:C:2003:491, [2003] ECR I-9607

- Collins v Secretary of State for Work and Pensions Case C-138/02 EU:C:2004:172, [2004] ECR I-2803

- Criminal Proceedings against X Case C-60/02 EU:C:2004:10, [2004] ECR I-651

- Georgios Ofanopoulous et al and Raffaele Oliveri v Land Baden-Würtemberg Joined Cases C-482/01 and C-493/01 [2004] ECR I-5257

- Heikki Antero Pusa v Osuuspankkien Keskinäinen Vakuutusyhtiö Case C-224/02 EU:C:2004:273, [2004] ECR I-5763

- Kunqian Catherine Zhu, Man Lavette Chen v Secretary of State for the Home Department, Case C-200/02 EU:C:2004:639, [2004] ECR I-9951

- Michel Trojani v Centre public d'aide sociale de Bruxelles (CPAS) Case C-456/02 EU:C:2004:488, [2004] ECR I-7573

- Omega Spielhallen- und Automatenaufstellungs-GmbH v Oberbürgermeisterin der Bundesstadt Bonn Case C-36/02 EU:C:2004:614, [2004] ECR I-9609

- Spain v UK Case C-145/04 EU:C:2006:543, [2004] ECR I-7902

- Commission v Council (Environmental Crimes) Case C-176/03 EU:C:2005:542, [2005] ECR I-7879

- Criminal proceedings against Filomeno Mario Miraglia Case C-469/03 EU:C:2005:156, [2005] ECR I-2009

- Criminal Proceedings against Maria Pupino Case C-105/03 EU:C:2005:386, [2005] ECR I-5309

- Criminal Proceedings against Silvio Berlusconi, Sergio Adelchi and Marcello Dull'Utri et al (Berlusconi) Joined Cases C-387/02, C-391/02 and C-403/02 EU:C:2005:270, [2005] ECR I-3565

- Egon Schempp v Finanzamt München V Case C-403/03 EU:C:2005:446, [2005] ECR I-6421

- The Queen (on the application of Dany Bidar) v London Borough v Ealing, Sec. of State for Education and Skills Case C-209/03 EU:C:2005:169, [2005] ECR I-2119

- Criminal proceedings against Guiseppe Francesco Gasparini and Others Case C467/04 EU:C:2006:610, [2006] ECR I-9199

- Criminal proceedings against Jürgen Kretzinger Case C-288/05 EU:C:2007:441, [2007] ECR I-6441

- Criminal proceedings against Leopold Henri Van Esbroeck Case C-436/04 EU:C:2006:165, [2006] ECR I-2333

- Eman and Sevinger $v$ College van Burgemeester en Wethouders van Den Haag Joined Cases C-300/04 EU:C:2006:545, [2006] ECR I-8055

- Jean Leon Van Straaten v Staat der Nederlanden and Republiek Italië Case C-150/05 EU:C:2006:614, [2006] ECR I-9327

- K. Tas-Hagen and R. A. Tas v Raadskamer WUBO van de Pensioen- en Uitkeringsraad Case C-192/05 EU:C:2006:676, [2006] ECR I-10451 
- Stefan Grunkin and Dorothee Regina Paul Case C-353/06 EU:C:2008:559, [2008] ECR I-7639

- Advocaten voor de Wereld VZW v Leden van de Ministerraad Case C-303/05 EU:C:2007:261, [2007] ECR I-3633

- Commission v Council (Ship Source Pollution) Case C-440/05 EU:C:2007:625, [2007] ECR I-9097

- Commission v Netherlands Case C-50/06 [2007] ECR I-04383

- Criminal proceedings against Norma Kraaijenbrink Case C-367/05 EU:C:2007:444, [2007] ECR I-6619

- Minister voor Vreemdelingenzaken en Integratie v R. N. G. Eind Case C-291/05 EU:C:2007:771, [2007] ECR I-10719

- Rhiannon Morgan v Bezirksregierung Köln and Iris Bucher v Landrat des Kreises Düren Joined Cases C-11/06 and C-12/06 EU:C:2007:626, [2007] ECR I-9161

- Criminal proceedings against Vladimir Turanský Case C-491/07 EU:C:2008:768, [2008] ECR I-11039

- Halina Nerkowska v Zakład Ubezpieczeń Spotecznych Oddział w Koszalinie Case C499/06 EU:C:2008:300 [2008] ECR I-3993

- Heinz Huber v Bundesrepublik Deutschland Case C-524/06 EU:C:2008:724, [2008] ECR I-9705

- Jacqueline Förster v IB-Groep Case C-158/07 EU:C:2008:630, [2008] ECR I-8507

- Klaus Bourquain Case C-297/07 EU:C:2008:708, [2008] ECR I-9425

- Metock $v$ Minister for Justince Equality and Law Reform Case C-127/08 EU:C:2008:449, [2008] ECR I-6241

- Proceedings concerning the execution of a European arrest warrant issued against Szymon Kozłowski Case C-66/08 EU:C:2008:437, [2008] ECR I - 6041

- Athanasios Vatsouras, Josif Koupatantze v Arbeitsgemeinschaft (ARGE) Nürnberg 900 Joined Cases C-22/08 and C-23/08 EU:C:2009:344, ECR [2009] I-4585

- Dominic Wolzenburg Case C-123/08 EU:C:2009:616, [2009] ECR I-9621

- Nural Ziebell v Land Baden-Wurtenmburg Case C-371/08 EU:C:2011:809

- Spector Photo Group v Commissie voor het Bank-, Financie en Assuranctiewezen (CBFA) Case C-45/08 EU:C:2009:806, [2009] ECR I-12073

- Gaetano Mantello Case C-261/09 EU:C:2010:683, [2010] ECR I-11477

- IB Case C-306/09 EU:C:2010:626, [2010] ECR I-10341

- Ilonka Sayn-Wittgenstein v Landeshauptmann von Wein Case C-208/09 EU:C:2010:806, [2010] ECR I-13693

- Janko Rottmann v Freistaat Bayern Case C-135/08 EU:C:2010:104, [2010] ECR I1449

- Secretary of State for Work and Pensions v Taous Lassal Case C-162/09 EU:C:2010:592, [2010] ECR I-9217

- Gerardo Ruiz Zambrano v Office national de l'emploi (ONEm) Case C-34/09 EU:C:2011:124, [2011] ECR I-1177

- Land Baden-Wurttemberg v Panagiotis Tsakouridis Case C-145/09 EU:C:2010:708, [2010] ECR I-11979

- Lucy Stewart v Secretary of State for Work and Pensions Case C-503/09 EU:C:2011:500, [2011] ECR I-6497

- Malgožata Runevič-Vardyn and Łukasz Pawel Wardyn v Vilniaus miesto savivaldybès administracija and Others Case C-391/09 EU:C:2011:291, [2011] ECR I-3787

- Murat Dereci and Others v Bundesministerium für Inneres Case C-256/11 EU:C:2011:734, [2011] ECR I-11315 
- NS v Secretary of State for the Home Dept Joined Cases C-411/10 and C-493/10 EU:C:2011:865, [2011] ECR I-13905

- Secretary of State for the Home Department $v$ Maria Dias Case C-325/09 EU:C:2011:498, [2011] ECR I-6387

- Shirley McCarthy v Secretary of State for the Home Department Case C-434/09 EU:C:2011:277, [2011] ECR I-3375

- Tomasz Ziolkowski \& Barbara Szeja \& Oths v Land Berlin Joined Cases C-424/10 and C-425/10 EU:C:2011:866, [2011] ECR I-14035

- Melvin West Case C-192/12 PPU EU:C:2012:404

- PI v Oberbürgermeisterin der Stadt Remscheid Case C-348/09 EU:C:2012:300

- Proceedings concerning the execution of a European arrest warrant issued against João Pedro Lopes Da Silva Jorge Case C-42/11 EU:C:2012:517

- Åklagaren v Hans Åkerberg Fransson Case C-617/10 EU:C:2013:280

- Alokpa et al v Minstre du Travail de l'Emploi et de l'Immigration Case C-86/12 EU:C:2013:645

- Ciprian Vasile Radu Case C-396/11 EU:C:2013:39

- Jeremy F v Premier ministre Case C-168/13PPU EU:C:2013:358

- Shamso Abdullahi v Bundesasylamt Case C-394/12 EU:C:2013:813

- Stefano Melloni v Ministerio Fiscal Case C-399/11 EU:C:2013:107

- Ymeraga $v$ Minstre du Travail, de l'Emploi et de l'Immigration Case C-87/12 EU:C:2013:291

- Criminal proceedings against Zoran Spasic Case C-129/14 PPU EU:C:2014:586

- Elisabeta Dano \& Florin Dano v Jobcenter Leipzig Case C-333/13 EU:C:2014:2358

- $\quad M$ Case C-398/12 EU:C:2014:1057

- Nnamdi Onuekwere v Secretary of State for the Home Department Case C-378/12 EU:C:2014:13

- \& B v Minister voor Immigratie, Integratie en Asiel Case C-456/12 EU:C:2014:135

- Opinion 2/13 Opinion 2/13 EU:C:2014:2454

- $\quad$ v Minister voor Immigratie, Integratie en Asiel Case C-457/12 EU:C:2014:136

- Secretary for State for the Home Department v MG Case C-400/12 EU:C:2014:9

- Minister van Buitenlandse Zaken v K and A Case C-153/14 EU:C:2015:453

- Z, Zh \& O v Staatssecretaris van Veiligheid en Justie Case C-554/13 (Opinion of AG Sharpson, 12 February 2015)

\section{EFTA Court Caselaw}

- Jan Anfinn Wahl v the Icelandic State E-15/12 [2013] EFTA Ct Rep 534

\section{ECHR Caselaw}

- Soering $v$ United Kingdom Series A no 161

- Boultif v Switzerland ECHR 2001-IX

- Hirst $v$ United Kingdom (2006) 42 EHRR 41

- Maslov v Austria App no 1683/03 (ECtHR, 23 June 2008)

- Zolotukhin v Russia App no 14939/03 (ECtHR, 10 February 2009)

- Tarakhel $v$ Switzerland App no 29217/12 (ECHR 4 November 2014) 


\section{National Caselaw}

- United States $v$ Lanza 260 US 377, 43 SCt 141

- Heath v Alabama 474 US 82

- $R v$ Brown [1994] 1 AC 212

- Attorney General of the Republic of Cyprus v Konstantinou [2007] 3 CMLR 42

- Re Constitutionality of German Law Implementing the Framework Decision on a European Arrest Warrant [2006] 1 CMLR 16

- Re Constitutionality of Framework Decision on a European Arrest Warrant (Czech Constitutional Court) [2007] 3 CMLR 24

- Re Ratification of the Treaty of Lisbon (Bundesverfassungsgericht) [2010] 3 CMLR 13

- Attorney General v O'Gara [2012] IEHC 179

- Minister for Justice, Equality and Law Reform v Bailey [2012] IESC 16

- Minister for Justice and Equality v Jaroslaw Ostrowski [2013] IESC 


\title{
Table of Legislation
}

\author{
EU Legislation
}

- Directive 64/221/EEC on the co-ordination of speacial measurs concernign the movement and residence of foreign nationals which are justified on grounds of public policy, public security or public health [1964] OJ L 117

- Regulation 1612/68/EEC on freedom of movement for workers within the Community [1968] OJ L 257/2

- Act concerning the election of the representatives of the Assembly by direct universal suffrage [1976] OJ L 278/5

- Directive 90/364/EEC on the right of residence [1990] OJ L 180/26

- Directive 90/365/EEC on the right of residence for employees and self-employed persons who have ceased their occupational activity [1990] OJ L 180/28

- Treaty on European Union, together with the complete text of the Treaty Establishing the European Community [1992] OJ C 224/1

- Directive 93/96/EEC on the right of residence for students [1993] OJ L 317/59

- Directive 93/109/EC laying down detailed arrangements for the exercise of the right to vote and stand as a candidate in elections to the European Parliament for citizens of the Union residing in a Member State of which they are not nationals (Uniform Election Procedure) [1993] OJ L 329/34

- Directive 94/80/EC laying down detailed arrangements for the exercise of the right to vote and to stand as a candidate in munipal elections by citizens of the Union residing in a Member State of which they are not naionals [1994] OJ L 368/38 as amended by Council Directive 96/30/EC [1996] OJ L 122/14

- Directive 98/5/EC to facilitate practice of the profession of lawyer on a permanent basis in a Member State other than that in which the qualification was obtained [1998] OJ L 77/36

- Convention on the Implementation of the Schengen Agreement, Ch 3

- Decision 2000/365/EC concerning the request of the United Kingdom of Great Britain and Northern Ireland to take part in some of the provisions of the Schengen acquis [2000] OJ L 131/43

- Decision concerning Ireland's request to take part in some of the provisions of the Schengen acquis [2002] OJ L 64/20

- Framework Decision 2002/584/JHA on the European arrest warrant and the surrender procedures between Member States (EAW FD) [2002] OJ L 190/1

- Framework Decision on combating terrorism [2002] OJ L 164/3

- Framework Decision 2003/568/JHA on combating corruption in the private sector [2003] OJ L 192/54

- Regulation 343/2003/EC establishing the criteria and mechanisms for determining the Member State responsible for examining an asylum application lodged in one of the Member States by a third-country national [2003] OJ L50/1

- Regulation 2201/2003/EC concerning jurisdiction and the recognition and enforcement of judgments in matrimonial matters and the matters of parental responsibility [2003] OJ L 338/23 
- Directive 2004/38/EC on the right of citizens of the Union and their family members to move and reside freely within the territory of the Member States (Citizenship Directive) [2004] OJ L 158/77

- Directive 2004/80/EC relating to compensation to crime victimes [2004] OJ L 261/1

- Framework Decision 2004/757/JHA laying down minimum provisions on the constituent elements of criminal acts and penalties in the field of illicit drug trafficking [2004] OJ L 335/8

- Framework Decision 2008/909/JHA on the application of the principle of mutual recognition to judgements in criminal matters imposing custodial sentences or measures involving deprivation of liberty for the purposes of their enforcement in the European Union [2008] OJ L 327/27

- Framework Decision 2008/913/JHA on combating certain forms and expressions of racism and xenophobia by means of criminal law [2008] OJ L 328/55

- Framework Decision 2008/978/JHA on the European Evidence Warrant for the pupose of obtaining objects, documents and data for use in proceedings in criminal matters [2008] OJ L 350/72

- Framework Decision 2009/299/JHA amending Framework Decisions 2002/584/JHA, 2005/214/JHA, 2006/783/JHA, 2008/909/JHA and 2008/947/JHA, thereby enhancing the procedural rights of persons and fostering the application of the principle of mutual recognition to decisions rendered in the absence of the person concerned at the trial [2009] OJ L 81/24

- Framework Decision 2009/948/JHA on prevention and settlement of conflicts of exercise of jurisdiction in criminal proceedings [2009] OJ L 328/42

- Directive 2010/64/EU on the right to interpretation and translation in criminal proceedings [2010] OJ L 280/1

- Directive 2011/36/EU on preventing and combating trafficking in human beings and protecting its victims and replacing Council Framework Decision 2002/629/JHA [2011] OJ L 101/1

- Directive 2011/93/EU on combating the sexual abuse and sexual exploitation of children and child pornography, and replacing Council Framework Decision 2004/68/JHA [2011] OJ L 355/1

- Regulation 211/2011/EU on the citizens' initiative [2011] OJ L65/1

- Regulation 492/11/EU on freedom of movement for workers within the Union [2011] OJ L 141/1

- Regulation 492/2011/EU on freedom of movement for workers within the Union (codification) [2011] OJ L141/1

- Directive 2012/29/EU establishing minimum standards on the rights, support and proction of victims of crime and replacing Council Framework Decision 2001/220/JHA [2012] OJ L 315/57

- Directive 2012/13/EU on the right to information in criminal proceedings [2013] OJ L $142 / 1$

- Directive 2013/38/EU on the right of access to a lawyer in criminal proceedings and in European arrest warrnat proceedings, and on the right to have a third party informed upon deprivation of liberty and to communicate with third persons and with consular authorities while deprived of liberty [2013] OJ L 294/1

- Regulation 604/2013 establishing the criteria and mechanisms for determining the Member State responsible for examining an application for international protection lodged in one of the Member States by a third-country national or a stateless person (recast) [2013] OJ L180/31 
- Directive 2014/41/EU regarding the European Investigation Order in criminal matters [2014] OJ L 130/1

- Directive 2014/57/EU on criminal sanctions for market abuse (Market Abuse Directive) [2014] OJ L 173/179

- Directive 2014/62/EU on the proctection of the euro and other currencies against counterfeiting by criminal law and replacing Framework Decision 2000/383/JHA (Counterfeiting Directive) [2014] OJ L 151/1

\section{National Legislation}

- European Arrest Warrant Act 2003

\section{Non-Leglislative Documents}

- Conclusions of the Presidency Edinburgh, December 12, 1992 Annex 3 Unilateral Declaration of Denmark

- Proposal for a Council Framework Decision on the European arrest warrant and the surrender procedures between the Member States COM(2001) 522 final [2001] OJ C $332 \mathrm{E} / 18$

- Initiative of the Hellenic Republic with a view to adopting a Council Framework Decision concerning the application of the ne bis in idem principle [2003] OJ C $100 / 24$

- The Hague Programme: Strengthening Freedom, Security and Justice in the European Union [2005] OJ C 53/1

- Resolution of the Council on a Roadmap for strengthening procedural rights of suspected or accused persons in criminal proceedings [2009] OJ C 295/1

- The Stockholm Programme: An Open and Secure Europe Serving and Protecting Citizens [2010] OJ C 115/01

- Proposal for a Directive on combating the sexual abuse, sexual exploitation of children and child pornography repealing Framework Decision 2004/38/JHA $\operatorname{COM}(2010) 94$ final

- Proposal for a Directive on the fight against fraud to the Union's financial interests by means of criminal law $\operatorname{COM}(2012) 363$ final

- Proposal for a Council Regulation on the establishment of the European Public Prosecutor's Office COM(2013) 534 final

- Commission E, Communication on the Special Measures concerning the Movement and Residence of Citizens of the Union which are Justified on Grounds of Public Policy, Public Security or Public Health COM(1999) 372 final, 1999

- Green Paper on the approximation, mutual recognition and enforcement of criminal sanctions in the European Union COM(2004) 334 final Brussels, 2004

- Report from the Commission based on Article 34 of the Council Framework Decision of 13 June 2002 on the European arrest warrant and the surrender procedures between Member States COM(2006) 8 final (2006)

- Report from the Commission to the European Parliament and the Council on the application of Directive 2004/38/EC on the right of citizens of the Union and their 
family members to move and reside freely within the territory of the Member States $\operatorname{COM}(2008) 840$ final, 2008

- Communication from the Commission to the European Parliament and the Council on guidance for better transposition and application of Directive 2004/38/EC on the right of citizens of the Union and their family members to move and reside freely within the territory of the Member States COM(2009) 313 final, 2009

—, Report from the Commission on the implementation since 2007 of the Council Framework Decision of 13 June 2002 on the European arrest warrant and the surrender procedures between Member States COM(2011) 175 final, 2011

—, Towards an EU Criminal Policy: Ensuring the effective implementation of EU policies through criminal law $\mathrm{COM(2011)} 573$ final, 2011

- Green Paper on Conflicts of Jurisdiction and the Principle of ne bis in idem in Criminal

Proceedings

COM(2005)

696

final,

2005 



\section{Bibliography}

- Acosta Arcarazo D, The Long-Term Residence Status as a Subsidiary Form of EU Ctizenship: An Analysis of Directive 2003/109 vol 23 (Martinus Nijhoff 2011)

- Alegre S and Leaf M, 'Mutual Recognition in European Judicial Cooperation: A Step too Far too Soon? Case Study - the European Arrest Warrant' (2004) 10 ELJ 200

- Anagnostaruas G, 'Enhanced Protection of EU Nationals against expulsion and the concept of internal public security: Comment on P.I.' (2012) 37 EL Rev 627

- Anderson B, Imagined Communities (2nd edn, Verso 2006)

- Arnull A, The European Union and its Court of Justice (OUP 2006)

- Ashworth A, Principles of Criminal Law (2 edn, Claredon Press 1995)

- Azoulai L, 'La loi et le règlement vus du droit communautaire' (2006) 19 Cahiers du Conseil constitutional

- Azoulai L, 'La citoyenneté européenne, un statut d'intégration sociale' in CohenJonathan $\mathrm{G}$ and others (eds), Chemins d'Europe: Mélanges en l'honneur de Jean Paul Jacqué (Dalloz 2010)

_-, "Euro-Bonds" The Ruiz Zambrano judgment or the Real Invention of EU Citizenship' (2011) 3 Perspectives on Federalism

_-, 'L'autonomie de l'individu européen et la question du statut' EUI Working Papers LAW 2013/14

- Baker E, 'Taking European Criminal Law Seriously' (1998) Crim LR 361

— , 'Criminal Jurisdiction, the Public Dimension to 'Effective Protection' and the Construction of Community-Citizen Relations' (2001) 4 CYEL 25

—, 'The European Union's "Area of Freedom, Security and (Criminal) Justice" Ten Years On' [2009] Crim LR 833

— , 'Governing through Crime - the Case of the European Union' (2010) 7 European Journal of Criminology 187

- Barrett G, 'Introduction - A New Improved Formula? The Treaty of Lisbon and National Parliaments ' in Barrett G (ed), National Parliaments and the European Union: the Consitutional Challenge for the Oireachtas and other member state legislatures (Clarus Press 2008)

- Bauböck R, Transnational Citizenship: Migration and Rights in International Migration (Edward Elgar 1994)

—, 'Recombinant Citizenship' (Vienna) [1999] 67 Political Science WP Series, Institute for Advanced Studies, Vienna /Institut fur Höhere Studien, Wien

- Bauböck R and Joppke C, How Liberal are Citizenship Tests? (EUI Working Papers RSCAS 2010/41, 2010)

- Beetham D, The Legitimation of Power (1 edn, Humanities Press Int 1991)

- Bellamy R, 'A Duty-Free Europe? What's Wrong with Kochenov's Account of EU Citizenship Rights' (2015) 21 ELJ 558

- Besselink L, 'The Parameters of Constitutional Conflicts after Melloni' (2014) 39 EL Rev 531

- Bobek M, 'The effects of EU law in the national legal systems' in Barnard C and Peers S (eds), European Union Law (OUP 2013)

- Boister N, 'Transnational Criminal Law?' (2003) 14 EJIL 953 
- Bosniak L, The Citizen and the Alien: Dilemas of Contemporary Membership (Princeton UP 2006)

- Bouza Garcia L, 'The European Citizen's Initiative: A New Institution for Empowering Europe's Citizens?' in Dougan M, Níc Shuibhne N and Spaventa E (eds), Empowerment and Disempowerment of the European Citizen (Hart 2012)

- Brubaker R, Citizenship and Nationhood in France and Germany (Harvard UP 1992)

- Carrera (ed) S, 'The Nexus between Immigration, Integration and Citizenship in the EU' (Immigration, Integration and Citizenship, CEPS, Brussels, 25 January 2006)

- Castillo M and Chemain R, 'La Réserve d'Ordre Public en Droit Communautaire' in Redor M-J (ed), L'ordre public: Ordre public ou ordres publics? Ordre public et droits fondamentaux (Bruylant 2001)

- Cerf A, 'Ordre Public, Droit Pénal et Droits Fondamentaux' in Redor M-J (ed), L'ordre public: Ordre public ou ordres publics? Ordre public et droits fondamentaux (Bruylant 2001)

- Chalmers D, Davies G and Monti G, European Union Law (3 edn, CUP 2014)

- Chehtman A, 'Citizenshp v Territory: Explaining the Scope of the Criminal Law' (2010) 13 New Crim L Rev 427

- Coppel J and O'Neill A, 'The European Court of Justice: Taking Rights Seriously?' (1992) 29 CML Rev 669

- Costello C, 'Metock: Free Movement and "Normal Family Life" in the Union' 46 CML Rev 587

- 'Courting Access to Asylum in Europe: Recent Supranational Jurisprudence Explored' (2012) 12 HRL Rev 287

- Coutts S, 'The Lisbon Treaty and the Area of Freedom, Security and Justice as an Area of Legal Integration ' (2011) 7 Croatian Yearbook of European Law and Policy 69

—, 'Citizenship and the Area of Freedom, Security and Justice' in Acosta Arcarazo D and Murphy C (eds), EU Security and Justice Law (Hart 2014)

_, 'Union Citizenship as Probationary Citizenship: Onuekwere' (2015) $52 \mathrm{CML}$ Rev 531

- Davies A, 'Radu - A Case of Failed Dialogue' (eutopia law Blog, 5 February 2013) <http://eutopialaw.com/2013/02/05/radu-a-case-of-failed-dialogue/\#more-1755> accessed 14 February 2013

- Davies G, 'Any Place I Hang my Hat?' or: Residence is the New Nationality' (2005) 11 ELJ 43

- Dawes A and Lynskey O, 'The Ever-Longer Arm of EC Law: The Extension of Community Competence into the Field of Criminal Law' (2008) 45 CML Rev 131

- de Búrca G, 'The Road Not Taken: The European Union as a Global Human Rights Actor' (2011) 105 AJIL 649

—_, 'The Quest for Legitimacy in the European Union' (1996) 59 MLR 349

- de Witte F, 'Sex, Drugs and EU Law: The Recognition of Moral and Ethical Diversity in EU Law' (2013) 50 CML Rev 1545

- Díez-Picazo LM, 'What does it mean to be a state within the European Union?' [2002] Riv Ital Dir Pubbl Communitario 651

- Dougan M, 'The Spatial Restructuring of National Welfare States within the European Union: the contribution of Union Citizenship and the relevance of the Treaty of Lisbon.' in Neergaard U, Nielson R and Rosebury L (eds), Integrating Welfare Function into EU Law: From Rome to Lisbon (DJOF Publishing 2009) 
- 'From Velvet Glove to the Iron Fist: Criminal Sanctions for the Enforcement of Union Law' in Cremona M (ed), Compliance and the Enforcement of EU Law (OUP 2012)

- 'The Bubble that Burst: Exploring the Legitimacy of the Case Law on the Free Movement of Union Citizens' in Adams M and others (eds), Judging Europe's Judges: The Legitimacy of the Case law of the European Court of Justice (Hart 2013)

_ - 'The Constitutional Dimension to the case law on Union Citizenship' (2006) 31 EL Rev 613

_ - 'What are we to Make of the Citizens' Initiative' (2011) 48 CML Rev 1807

- Douglas-Scott S, 'The EU's Area of Freedom, Security and Justice: A Lack of Fundamental Rights, Mutual Trust and Democracy?' (2008-2009) 11 CYEL 53

- Drywood E and Stalford H, 'Coming of Age? Children's Rights in the European Union' (2009) 46 CML Rev 143

- Duff R, Theories of Criminal Law (The Stanford Encyclopedia of Philosophy (Summer 2013 Edition))

_-, Punishment, Communication and Community (OUP 2003)

_- Answering for Crime: Responsability and Liability in the Criminal Law (Hart 2007)

—, 'Responsability, Citizenship and Criminal Law' in Duff R and Green SP (eds), Philosophical Foundations of Criminal Law (OUP 2011)

_, 'Law, Language and Community: Some Preconditions for Criminal Liability' (1998) 18 OJLS 189

_-, 'Theorizing Criminal Law: A 25th Anniversary Essay' (2005) 25 OJLS 353

- Duff R and Marshall S, 'Criminalization and Sharing Wrongs' (1998) 11 CJLJ 7

- Durkheim E, The Division of Labour in Society (Simpson G tr, Collins-MacMillian 1933)

- Eleftheriadis P, 'Citizenship and Obligation' in Dickson J and Eleftheriadis P (eds), Philosophical Foundations of European Union Law (OUP 2012)

- Everson M, 'The Legacy of the Market Citizen' in Shaw J and More G (eds), New Legal Dynamics of European Union (Claredon Press 1995)

— ' 'A Very Cosmopolitan Citizenship: But who Pays the Price?' in Dougan M, Níc Shuibhne N and Spaventa E (eds), Empowerment and Disempowerment of the European Citizen (Hart 2012)

- Fahey E, EU Law in Ireland (Clarus Press 2010)

- Farmer L, 'Time and Space in Criminal Law' (2010) 13 New Crim L Rev 333

- Feinberg J, 'The Expressive Function of Punishment' (1965) 49 The Monist 397

—, The Moral Limits of the Criminal Law: Harm to Others, vol I (OUP 1984)

—, The Moral Limits of the Criminal Law: Offense to Others, vol III (OUP 1985)

—, The Moral Limits of the Criminal Law: Harm to Self, vol III (OUP 1986)

- The Moral Limits of the Criminal Law: Harmless Wrongdoing, vol IV (OUP 1988)

- Fletcher M, Lööf R and Gilmore B, EU Criminal Law and Justice (Edward Elgar 2008)

- Franssen V, 'National Parliaments issue yellow card against the European Public Prosecutor's Office' (European Law Blog, 4 November 2013) $<$ http://europeanlawblog.eu/?p=2025> accessed 20 July 2015

- Gardocki L, 'Double Criminality in Extradition Law' (1993) 27 Israel L Rev 288

- Gibbs AH, Constitutional Life and Europe's Area of Freedom, Security and Justice (Ashgate 2011) 
- Gough J, The Social Contract: A Critical Study of its Development (2 edn, Clarendon Press 1957)

- Habermas J, 'Human Rights and Popular Sovereignty: The Liberal and Republican Versions' (1994) 7 Ratio Juris 1

— ' 'Citizenship and National Identity: Some reflections on the Future of Europe' in Beiner R (ed), Theorizing Citizenship (SUNY Press 1995)

—, 'The European Nation-State: On the Past and Future of Sovereignty and Citizenship' in Habermas J (ed), The Inclusion of the Other (MIT Press 1998)

-, 'The Postnational Constellation and the Future of Democracy' in Habermas $\mathbf{J}$ (ed), The Postnational Constellation (Polity Press 2001)

- Hailbronner K, 'Union Citizenship and Access to Social Benefits' (2005) 42 CML Rev 1245

- Hailbronner K and Thym D, 'Case Note C-34/09: Zambrano v ONEm' (2011) 48 CMLRev 1253

- Hammar T, Democracy and the nation state: aliens, denizens and citizens in a world of international migration (Aldershot 1990)

- Hart H, Law, Liberty and Morality (OUP 1962) _-, 'Are there any Natural Rights?' (1955) 64 The Philosophical Review 175

- Hart HM, 'The Aims of Criminal Law' 23 LCP 401

- Harvey C, 'Promoting Insecurity: Public Order Explusion and the ECHR' in Guild E and Minderhoud P (eds), Security of Residence and Expulsion: Protection of Aliens in Europe (Kluwer International 2001)

- Herlin-Karnell E, The Constitutional Dimension of European Criminal Law (Hart 2012)

- _ - 'The Swedish Supreme Court and the European Arrest Warrant: Comment on the decision of 21 March 2007, surrending of Polish National (Ö 430-07)' [2007] Europarättsligtidskrift 885

- Hudson B, 'Punishing Monsters, Judging Aliens: Justice at the Borders of Community' (2006) 39 Austrialian and New Zealand J of Criminology 232

- Iliopoulou Penot A, 'The Transnational Character of Union Citizenship' in Dougan M, Níc Shuibhne N and Spaventa E (eds), The Empowerment and Disempowerment of the European Citizen (Hart 2012)

- Jacobs F, 'Citizenship of the European Union - A Legal Analysis' (2007) 13 ELJ 591

- Janssens C, The Principle of Mutual Recognition in EU Law (OUP 2013)

- Karydis G, 'L'ordre public dans l'ordre juridique communautaire: un concept à contenu variable' [2002] RTD eur 1

- Kaunert C, 'The Area of Freedom, Security and Justice: The Construction of a 'European Public Order' (2005) 14 European Security 459

- Kent Curtis M, No State Shall Abridge: The Fourteenth Amendment and the Bill of Rights (Duke UP 1987)

- Kesby A, The Right to have Rights: Citizenship, Humanity and International Law. (OUP 2012)

- Kessedjian C, 'Public Order in European Law' (2007-2008) 1 Erasmus Law Review 25

- Knowles D, Political Obligation: A Critical Introduction (Routledge 2010)

- Kochenov D, 'The Citizenship Paradigm' (2012-2013) 15 CYELS 197

— , 'EU Citizenship without Duties' (2014) 20 ELJ 482

- Komarek J, 'European Constitutionalism and the European Arrest Warrant: In Search of the Limits of "Contrapunctual Principles"' (2007) 44 CML Rev 9 
- Kornezov A, 'The Area of Freedom, Security and Justice in Light of the EU Accession to the ECHR - Is the Break-up inevitable?' (2012-2013) 15 CYELS 227

- Kostakopoulou D, Citizenship, Identity and Immigration in the European Union; Between Past and Future (Manchester UP 2001)

- ' 'The Area of Freedom, Security and Justice and the European Union's Constitutional Dialogue' in Barnard C (ed), The Fundamentals of EU Law Revisited, vol XVI/2 (OUP 2007)

—, 'Ideas, Norms and European Citizenship: Explaining Institutional Change' 68 MLR 233

_ , 'European Citizenship: Writing the Future' (2007) 13 ELJ 623

- Kuipers J-J, 'Cartesio and Grunkin Paul: Mutual Recognition as a Vested Rights Theory based on Party Autonomy in Private Law' 2 EJLS 66

- Lenaerts K, 'Constitutionalism and the Many Faces of Federalism' (1990) 38 Am J Comp L 205

- Lindahl H, 'Finding a place for freedom, security and justice: the European Union's claim to territorial unity' (2004) 29 EL Rev 461

- Loader I and Walker N, Civilising Security (CUP 2007)

- Lobkowicz Wd, 'L'Europe et la sécurité intérieure: Une elaboration par étapes' La Documentation Francaise, décembre 2001, No 5144-45

- Lööf R, 'Defending Liberty and Structural Integrity: A social contractual analysis of criminal justice in the EU' (PhD thesis, Department of Law, European University Institute 2008)

_ ' '54 CISA and the Principles of ne bis in idem' (2007) 15 Eur J Crime Crim L \& Crim Just 309

- Lyon-Caen G, 'La réserve d'ordre public en matiere de liberé d'etablissement et de libre circulation' (1966) RTD Eur 693

- MacCormick N, 'Law as Institutional Fact' 90 LQR 102 — , 'Reconstruction after Deconstruction: A Response to CLS' (1990) 10 OJLS 539

- Macklin A and Bauböck R, The Return of Banishment: Do the New Denationalisation Policies Weaken Citizenship? (EUI Working Papers, RSCAS 2015/14, 2015)

- Maduro M-P, 'So close and yet so far: the paradoxes of mutual recognition' (2007) 14 JEPP 814

- Magnette P, La Citoyennéte Européenne (Editions de l'Université de Bruxelles 1999) —, La Citoyenneté: Une Histoire de l'Idée de Participation Civique (Bruylant 2001)

- Marin L, 'A Spectre is Haunting Europe': European Citizenship in the Area of Freedom, Security and Justice ' (2011) 17 EPL 705

- Marshall TH, Citizenship and Social Class (Moore R ed, Pluto Press 1950)

- McAdams RH, The Expressive Powers of Law: Theories and Limits (Harvard UP 2015)

- Mendes J, 'Participation and the Role of Law After Lisbon: A Legal View on Article 11 TEU' (2011) 48 CML Rev 1849

- Mendéz AJ, 'European Citizenship after Martiníz Sala and Baumbast: Has European Law become More Human but Less Social?' in Poirias Maduro M and Azoulai L (eds), The Past and Future of EU Law (Hart 2010)

- Mill JS, On Liberty and Other Essays (first published 1859 OUP 1991)

- Mitsilegas V, EU Criminal Law (Hart 2009) - 'The Constitutional Implications of Mutual Recognition in Criminal Matters in the EU' (2006) 43 CML Rev 1277

- Monar J, 'The Area of Freedom, Security and Justice' in Bast J and von Bogdandy A (eds), Principles of European Constitutional Law (2 edn, Hart, Verlag CH Beck 2010) 
— , 'The Dynamics of Justice and Home Affairs: Laboratories, Driving Factors and Costs' (2001) 39 JCMS 747

- Moore M, Placing Blame: A Theory of Criminal Law (OUP 1997)

- Möstl M, 'Preconditions and Limits of Mutual Recognition' (2010) 47 CML Rev 405

- Murphy C, EU Counter-Terrorism Law: Pre-Emption and the Rule of Law (Hart 2012)

- Níc Shuibhne N, 'Derogating from the Free Movement of Persons. When can EU citizens be deported?' (2005-2006) 8 CYELS 187

- 'The Third Age of EU Citizenship' in Syrpis P (ed), The Juriciary, the Legislature and the EU Internal Market (CUP 2012)

_-, 'The Resilience of EU Market Citizenship' (2010) 47 CML Rev 1597

—, 'Seven Questions for Seven Paragraphs' (2011) 36 EL Rev 161

- Nicolaidis $\mathrm{K}$ and Shaffer G, 'Transnational Mutual Recognition Regimes: Governance without Global Government' (2005) 68 LCP 263

- Norrie A, Crime, Reason and History: A Critical Introduction to Criminal Law (1 edn, Weidenfeld \& Nicolson 1993)

- O'Brien C, 'I Trade, therefore I Am: Legal Personhood in the European Union' (2013) 50 CML Rev 1643

- O'Leary S, The Evolving Concept of Community Citizenship: From the Free Movement of Persons to Union Citizenship (Kluwer 1996)

—, 'The Past, Present and Future of the Purely Internal Rule in EU Law' in Dougan M, Níc Shuibhne N and Spaventa E (eds), Empowement and Disempowerment of the European Citizen (Hart 2012)

— - 'Putting flesh on the bones of European Union Citizenship' (1999) 24 EL Rev 68 Öberg J, 'Do we really need criminal sanctions for the enforcement of EU Law?' (2014) 5 NJECL 370

—, 'Limits to EU powers: A case study on individual criminal sanctions for the enforcement of EU Law' (PhD, European University Institute 2014)

- Olsen ED, 'Transnational European Citizenship: Tracing Conceptions of Citizenship in the European Integration Process' (PhD thesis, European University Institute, Florence 2008)

- Ouwekerk J, 'Criminal Justice beyond National Sovereignty. An Alternative Perspective on the Europeanisation of Criminal Law' (2015) 23 Eur J Crime Crim L \& Crim Just 11

- Peers S, 'The European Community's Criminal Law Competence: The Plot Thickens' (2008) 33 EL Rev 399

—, EU Justice and Home Affairs Law (3 edn, OUP 2011)

- 'The European Arrest Warrant: The Dilemas of Mutual Recognition, Human Rights and EU Citizenship' in Rosas A, Bot Y and Leits E (eds), The Court of Justice and the Construction of Europe: Analyses and Perspectives on Sixty Years of CaseLaw (Asser Press 2013)

— ' 'Justice and Home Affairs since the Treaty of Lisbon: A Fairy Tale Ending?' in Acosta Arcarazo D and Murphy C (eds), EU Security and Justice Law (Hart 2014)

_, 'Mutual Recognition and Crimial Law in the European Union: Has the Council got it wrong?' (2004) 41 CML Rev 5

- Picard E, 'La Fonction de l'Ordre Public dans l'Ordre Juridique' in Redor M-J (ed), L'ordre public: Ordre public ou ordres publics? Ordre public et droits fondamentaux (Bruylant 2001)

- Plachta M, '(Non-)Extradition of Nationals: A Neverending Story' (1999) 13 Emory Int'l L Rev 70 
_ , 'European Arrest Warrant: Revolution in Extradition?' (2003) 11 Eur J Crime Crim L \& Crim Just 178

- Plender R, 'An Incipient Form of European Citizenship' in Jacobs F (ed), European Law and the Individual (North-Holland Publishing Company 1976)

- Preuß U, 'Problems of a Concept of European Citizenship' (1995) 1 ELJ 267

- Rawls J, A Theory of Justice (Harvard UP 1971)

- Raynor P and Robinson G, Rehabilitation, Crime and Justice (Campling J ed, 1 edn, Palgrave Macmillan 2005)

- Reed Amar A, 'Double Jeopardy Law Made Simiple' (196-1997) 106 Yale LJ 1807

- Rock P, 'Sociological Theories of Crime' in Reiner R, Maguire M and Morgan R (eds), The Oxford Handbook of Criminology (5 edn, OUP 2012)

- Schiltz C, 'Akrich: A Clear Delimitation without Limits' (2005) 12 MJ 241

- Schnapper D, La Communauté des Citoyens: sur l'idée moderne de nation (Gallimard 1994)

- Schönberger C, 'European Citizenship as Federal Citizenship: Some Citizenship Lessons of Comparative Federalism' (2007) 19 Eur Rev Pub L 61

- Shaw J, The Transformation of Citizenship in the European Union: Electoral rights and the restructuring of political space (CUP 2007)

—, 'Citizenship of the Union - Towards Post-National Membership' Jean Monnet Working Papers 06/97 <http://centers.law.nyu.edu/jeanmonnet/archive/papers/97/9706-.html > accessed 22 July 2015

_, 'The Political Representation of Europe's Citizens: Developments' (2008) 4 EuConst 162

- Sigler JA, 'A History of Double Jeopardy' (1963) 7 Am J Legal Hist 283

- Simon P, 'The Criminalisation Power of the European Union after Lisbon and the Principle of Democratic Legitimacy' (2012) 3 NJECL 242

- Solanke I, 'HC and Sanneh - 'genuine enjoyment' does not include social welfare' (eutopia law, 20 December 2013) <http://eutopialaw.com/2013/12/20/hc-and-sannehgenuine-enjoyment-does-not-include-social-welfare/\#more-2216> accessed 28 January 2014

- Somek A, 'The Cosmopolitan Constitution' in Maduro M-P, Tuori K and Sankari S (eds), Transnational Law: Rethinking European Law and Legal Thinking (CUP 2014)

- Spaventa E, Free Movement of persons in the European Union: Barriers to Movement in their Constitutional Context (Kluwer Law International 2007)

_ - 'Case C-109/01 Secretary of State for the Home Department v H Akrich' (2005) 42 CML Rev 225

- Suominen A, 'Effectiveness and Functionality of Substantive EU Criminal Law' (2014) 5 NJECL 388

- Sustein C, 'Incommensurability and Valuation in Law' (1994) 92 Mich L Rev 779

- Thym D, 'The Elusive Limits of Solidarity: Residence Rights of and Social Benefits for Economically Inactive Union Citizens' (2014) 52 CML Rev 17

- Turner JI, 'The Expressive Dimension of EU Criminal Law' (2012) 60 Am J Comp L 555

- Twomey P, 'Construcuting a Secure Space: The Area of Freedom, Security and Justice' in O'Keefe D and Twomey P (eds), Legal Issues of the Amsterdam Treaty (Hart 1999)

- van Bockel B, The Ne Bis in Idem Principle in EU Law (Kluwer 2010)

- van den Wyngaert C and Stessens G, 'The International Non Bis in Idem Principle: Resoloving Some of the Unanswered Questions' (1999) 48 ICLQ 779 
- Van Dijk P, 'Protection of "Integrated" Aliens against Expulsion under the European Convention on Human Rights' in Guild E and Minderhoud P (eds), Security of Residence and Expulsion: Protection of Aliens in Europe (Kluwer International 2001)

- van Middelaar L, Passage to Europe: How a Continent became a Union (Waters L tr, Yale University Press 2013)

- Vervaele J, 'Annotation of Cases C-187/01 and C-385/01Gözütok and Brügge' (2004) 41 CML Rev 795

- Von Bogdandy A and others, 'Reverse Solange - Protecting the Essence of Fundamental Rights against EU Member States' (2012) 49 CML Rev 489

- Wagner E, 'The Integration of Schengen into the Framework of the European Union' (1998) 25 LIEI 1

- Walker N, 'Denizenship and Deterritorialization in the EU' LAW 2008 Oxford Journal of Legal Studies, No 4, 2005

_, 'The Idea of Constitutional Pluralism' [Blackwell Publishing on behalf of the Modern Law Review] 65 MLR 317

- Weiler J, 'To be a European Citizen: Eros and Civilisation' in Weiler J (ed), The Constitution of Europe (CUP 1999)

- , 'In the Face of Crisis: Input Legitimacy, Output Legitimacy and the Political Messianism of European Integration' (2012) 34 Journal of European Integration 825

- Weiner A, European Citizenship Practice (Westview Press 1998)

- Weyembergh A, 'The Functions of Approximation of Penal Legislation within the European Union' (2005) 12 MJ 149

- White RC, 'Conflicting Competences: Free Movement Rules and Immigration Laws' (2004) 29 EL Rev 385

- Williams AT, 'Taking Values Seriously: Towards a Philosophy of EU Law' (2009) 29 OJLS 549

- Wollenschläger F, 'A New Fundamental Freedom beyond Market Integration: Union Citizenship and its Dynamics for Shifting the Economic Paradigm of European Integration' (2011) 17 ELJ 1

- Zedner L, Criminal Justice (OUP 2004)

-, 'Is the Criminal Law Only for Citizens? A Problem at the Borders of Punishment' in Bosworth M and Franco Aas K (eds), The Borders of Punishment: Migration, Citizenship and Social Exclusion (OUP 2013) 